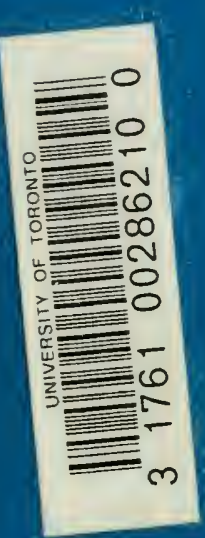








\section{Ld CIFISIS}

\section{AERIGOZA Y PECUARIA}





\section{LA CRISIS}

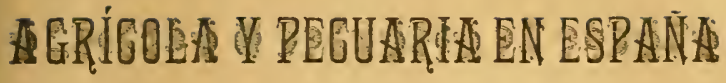

Y SUS

VERDADEROS REMEDIOS,

POR

D. Santiago martinez maroto

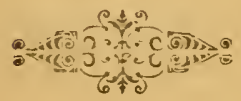

VALLADOLID:

Imprenta, Librería, Heliografía y Fotograbados de José Manuel de la Cuesta,

Cantarranas, $3 s$ y 0.

$$
1896
$$



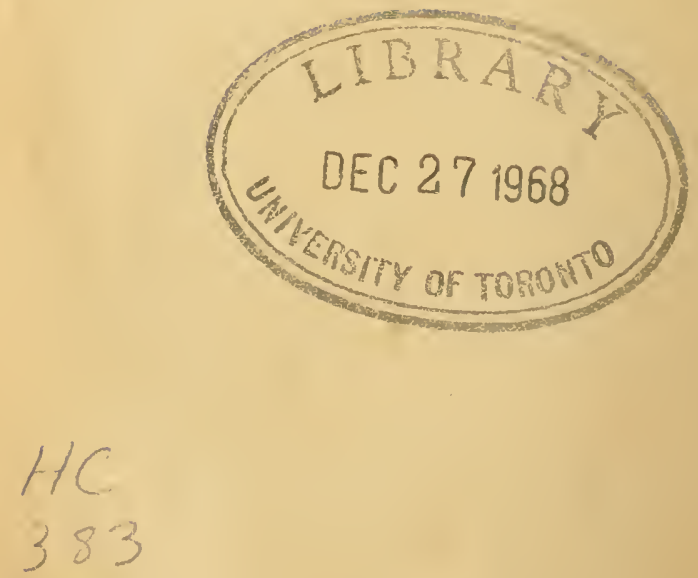

M 37 


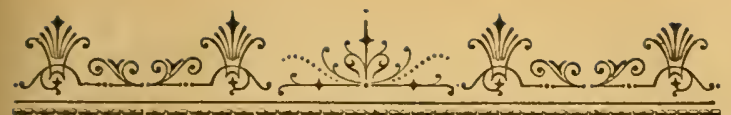

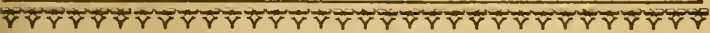

\section{INTRODUCCIÓN}

1. Causas de la crisis agraria.-Esta requiere medios eficaces y urgentes.

2. Deberes que la pátria impone à todos sus hijos.

La prolongada y tan pavorosa crisis porque atraviesa la riqueza agricola y pecuaria, exige imperiosamente la aplicación inmediata de los remedios más eficaces para conjurarla, si no se quiere consumar la completa ruina del más importante elemento de nues. tra producción nacional, á la vez que la del comercio, la industria, las ciencias y las artes; puesto que hoy todo depende de la agricultura, de esa ciencia de primer órden como la llamó Cicerón, fuente la más copiosa de riqueza y preciado venero de la prosperidad de los pueblos, como que sin ella no sería posible la vida. A tan importante fin, es necesario el concurso valioso ó el apoyo sincero, 
la cooperación más decidida y entusiasta de los Poderes públicos y de todos los buenos españoles.

La importancia trascendental que todos los pueblos civilizados conceden al cultivo de la tierra, es bien conecida y por mucho que á su protección y desarrollo consagren los Gobiernos, sus estudios, desvelos y trabajos, nunca será bastante, porque la agricultura es la base sólida de los Estados, verdadero secreto de la prosperidad y engrandecimiento de las naciones; elemento de la paz y el órden; columna firmísima sobre la que descansa el edificio social; lazo de unión entre los pueblos más recónditos y apartados del globo terráqueo, esperanza del porvenir, y cimiento firme de la regeneración y progreso de España.

La necesidad de fomentar con premura la producción agrícola, por todos está reconocida, y sin embargo de que ya no cabe esperar más, es muy poco lo que hacen los Gobiernos y las personas que por su mucha valía pueden aliviar los graves males que el pais lamenta.

Es general, y por desgracia muy justificado el clamoreo de los viticultores por la situación tan critica, excepcional y angustiosa en que se hallan colocados, sin poder dar 
salida á sus productos, ni caros ni baratos. por la escasa ó nula demanda á los mismos, asi como el de los labradores por ser los precios de los careales tan súmamente reducidos que no compensan siquiera lo que cuesta el producirlos. La ganadería antes tan rica y floreciente, hoy debido á las crecidas importaciones de carnes que por los medios frigorificos y antisépticos inundan los centros de consumo; á que los precios de las mismas carnes, como también de la leche, quesos, lanas y pieles son bastante reducidos, á las muchas enfermedades y desgracias de los ganados; ála escasez de pastos y á otras diversas circunstancias, es lo cierto que se halla en la actualidad, en muy visible decadencia y postración.

Todos sabemos que España es la nación de Europa y América en que más crecidas y desiguales son las contribuciones; que se tributa de una manera muy desproporcionada, ruinosa y altamente injusta; que hay, sí algunos pueblos en los que continúa oculta su riqueza, no obstante las disposiciones altamente plausible, dictadas para descubrirla; pero que también hay otros muchos obligados á contribuir por mayor cabida ó riqueza imponible que la que en realidad ex iste en sus respectivos términos municipales; 
que nuestros gobernantes tienen la idea equivocada de que el agricultor es el que más utilidades recibe por sus productos, por lo cual se acumulan casi exclusivamente sobre él todas las cargas y gravámenes; que en la distribución de los gastos se escatiman casi siempre los más necesarios y de verdadera utilidad pública, como son los del Ministerio de Fomento; que para simular economías se suprimen los cargos de empleados de menor categoria que son los que más trabajan y más reducido sueldo perciben, con lo cual no se consigue más que desatender los servicios públicos y alguna rebaja ridicula que, aun cuando no sea justicia, nada resuelve; que no se atienden quejas por justas que sean; que la Administración parece que muestra especial carácter en considerar al contribuyente como enemigo, procurando en todos los casos resolver las cuestiones, no á lo que aconseja la equidad y la justicia, sino en beneficio exclusiro del Estado, y que no se piensa más que en los ingresos, causando vejaciones sin cuento á los Ayuntamientos y contribuyentes; y sin embargo, éstos siempre pacíficos y resignados continuan dando pruebas de abnegación, patriotismo y sufrimiento, á pesar de que su bolsilio y su paciencia no son inagotables. 
Si algunos creen que España es una vaca que puede ordeñarse cuanto se quiera, llegará pronto el dia que de sus tetas no brote más que sangre, y seguidamente sobrevendrá una tisis galopante, y con ella la consunción y la muerte; y ningún Gobierno por árbitro y violento que sea, deberá cortar el árbol por la raiz para aprovechar sus frutos, sino recoger éstos con el mayor cuidado cuando se hallen en buena sazón, y cultivar después debidamente la planta para que pueda dar nuevos frutos en lo sucesivo; pues no es mejor Administración la que más dinero recauda, como no explota mejor sus fincas el agricultor que más las esquilma; y como tampoco es mejor pastor el que para utilizar el vellón de lana, en vez de esquilar las ovejas, las desuella.

La clase agrícola, se halla dispuesta á toda clase de sacrificios por la pátria, como lo está demostrando en la actualidad con motivo de la guerra de Cuba; pues los agricultores no necesitan estimulos de ningún género, y se apresuran á dar sus própios hijos y su dinero para sostener en aquel lejano y ardoroso país tropical, la integridad del Territorio y los derechos de España; dando á la vez ejemplo admirable de su acendrado patriotismo, y de que este hidalgo país, no es una 
nación decadente, sino de las grandes luchas, de los grandes entusiasmos y de las grandes energias; y como le dá el Ejército español de su inolvidable valor, intrepidez, arrojo y bravura por la causa de la bandera.

La asoladora guerra de la Isla de Cuba, es un motivo más para que se apliquen con la mayor premura los remedios que el angustioso estado de la clase agrícola demanda; y por la ley de la necesidad y aún por razón de egoismo, el Estado debe proteger con la mayor decisión los intereses de la agricultu$\mathrm{ra}$, a fin de que no se agote la fuente principal de nuestra riqueza pública; y para poder hacer frente con holgura á lo que las necesidades de la guerra y las circunstancias exijan, evitando al propio tiempo desastrosas consecuencias económicas.

Por lo tanto, el Gobierno debe preocuparse sériamente de la aflictiva y anómala situación de las clases productoras, y adoptar con urgencia las disposiciones conducentes para remediar, ó aliviar siquiera, los muchos y graves males que lamentan, y muy en particular hoy que la agricultura, base de toda industria fabril y mercantil agoniza, por cuya razón, el comercio carece de transaciones; muchas fabricas que antes no podian satisfacer los numerosos pedidos que de sus 
productos tenian, se encuentran ahora cerradas, y otras sin funcionar la mayor parte del año; centenares de miles de fincas están abandonadas por sus dueños, yermos por haberles invadido la filosera, la langosta ó un aluvión, muchas viñas sin cultivar y las bodegas atestadas de vino por no haber quien lo compre á ningún precio, todas estas y otras circunstancias análogas motivan los sinsabores y amarguras que sufre el resignado agricultor y por las que se halla imposibilitado materialmente de satisfacer las crecidas cuotas que se le exijen; y todavía la Hacienda apremia sin consideración á los contribuyentes y emplea la fuerza pública para cobrar los tributos. Aún así los abatidos agricultores tienen ocupados à muchos obreros en el cultivo de la tierra, facilitándoles al propio tiempo el sustento diario para si y sus respectivas familias: pero ¿qué sucederá el día en que aquéllos no puedan dar jornal?

El Estado, pues, debe preocuparse sériamente de la situación tan grave y excepcional de los productores, atender al desarrollo y fomento de la agricultura como á la primera necesidad de la nación, y proteger por igual todas las manifestaciones de riqueza, á la vez que los intereses y derechos de todos sus administrados; en particular los que se 
encuentren más desatendidos y necesitados de remedios como los intereses agrarios gríndemente comprometidos que necesitan la protección decidida de los poderes públi. cos, como un enfermo ánémico necesita de reconstituyentes enérgicos.

Es en extremo sensible que España, que cuenta con envidiables veneros de riqueza la feracidad de su suelo, y los importantes medios y recursos de que puede disponer, no se preste mayor atención a las cuestiones agrícolas, y de continuar relegando al olvido lo que tanto y tan directamente afecta á la producción nacional, llegará dia en que los industriales tengan que cerrar por completo sus fábricas, los comerciantes sus tiendas ó comercios, los propietarios y labradores se conviertan en braceros, y á éstos se les obligue á emigrar á paises extraños, renunciando á la familia, amigos, y al suelo en que nacieron, ó tengan que afiliarse á las decantadas ideas utópicas modernas, á las que los obreros del campo fueron siempre refractarios.

Los agricultores tienen su pan é intereses en manos de sus gobernantes, y la poca protección que se dispensa á los que se dedican al cultivo de los campos, y riegan la tierra con el sudor de su rostro, es la causa á que 
principalmente obedece el malestar profundo de la numerosa clase agricola, la cual yace hoy sumida en la mayor postración y abatimiento. Sus constantes reclamaciones por nadie han sido atendidas y sus lamentos se han perdido en el desierto de la más glacial indiferencia, sin que encuentre alivio á los muchos males que la aquejan.

Por otra parte, las numerosas plagas de insectos y las diversas enfermedades criptogámicas asolan los campos y destruyen los plantios, sembrados y viñedos, y hasta los elementos atmosféricos contribuyen también en ocasiones á acibarar más la situación del pobre agricultor; pues no ya un vendabal furioso, ó un ciclón con su tromba del agua y granizo que en su impetuosa corriente arrastrar lo mismo las mieses y las plantas que los hombres y ganados, y todo cuanto encuentra al paso, sinó un fuerte aguacero, una prolongada sequia, una escarcha matinal, un cambio brusco de temperatura, todo parece que algunas veces se conjura y todo en breves momentos puede destruir las esperanzas, los afanes, desvelos y trabajos del pacifico é infortunado labrador.

El mar, según ha dicho Michelet encariña de tal manera á los hombres, que por largo tiempo se confian á sus peligros que no 
les es dado abandonarlo jamás. Pues lo propio puede decirse de los hombres que se dedican al cultivo de la tierra, los cuales, á pesar de tantos infortunios, de tanto sufrimientos y de tantos desengaños, sintetizan su resignación en aquel adagio: viva la gallinila, $y$ viva con su pepila.

Hora es ya, de que los Gobiernos se ocupen más del bien del pais que la política de partido, por ser el mejor medio de que la producción nacional alcance su verdadero y sólido desarrollo, y de que obtenga algún alivio la numerosa clase agrícola, hoy tan afligida y castigada, no obstante ser la que a costa de muchas privaciones y trabajos, arrancá à la tierra los productos indispensables para sostener à la humanidad.

La crísis agraria, requiere urgentes y eficaces remedios.

La crisis agricola y pecuaria es en verdad en nuestra nación latente y profunda; todos la vemos, en todo repercute, y en toda ocasión y momento la tocamos y palpamos. Por tanto, seria una puerilidad imperdonable detenernos á demostrar su existencia, lo cual no conceptuamos necesario, como tampoco lo es demostrar que es de dia en la parte de 
nuestro planeta, en que el sol derrama su luz radiante y vivificadora, y para precisar con exactitutud las diferentes causas à que aquella obedece, como son tan patentes, claras y manifiestas, no se necesitan grandes esfuerzos; pues el enfermo que aqueja fuertes dolores señala con puntualidad la parte afecta ó dolorida; y cuando un edificio, tanto en su parte interior como exterior tiene anchas grietas, no es difícil apreciarlas al mas ligero reconocimiento.

Asi, pues, á poco que nos detengamosá observar las diferentes causas de la honda crisis agricola, y por consiguiente del empobrecimiento y malestar del pais, veremos, entre otras, comolas masprincipales, la muy escasa atención é importancia que nuestros gobernantes y la mayoria de los hombres políticos conceden á las cuestiones agrícolas; la complicada legislación administrativa que entorpece toda iniciativa provechosa, y los muchos obstáculos que seoponen al desarrollo de cualquier industria y al de todo proyecto beneficioso para la producción nacional; la poca moralidad administrativa; la falta de buenos tratados de comercio; de mercados para nuestros vinos; de instrucción agricola; de capitales; de seguridad en los campos; de población rural; de espíritu de asociación 
entre las clases productoras; de una estadistica oficial exacta; la escasez de aguas: pastos y abonos naturales; los crecidos tributos que graran la riqueza rústica $\mathrm{y}$ pecuaria; la mucha indiferencia hacia la agricultura; la pérdida del todoó parte de las cosechas: hallarse muy subdividida la propiedad, la baratura de los productos; las pocas facilidades y el excesiro coste para el transporte de los mismos á las fronteras y puertos del litoral, 5 la aglomeración en éstos de otros productos analogos procedentes del extranjero; y otrás di. rersas circuastancias ya secundarias, ya erentuales ó nacidas del ricioso sistema económico-administratiro.

En tal concepto, enumeradas sucintamente las causas originarias del hondo malestar que sufren los agricultores, el objeto principal de ouestro trabajo, es el de proponer los medios que conceptuamos más practicos y de nerdadera eficacia para remediar óaliviar el malen sus peraiciosos efectos; lo cual es dificil, pues aunque el médico diagnostique con acierto una enfermedad. no siempre tiene à su disposición los remedios terapéuticos indicados para combatirla, y menos cuando aquélla esincurable ó ya muy crónica y grare, $\mathrm{y}$ durante el tratamiento curatiro, se presentan multitud de complicaciones que 
otras agravan unas veces el estado del enfermo, y dificultan la completa curación de la dolencia que padece.

Afortunadamente, los males que el agricultor lamenta, aunque crónicos y graves, no son incurables, ni de muy difícil aplicación los remedios, sino para curar radicalmente el mal, por lo menos para aliviarle y contenerle en los estragos que produce, siem pre que haya buena, buena fé en todos los hombres entusiastas del bien público y de la prosperidad nacional; pero como la gravedad de la dolencia, no admite espera, la aplicación de los remedios habrá de hacerse con la mayor premura, sin la menor dilación, porque si se camina con lentitud, entónces tendrá plena confirmación el consabido refrán: mientras la yerba crece, el buey perece.

Deberes que la pátria impone á todos sus hijos.

Remediar los males presentes, y evitar en lo posible los futuros, es en verdad altamente plausible y provechoso, á cuyo fin deben encaminar sus propósitos con paso firme $y$ persererante todos los buenos 
Gobiernos; y el coadyuvar á la consecución ue una obra tan eminentemente regeneradora, es un deber apremiante y sagrado que impone la pátria á todos sus hijos, para que cada cual le ejercite en la medida de sus. fuerzas y facultades.

Tal es el objeto exclusivo de nuestro modesto trabajo al decidirnos á prestar nuestra insignificantecooperación sin pretensiones várias que serían ridiculas porinmodestas, y sólo. por considerar un deber de patriotismo, no permanecer en la más estóica indiferencia ante un problema que á todos interesa de una manera tan directa, y que por lo mismo, también todos, altos y bajos, grandes y chicos, doctos é indoctos, estamos obligados á elaborar en él y á aportar cada cual su grano de arena para reconstruir y sostener el edificio que salve á la producción nacional de la inminente y espantosa ruina que amenaza, y que de consumarse, sepultará entre sus escombros el más importante ramo de nuestra riqueza pública, y la miseria y el hambre sobrevendrán necesariamente con sus terribles consecuencias.

La magnitud de la empresa será seguramente superior á nuestras fuerzas; pero si no llenamos cumplidamente nuestro propósito, no obedecerá á falta de buena voluntad 
para contrarrestar ó mitigar siquiera los muchos males que el pais lamenta; y ya que no sea posible la felicidad humana sobre la tierra, debemos aspirar à su constante, aunque lento perfeccionamiento, pues con lentitud, es como mejor se modifican las ideas y costumbres de los pueblos; caminando despacio por el proceloso mar de la Administración del pais para evitar más fácilmente toda clase de escollos, arrecifes y el impetu de embravecido oleaje, y poder arribar sin riesgo ni sobresaltos á la hermosa y florida playa en que se desarrollen y fructifiquen la instrucción, el progreso, la moralidad, el órden, la producción y el trabajo.

Las obras de los hombres no pueden ser perfectas, porque la perfección suma solo en Dios existe, y por consiguiente, menos ha de serlo la nuestra, aunque confeccionada con la mayor sencillez, concisión y claridad que nos ha sido posible, animados de la mejor voluntad ante la idea generosa del bien púplico; huyendo de abstracciones metafísicas, de utopias irrealizables, y de todo cuanto hemos conceptuado perjudicial y quimérico; como también del vulgar y halagador sistema de pedir rebajas en toda clase de tributos, las que si se realizasen, además de mermar ostensiblemente los recursos del Tesoro 
no se obtendrian beneticios positivos (1); pues si bien reconocemos la inconveniencia y aún la imposibilidad del aumento de gravámenes, porque apenas se puede ya con los actuales, también es evidente que un agricultor con la rebaja de 25 ó 30 pesetas en su tributación anual, poco ó nada ganaria, si las cosechas son deficientes y sus productos no tienen salida, ó si los precios no son remuneradores; como el obrero que consiga la rebaja diaria de quince j veinte céntimos de peseta en el precio de los articulos indispensables para su consumo y el de su familia, si debido á este pequeño beneticio nadie le puede facilitar después colocación ó trabajo; y de la propia manera que el labrador que por evitar gastos escasea los abonos, aperos y labores de cultivo y la adquisición de obras ó revistas útiles, si después por tal circunstancia obtiene cosechas muy reducidas, cuyas pérdidas

(1) Si bien es cierto que el pais anhela economias, tambièn lo es que éstas requieren tino y equidad para efectuarlas; pues una economia mal entendida, como la de suprimir un organismo necesario, equivale á un despilfarro; y no debe olvidarse el malestar general y las grandes molestias que multitud de pueblos sufren por la supresión de sus respectivos Juzgados, carterias y peatones. 
superan con mucho à las economias con tan grave y manifiesto error realizadas.

Aunque cerciorados de que es más cómodo y sencilio proponer que realizar, y más fácil soslayar que tratar á fondo los problemas, proponemos, si, ciertas reformas y la supresión ó modificación de los impuestos más gravosos y perjudiciales á la producción nacional; pero á cambio de que sean sustituidos por otros nuevos; así como también mencionamos algunos que, aun cuando tienen más bien el carácter de voluntarios por la indole especial de los mismos, podian obtenerse de su realización considerables rendimientos. Además indicamos diferentes reglas y disposiciones, cuya iniciativa y desarrollo corresponde exclusivamente al Estado, y las que por obedecer á factores ajenos á su poder y jurisdicción es la incumbencia de las Diputaciones provinciales, Ayuntamientos y particulares, precisándolas con la minuciosidad que nos permite la naturaleza de esta obra y detallando los medios que conceptuamos más conducentes, prácticos y viables para cada caso (I),

(i) En alguno quizá con demasiada dureza, 6 con la aridez propia de la verdad escueta; pues siendo enemigos por temperamento á la adulación y lisonja, entendemos que es preferible decir la verdad que 
encaminados al importante fin del gran programa en que va envuelto el supremo interés del pais, como los más adoptables al mismo; pues para obtener el mejor resultado posible en toda clase de reformas, debe atenderse al estado peculiar de cada nación, su historia, carácter, costumbres, religión, riqueza pública y privada, grado de cultura, época, tendencia, manifestaciones, movientos bibliográficos, etc., porque no en todas pueden informarse, ni tener igual aplicación unas mismas

a marga á la adulación que ofusca (por lo de «el amigo y el espejo-tienen entrambos á dos-un mismo oficio y así-el más claro es el mejor), pero sin que sea nuestro ánimo molestar en lo más mínimo á clase alguna, ni persona determinada, todas dignas de protección y respeto; y por lo mismo si en nuestro trabajo hubiere alguna palabra ó idea algo dura, nadie se considere ofendido, pues nuestro deseo solo tiende á reflejar la situación del país, que quisiéramos poderlo verificar con la misma fidelidad y exactitud con que un espejo refleja la fisonomia que ante él se presenta; y poner al descubierto la llaga para conprender mejor su extensión, á fin de que hábiles operadores puedan llevar hasta el fondo de la herida el saludable cauterio que sane la llaga que tanto hace sufrir al paciente; procurando en todo caso harmonizar intereses generales, y mantener harmónicamente la relación del derecho con el deber, por conceptuar que asi llenamos mejor nuestro propósito, y ya que, según Montaigne, cuando no hacemos el deber, debemos al menos desearle y reconocerle. 
leyes, doctrinas y procedimientos; como tampoco es conveniente adoptar el mismo tratamiento curativo en toda clase de personas, aun cuando la enfermedad sea la misma, sinó que, además de otras diversas circunstancias. es necesario tener en cuenta el sexo, edad, constitución, temperamento, hábito ó costumbre, posición social del individuo enfermo, y hasta su idiosincrasia; porque también está demostrado que lo que es beneficio. so para un enfermo, aplicado á otro individuo con la propia dolencia, el resultado es perju dicial y contraproducente; y de la propia manera que no da resultados el uso ó empleo de una misma semilla en toda clase de terrenos, sinó que es preciso tener presente el clima, calidad del terreno, estación, labores realiza das, razón, costo y otras condiciones no menos esenciales.

La crisis porque atraviesa el pais, es en verdad triste y angustiosa; los temores aumentan; el malestar crece; las protestas nacen por doquier; el horizonte se va cubriendo cada vez más de siniestras nubes, y una acer . tada solución al vitalísimo problema agricola es sin duda alguna la única esperanza redentora, el blanco lirio de la paz, el verde ramo de oliva, la hermosa flor de la acacia, que pueden desvanecer la tormenta; y con ella los 
peligros y trastornos que todos los hombres. de buena voluntad debemos procurar evitar, aunque para ello sean indispensables prodigiosos y titánicos esfuerzos.

Lenta y laboriosa ha de ser tan azarosa y patriótica tarea; pero entendemos que no tan árdua como la de resolver la cuadratura del círculo, el movimiento contiene, la piedra filosofal y la dirección de los globos; y porque si querer es poder, entendemos por lo primero, los buenos propósitos y deseos que seguramente no habrán de faltar á la inmensa mayoría de los españoles entusiastas de la prosperidad nacional, persuadidos de que el progreso y desarrollo de la agricultura conducen por camino directo y seguro al bienestar de naciones; y que si se ha de conseguir que España vuelva á ser digna de mejores destinos, ha de ser empezando por fomentar con verdadera decisión y entusiasmo la riqueza agraria, hoy la más abatida y necesitada de remedios.

Aun es tiempo de abrir el corazón á la esperanza; celajes de un rosado porvenir se dislumbran en el horizonte; y ya la aguja indic adora presiente en vez de las crudas y violentas boreas, plácidos y suaves favonios. No es que nos dejemos llevar por optimismos exagerados, ni que sea pueril ilusión de nuestro 
deseo, porque el buen sentido nacional se impone ante la necesidad tan apremiante de remediar los muchos males que pesan sobre nuestra nación, siendo indudable que para empresa tan levantada, no habrá de faltar el más decidido y sincero apoyo de todas las clases sociales amantes del bien público, á fin de que al perderse en su ocaso el siglo de mayor progreso que ha tenido la especie humana, brille en toda su plenitud la aurora de un porvenir en relación con nuestro pasado, inaugurando de tal modo una era de prosperidad para la pátria.

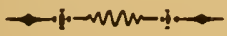





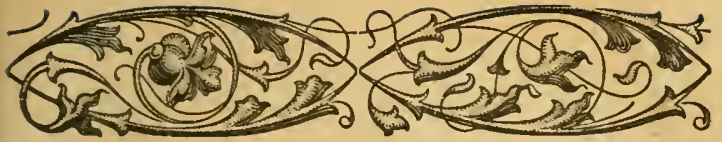

\section{PARTE PRIMERA}

MEDIOS GENEFAIES

\section{CAPITLO PRIMERO}

Importancia capilal del problena agricola.

1. Las naciones más florecientes son las que más protección dispensan á la agricultura.

2. En España se ha llegado al "sumun" de los derechos politicos.-Los problemas agrícolas son los que requieren mayor interés y el concurso de todos los buenos españoles.

Los problemas relacionados con la Agricultura, la más importante sin duda alguna de todas las riquezas conocidas que en el mundo 
existen, son de tal naturaleza y revisten caracteres de tan excepcional importancia, que no es posible estudiarlos y menos resolverlos en la propia forma que las cuestiones politicas, administrativas, financieras y comerciales, y que cualquier otra que en la vida social pueda presentarse bajo sus diferentes aspectos y manifestaciones.

Al consultar la historia de todos los pueblos y naciones para conocer su estado de prosperidad ó decadencia; al hacer un exámen analítico y profundo para poder apreciar las grandezas y vicisitudes porque ha atravesado la humanidad desde los tiempos más remotos hasta nuestros dias, notaremos desde luego que todo aquel engrandecimiento que admiraron lo mismo en los pueblos antiguos que modernos; que todas las épocas que más se han distinguido por su esplendor en los fastos de las naciones con indelebles é imperecederos recuerdos; y que todos los momentos de mayor entusiasmo y verdadera felicidad conquistados con glorioso afán por el linaje humano, fueron debidos á los inmensos beneficios que moral y materialmente reporta á la humanidad entera la muy noble, elevada é importante misión de cultivar los campos, y al decidido apoyo prestado á la agricultura; fuente peremne de riqueza, cimiento firme de la humanidad, base de toda industria, sostén del comercio, de la que 
proviene la paz, el orden y el poderio de las naciones y el bienestar de todas las clases sociales.

Los egipcios, en su espiritu emprendedor de laboriosidad y amor al trabajo, se dedicaron con afán y provecho al cultivo de los campos desde la más remota artigüedad, y consiguieron ver á su país en el estado mis próspero y floreciente. El trigo ya se cultivaba en Egipto 4.000 años antes de la era cristiana. Según el Génesis, debido á los cuidados de José $y$ á la protección de los Faraones, las zonas bañadas por el Nilo suministraron trigo á todos los países en que el hambre por la escasez de cosechas ocasionaba sus naturales estragos. Por consecuencia del desarrollo tan admirable de su agricultura llegaron además los egipcios á un grado de progreso y cultura de que sus famosas piramides, una de las maravillas del mundo antiguo, son mudos y elocuentes testigos. La población egipcia creció rápidamente y se hizo colonizadora, llevando su laboriosidad y sus buenas prácticas agrícolas á casi todas las regiones del globo.

Los hebreos, fenicios y caldeos, y más aun los árabes cansados de la vida nómada y aventurera, llegaron á persuadirse de la conveniencia de cultivar las tierras, y del trabajo agrícola abtenían abundantes productos; siendo de admirar la aptitud y constancia de 
los últimos, y el estado de prosperidad a que llevaron algunas comarcas de nuestra peninsula, y las portentosas obras que todavia se conservan como vestigios de su laboriosidad y civilización.

La populosa China, la India, Persia y el Japón han disfrutado largos siglos de los inapreciables beneficios de paz y prosperidad, y llegado á constituir un poderoso elemento para la cibilización, por naberse dedicado con la mayor asiduidad al cultivo de la tierra, cuyas producciones alcanzaron desde los tiempos primitivos un desarrollo extraordinario.

La riqueza, poderío y el bienestar que disfrutaba la peninsula italiana antes de la fundación de Roma, fué por el trabajo inteligente y perseverante en el cultivo de los campos. Al principio de la dominación romana manejaban el arado y demás instrumentos de labranza los más ilustres heróicos y entendidos generales, persuadidos de que las labores de la tierra eran más útiles y provechosas que las conquistas de la guerra. El abandono de tan beneficiosas prácticas agricolas originó posteriormente el descenso de la producción, la pobreza, el malestar general, y la decadencia y ruina del imperio. 


\section{Las naciones más florecientes}

son las que más protección dispensan á la agricultura.

Hoy dia vemos también que las naciones que más protección dispensan á la agricultura son las más ricas y florecientes.

Alemania, imperio poderoso, con cuatro Institutos Agronómicos, Escuela agronómica superior. Academia real económica, Academias reales forestales, Escualas de veterinaria; dieciseis escuelas agronómicas secundarias; treinta y tres granjas-escuelas; las escuelas agronómicas de invierno; Escuela real de pomologia y viticultura; Escuela superior de jardineria, y otra multitud de centros de enseñanza agrícola, con laboratorios de análisis de tierras, abonos y semillas; más, pero mucho más que la organización militar ha contribuido á su engrandecimiento el apoyo entusiasta por parte del Estado en favor de la agricultura, y el fruto obtenido con tanto aprovechamiento de la enseñanza agrícola. Es tambien lo que tiene por base y á que principalmente obedece la lisonjera situación de la riqueza pública y privada del Imperio, que le ha convertido en casi árbitro y dueños de los destinos europeos.

Francia que sigue las huellas de todos los adelantos científicos, y en cuanto á la enseñanza agrícola progresa rápidamente, con 
interesantes revistas agrícolas y pecuarias; Escuelas de riegos, de pastores, horticultura, politécnica de agricultura, de veterinaria, especial de viticultura, de sementales, agricultura práctica, Institutos agronómicos, etc., etc. y más de 50 colonias agricolas destinadas á recibir los niños pobres ó huérfanos para educarlos y enseñarles las praticas agricolas: todo lo cual contribuye de una manera prodigiosa á propagar los nuevos adelantos científicos en el cultivo de los campos, que unido á la decisión que demuestran los Poderes públicos por favorecer los intereses agricolas, hace que esta nación sea una de las más ricas, civilizadas y poderosas.

Austria-Hungria, Bélgica, Inglaterra, Rusia, Suecia, los Estados Unidos, el Brasil, Chile, la Colombia y el Perú en cuyos paises la agricultura hace rápidos progresos, por el impulso inteligente y constante en el cultivo de lus campos, y a que principalmente se debe la preponderancia, riqueza y poderio que disfrutan sus respectivos Estados.

La Italia moderna, cuya situación económica no es en la actualidad nada envidiable por los cuantiosos sacrificios que la ocasionan la paz armada y las consideraciones de nación de primer órden, sin la decidida protección que se concede á la agricultura, lo mucho que se estimula su progreso y desarrrollo, y las importantes mejoras realizadas 
en las prácticas agrícolas, la existencia del Estado se haria punto menos que imposible.

Y España, nuestra pátria, antiguo granero de Roma, pais esencialmente agricola más que ninguna otra nacción, cuyas nueve décimas partes, ó sea la casi totalidad de sus 18 millones de habitantes se dedican al cultivo de los campos y viven de la agricultura; sin que á esta pueda compararse con ninguna otra riqueza, ni industria alguna conocida por la indole especial que le es peculiar y distingue de las demás, su angustiosa situación exige imperiosamente un estudio constante, una voluntad firme y el apoyodecidido y sincero de todos los buenos patriotas, á fin de llevar á la práctica remedios variables y eficaces.

La lucha incesante de los partidos; el fragor de los que se disputan á porfía un principio más conservador, liberal ó democrático que informe las leyes constitutivas del régimen de los Estados; las discusiones ardorosas entabladas y sostenidas en el Parlamento, en la prensa, y hasta en las conversaciones por la consecución de lo que suponen un derecho y que á veces resulta un inconveniente, ó un arma colocada en mano inexperta, ningún bien positivo reportan ni nada significan al bienestar y engrandecimiento de las naciones, antes bien debilitan los vinculos de respeto, cariño, confianza y

Crisis agrígola. 
protección mútua que deben existir entre gobernantes y gobernados para consolidar la paz, desenvolver armónicamente todas las fuerzas del capital y del trabajo, y salvar á la producción nacional de la postración en que se encuentra.

En nuestra nación no hay problema politico que resolver, porque tenemos verdadera plétora de derechos políticos, y nos hallamos en el summum que nos es dado obtcner. El pais está ya cansado de discusiones políticas, frivolidades pasajeras y estériles lirismos, y sólo ansía las discusiones pacíficas encaminadas á fomentar la producción nacional, porque sabe que ningún bien entraña, ni nada valen las cuestiones politicas al lado de las económicas. El sufragio universal, por ejemplo, (aparte del derecho que representa, por todos reconocidol una de las denominadas - conquistas modernas», nada resuelve, ni contribuye en nuestra nación, como todos sabemos, á ningún fin práctico y positivo.

Los problemas agrícolas, por el contrario, merecen la atención asidua y preferente de todos los partidos políticos, sin distinción alguna, porque las cuestiones de partido deben subordinarse á las de interés común, posponiendo el logro de aspiraciones personales al bien del pais, pues antes que el egoismo de partido está el verdadero concepto de la pátria, los prestigios é intereses de la 
misma y de sus instituciones; y por lo mismo que aquellos son tan àrduos de estudiar como difíciles de resolver, requieren un esfuerzo supremo y la unión de todos para contener los efectos de la crisis pavorosa que atraviesan las clases productoras.

El pan de cada día es una potencia de mucha fuerza en nuestra dinámica nacional, asi es que el pueblo que tiene hambre, pedirá pan, y no derechos políticos, puesto que con ellos no habrá de saciar la necesidad de alimentarse; de aquí también que concedamos una importancia culminante y vital al problema de que nos ocupamos, y cuyo favorable éxito podria influir de una manera eficaz para la acertada solución de todos los demás. En él va envuelta la vida ó la muerte de la agricultura española, y de cuya solución depende la suerte próspera ó adversa tanto del propietario como del industrial, comerciante, letrado, artesano, y muy directamente la del bracero.

«No cabe hoy, por lo tanto, para nosotros cuestión más grave que esta; en la solución de este problema va envuelto un dilema, cuyas aterradoras alternativas encierran decretos de vida ó muerte para nuestra nación (I)».

(1) Sánchez de Toca, en su obra La Crisis agraric Europea y sus remedios en España. 
"Generalmente han alcanzado larga vida y han dejado huella en la historia y en la civilización aquellos Estados en que los agricultores han gozado la consideración que les. es debida, mientras que los pueblos nómadas ó exclusivamente guerreros ó han permanecido en la abyección de la barbarie, ó han pasado por la tierra cual tempestades que deshace el viento, y que sólo siembran terrores y desdichas convirtiendo en asoladora la benéfica lluvia (1)».

Todo, según Sully, prospera en los Estados donde fforece la agricultura. Así también lo reconoció el monarca francés Luis XV persuadido de las inmensas ventajas del cultivo de la tierra, cuando exclamó: Pobres. campesinos, pobre reino.

¿Qué verdad tan luminosa! ¡Qué sentencia tan sabia! ¡Qué axioma tan provechoso! Y no hay que dudarlo; si próspera es la vida de la agricultura, próspera y lozana será la vida nacional; y si pobre y extenuada, pobre $y$ raquitica arrastrará el pais su existencia, porque la base de la vida de los pueblos, su riqueza y bienestar, están en lo que produce su suelo, siempre que sus pruductos sean siquiera módicamente remunerados.

(1) B. Aragó. (Diccionario enciclopédico de agricultura y gariadería é industria rural, bajo la dirección de los Sres. López Martínez Hidalgo, Tablada y Prieto y Prieto, Tom. 1). 
"Sin agricultura no puede haber industria ni comercio, porque la industria se alimenta de la agricultura tomando de esta las primeras materias, y el comercio crece y se desarrolla con el cambio de los productos de ambas, llevando à la industria los productos de la agricultura y devolviéndoles á esta y al consumo elaborados (I)".

$\mathrm{El}$ interés que en todos los pueblos inspiran las cuestiones agricolas es cada dia más evidente. La agricultura es ademas la madre de todas las industrias, la principal de nuestra pátria, y la que más beneficios reporta á la humanidad; y hoy que vemos que las naciones que más protección dispensan á la agricultura son las más ricas y florecientes y las que mayor bienestar disfrutan, estamos seguros de que en esta patria gloriosa, en esta nación queridisima no habra de faltar el talisman que fortalece los ánimos para afrontar las más heróicas empresas, y que consiste en el más puro y acendrado patriotismo.

La flor de la historia de España siempre fué el patriotismo, el cual jamás escatimará el pueblo español que sabe ser pródigo en abnegación y sacrificios en aras del bienestar de la pátria, y de todo cuanto conduzca á su regeneración y engrandecimiento.

(1) A. Cañas, en su obra Presente y porvenir de la agricultura española. 



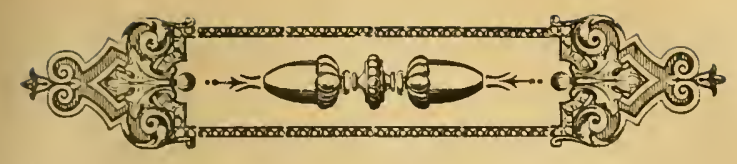

\section{CAPÍTULO II.}

La buena Administración priblica.

1. En qué consiste.

2. Ha de ser extensiva á la Provincia y Municipio. - Recompensa que merece.

Antigua y elástica por demás es la palabra Administración, porque cada uno suele darle un valor distinto y una acepción tan diversa como lo sea el objeto á que sela aplique y las propiedades que cada cual le atribuye; pero sintetizando las definiciones de eruditísimos y competentes autores como Abella, Alcubilla, Cantalapiedra, Freisa, Hurtado, Ahrens, Bechard, Guizot, Holtzendorff, Laferrier, Macarel, Mesedaglia, Rousseau, Savigni y otros diremos, aunque sin pretender en este punto aproximarnos a lo exacto y menos á lo perfecto, que puede considerarse aquella la institución encargada de regir los destinos públicos con atemperancia á las leyes, ó de otro modo y para expresarnos con mayor claridad, los Ministros de la Corona (que son los Jefes de 
la Administración) Gobernadores, Diputacio: nes y Ayuntamientos y demás entidades, personas encargadas de promover los intereses públicos, evitar el mal y realizar el bien; cuya definición nos parece quees la que más se aproxima á la de Bechard que dice ser aquella ala dirección y manejo de los negocios locales y nacionales por la organización y funcionamiento del municipio, de la provincia y de la nación» y según Macarel wel brazo del cuerpo político cuya cabeza se halla en el Gobierno».

Muchos opinan porque se separe la Politica de la Administración y que ésta obre con entera independencia de aquella; lo cual no conceptuamos por ahora muy factible, teniendo en cuenta que nuestra organización politica y administrativa es moderna, yá que en la actualidad la Politica (1) no es otra cosa que el medio para llegar á la Administración.

La Política y la Administración deben pues marchar unidas en su desenvolvimiento y prestarse mútuo y reciproco apoyo, ya que no puede prosperar, ni desenvolverse la una

(1) Por tal entendemos no la serie de ardides de todo linaje que los partidos $\mathbf{y}$ adeptos de las diversas escuelas suelen utilizar en su favor, sinó la ciencia del gobierno de las naciones, cuyo ramo más importante es el referente al modo de constituir los Poderes públicos. 
sin el concurso de la otra, pues conforme con el Sr. Nocedal, no hay manera de tratar las cuestiones económicas sin tratar al mismo tiempo las cuestiones políticas, porque dependen unas de otras como el efecto de la causa; y según el Sr. Posada Herrera, no puede haber buena Administración donde la Politica no ha creado instituciones libres y bastante robustas para garantir el orden y asegurar la acción eficaz del Estado en la esfera administrativa.

Definida con la posible brevedad la palabra Administracion y expuesta de una manera muy sucinta la conveniencia de que marche unida á la Politica prestándose mútuo auxilio para los importantes fines que mencionaremos después, creemos no estará de más consignar que aún cuando parezca una pequeña digresión entendemos que no lo es, porque en nuestro concepto la primera circunstancia, la más esencial, de mayor eficacia, de más provechosos resultados, la que ha de contribuir de un modo más directo é inmediato para la mas acertada solución del pavoroso problema agrícola y pecuario, y de la que sin duda alguna se derivan todas las demás, es la que nos sirve de epigrafe á este artículo. Y si hemos de lograr para nuestra nación algún alivio á los muchos males que le aquejan; si hemos de conseguir mayor desarrollo en todas las fuentes de riqueza, y 
evitar el hondo malestar que el pais con so: brada razón lamenta, ha de ser empezando por una buena Administración pública.

En qué consiste.

Y qué es, cómo ha de ser, y en qué consiste una buena Administración.

Como tal consideramos al Gobierno que logre para nuestra querida España moralidad, justicia y hon radez administrativa.

Que atienda al desarrollo y fomento de la riqueza agricola y pecuaria, asi como también al de las ciencias, las artes, la industria y el comercio, pues aun cuando no tanto como los agricolas y pecuarios son asimismo elementos contributivos y ramos valiosos de nuestra riqueza pública.

Consolide la paz y el orden, base del bienestar de las naciones.

Fomente la instrucciún moral y cientifica, primera necesidad de un pueblo que tanto civiliza y engrandece, y en la que se halla comprendido la enseñanza agricola; debiendo favorecer la costumbre donde ya la hay, y establecerla en las muchas poblaciones que no. existe de reunirse los labradores para leer y discutir las instrucciones y enseñanzas contenidas en las cartillas y revistas de propa-ganda agrícola, estimulando por medio de recompensas á los que de aquellas obtengan mayores frutos y adelantos. 
Sostenga la moral en las costumbres públicas.

Atienda con predilección à la beneficencia pública, patrimonio sagrado de los pobres.

Organice el Ejército, salvaguardia de la paz y del orden, y de la integridad de la pátria, verdadera garantia y sostén de la dignidad nacional; facilitándole todos los medios necesarios á fin de que pueda atender á.las eventualidades del porvenir.

Dote á la marina de los elementos precisos para la defensa de nuestros derechos en el mundo.

Conserve las relaciones más cordiales con los demás Estados, y sea neutral en las luchas que entablen entre los mismos; sin perjuicio de sostener debidamente los derechos de la pátria, á la vez que sus cristianas y tradicionales virtudes.

Garantice la seguridad personal, y las haciendas é intereses de los ciudadanos.

Afirme el crédito público tanto en el interior como en el exterior.

Combata el fraude en todas sus manifestaciones.

Concierte buenos tratados de comercio al importantísimo objeto de abrir mercados para la producción nacional, y con ellos anchos y despejados horizontes para la agricultura y ganaderia. 
Que se dedique con asiduidad al estudio de las cuestiones económicas para distribuir las cargas contributivascon la mayor equidad, según los productos de la riqueza respectiva y harmonizar los derechos de la Hacienda con los de los contribuyentes de buena fe.

Huya de empréstitos ruinosos considerados por la ciencia como anti-económicos.

Procure la nivelación verdad de los presupuestos, y posteriormente el logro de sobrantes en los mismos que permitan ir amortizando las crecidas obligaciones que pesan sobre el Tesoro, rebajar equitativa $y$ gradualmente los tributos, y atender á la construcción de obras de utilidad pública.

Lleve al propio tiempo economias á todos los servicios que las consientan; averiguando antes si aquellas son legitimas, ó si por el contrario constituyen un despropósito que necesariamente habrán de dejar abandonados importantes servicios públicos.

Simplifique la legislación civil juridica y administrativa, para que los procedimientos sean mas breves, y á la vez menos complicados y costosos que lo son en la actualidad.

Cumpla, y haga que por todos se cumplan las leyes.

Castigue la inmoralidad y la neglicencia, y recompense el verdadero mérito.

- Provea por oposición verdad y rigorosa todos los destinos públicos que su indole lo 
permitan, para lo cual se atenderá únicamente al mérito y no al favor de los aspirantes; debiendo considerar inamovibles á los que en tal concepto resulten nombrados, cuya separación ó cesantía solo podrá tener lugar por faltas cometidas en el ejercicio de su respectivo cargo, base de la responsabilidad, de todos y cada uno de sus actos.

Evite, en cuanto esté de su parte, la emigración á paises extraños, pues en algunas localidades (si bien poias por fortuna) solo quedan los ancianos, las mujeres y los niños.

Prohiba los juegos ilícitos, las repugnantes, pornografias, y las execrables blasfemias.

Estudie con el detenimiento debido todo lo concerniente á una acertada solución que permita reglamentar el capital y el trabajo para evitar en lo posible divergencias y reclamaciones entre propietarios y obreros.

Constituya sociedades colonizadoras para fomentar la riqueza y derechos de nuestras posesiones ultramarinas.

Solvente el completo pago de los créditos tan sagrados y legitimos que se adeudan á los licenciados y herederos de los fallecidos en los lejanos y ardorosos climas de allende los mares, y que han derramado su sangre por la int egridad de la pátria.

Proceda con discrección, tino y prudencia, debiendo huir de intemperancias y precipitaciones que suelen ser compañeras 
inseparables de errores y desaciertos; pero sin desdeñar la oportunidad ó la fortuna cuando se presenten.

Un Gobierno, como decía el esclarecido Balmes, que ni desprecie lo pasado, ni desatienda lo presente, ni pierda de vista lo porvenir.

Que la templanza, la mesura y la corrección sean la norma de sus actos, debiendo aspirar más que á ser temido, á ser querido, evitando imponer por la fuerza y el castigo lo que pueda conseguir por la razón y el convencimiento; pero si no le fuere posible lograrlo no obstante los medios adoptados á tal objeto, proceda en tan sensible caso con mano fuerte, y si ser puede antes que el mal se consume, puesto que vale más precaver que corregir, y su misión es prever siempre los acontecimientos.

Y todo cuanto además conduzca á que la moralidad más pulcra impere en todos sus actos; base principal como ya hemos afirmado, para el fomento de los intereses agrícolas y pecuarios hoy muy desatendidos y necesitados de remedios.

Ha de ser extensiva á la Provincia y Municipio.

Mas para que la Administración sea fecunda y provechosa ha de ser secundada de 
una manera eficaz por las Provincias y Municipios.

Nadie duda ya, por ser un hecho inconcuso y evidente que la buena Administración pública debe ser extensiva á las Diputaciones provinciales y Ayuntamientos, formando con la del Estado un engranaje y verdadero complemento, para el mayor impulso, enlace y buena marcha de la complicada máquina administrativa.

A los Ministros como Jefes de la Administración, corresponde la ejecución de todas las leyes de interés general, y como consecuencia la expedición de los decretos, reglamentos é instrucciones conducentes al objeto; y á las Diputaciones provinciales y Ayuntamientos el más puntual y exacto cumplimiento de las mismas disposiciones emanadas del Poder central.

En la Constitución vigente al definir las instituciones administrativas con la misma exactitud que las políticas y después de establecer lo concerniente à los derechos y deberes de los ciudadanos, hállanse consagradas las prerrogativas del Monarca en quien reside la plenitud del Poder ejecutivo, la manera de ejercerlo por medio de sus Ministros responsables, y la existencia de Diputaciones y de Ayuntamientos para la gestión y gobierno de los intereses provinciales y locales (I).

(1) Arts. $49,50,82$ y 83. 
Y en verdad, de poco sirve que un Jefe de ejército dicte las más acertadas disposiciones para el logrode sus legitimos y loables propósitos sinó son secundadas con acierto y buena fe por las fuerzas de su mando; lo propio que sucede cuando el médico prescribe un plan curitativo, si éste no le observa al paciente.

I.

Las Diputaciones provinciales por la naturaleza especial de las funciones administrativas que les están encomendadas pueden coadyuvar eficazmente á la ejecución y cumplimiento de las disposiciones emanadas del Poder central y á fertilizar el campo vasto de la Admistración pública.

Pueden asi mismo contribuir al fomento de la riqueza agricola y pecuaria; y sin perjuicio de la acción del Estado.

Establecer granjas y escuelas prácticas sin lujo de personal y maquinaria; pensiones en favor de los hijos de labradores pobres que reciban la enseñanza agricola, para que después lleguen á ser agricultores y ganaderos inteligentes.

Sostener asilos para la desgracia.

Aumentar el número de caminos y carreteras provinciales, para facilitar salida á los productos y colocación á la clase obrera.

Fomentar las ferias y mercados de producción agrícolas y de ganados. 
Celebrar exposiciones regionales que tan utiles son para dar á conocer los productos agrícolas y estimular á los productores.

Instituir gremios à la virtud y á los adelantos en la agricultura y ganaderia.

Reducir al propio tiempo, en lo posible, las crecidas cuotas de los repartimientos con que para cubrir sus respectivos presupuestos gravan á los pueblos, pues en algunos casos resultan tan sumamente excesivas que el titulado contingente provincial supera con mucho á lo que aquellos pagan á la Hacienda por cupo de Consumos, para lo cual forzosa mente tienen que utilizar el máximun de los recargos que las leyes autorizan sobre las cuotas del Tesoro en la contribución territorial é industrial, sin que estos sean suficientes á cubrir el insinuado cupo ó contigente provincial; resultando asi un nuevo gravamen para los agricultores, ganaderos é industriales, y para todos los que ejercen profesiones del orden civil y judicial, artes y oficios de los comprendidos en las tarifas del reglamento de la contribución industrial.

Estimular con el ejemplo á los Ayuntamientos como superiores gerárquicos inmediatos de los mismos, para la más recta y honrada gestión de sus intereses. 
II.

Pero, si importantes son las facultades concedidas á las Diputaciones provinciales, y en virtud de las mismas pueden y deben adoptar disposiciones encaminadas al fomento de la riqueza agricola y pecuaria, lo son más aún las que están encomandadas á los Ayuntamientos, Corporaciones puramente económico-administrativas; por consiguiente su iniciativa puede ser mayor, y su acción abarcar, si no mayores horizontes, por lo menos más prácticos è inmediatos.

A los Ayuntamientos corresponde:

Reglamentar todo lo concerniente á la higiene y salubridad del pueblo; seguridad personal; beneficencia; riegos; disfrutes y aprovechamientos comunales y guardería rural, por medio de las ordenanzas municipales.

Crear premios para los adelantos que se obtengan en la enseñanza primaria, cimiento firme y base segura de todo progreso.

Organizar las conferencias agricolas para obtener de ellas el mejor fruto posible.

Construir y conservar los caminos de último órden, para la mayor facilidad en el transporte de los productos agrícolas y conducción de ganados.

La creación y sostenimiento de ferias y mercados. 
Establecer prestaciones personales, y facilitar trabajo á los jornaleros particularmente en los meses crudos del invierno.

Regir los cauces del término.

La desecación de lagunas y pantanos.

Corregir la adulteración y la falsificación en los comestibles y bebidas.

Inspeccionar las pesas y medidas, y perseguir las defraudaciones que se cometieren.

Facilitar licencias para construir; debiendo reducir los derechos establecidos al efecto, y en los materiales de construcción, para que los propietarios puedan edificar con mayor facilidad y dar colocación á los obreros.

Suprimir ó reducir los recargos municipales en la contribución Territorial, Industrial impuesto de cédulas personales, y utilizar el relativo á las especies sujetasal de Consumo; siendo muy conveniente y loable la supresión si fuere posible ó en otro caso la reducción de aquellos, singularmente en la parte que afecte á los vinos.

Deslindar y conservar las servidumbres pecuarias.

Mejorar el régimen de los mataderos.

Acordar que el pasto sea gratuito en las dehesas concejiles.

Distribuir los tributos con verdadera equidad y justicia.

Y otra multitud de servicios referentes á empedrados, surtido de aguas, paseos, 
arbolado etc., etc.; por todo lo cual el poder municipal ocupa un lugar preeminente en las instituciones públicas, acerca del que un notable juriconsulto (I) dice: Debajo del poder legislativo, ejecutivo y judicial, hay un cuarto que, á un mismo tiempo público y privado, reune la autoridad del Juez la del padre de familia, y este poder es el poder municipal. Aunque inferior en categoria á los otros tres, sin embargo es mas antiguo que ellos; es sin duda el primero cuya necesidad se hace sentir. No hay aldea que desde el momento de su formación no haya reconocido la necesidad de una admistración interior. Sobre este cimiento los legisladores de los pueblos han levantado el edificio social».

\section{Recompensa que merece.}

Por lo tanto y á fin de estimular importantes y provechosas iniciativas que pueden y aún deben adoptar dentro del círculo de sus respectivas funciones, y diferenciar la pulcritud, integridad y celo de la desidia, corruptela y apatia, convendrá conceder recompensas honorificas á las Diputaciones provinciales y Ayuntamientos en cuya gestión administrativa la moralidad impere y brille en su más alto grado, y que al propio

(1) Mr. Henrion de Ponsey. 
tiempo demuestren mayor celo por fomentar los intereses de las clases productoras (I).

De Norte á Sur, de Oriente á Poniente, en toda España no resuena más que un grito: buena Administración priblica, mas, pero mucho más, se clama por ésta que por las economias.

El campo de una buena Administración irradiará seguramente más fulgores que las perlas y rubies, $\mathrm{y}$ puede producir mucha honra y gloria al Gobierno que con verdadero afán y empeño se consagre á cultivarle (2).

(1) Así como corregir con mano fuerte las trasgresiones que se cometan, y los perjuicios que por apatía $\delta$ intencionadamente se irroguen á los particulares.

(2) En el capitulo signiente precisamos las demás circunstancias inherentes á una buena Administración pública. 



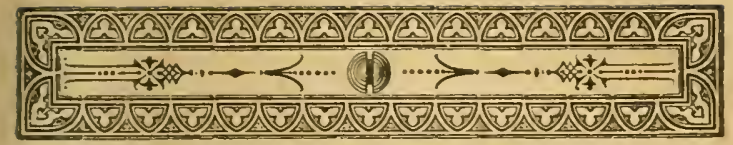

\section{CAPITULO III.}

Deheres reciprocos entre gobernantes $y$ gobernudos.

1. Derechos y deberes.

2. Los tributos son una consecuencia de la necesidad del Estado.

3. Deberes de las clases productoras.

4. Lamentable ligereza ó parcialidad al juzgar los actos de los Gobiernos.

5. Acción que incumbe al Estado.-Verdadera clase para la mejor solución del problema agrícola.

Todos tenemos derechos y deberes: la ciencia de estos tiene por origen la ciencia de aquellos.

Los derechos nos imponen deberes que cumplir, aunque no por ser ciertos é imperiosos dejan de ser dulces y agradables; y en su exacto cumplimiento debe hallar todo buen ciudadano una de las satisfacciones más legitimas y halagüeñas, idéntica à la que 
produce la satisfacción del bien obrar, en el que se apoya y descansa la verdadera tranquilidad de espiritu.

Los principales deberes que el hombre tiene que cumplir son los de servir à Dios y á la pátria. En cuanto á lo primero, nada hemos de decir puesto que corresponde á la enseñanza cristiana; pero sí por lo que atañe á lo segundo porque la pátria impone á todos. sus hijos deberes y sacrificios que no debemos rehuir ni escatimar, y todos debemos. prestarnos á su servicio y defensa tan luego. como sea necesario nuestro concurso y ayuda, hasta derramar nuestra sangre si fuere preciso y repetir las palabras de Salustio: ¡qué hermoso y digno es morir por la pátria que peligra! También debemos ser útiles á la sociedad, otro de los deberes más esenciales del hombre, aún en el que no posea conocimientos cientificos; pues si el saber vale mucho, el ser útil es aun más provechoso; y segun Bostón el ser útil vale más que el saber.

Un buen Gobierno debe consagrar, á manera de sacerdocio, su actividad y su inteligencia al servicio de la pátria inspirándose exclusivamente en el bienestar de la misma: proceder siempre con discreción y prudencia, y si fuere preciso con entereza inquebrantable, pero al propio tiempo con el buen deseo peculiar del padre de familia que sólo aspira 
á labrar la felicidad de sus hijos por los medios licitos y adecuados de que puede disponer con arreglo á sus fuerzas y facultades; considerando á todos de igual clase y condición, sin otra diferencia que la de sus propios merecimientos (I).

No son los ciudadanos para los cónsules, ni la nación para el Rey, sinó al contrario son

(1) Las buenas obras y la buena vida habeis de premiar y honrar más de lo que merecen; porque con esta benignidad quitareis la ocasión de pecar, y la dareis a los hombres de mejor vida, pues en esto la liberalidad y beneficio es lo que aficiona y gana la voluntad.

Y porque el Gobernarlor ha de estar con toda vigilancia en todo inclinadó su ánimo á paz y quietud, no sea tanto que conociéndoos blando se os atrevian, y si alguno se os atreviere, castigarlo luego con moderación, porque si lo haceis fuera de tiempo y sazón dareis más ocasión de pecar.

Como nunca faltan diferencias entre personas principales, procurareis componerlas con brevedad, debilitando con esto la fuerza del odio, y de ninguna manera hagais al uno más respeto que al otro.

Haced este juicio y el que el buen gobernador debe hacer de su propia voluntad todo aquello que quiera que otro hiciese si él fuera su inferior, con lo cual no podreis errar, porque será imposible que siendo vos $\mathbf{a}$ todos padre y conservador, y procediendo con modestia dejen todos de amaros y reverenciaros.

(Instrucciones de Felipe II, á D. Pedro de la Gasca, virey del Perú). 
los cónsules para los ciudadanos y el Rey para la nación. No se han establecido las ciudades para las leyes, sinó las leyes para la ciudad. Asi, los que viven conforme á la ley no han sido organizados para el legislador, sinó este para aquellos, según el filósofo. Aunque los cónsules y los Reyes sean dueños para trazar el camino á los otros, son sus ministros con relación al fin, y el Monarca, incontestablemente el ministro de todos, porque se ha instituido de antemano en su fin y en sus leyes, como la Monarquia para el bienestar del mundo (I).

Los hijos por su parte tienen también la obligación precisa é ineludible de ayudar á los padres con verdadero amor filial; y considerando al Gobierno como á un padre de familia, nos hallamos todos en el deber de ayudarle en cuanto útil, práctico y beneficioso trate de realizar; asi como de recordarle el cumplimiento de sus deberes cuando faltare à ellos.

También debemos considerar que toda Autoridad proviene de Dios, Padre de todas las criaturas, y que el deber de observar el

(1) Del inmortal Toscano Dante Aliglieri en sa tratado De Monarchia mundi al definir los deberes del Papa y del Emperador en el gobierno de los pueblos. 
precepto, aace del orden mismo de la potestad, la cual tiene fuerza de obligar.

«Toda personą está sujeta á las potestades superiores; porque no hay potestad que no provenga de Dios, y Dios es el que ha establecido las que hay en el mundo; por lo cual quien desobedece á las potestades, á la ordenación ó voluntad de Dios desobedece. Por lo tanto es necesario que les esteis sujetos, no sólo por temor del castigo, sinó también por obligación de conciencia (I)».

Jesucristo nos enseñó prácticamente la virtud de la obediencia, reconociendo la investidura de Pilatos, gobernador de la Judea, y sometiéndose á ella explicitamente por estas palabras: No tendrias poder alguno sobre mi, si no te fuera dado de arriba (2).

\section{Los tributos son una}

consecuencia de la necesidad del Estado.

A la vez que la obediencia, todos tenemos el deber imperioso de solventar con la regularidad posible los tributos que los Poderes públicos establezcan y consideren necesarios para atender cumplidamente al fomento de las obras públicas; enseñanza, beneficencia, sostenimiento del clero, ejército, marina, la

(1) Pabl. XIII. $-1 . \circ$ y 2 。

(2) Luc. XXII. -53. 
magistratura y demás obligaciones y servicios del Estado por onerosos y aun detestables que nos parezcan como el impuesto de Consumos, el más irritante y odioso de los que en la actualidad existen, pero mucho más lo fueron otros ya suprimidos (1) y que solventaron religiosamente nuestros antepasados; y en las circunstancias anómalas y difíciles estamos obligados à dar mayores pruebas de patriotismo, por ser cuando los Gobiernos se encuentran en el sensible y espinoso deber de exigir mayores tributos, ya que los grandes males obligan à grandes remedios.

La angustiosa situación económica porque atraviesa la nación, precisa el patriotismo de todos los españoles, y muy particularmente el de las clases productoras.

Las contribuciones y los impuestos son tributos que las autoridades legitimas imponen a la masa de los ciudadanos para atender à las necesidades públicas.

(1) Ábuela; alcabalas, anualidades, bagaje, braceaje, censos enfitéuticos, cientos, diezmo, escusado, fiel medidor, frutos civiles, lanzas, millones, mortajas, pecha, pólvora, primicias, salinas, utensilios y otros. Además existían los derechos feudales y dominicales arcia, cugucia, Ferma de spoli Forzat, llamado de pernada; jorguía y la remenza, las borras, pasos y asaduras, cabalgada, las jobas, tragis y batudas, los laudemios y la partición de frutos. 
En Egipto, uno de los primeros Estados que se constituyeron, y cuyo origen se pierde entre las tinieblas de la oscura noche de los tiempos primitivos, se obligaba á los varones á inscribirse en un registro especial y á declarar su profesión respectiva, à fin de ser útiles al Estado; castigándose con pena de muerte al que prestaba una declaración falsa.

Jalón Campelo, en un luminosisimo tratado sobre Concepto del Impuesto, después de consignar las teorias de Carrera y González, Lozano y Montes, Montesquieu, Miranda Eguica, Pastor, Pierna, Salvá, Garniet, Girardin, Mirabeu Proudhón, Stuar'Mill, y otros distinguidos economistas, todos contestes en cuanto a ser el impuesto un deber de súbdito, y una consecuencia de la necesidad del Estado, y conforme con la opinión de Schaffle respecto á que «el tributo se pide á los ciudadanos en virtud del título de su pública y general obligación de mantener la vida social, sin ninguna mira de utilidad que pudiera conseguir el contribuyente de los servicios públicos, en harmonía con la historia y la ciencia jurídica". añade: partiendo de este criterio, surgen necesariamente en el ánimo dos consideraciones: es la primera que ningún ciudadano, si quiere llamarse tal, debe rehuir el pago del impuesto, sinó antes bien estimarlo zomo deuda sagrada para con 
la nación, para con los demas y hasta para consigo mismo, y que al defraudar al Estado en lo que legitimante debe percibir, aparte de cometerse una acción penable $y$ penada por la ley, se comete en el orden moral el delito de lesa nación, pues el defraudador, á más de quedarse con lo que no es suyo, revela claramente que no tiene patriotismo; y segunda, que los Gobiernos atendida la naturaleza y fines del impuesto, deben no convertirle en medio de explotación del contribuyente, ni siquiera causarle vejámenes innecesarios, sinó pedirle tan sólo lo extrictamente preciso para realizar el Estado su misión, y esto valiéndose de exacciones que si no alcanzan la Economia y la Hacienda, merezcan por lo menos la aprobación de la justicia y la moral.

Nuestra ley fundamental, la Constitución del Estado, con toda equidad y sabiduria, y de conformidad con tan sanos principios y doctrinas, dispone "que todo español está obligado á defender la pátria con las armas, cuando sea llamado por la ley, y á contribuir en proporción de sus haberes para los gastos del Estado, de la Provincia y del Municipio (1)".

Y en efecto los tributos son una verdadera necesidad para la más sólida y perfecta

(1) $\quad$ Art. $3 .^{\circ}$ 
organización del Estado, y para que pueda llenar cumplidamente los importantes fines que le están encomendados. Por lo tanto, es un deber ineludible y sagrado de los ciudadanos contribuir en la parte que á cada uno corresponda, y muy justo dar al César lo que es del César, y di Dios lo que es de Dios (I)》.

También estamos obligados á acudir á los comicios para conseguir representen los distritos personas de arraigo y de reconocida jlustración que se propongan solamente atender al remedio de las necesidades sentidas en los distritos ó circunscripciones que representen; debiendo huir de falsos halagos y mentidas promesas, y muy en particular de los que abriguen ideas de mando y dominio, ó de medros personales, ajenos por completo á los intereses de los electores que les concedieron sus sufragios (2).

Deberes de las clases productoras.

Además, las clases productoras, comprendiendo sus propios intereses, sin perjuicio y aparte de la acción que incumba á los Poderes públicos, pueden hacer mucho para la mejor sulución del gran problema que nos ocupa, y de otros relacionados con el mismo, evitando asi muchos inconvenientes, por ser

(1) Nat. XXII.-21.

(2) En la Parte 1. ${ }^{2}$, Cap. VII. nos ocupamos con mayor detenimiento de tan importante particular. 
las que se hallan mas en contacto con las clases obreras. Aun cuando las reglas de uua buena educación aconsejan que medie alguna distancia entre amos y criados, conviene no olvidar que los que prestan sus sercicios merecen consideración y aun cariño, y que se les recompense con la parte que en conciencia les pertenezca; y en todos aquellos casos que posible sea con cierta participación en los productos que obtengan los propietarios, para compartir equitativamente las ganancias ó pérdidas que resulten del cultivo de los campos, según fuere más conveniente á los intereses recíprocos de unos y otros, y á lo que aconsejen y requieran las circunstancias

- especiales de cada localidad, tratándoles como de familia; porque es sabido que cuando el obrero del campo trabaja con gusto y buena fe, las labores resultan más fecundas y provechosas, y para conseguir además de la clase obrera que en lugar de ser un torrente devastador que lo arrase todo, sea mansa y caudalosa corriente que todo lo fecunde (I).

(i) Cuando segares las mieses en tu campo y dejares alguna gavilla olvidada, no volverás á recogerla, sinó que dejarás que la tomen el extranjero y el huérfano y la viuda, para que te bendiga el Señor Dios tuyo en todas las obras de tus manos. (Deuter. cap. 24),

Ni en tu viña recogerás los racimos ni los granos que se caigan, sinó que los dejarás para que los recojan los pobres y los forasteros. (Levit. cap. 19). 
El obrero por su parte ha de ver en su amo el constante protector de sus intereses y derechos, considerándole como jefe de familia á quien acudir en sus necesidades, y con quien compartir los sinsabores y alegias de este valle de peregrinación y de tránsito.

Las mismas clases productoras, en particular las mas acomodadas de la gloriosa nación de los Recaredos, de los Pelayos, y de los Fernandos; de la gran nación española en cuya memoria existen los recuerdos inmortales de Covadonga, de Lepanto y de Granada, si santificaran las fiestas y consintieran à sus obreros el descanso en los dias festivos, tan necesario para reponer las fuerzas, procurando que todos cumplieran el precepto de oir misa y demás prácticas cristianas, tendrían mucho adelantado para la consecución de tan importante fin, y para moralizar las costumbres; pues la religión cristiana es el limo que fertiliza la tierra y el agua que riega los campos de la sociedad, vigorizados por el hermoso sol de las creencias religiosas: es la que modera los sentimientos y nos enseña á despreciar el oropel de la tierra, á sufrir los dolores de la vida, y á perdonar y aún á rogar por nuestros enemigos (I).

(1) Y si en España no han arraigado las teorías de Kant, Fichte y Hegel, y otras aún más exaltadas, 
En una casa de labor de las más importantes y mejor organizadas que conocemos en España (I) se sigue tan piadosa costumbre; y aun durante la recolección de cereales y vendimia se suspenden las labores por precisas y urgentes que sean, para que ei personal empleado en las mismas, y los demás obreros y pastores no falten en tales dias á tan sagrada obligación, sin que por ello se los descuente cosa alguna de sus haberes respectivos. Así lo establece el reglamento de la casa (2) y asi se observa fielmente; y en las demás épocas del año se prohibe el trabajo en los días festivos, pero se abona el jornal á los braceros, los cuales cumplen con la mayor oportunidad los deberes de la Iglesia; recreándose después en diversiones licitas y honestas, sin ofender la moral ni las buenas costumbres, y hasta en sus diversiones impera la mayor concordia y armonia. Durante el trabajo procuran cumplir como buenos cristianos, en justa recompensa ó indemnización al salario que reciben.

El descanso dominical es propio de los paises cultos. El Reichstag alemán aprobó

se debe principalmente á la educación cristiana que por fortuna impera en nuestro país.

(1) La del Sr. D. Epifanio de la Gándara, en Arroyo (Valladolid).

(2) Tit. VIll, cap. $2 .^{\circ}$ 
por muy considerable mayoria la ley del descanso en el servicio de correos, sin otra excepción que la referente à la correspondencia internacional. Gladstone el haber logrado tan larga vida lo atribuye al descanso dominical, en cuyo día no se ha ocupado jamás ni aún de los importantes asuntos de Estado, y asegura que por más que se prescinda del precepto divino, le recomiendan eficazmente las conveniencias humanas. $\mathrm{Y}$ en Nueva-York, populosa ciudad democrática y federal, se prohibe hasta vender el pan los domingos, bajo penas muy severas.

Lamentable ligereza ó parcialidad al juzgar los actos de los Gobiernos.

La ligereza y apasionamiento con que se censuran los actos de los Gobiernos, hacen incurrir casi siempre en errores y apreciaciones lamentables.

Pocas veces se juzga con verdadera imparcialidad la conducta del Gobierno. De su prudencia se dice que es cobardia; la puntual observancia al precepto constitucional, que es falta de iniciativa; su mesura, insuficiencia; à la circunspección, miedo; sus sacrificios, de egoismo, y su desinterés, vanidad. Si permanecen poco tiempo en el Poder, se dice que es ineptitud; si mucho que parece herencia; de sus sentimientos caritativos, que es hipocresia, y que imitan à Juan 
de Robres. Muchos olvidando el antiguo refran Otro zendrá, que bueno me hará; dicen. que con los Gobiernos, sucede algo parecido. á los tres reyes que conoció la vieja del cuento, que el segundo era peor que el primero, y el tercero peor que los otros dos; que en las. crisis ministeriales todo se reduce à un cambio de personas; y algunos, los de mejor voluntad, suelen decir que el Gobierno se gasta: en el poder como si fuera de blanda cera.

Lo propio sucede con respeto á las demás personas que representan el principio de Autoridad, y funcionarios públicos.

Cada cual se considera con derecho á censurar sus actos, tergiversándolos de la manera que mejor le place, aunque profano y sin conciencia de sus criticas y aseveraciones, como el célebre estudiante del arquitrabe; y á dar lecciones como muchos aficcionados á presenciar las corridas de toros, que las dán siempre desde la barrera, pero nunca en el redondel í la cabeza del toro (I).

(1) La condición de nuestra flaqueza humana nos hace ver muchas veces imperfecciones donde hay méritos, y los defectos ajenos antes que los propios; asi como también parecernos corregir fácilmente lo que otro ha hecho, porque resulta casi siempre más sencillo ermendar que edificar.

También es frecuente, según Ioliere, que critiquen á otro, aquel!os cuya conducta se presta más á la crítica, como asímismo aquel que menos sabe y que, 
Sin investigar préviamente si los males que se pide al Estado que alivie son fruto de condiciones personales ó dependen de las condiciones de la vida, se cree que el Estado debe remediarlos. Cada partido, cada interés considera lo que a él afecta como lo más esencial y apremiante del mundo. Lo más frecuente, es que el bien público se oculte bajo un manto económico; se hace al Gobierno responsable de los sufrimientos y de las privaciones de los pobres, de la falta de trabajos lucrativos, de las inundaciones y de las malas cosechas. De ahi resulta un sencillo efecto reflejo: por una parte los Gobiernos, animados de un buen deseo por el pretendido bienestar de los pueblos, reivindican como de su propia obra todos los resultados favorables de la beneficencia oficial y de su

por consiguiente, menos motivos tiene para dar lecciones, al que convendria tener presente el Nosce te ipsum del gran Sócrates, y si es que se conoce á sí mismo, se persuadirá entónces de que aún cuando esté poseido de los mejores deseos, no podrá siempre llenar su cometido con la perfección que debiera, ni se evitará por eso de juicios infundados y contradictorios. Además, no debe olvidar el sábio consejo del famoso Trueba: Critique el sabio punzante: -que es útil crírica sábia, pero me dá mucha rabia que critique el ignorante. - Si me critican un canto -y quieren que no me pique, sepa aquel que me critique;siquiera hacer otro tanto. 
paternal solicitud; por otra parte, el pueblo, amoldado à la tutela, echa sobre la espalda de los Gobiernos todos los incedentes desfavorables, dañosos ó desastrosos de la vida. económica, todas las crisis y todas las desgracias. Nadie piensa que él puede ser causante de sus propios males. De este modo, derechos y deberes públicos caen en un estado de confusión permanente ( $\mathrm{r}$ ).

Asi sucede en efecto; nadie se considera causante de sus propios males, y de todos: éstos, quiere hacerse responsables á los Gobiernos.

Algunos en su constante afán de censurar, les culpan de que ocurran los terribles. terremotos, las inundaciones, pedriscos, heladas, sequias, etc., como si el hombre á pesar de su saber y laboriosidad, sus buenos propósitos y deseos, fuera capaz, en su pequeñez, de oponerse contra la poderosa acción de los Elementos.

Cierto que ya se conocen medios sencillos. para precaver á las plantas de los efectos. destructores de las heladas, como el de crear por el humo nubes artificiales al aparecer la luz solar, $y$ otros diversos adecuados al objeto; contra el pedrisco, el para-granizo; y contra las sequias, además de los canales.

(1) F. Holtzendorff, en su obra Los Fines del. Estado. 
de riego, máquinas de elevar aguas, etc., el producir lluvia por medio de las explosiosiones; pero este último medio no está aún bien comprobado, y los primeros ya resulten más ó menos costosos, necesario es reconocer que su aplicación corresponde más al propietario que al Estado.

\section{Acción que incumbe al Estado.}

Otros medios hay en verdad que corresponden al Estado y de los que vamos á ocuparnos brevemente $\epsilon n$ este lugar, del que conceptuamos el más importante, y la causa primorial del malestar general que aqueja al pais, y à la que más que á los Tratados y Presupuestos, obedecen las quejas, disgustos y lamentos que se oyen por doquier.

Un tratado de comercio establecido con buenas bases para ambas partes contratantes (r), es seguramente beneficioso para la producción nacional; pero un Tratado no es una panacea como tampoco lo es un Presupuesto en que aparezcan nivelados los ingresos y gastos, y menos si unos y otros no resultan con verdadera equidad.

La mayor recaudación puede consistir en esquilmar más á los contribuyentes; asi como

(1) Lo cual es dificil, como expondremos en la Parte 1.', cap. V. 
el gastar menos puede obedecer à producir menos.

Tanto los ingresos comolos gastos son sintomas que demuestran la prosperidad de una nación; pero no remedios eficaces para combatir los males que ocasionan su ruina.

Conviene, pues, penetrar en lo más hondo, en las profundidades de la realidad; $y$ los remedios deben abarcar más, y ser de mayor eficacia.

La viciosa y complicada organización de todo el sistema administrativo, (que nadie hasta hoy se ha atrevido á reformar) ocasiona daños incalculables, y cohibe, axfisia y mata toda iniciativa individual, todo gérmen de vida, todo proyecto fecundo, toda idea elevada y patriótica.

No hay, ni puede haber en España iniciativa alguna para las grandes empresas; no puede haber invenciones de ningún género, aspiraciones nobles, ni nada que signifique fomento de riqueza, desarrollo, vida y progreso, porque en vez de recompensar el mérito y estimular toda idea provechosa, Ia Administración, con sus pesadas anclas de hierro, todo Io paraliza y enerva; es el lazo corredizo que estrecha y oprime con fuerza vigorosa, y todo mueve al fin bajo el peso de su fuerte losa de plomo.

Segun todos hemos sabido por la prensa periódica, en Subsecretaría del Ministerio de 
Hacienda, existian en 1894 , sin resolver, 17.438 expedientes.

No es nuestro ánimo dirigir inculpaciones á nadie, ni averiguar el origen de tal retraso; pero tenemos que partir del hecho para pedir que se remedie el mal, porque este dato que conceptuamos auténtico y por si solo harto elocuente, es una prueba bien palmaria que revela el deplorable estado de nuestra organización administrativa.

iii 17.438 expedientes sin despachar!!!

iY solo en un Ministerio! Quisiéramos saber el número exácto de los que se hallan en el propio caso en los ocho Ministerios restantes, Gobiernos civiles, Delegaciones de Hacienda, Diputaciones provinciales, Ayuntamientos y demás centros y oficinas de España; y también quisiéramos poder apreciar con la mayor exactitud posible los muchos miles de millones perdidos ó paralizados que representan tantos expedientes, esperando la recomendacion eficaz que los facilite el paso por las estrechas mallas de la minuta, el informe, la cópia ó el beneplácito del cacique, la ojeada de los subjefes, el turno para la firma que nunca llega, ni la prodigiosa voz que à cada uno le diga: levántate $y$ anda.

¡Que impulso se podía haber dado á tan enormes capitales en los meses ó años que se encuentren inactivos! ¡A cuantos millones 
ascenderán los perjuicios seguidos á los interesados con tales demoras, y con tantos permisos, proyectos, recursos, incidencias alzadas, etc! ¡Y á cuánto las pérdidas para el fomento de la agricultura, industria, comercio y demás fuentes de riqueza!

No es de extrañar que la mejor voluntad se entibie y el ánimo más decidido y enérgico decaiga ante el cúmulo de obstáculos tan insuperables para realizar los más levantados propósitos. No es, pues extraño que los grandes génios, las iniciativas más vigorosas desistan de las ideas más nobles y de toda aspiración elevada y patriótica.

En cambio es digno de admiración y acreedor á toda clase deconsideraciones todo aquel que emprende una explotación agrícola é industrial; que consigue la apertura de una carretera; estudia la de una via férrea, ó cualquier otro proyecto que signifique fomento de riqueza, elevación de nuestro crédito, facilidades de comunicación para los pueblos, trabajo al bracero y bienestar para todos; ese si que es un héroe, un esforzado adalid, un valeroso atleta, un nuevo Colón, que despues. de haber luchado valerosamentecon fé, entusiasmo y denuedo en los procelosos mares de nuestra administración contra las tempestades, sirtes, escollos y arrécifes, consigue arribar á puerto seguro, y descansar en hospitalaria playa de los sinsabores y sobresaltos. 
de su arriesgadoviaje, llevando con su saber, patriotismo, abnegación y paciencia, la savia, animación, movimiento, vida y copiosos raudales de luz, alli donde antes solo habia pobreza, aridez, catalepsia, marasmo, quietud, malestar y tinieblas.

También sabemos por la prensa, que en Junio de 1895, existían nada menos que 100.000 cuentas atrasadas y sin fallar en el Tribunal de Cuentas, y que para fallarlas ha sido necesario crear nuevas plazas de Ministros.

Y ¿đe cuándo serán esas cuentas? ¿Cuál su procedencia? ¿Cuáles lus motivos verdaderos de la falta de despacho? ¿Existirá ya alguno de los muchos que acaso resulten responsables?

Tampoco es nuestro ánimo investigarlo, ni si hubiera sido más conveniente el nombramiento de un jefe de negaciado con algunos oficiales y auxiliares probos, inteligentes y laboriosos que el de Ministros; sino ủnicamente consignar el hecho, porque también dice mucho acerca del estado de nuestra Administración.

Las disposictones dictadas para descubrir la riqueza oculta, obligan al pago de contribuciones atrasadas, multa é intereses de demora al contribuyente que no tiene amillarada toda la riqueza; pero si se comprueba que se le exige y paga más contribución que 
la que le corresponde, entónces no se le concede derecho al reintegro, ni aún á que se rectifique el error para en lo sucesivo.

Tampoco se tramitan los expedientes sobre condonación de contribuciones, ni las reclamaciones fundadas en haber disminuido la riqueza imponible designada á los pueblos por cupo contributivo.

Las bajas de la contribución industrial no se despachan con oportunidad por justificadas que sean, cuyo proceder origina apremios y perjucios á los interesados.

Cuando algún particular se propone emplear sus capitales, crear y desarrollar nuevas industrias, tropieza, como ya hemos afirmado, con multitud de trabas y obstáculos de la impertérrita burocracia, y las leyes vienen siendo letra muerta en nuestras costumbres administrativas.

Por lo tanto, procede y es de urgente necesidad un deber del Estado simplificar $y$ moralizar la organización administrativa, para que los procedimientos sean siempre breves y sencillos y resulten en extricta justicia, haciendo responsables de los retrasos y negligencias à los funcionarios que resulten morosos ( 1 ).

(1) En la Parte 4.' ó de Nuevos Ingresos, indicamos algunas reglas á tal fin. 
Pero además es de reconocida urgencia moralizar también la Politica. Asi lo reclaman de consuno como de necesidad imperiosa las. ciencias, las artes, la industria el comercio y muy particularmente los agricultores; reconociendo que cuando la Política deja de ser la ciencia de gobernar, para convertirse en ideas mezquinas y personalísimas, y las ambiciones y egoismos son antepuestos al interés general de la pátria, entónces resulta el caos, una verdadera anarquia que aunque mansa produce efectos funestísimos, porque mata y aniquila cuanto toca.

En muchos pueblos agrícolas no se conocen las teorias anarquistas, pero en cambio se conocen ciertos abusos, desmanes é injuscias que influyen con mayor eficacia que aquellas, en particular cuando los que se hallan colocados a gran altura en vez de evitarlas ó corregirlas las prestan su apoyo y protección.

Y ¿de qué manera se habrá de moralizar la Politica?

Por medio del ejemplo.

El buen ejemplo -dice Valerio Máximo- es lo que más aprovecha á las buenas costumbres.

Con el ejemplo de arriba principalmente, es como se salvan situaciones extremas.

Decimos que con el buen ejemplo, porque como la palabra estan susceptible de engaño, 
no se la dá con facilidad entero crédito, y el ejemplo en cambio no puede engañar, y es el que más edifica, conmueve y persuade; y por eso se le concede en todos sentidos tanta autoridad y trascendencia.

Os he dado ejemplo -dijo el Salvador á sus discipulos- para que hagais vosotros lo que yo be hecho (I).

La virtud del buen ejemplo es también indispensable para que se respete y conserve incolume el principio de autoridad, muy necesario áun en los pueblos más libres é jlustrados; y que su más firme y valioso apoyo consiste seguramente en la fuerza del buen ejemplo de quienes mayor potestad ejercen y representan.

Un Gobierno, que al convocar las Córtes demuestre la neutralidad más absoluta en las elecciones para conocer la voluntad de los electores, que garantice la libertad del sufragio, la verdadera sinceridad electoral, como también la de los candidatos, en una palabra, que cumpla la ley en todas sus partes, daria en verdad un buen ejemplo, á que por desgracia no estamos acostumbrados los españoles; con esto basta, pero no para decirlo solamente desde las columnas de la Gaceta, y después comunicar órdenes tan reservadas como enérgicas y apremiantes en busca de

(1) Joan XlII-lo. 
ciertos resortes mágicos para conseguir como siempre sucede los resultados que todos sabemos, sino dando ejemplo, castigando con todo rigor à los Gobernadores y demás funcionarios que se entrometan en asuntos electorales.

Asì se verian cláramente los deseos del pais, y sus representantes serian la voluntad genuina, la expresión fiel y sincera del mismo, la agricultura tendria mayor representación, porque esencialmente, agrícola es la casi totalidad de la nación. Los candidatos electos, desligados de todo compromiso con los partidos políticos, atenderian mejor à las necesidades de la ración, al fomento de la riqueza agricola y pecuaria.

¿Cuándo veremos un solo caso siquiera de neutralidad extricta por parte del Gobierno en las elecciones, y que los candidatos ministeriales sean en su mayoría derrotados?

¡Qué mayor gloria podia esperar, particularmente el Ministro de la Gobernación!

Pero las leyes no solo no se cumplen, sino que se falsean y prostituyen impúnemente. Las cuentas negras, expedientes por pastoreo abusivo en los montes públicos, de multas impuestas y no realizadas, alcances, reclamaciones, denuncias; todo entónces se evidencia, todo se exhibe, y se patentizan las mas sérias responsabilidades. ¿Y qué sucede? Lo que ya se tenia prejuzgado. Todo durante 
el periodo electoral tiene fácil arreglo; basta sanar enfermos crónicos, y resucitar muchus lázaros, si es preciso; y como por arte de mágia, salen siempre triunfantes los candidatos adictos al Ministerio encargado de dirigir la máquina electoral, ya sean conservadores, liberales ó demócratas; ya aparezcan las actas cubiertas en forma, llenas de raspaduras ó en blanco; bien si las urnas son de cristal, como si son de barro, ó de madera, el resultado es siempre el mismo.

Más cuando después de haber relegado al olvido tantos incidentes, ya consideraban muchos arreglados satisfactoriamente sus negocios, surgen nuevos cambios políticos, y con ellos nuevas elecciones, y otra vez las mismas escenas se repiten, y se adicionan con las faltas, abusos, y negligencias habidas desde la elección anterior; pero como ya se sabe el remedio, aún cuando el resultado sea solo provisional, la aplicación es bien sencilla.

De manera que el sufragio universal ¿qué efectos produce en la practica? ¿No es una farsa ignominiosa, una mentira indigna, un engaño bien patente, y una burda comedia en la que los electores representan un papel ridículo en extremo y hasta denigrante?

De no imperar en su ejercicio la sinceridad y la pureza ¿no sería más noble y más digno y honrado que al pais se le privase del 
derecho del sufragio, y que el Gobierno nombrase á su voluntad cada candida to como nombra los Senadores vitalicios, aún cuando las Córtes apareciesen compuestas de yernos, tios y sobrinos de los Ministros, que esculpir en las tablas de la ley derechos que después han de ser conculcados y prostituidos como todos sabemos?

Asi al menos procedería con más franqueza, se sabría quiénes eran los responsables que ahora se escudan con el Cuerpo electoral, y se evitarian luchas, intrigas, ódios y rencillas que dejan en pós de si las elecciones.

De aquí el origen de muchos males que el pais lamenta y à que principalmente obedece el estado de anarquía en que viven muchos pueblos.

Por otra parte, qué interés han de tener muchos Diputados y Senadores electivos por los distritos que representan, cuando saben que más que á la voluntad de los electores, y aún á sus propios méritos, deben la credencial y representación que ostentan á la voluntad del Gobierno.

$\mathrm{Y}$ no se diga que al cuerpo electoral corrresponde purificar el sistema, despreciando falsas promesas, porque sabido es que aquél viene á ser lo mismo (perdónesenos el simil), que un organillo de manubrio con piezas variadas, que siempre toca aquella que coloca 
quien le maneja; y el pueblo, en particular agrícola, que trabaja paga y calla, recibe io que le dán, y con lo que encuentra se conforma.

¿Cómo sino los cambios tan repentinos y radicales que con dolor se notan, particularmente en los pueblos, cuando llegan las elecciones?

¿Por qué triunfan siempre los candidatos ministeriales?

Con respecto á la aplicación de las leyes el cuadro es aún más doloroso. Ya se prejuzga el resultado de cualquier asunto, más por la influencia que por la razón que asiste á los interesados; pues también sucede, que para casos iguales se dictan resoluciones diametralmente opuestas. Cuando los patrocinadores de abusos, arbitrariedades é injus. ticias no pueden torcer, ni barrenar la ley, apelan al sistema del retraimiento; y los meses y aún los años transcurreñ sin que se resuelvan en ningún sentido multitud de alzadas y reclamaciones.

Para el ejercicio de cargos públicos no siempre se nombra á los de más aptitud, honradez y laboriosidad, sinó á los que tienen mejores recomendaciones; sin que después les sea posible hacer otra cosa que la voluntad de aquellos á quienes deben su nombramiento, porque tienen sobre su cabeza una espada de Damocles que los amenaza 
sin cesar con una muerte repentina; siendo otra de las causas que motiva el desquiciamiento en la marcha administrativa, la movilidad constante de los funcionarios públicos y la poca ó ninguna consideración que los políticos guardan à los empleados entendidos, laboriosos y de probidad reconocida.

Hasta en la exacción de tributos hay diferencias bien notables en perjuicio de la equidad y del Tesoro público, pues si se realizasen oportunamente cuantos derechos corresponden á la Hacienda en todos los elementos tributarios, seria un hecho real y tangible la nivelación de los presupuestos, evitando dificits considerables todos los años; más por efecto de la mucha tolerancia para quienes disfrutan del favor oficial se consiente, en particular á los Ayuntamientos, que transcurran años y años sin solventar lo que por impuestos de consumo (I) de cédulas personales, de sueldo y haberes de empleados, 20 por roo de la renta de Propios, etc. adeudan á la Hacienda, mientras se apremia sin consideración alguna á los más dóciles y á los más

(1) A mediados de Diciembre anterior, había siete pueblos en una sola provincia sin haber pagado al Estado ur céntimo por consumos durante los cuatro úllimos años, á pesar de que dichos pueblos cobraron el arriendo, y mushos que nada pagaron en el año económico pasado. 
solicitos por el puntual y exacto cumplimiento de sus deberes, para los cuales no hay premio ni descuento alguno, ni la menor recompensa; cuando más alguna frase laudatoria que la modestia rechaza; y en cambio á los malos pagadores, á los que desatendiendoel precepto de la ley, no se sabe qué han hecho de sus caudales, ó si los han invertido en servicios diferentes que á los que fueron destinados, en vez de tomarlos estrecha cuenta de la inversión de sus fondos y exigir en cada caso las responsabilidades que procedan, se los premia con el perdón de un 50 y 70 por ıoo, (según la época de los débitos) de las cantidades que debieran haber pagado, como así lo patentiza la ley de 16 de Abril de 1895 sobre perdones y moratorias, y otras análogas que se habian publicado antes de la indicada fecha; dando lugar á que los mismos precisamente que debian ser responsables de sus faltas y omisiones, lla. men incautos y cándidos, ó por otro nombre tontos á los que se han esmerado por pagar con la mayor puntualidad y cumplir fidelísimamente en el desempeño de su respectivo cometido.

Todavia es más vergonzoso y lamentable lo que sucede respecto á la contribución de sangre. ¡Cuántos infelices habrán sido arrancados del regazo materno para llevarlos á derramar su sangre yexhalar el último suspiro 
en paises insalubres y lejanos, peleando contra los enemigos de la pátria, y sufriendo los rigores del clima, no por suerte legal sino por amaños y arbitrariedades de que son víctimas los más inocentes, los más patriotas y honrados, y que de haber sufrido sorteo los exceptuados de él indebidamente (I), tal vez les hubieran correspondido los mismos números con que aquéllos fueron á recibir la muerte lejos de su pais, y de los cuidados y afecciones de familia! Y ¡cuántas lágrimas habrán derramado infinidad de madres, cuyos hijos, pedazos de su corazón, sangre de su propia sangre, idolos adorados desu alma, criados á costa de muchas privaciones y trabajos, les fueron arrebatados por la misma circunstancia, sin tener el triste consuelo de cerrar sus párpados inertes, dar el tierno $\mathrm{y}$ último ósculo de despedida, y sin saber siquiera el sitio donde reposan aquellos restos queridos é idolatrados!

Es bien notorio que ha habido provincia en España que solo ha dado nueve soldados para el reemplazo de I894. En algunas poblaciones se apela á la declaración de prófugos ó á declarar cortos de talla á mozos que midiéndolos después aparece que han crecido ciento ó doscientos milimetros más,

(1) En la Parte $3 .^{2}$ proponemos la reforma que conceptuamos más eficaz, conveniente y equitativa. 
y a exceptuar por inútiles á muchos que si fueren reconocidos posteriormente resultarían aptos para el servicio. A pesar de que la prensa se ha ocupado de los escándalos cometidos, no sabemos que se haya aplicado el oportuno remedio; por lo cual los autores y patrocinadores de tan vergonzosos abusos, quizá repitan con fruición las palabras que el Arzobispo virrey pronunció en Guatemala al recibir al embajador español encargado de moralizar aquellos dominios cuando le dijo: Señor, aqui no hay justicia, no hay órden, no hay administración; pero tampoco conviene que haya esas cosas.

El mal no es nuevo por desgracia, sino bastante crónico, pues hace ya mas de medio siglo que un notable repúblico (I), á propósito del caciquismo, decia en el prólogo de una de sus obras (2), que el derecho administrativo ha quedado convertido en un montón de escombros, bajo cuyo peso gimen todos los españoles que no gozan el favor de quien á la sazón gobierna; y que en España ha llegado á ser casi un apotegma que las leyes y los reglamentos solo se han hecho para servir à los amigos.

Asi sucede en efecto hasta en las cuestiones mas insignificantes, para los amigos la

(1) Posada Herrera

(2) La Beneficencia Pública. 
gracia, para los adversarios la juslicia, la voluntad del caciquismo imponiéndose en todo (I).

En los pueblos principalmente es donde más se tocan las consecuencias y donde más se sienten los efectos perniciosos del caciquismo, á los que desciende, degenerado por afecciones morbosas como granizo dañino sobre feraz campiña, impulsado por violenta tempestad; y en los cuales adquieren mayor desarrollo las pasiones que anidan en el fondo del corazón humano (2).

Sin embargo, preciso es reconocer que en algunos pueblos más que á los caciques de provincia ó de distrito, hay que culpar á los caciques de bajo vuelo de las mismas localidades; á los que en lugar de imitar al águila para remontarse á las alturas do se respira

(1) La pobrísima concepción de lo que es la política arraigada en el ánimo de muchos sujetos que la practican constituye, sin duda alguna, uno de los ma. yores males de nuestra nación. (Arruche.-Cuaderno 3. de la revista internacional Pro Pátria).

Muchos opinan que la peor de las anarquías es la corrupción administrativa, y la causa más poderosa de la decadencia de los pueblos.

(2) Aun en aquellos que aparentan serenidad y calma, pres el rescoldo en vez de apagar el fuego lo mantiene disimulado y oculto y el rio cuanlo más lleno -oculta mejor su fondo-y á medida que es más hondo-aparece más sereno. (Lopez de Ayala). 
un ambiente oxigenado y puro, imitan al reptil venenoso para arrastrarse por cieno $y$ lodo.

En la inmensa mayoria de las Corporaciones municipales existe buena fe, hidalguia, deseo de acierto, y la elevación del corazón suple á la cultura del entendimiento para el. desempeño de cargos que no ocasionan más que molestias y sendos disgustos.

En los pueblos cuando la administración de la justicia está en manos de personas instruidas, animadas de buenos propósitos; iqué: mayor dicha! nada falta, todo marcha á maravilla y todos viven bien, no obstante el rigor de las leyes y la poca tolerancia de la Hacienda para la exacción de tributos, y para el cumplimiento de algunos servicios difíciles de realizar por la escasez de personal y de recursos (I); pero cuando aquella lo está en manos de personas ignorantes, de aviesas intenciones y sin idea alguna elevada, entónces es el reverso de la medalla; todo cambia, todo

(1) Lo cual origina en muchos casos el abandonode los cargos concejiles por parte de las personas acomodadas $y$ de honradez, porque en tales ocasiones quien más tiene, más pierde, y sólo se muestran propicios al desempeño de los que no suelen tener mucha afición al trabajo campestre y los que nada tienen que perder, con lo cual dicho se está el interés que han de demostrar por favorecer la agricultura y la ganadería $y$ 
se troca y todo varia de aspecto y resultados; pues á pesar de su escasa instrucción, suelen tener aquellos una profunda filosofía y una lógica superior á todos los estudios para inventar medios, pretextos, y procedimientos con el objeto de ocasionar daños (I).

La consecución de ciertos derechos políticos es lo que menos preocupa en algunas localidades; la politica viene á ser un mito, un pretexto y solo se atiende á ella para que favorezca ciertos intereses particulares, ydeterminados fines bastardos (2).

aun crando los cargos de Concejales, segun la ley municipal son honoríficos, gratuitos y de carácter económico-administrativos, algunos entienden que el nombre no bace á la cosa como dice el adagio francés, y ejercen de la manera que su saber y entender, 6 su capricho los dicta.

(1) Algunos no saben de lo que es capaz un cacique rural con vara, el que á manera de señor feudal moderno y parodiando á su modo la frase del monarca francés el Estado soy yo, hace cuanto se le antoja, sin que haya quien ponga coto á sus arbitrariedades: Ya dijo el historiador Lafuente que nada hay tan peligroso como la autoridad en manos de quien no sabe ejercerla.

(2) Prueba de ello, es que en alguna elección sucede que ambas paruialidades se proponen emitir sus sufragios a favor de un mismo candidato, $y$ en vez de aprovechar tal coyuntura para establecer la unión y perfecta harmonia entre todos y trabajar unísonos en pró de sus mútuos intereses y de cuanto concierne ála 
No es ya solamente que se cometan abusos en la imposición y exacción de tributos, prestaciones personales, alojamientos y demás servicios, ni que se cometan arbitrariedades, sin otras razones que las que invocaran Atila y Alarico, jaztándose después de tales fechorías; no es todo esto con ser mucho lo más importante ni que cada parcialidad tenga médico, veterinario, herrero, tienda, cantina diferente, etc., y si estuviera en sus atribuciones tendrian tambien párroco, maestro y sacristan para cada partido, ni que en los bailes juegos y aun en las fiestas religiosas se diferencien los de uno y otro bando; lo mismo los recinos que los jóvenes de uno y otro sexo; sinó que hasta de las diversiones se promueven motines preparados de antemano, insultos, intrigas, falsedades y aun crimenes tan

agricultura, le dicen los de un bando que son amigos suyos y se proponían servirle, pero en atención á que sus enemigos tienen el mismo propósito, que ellos por su parte harán en la elección toda la contra que puedan. También suele ocurrir que para demostrar los que disponen de mayor número de sufragios, y los que trabajan con más decisión en favor de un mismo candidato, le remiten la lista de los electores adictos a cada partido, consiguiendo, que el nombre de alguno de aquellos figure en una y otra lista; con lo cual, lejos de favorecer, perjudican á quien se proponen servir, porque algunos electores se retraen para evitarse de compromisos. 
inauditos, como el de incendiar mieses, edificios, destaponar las cubas, para que se derrame el vino y no lo pueda utilizar el dueño, etcétera, demostrando los autores de tan inicuo proceder que no tienen educación ni está arraigado en sus corazones el santo temor de Dios, y el amor que se debe profesar al prójimo: y que al perseguirse con tal saña y crueldad imitan á los Nerones y Dioclecianos cuando perseguian á los héroes del cristianismo.

También es necesario reconocer que si se mira el origen de tales disturbios, crimenes, ódios y rencores, se verá que la elección de tal ó cual época ocasionó algunos sinsabores y disgustos, y que en vez de dulcificarlos ó cortarlos de raiz desde sus comienzos, fueron creciendo como la mala yerba, alentados por el beneplácito y là protección que hallaron en otras esferas. Por lo tanto un gran bien se haría á los pueblos si en vez de servir á los amigos, como sucede casi siempre, con razón ó sin ella, se atendiera solamente la razón y la justicia, sin mirar para ello matices ni procedencias; así se evitarian muchos abusos y desmanes, y se lograria con mayor facilidad implantar en aquellos el benéfico ramo de oliva, para que á su sombra se dediquen todos sus habitantes con más gusto y tranquilidad al cultivo de los campos. 
Además de amparar la razón y la justicia conviene evitar molestias á los contribuyentes, y proceder con equidad en la exacción de tributos: que no haya tolerancia para los compradores de los bienes llamados nacionales y algunas Corporaciones privilegiadas y rigor excesivo para otras con menos fortuna, así como también para los contribuyentes que no pueden pagar sus cuotas con la puntualidad que desean por efecto de las malas cosechas, ó por no tener salida sus productos; debiendo el Estado usar de la misma puntualidad y rectitud para pagar que para cobrar, señaladamente con las entidades ó personas modestas por su posición, en lugar del sistema cobra y no pagues que somos mortales, que más que norma de conducta ha venido siendo norma legal de la Hacienda que apremia y cobra á raja-tabla, principal y recargos (I) mientras que para el Estado no hay apremios, embargos, ni demoras: en todo aplicando el principio quia nominor leo; y si hasta para hacer un ingreso en favor del Tesoro hay dificultades, para cobrar se necesita toda la fe de un creyente y la paciencia de un santo, que en ocasiones obliga á exclamar con

(1) Si bien con las excepciones lamentables ya insinuadas. 
el célebre tribuno romano: Quosque tandem, Catalina, abutere patientia nostra? (I).

También es necesario el ejemplo para el fiel y exacto cumplimiento de las leyes, ya que para barrenarlas y eludirlas se inventan motivos a cual más ingeniosos y se estudian medios en la forma lícitos, pero en el fondo anterióres á las propias leyes por sabias y previsoras que sean; y de no ser así ¿de qué sirven las leyes? Mejor seria no dictarlas, como decía Cicerón, que no observarlas ó cumplirlas mal.

(1) En la sesión celebrada en el Senado el 2l de Abril de 1894, el Sr. Romero Girón se lamentó de que el Poder central retuviera indebidamente los recargos de la contribución Territorial é industrial que corresponde á los Ayuntamientos, siendo á la vez inesorable para exigirlos el cumplimiento de sus obligaciones.

Los Sres. Cnesta, Santiago y Oliva, se quejaron en la misma sesión de la injusticia que se comete al negarse la Hacienda á devolver los pagos hechos por compras de bienes nacionales, cuando las ventas han sido anuladas por la misma Hacienda, y segun el señor Torre Villanueva adeudaba la Hacienda por tal concepto 50 millones que recibió y no ha devuelto.

En Marzo del propio año se publicaron anuncios en hojas impresas de gran tamaño para vender con una rebaja considerable los atrasos que adeuda el Estado por inquilinatos de la casa que mediante escritura píblica, tiene arrendada en Orense para sus oficinas. 
Verdadera clase para la mejor solución del tema.

Pero además del buen ejemplo la arriba para simplificar y moralizar la Administración y la Política, y para cumplir las leyes, es conveniente estimular el mérito, y corregir todas las trasgresiones que se cometan. Todo lo cual puede conseguirlo el Gobierno que se proponga de verdad llevarlo à cabo; aunque al pronto encuentre algunas dificultades inherentes á toda obra redentora, y en todos los Gobiernos reconocemos los más plausibles deseos para mejorar la Administración pública.

Un Gobernador civil como se proponga corregir los abusos é inmoralidades que se cometan en la provincia que le haya sido con. fiada, lo consigue; si desea que no existan casas de juego, esos antros del vicio, donde se sepultan fortunas, y hasta las vidas de algunos que à ellas concurren, puede lograrlo; si an hela que las Diputaciones provinciales cumplan fielmente sus deberes, conseguido lo tiene; de los Ayuntamientos es más facil alcanzarlo, pues estamos persuadidos que ningun Alcalde, absolutamente ninguno, faltaria 
á sus deberes si el Gobernador no lo consintiera. Pues si es indudable que esto pueden conseguirlo los Gobernadores, con mayor facilidad puede el Gobierno alcanzarlo de los mismos Gobernadores civiles, y demás Autoridades y funcionrios, por que ¿qué Gobernador de provincia ni qué Delegado de Hacienda, funcionario priblico ó empleado cometeria la menor trasgresión y se habia de oponer á la fiel observancia de las leyes, sabiendo que la separaración del cargo la publicaria inmediatamente la Gaceta, y que los Tribunales ordinarios se encargarian sin la menor dilación de depurar la infracción cometida, y de imponer el debido correctivo?

Creemos poder asegurar, sin temor de equivocarnos que ninguno.

Lo que hace falta es energia, fuerza de voluntad, para combatir sin tregua ni descanso la anemia moral que padece la nación, y que si la fisiológica debilita el organismo humano, debilita más à aquella el organismo administrativo.

Y lo que decimos de la Administración pública en la referente á la Península, puede muy bien hacerse extensivos á nuestras pasiones ultramarinas. ¡Quien sabe si muchos millares de honrados y laboriosos hijos del pueblo no hubieran tenido que ir á la manigua á sepultarse en aquel cementerio de españoles, si en Cuba se hubiese administrado 
siempre honradamente! ¡Y quién sabe si no se establece y consolida en aquella importante Colonia, hermosa perla de nuestras Antillas, una Administración pulcra é inteligente, y un sistema de gobierno ámplio y previsor, las consecuencias funestas que pueden sobrevenir!

Es, pues necesario, urgente, apremiante en extremo más que barrer estirpar de raiz, el cáncer de inmoralidad do quiera que se encuentre. El mal es crónico y de hondas raices, pero no incurable: y por lo mismoque es dificil de corregir, la curación será más meritoria.

Este debe ser en nuestro concepto, más que ningun otro, el gran toque de engrandecimiento.

Moralizar la Politica y la Administración, simplificar la organización administrativa, y cumplir las leyes.

No dar motivo ni siquiera pretexto para decir que en este desventurado pais se ha perdido toda noción de justicia, que las cataratas del inmenso Niágara de la inmoralidad hánse desbordado á torrentes, que hay bulas de Composición, que la política todo lo invade, quita y pone jueces y magistrados á su antojo; que se salvan los fuertes y se ahogan los débiles; ni á que se consideren como axiomas las metáforas el que no tiene tio, no pasa el rio, el que hace la ley, hace la trampa; los peces mayores se comen á los menores, etc., sinó que la 
justicia se aplique por igual á todos, sin distinción de clases. Que no haya quien autorice en las provincias ni en los municipios la más ligera trasgresión, para que los particulares tengan sólida y verdadera garantia contra toda clase de abusos y atropellos.

Cuando los gobernantes no consideren la política como mero arte de mecanismo constitucional, y atienda exclusivamente a los intereses generales de la pátria y del Estado.

Cuando las leyes se interpreten atendiendo únicamente la letra de las mismas à principio que las informa (que no debe ser otro que el de la razón y la justicia) y no segun mejor convenga ó lo exija el interés particular del personaje influyente, del amigo y correligionario, en perjuicio del débil y para hacer guerra implacable del enemigo, po. niendo en práctica la antigua frase romana: Adversus hostes, eterna autoritas esto.

Cuando la responsabilidad judicial llegue á ser un hecho, y tambien lo sean de verdad la administrativa y la gubernativa (que no lo son mas que en el nombre) para evitar sensibles errores con el carácter de notorias injusticias, y perjuicios enormes á los injustamente perseguidos.

Cuando los agricultores sean indemnizados á la mayor brevedad de las pérdidis que ocasionen en sus propiedades los difurentes 
fenómenos metereológicos, en vez de las dilaciones y entorpecimientos para conseguir únicamente el perdón de la contribución im. puesta á las fincas que han sufrido daños por consecuencia del granizo y las inundaciones, (cuyo remedio aunque pobre y mezquino tanto se le regatea) y nada por los que ocasionan las heladas y fuertes sequias; como igualmente á los ganaderos por las pérdidas que experimentan en sus ganados.

Cuando los particulares, para el desarrollo de sus iniciativas encuentren apoyo y protección por parte del Gobierno, en lugar de obstáculos y gravámenes.

Cuando no se diferencie la Administración de los administradores y la Justicia de los encargados de administrarla; el estandarte de la moralidad forme la divisa de nuestro escudo; la propiedad sea respetada; prevalezca la fuerza de la razón sobre la razón de la fuerza; el fiel cumplimiento de las leyes sea un hecho y haya cesado en España toda clase de arbitrariedades é injusticias ¡Oh! entónces, y sólo entónces renacerán la confianza y la tranquilidad perdidas que, si necesarias son à los habitantes de los grandes centros de la población, lo son muchos más á los que viven en las pequeñas localidades, sin medios de defensa y divididos por odios y antagonismos, para que puedan dedicarse con mayor gusto y esmero á sus tareas agrícolas. 
Entónces se abrirán nuevas vias para el transporte de los productos agricolas, evitando además la emigración de trabajadores á otros paises, en los que sufren tan tristes decepciones, enfermedades, y aún la muerte, en vez del codiciado oro que van buscando: se establecerán mejoras en los cultivos, ensancharán sus horizontes todas las fuentes de riqueza y florecerán la industria, el comercio y muy singularmente la agricultura y ganaderia.

Entónces ya no dirán cosas de España como con despreciativo énfasis y natural asombro exclaman los escritores y publicistas franceses é ingleses al ocuparse con más ó menos acierto de nuestras costumbres peculiares, de las incongruencias de nuestra complicada Administración, y del modo de entender y practicar la Política.

Cierto que no disfrutamos de una felicidad consumada, ni vivimos en el mejor de los mundos posibles, $\mathrm{y}$ aun cuando algunos extranjeros digan cosas de España, no tenemos, sin embargo, cuestiones tan graves como la del Panamá; (I) tampoco

(1) Verdad es que en Francia se castiga á los políticos negociantes altos y bajos como lo demostró la condena de Lessep, la de Reinach, exministro; la de Magnier, senador y otras. 
Panaminos (I); los conflictos que en Irlanda; las corruptelas que en Rusia (2) ni las convulsiones que tanto agitan algunos Estados americanos; la emigración noes tan creciente como en otros países europeos (3); ni el estado de nuestra Hacienda tan desastroso como el de

(1) Así llamaron algunos periódicos á los abusos atribuidos á los directores del Banco Romano, causando en Italia tal impresión la solnción recaida, que el ministro de Justicia ha tenido que dictar una medida a fin de averiguar lo que haya de cierto en las suposiciones que se hacen acerca de si los magistrados que juz. garon á los procesados instruyeron la causa cumpliendo rectainente con sus deberes, ó faltaron á este á săbiendas.

(2) Que han obligado al Czar á tomar participación directa en el nombramiento de empleados porque los destinos se vendian por dinero.

(3) Segun una estadística que tenemos á la vista;. durante el año de 1894 llegaron al puerto de Nueva York 357.857 europeos, que forman hoy parte de la población de los Estados-Unidos.

El mayor contingente de esta emigración lo dió Italia, el segundo Austria-Hungría, el cuarto lnglaterra, después Rusia y Francia, siendo nuestra nación el país europeo á quien menos debe la despoblación de Europa, pues no han ido á Nueva York más que 79 españoles.

Debido al malestar económico que se experimenta en Italia es también el pais que dá mayor contingente al Brasil, República Argentina, Chile y Méjico. 
otras potencias (1); pero esto no debe ser obstáculo para que procuramos corregir los males que lamentamos en nuestro pais $y$ quemar el rastrojo de la mies antigua para

(1) Ur. Ottomar Hasipt en su obra sobre los arbitrajes inserta el siguiente cuadro de las deudas y habitantes de los Estados europeos en 1892 en esta forma:

\begin{tabular}{|c|c|c|}
\hline PAISES & HABITANTES & DEUDA EN FRANCOS. \\
\hline Prancia. & $38.3+3.192$ & 30.611 .685 .000 \\
\hline Alemania.. & 49.428 .470 & 13.498 .804 .000 \\
\hline Inglaterra. & 37.879 .285 & 16.941 .989 .000 \\
\hline Austria-Hungria. & 41.384 .638 & 15.413 .181 .000 \\
\hline Bẻlgíca. . & 6.136 .444 & 2.314 .854 .000 \\
\hline Bulgaria. : & 3.154 .375 & 230.892 .000 \\
\hline Dinamarca. & 2.172 .380 & 259.389 .000 \\
\hline España. & 17.560 .352 & 6.207 .027 .1000 \\
\hline Grecia.. & 2.217 .000 & $75(1.329 .000$ \\
\hline Holanda. & 4.511 .415 & 2375.975 .000 \\
\hline Italia. . & $30.3+7.291$ & 12.449 .985 .000 \\
\hline Luxemburgo. & 211.088 & 16.170 .000 \\
\hline Portugal. . & 4.708 .178 & 3.269 .808 .000 \\
\hline Rumania. . & 5.038 .342 & 1.032 .824 .000 \\
\hline Rusia.. & 93.651 .771 & 17.324 .120 .000 \\
\hline Servia.. & 2.161 .961 & 328.739 .000 \\
\hline Suecia.. & 4.784 .981 & 358.719 .000 \\
\hline Noruega. & 1.988 .664 & 161.327 .000 \\
\hline Suiza. . & 2.917 .76 & 53.402 .000 \\
\hline Turquia. & 8.049 .540 & 2.611 .467 .000 \\
\hline Finlandia.. & 2.380 .100 & 77.736 .000 \\
\hline Montenegro.. & 200.054 & 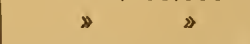 \\
\hline Totales.. & 359.227 .287 & 126.288 .422 .000 \\
\hline
\end{tabular}


sembrar la nueva semilla de la que han de nacer grandes plantas, cuidando de cultivarlas con el buen ejemplo, para que la cizaña no se apodere del campo é impida á los sem. brados su fructificación y lozania, no olvidando que destruir se consigué en poco tiempo, pero para edificar la conciencia pública se necesitan muchos años de lenta y obstinada labor, en cuya árdua empresa, la más espinosa y la más dificil de corregir, no habrá de desmayar ningun Gobierno, aunque no logre el fruto de sus afanes y trabajos más que muy paulatinamente y a costa de sacrificios, pues. sabido es que no hay atajo sin trabajo, y porque si como ha dicho Montesquien:-las naciones tienen siempre los Gobiernos que se merecen, el de este pueblo tan admirado como temido debe aspirar á ser grande, pues grande es España por su historia y por sus. mismas fuerzas, aunque no se le cuente hoy entre las grandes potencias. Los puestos deben conquistarse sin esperar á que se adjudiquen.

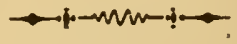




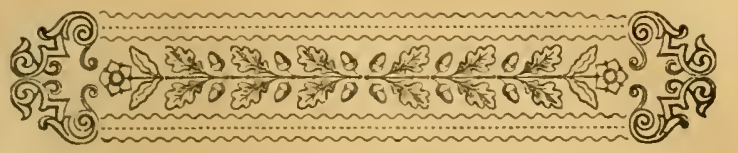

\section{CAPITULO IV.}

La enseñanza agricola.

1. Ventajas de la ciencia.-A ella principalmente debemos los inventos y las comodidades que hoy disfrutamos.

2. La ley de enseñanza agricola.-Debe exigirse el cumplimiento de la misma.-Las conferencias dominicales. - La propaganda agricola.

3. La enseñanza primaria.-Debe hacerse obligatoria.-Medida sencilla que pudiera dar favorables resultados.

4. Error funestísimo de muchos labradores.-La vida en el campo.-Acción que conviene ejercite el Estado.

Producir bueno y barato, y en relación à las necesidades del consumo no es un ideal; tampoco una utopia, ni ilusión quimérica, $y$ menos un milagro, sino que puede y debe llegar à ser un hecho, una realidad palmaria y evidente. 


\section{Ventajas de la ciencia.}

Para conseguirlo el agente propulsor por excelencia es la instrucción agrícola.

La buena instrucción es el primero y más alto principio de la prosperidad de los pueblos; es la columna finisima en que deben apoyarse todos los que aspiren á perfeccionarse por el progreso, la moralidad y el trabajo, que vienen á constituir la trilogia misteriosa de las sociedades modernas; y siendo hoy la primera necesidad agraria del pais la instrucción agrícola, todo cuanto tienda á difundir el principio de la ciencia agronómica, será altamente laudable y en extremo provechoso; pues la agricultura más que trivial y sencilla, es de las artes y ciencias más importantes y difíciles que se hallan bajo el dominio del hombre.

Si la instrucción y la difusión de la ciencia son más que convenientes necesarias en otros paises, lo son mucho más en el nuestro, en el cual la cifra de las personas que carecen absolutamente de todo principio literario está en una proporción desconsoladora: pues 17.555 .632 habitantes existentes en España en 1889, según datos del Instituto Geográfico y Estadístico, sólo 5.004.470 sabian leer y escribir.

Reuniendo nuestro suelo como reune los más fertilizantes medios de producción, 
situado en las mejores latitudes del globo, con variedad de climas favorables á toda clase de cultivos que nos permite producir los frutos más ricos y de mejor calidad conocidos, es indudable que si no obtenemos mayores resultados de la tierra, no es por las condiciones del terreno, sino por nuestra apatia y falta de conocimientos.

Debido á la instrucción agricola, Francia ha elevado, en pocos años la producción media de cereales en más de un 50 por 100 , lo propio que Bélgica y Rusia, en cuyos paises, y en una misma superficie de terreno laborable, aunque no tan fertil, ni tan propios sus condiciones climatológicas se cosecha sin embargo mayor cantidad que en España, y no creemos sea aventurado asegurar que el mismo favorable éxito pudieramos obtener en nuestra nación por idénticos procedimientos, los cuales consisten sólo en la reforma de los aperos y aparatos de labranza, labores, abonos y semillas apropiadas á cada terreno, con la ciscunstancia ventajosa de poder practicar en nuestro pais el cultivo extensivo, en vez intensivo á que se ven obligados á adoptar en Inglaterra, Bélgica, Francia, Italia y Alemania.

Es un hecho admitido por la ciencia agronómica y corroborado por la experiencia que el escaso rendimiento de las cosechas obedece más que al mal tiempo á la insuficiencia de 
labores ó á que estas no se practican en tiempo y sazón; á la escasez de los abonos, ó à su mala condición, como también á la mala calidad de las semillas, ó áque no han sido destinadas en los terrenos más convenientes; todo lo que es necesario practicar con el conocimiento debido, y aun cuando los gastos de cultivo sean mayores, estos resultan después remunerados con creces por el aumento de productos.

«Es tanta la eticacia de la enseñanza agrícola, cuanto que ella enriquece à los indigentes y arraiga á los ignorantes»; asi exclamaba el esclarecido filósofo ateniense Jenofonte, discipulo de Sócrates; y de la misma autorizado opinión fué Pronápides el inventor de la escritura occidental y maestro del insigne Homero.

Es necesario respetar la ciencia y acoger con paternal solicitud y confianza las ideas, auxilios y buenos propósitos de los hombres del saber; no para dejarse llevar exclusivamente de aquellas, sino para comprobarlas en el crisol de la práctica, por medio de ensayos en pequeña escala, de los cuales se puede desistir cuando mejor plazca, ya den ó no favorable resultado, y sin desatender por eso, si no se quiere, la rancia práctica, ni la mal entendida rutina.

En la ciencia es donde deben buscar los agricultores un auxilio eficáz para el buen 
éxito de sus empresas y al propio tiempo honrarla y protegerla en unión del Gobierno, siguiendo el ejemplo de las naciones cultas y civilizadas como Inglaterra al sentarse el Presidente de la representación nacional sobre un saco de lana en memoria de lo que valió el comercio de esta mercancia, y Holanda al elevar una estátua al inventor de la preparación de los arenques.

\section{A la ciencia debemos los}

inventos y las comodidades que disfrutamos.

¡Cuánto y cuànto debemos à los hombres de verdadera ciencia! ¡Cuántas maravillas tenemos que admirar, y que ya muchas superan á cuànto pueden exigir las necesidades de la vida, con las que no hubieran soñado nuestros antepasados, y á las que no habriamos llegado sin el talento, asiduidad, perseverancia y sinsabores de los grandes génios! ¡Y cuán poco nos acordamos de los esfuerzos y de los sacrificios á cuya virtud, laboriosidad, sufrimientos y aun martirios debemos el regalo, comodidad y bienestar que hoy disfrutamos!

Para reconocerlo no es preciso recordar los rudos y penosos trabajos de Hiparco, Tolomeo y Copénico para determinar el verdadero sistema planetario; de Benal para la invención del cristal; Speria en la de los 
anteojos; Mencio del telescopio; Játiva del papel; à Gioja que dió á conocer la brújula en Europa (I): à Schawast, según el testimonio de valiosos autores y Bacón segun otros, por su famoso invento de la pólvora; ni à las dos grandes figuras que descuellan entre las demàs del siglo XV Gutemberg y Colón, el primero por su prodigiosa invención de la imprenta, que tanto influyó en todos los ramos del saber humano, y el último por el descubrimiento del nuevo mundo, suceso el más importante y trascendental que regis. tran los anales de nuestra historia; á Ponce de León que en el siglo XVI inventa el modo de instruir á los sordo-mudos; Galileo que en el siguiente inventa el péndulo y descubre el movimiento de la tierra; Torricelli el termómetro; Newtón la ley de la gravitación universal; Franklin en el XVIII que con su maravilloso pararrayos libra al hombre de los funestisimos efectos del fluido eléctrico en el momento de terrible tempestad. El siglo actual; apellidado con tanta razón el de las luces, cuenta con hombres de gran ingénio y valía como Morse, autor del primer telégrafo electro magnético que facilita la comunicación con una rapidez asombrosa de uno á otro continente; Stephensón que creó los

(1) Si bien ya fué conocida antes por los chinos, de quienes la tomaron los árabes. 
caminos de hierro, acortó las distancias y operó una gran revolución ea todos los ramos de la actividad humana; Frinyi inventor de las cerillas que tan buenos servicios prestan á todas las clase sociales; Bell con su teléfono que nos hace oir conciertos sororos y la pro-. pia $\nabla 0 z$ de los parientes y amigos separados. por largas distancias; Heilmann que ha resuelto el problema de la aplicación práctica de la electricidad á los caminos de hierro con su locomotora eléctrica, la que puede desarrollar una velocidad máxima de 200 kilómetros por hora (r); Gray y Bertillón con su telautógrafo que transmite los dibujos ó retratos á medida que el expedidor los escribe, en un papel especial: Edissón hombre sin semejante hasta el día, el más original y el más fecundo de cuantos inventores han conocido las edades, con más de quinientas patentes de otros tantos inventos, siendo el más impor-. tante y prodigioso el fonógrafo que retiene y conserva incólume la voz humana y todos los demás sonidos para reproducirlos con la mayor fidelidad cuando el hombre lo desee(2),

(1) Experimentada oficialmente en Mayo de 1894 entre París y Nantes, con gran éxito.

(2) Y que un relojero de Ginebra le aplica en la actualidad á uno de sus relojes, el cual en vez de dar á conocer las horas por medio de lentas campanadas, las pronuncia. 
con su complemento el kinestóscopo (I) fundado en la duración de la retina para dar vida y movimiento á las figuras tomadas instantáneamente de la realidad.

Y ¿quién sabe, si como opina Berthelot, así la física y la química llegarản á reemplazar al combustible?

Quién sabe si la ciencia hallará también medios para dirigir con rumbo cierto y seguro globos y aparatos voladores que surquen la regiones aéreas! ¡Quién sabe si podrá establecer y realizar la ubicuidad en cuanto humanamente sea posible, con vertiginosa rapidez del pensamiento! y ¡Quién sabe por último, las sorpresas que á las generaciones futuras, y algunas quizá á la actual reserva la ciencia!

Sin los hombres de verdadera ciencia, los productos agricolas no podrian ser transportados á paises lejanos, ni aún á muchos de los inmediatos.

Hoy que debido á los auxilios de la ciencia tenemos cómodas carreteras con sólidos puentes que facilitan el tránsito de los más

(1) Perfeccionado por el sabio Lumiere, y por medio de su ingenioso aparato titulado cinemotógrafo no ya uno sólo, sino miles de expectadores á la vez, pueden contemplar en su tamaño natural las personas, animales, edificios y cuantos objetos deseen ver reproducidos. 
anchurosos y caudalosos ríos; canales de navegación para el transporte de los frutos del campo, y de riego para fertilizar los campos, abrasados por las prolongadas sequias; que vemos perforadas la antes inaccesibles montañas; para transportar con toda comodidad viajeros, correspondencia pública y todos los productos de la tierra, la locomotora atravesando rápidamente valles, ríos y montañas; y con igual objeto el vapor surcando los dilatados y peligrosos mares.

Empresas que a las generaciones pasadas hubieran parecido un imposible, ó una gran locura se llevan á cabo con el mayor éxito, como las colosales y atrevidas del puente sobre el canal de la mancha, y la de un ferrocarril tubular submarino á través del mismo canal; el pensamiento de unir el Atlántico y el Mediterráneo á través de Francia, vá ganando terreno cada dia, y la terminación del canal de Panamá (no obstante las graves dificultades surgidas de órden diverso al cientifico) se espera que pronto sea un hecho como lo fué la del istmo de Suez, y como lo ha sido la del canal de Kiel, obra también colosal y atrevida que une el mar del Norte al Báltico ( 1 ).

(1) Cuya inauguración se verificó ‘on gran pompa y solemnidad en 21 de Junio de 1895. 
Hoy que por los interesantes estudios y trabajos de Liebig, la fabricación y empleo de los abonos industriales ó artificiales bien combinados en principios nitrogenados, potásicos y fosforados para devolver à la tierra las substancias fertilizantes que las plantas extraen de ella, es otra de las conquistas de la ciencia moderna; cuya idea ha sido después comprobada por medio de los análisis y experimentos efectuados por químicos de la Sociedad Real de Agricultura de Inglaterra, habiendo evidenciado el grado de utilidad y eficacia de los mismos con el más favorable éxito.

Hoy que para las prácticas agrícolas las casas constructoras de Horward, Tasker, Sturgess, y Foley y otras muchas ponen á dispocición de los labradores arados perfeccionados; máquinas sembradoras que al mismo tiempo labran la tierra y cubren las semillas; segadoras, trilladorasy aventadoras movidas à vapor por fuerza animal, cuyos satisfactorios resultados llenan los más exigentes deseos.

Hoy que el vapor y la electricidad se aplican también á la agricultura; que muchas teorias de carácter científico han pasado del periodo esperimental y de información, constituyendo hechos incontrovertibles; hoy que la ciencia descifra los fenómenos de los cuerpos celestes; analiza la composición física $y$. 
quimica de las cosas creadas, y facilita enérgicos recursos terapéuticos para aliviar muchas dolencias, contribuyendo asi al bienestar del género humano; hoy en medio de tantos y tan notables progresos; en medio de tantas y tan importantes conquistas alcanzadas por la ciencia moderna; en vez de desdeñarla, rindámosla homenaje de admiración, respeto y simpatia, y digamos con Byron: ¡más luz! y más protección á esa ciencia bienhechora que no cesa en sus estudios é investigaciones hasta agotar los recursos de su saber y de su ingénio en holocausto del bien público.

Los hombres de verdadera ciencia no proceden jamás por miras á intereses bastardos, pues éstas no tienen cabida en almas nobles y elevadas; y las ventajas debidas à sus desvelos, estudios y sacrificios, las disfrutan todos aquellos que estiman los consejos de la ciencia y saben utilizar sus conocimientos y adelantos; de la propia manera que cuando una fórmula bien dispuesta y preparada devuelve la salud al enfermo no son el médico y el farmacéutico quienes utilizan principalmente de tal beneficio, sino el enfermo mismo, que guiado por los consejos de la ciencia, aplica con oportunidad aquélla.

No es tampoco que los medios que propongan pertenezcan al mundo de la mitologia, consistan en arte de magia, nigromancia, 
artificio, ni sean en extremo costosos y de difícil realizacion, $y$ menos como el mentir de las estrellas, puesto que los relativos á las prácticas agricolas pueden comprobarlos hasta las clases poco acomodadas, como aconseja el ilustrado agrónomo francés Monseur Georges Ville por medio de repetidos ensayos en muy pequeña escala, y con el conocimiento debido, hasta depurar sus más insignificantes detalles.

Los terrenos de todas zonas y paises, ya estériles ó feraces, suelen ser siempre susceptibles de mejoras para obtener de ellas mayores y más positivos rendimientos.

Cierto que no basta solamente estudiar en los libros, porque muchos conocimientos agricolas se adquieren mejor con la práctica. El agricultor necesita instrucción teórica y práctica, basadas en el resultado especial de la agricultura de su , región, pues cada zona tiene condiciones y necesidades peculiares; por lo mismo es necesario asociar la una á la otra, para que ambas marchen siempre unisonas como buenas hermanas al estudio, ensayo y observación; saber practicar las teorias y comprender la teoria de las prácticas, para obrar con acierto y obtener mayores productos de la tierra, y porque además, una de las aspiraciones legitimas del hombre es la de aspirar á ensanchar cada día su órbita de acción, su actividad é inteligencia. 
La ley de la enseñanza agrícola.-Debe exigirse el cumplimiento de la misma.-Las conferencias dominicales.

La ley de $1 .^{\circ}$ de Agosto de 1876 , sobre enseñanza agrícola, concedió derecho á todas las provincias para establecer granjas-modelos, experimentales y estaciones agronómicas; dispuso que todos los domingos hubiera una conferencia agrícola en cada capital sobre los temas que fijasen préviamente las Juntas provinciales de agricultura; y que en los mismos dias se explicara en todos los pueblos de la Monarquía por las personas que se prestasen a hacerla una cuestión referente á la industria que mas interese á la localidad, y que á falta de otras personas, el maestro de primera enseñanza leyese un capitulo de la obra que le designase la Junta de Agricultura; con otros sábios preceptos que por lo mismo que son del mayor interés para el fomento de la agricultura, han caido en desuso y se hallan relegados al olvido.

El Rey D. Alfonso XII, protector entusiasta de los intereses rurales, esperaba mucho de las Conferencias, y en la Sesión inaugural celebrada en el suntuoso paraninfo de la Universidad Central el 3 de Diciembre de I876, excitaba à difundir la luz de la ciencia con estas augustas y elocuentes palabras: 
"En efecto, como ha dicho el Sr. Secreta"rio de la Junta, y en particular el Sr. Mimnistro de Fomento, Las Conferencias agricolas, pueden ejercer tan benéfica influencia »en la prosperidad del pais, como que en wellas se han de tratar todas las cuestiones )de que depende el porvenir de la Agricul"tura. La repoblación de nuestros bosques; wel estudio de riegos y aprovechamiento de maguas de nuestros ríos; el de las diversas mzonas agrícolas de la Peninsula y del cultivo "más propio á cada una de ellas; y, en fin, nla solución de todos aquellos problemas que, mbien estudiados y resueltos, deben ser fuenwte de prosperidad y de riqueza, han de watraer á este centro á los hombres estudionsos que puedan contribuir á su buen éxito ucon las ideas de la ciencia ó con las observa"ciones de la práctica».

Es necesario, pues el cumplimiento de una ley tan provechosa y que tanto bien puede reportar en favor de los intereses agricolas.

El articulo 9. ${ }^{\circ}$ sobre Las Conferencias dominicales, debe cumplirse particularmente en los pueblos; si bien estimamos que debe modificarse para reducir aquéllas á un sólo domingo en cada mes, y exceptuar los relativos á la recolección de frutos, como medio de que resulten más útiles y provechosas; porque asi como la prohibición excita más 
el deseo, la obligación ineludible cuando es constante, pesada y monótona se hace desagradable y en ocasiones resulta ineficaz; debiendo las Juntas provinciales exigir de los Alcaldes en los tres primeros dias de cada mes la remisión de un estado en el que se consignen los nombres de las personas que hayan tomado participación en las conferencias agrícolas del mes anterior, el tema ó temas sobre que haya versado, reformas propuestas para la mejora de cultivos, fruto obtenido de aquella y cuantas observaciones fueren conducentes al importante fin de fomentar la riqueza agricola y pecuaria.

Las mismas Juntas provinciales, deberán también estimular con el ejemplo é inspeccionar cuanto sea posible para que se cumpla el artículo referido.

Dos veces al año publicarán en el Boletin Oficial, una relación de las personas que por su celo é interés en pró de la enseñanza agricola, más se hayan distinguido en cada respectivo semestre. Al terminar el año, formarán la oportuna propuesta de recompensas, por méritos especiales adquiridos en las conferencias. agricolas, la que serà publicada en los Boletines Oficiales y periódicos locales, para quedurante los quince dias siguientes, puedan interponerse cuantas reclamaciones fueren procedentes; y rectificada la elevarán sin dilación al Ministerio de Fómento. 
La propaganda agrícola.

Por Real orden de 15 de Enero de 1895 se declaró en suspenso la publicación de la Gacela Agricola, por haber terminado el contrato celebrado para la impresión y publicación de la citada revista que por espacio de i 8 años consecutivos se habia venido sirviendo á los Ayuntamientos.

La experiencia ha demostrado que la expresada revista aunque interesante y redactada por personas de una ilustración muy vasta y de conocimientos agrícolas poco comunes particularmente teóricos, no ha llenado los deseos de los agricultores, pues muchos de los ejemplares se hallan en algunos archivos municipales en el mismo estado que se recibieron. Por lo tanto, conviene dar otra forma á la susodicha publicación, adoptándola á los conocimientos y deseos de quienes hayan de pagarla y obtener fruto de su lectura; y á tal fin conceptuamos lo más conveniente que el Estado realice con decidido pro. pósito la campaña de la publicidad, gratuita á ser posible, ó en otro caso por una cuota muy reducida, por medio de periódicos diarios (en vez de una rejista quincenal y de I 32 pảginas como lo era la mencionada Gace$t a)$ en los que de un modo claro $y$ concreto se explique à los labradores la manera de preparar y emplear los abonos y las semillas más 
convenientes á cada terreno; de practicar riegos y labores; los articulos que tengan mayor consumo y aceptación; sus precios en los principales mercados nacionales y extranjeros, y cuantas reformas sean convenientes para el desarrollo y fomento de la agricultura, con el objeto de difundir la enseñanza y los conocimientos teórico-prácticos en un ramo tan vasto é importante, y entre una clase tan numerosa en España como la de agricultores, á fin de llevar hasta la última aldea las nuevas ideas de carácter cientifico que ofrezcan los adelantos modernos, para que el retraso no sea el estado normal del labriego.

De no realizarse gratuitamente la propaganda agrícola, deberá guardarse siquiera la misma previsora excepción establecida por la expresada ley de $10^{\circ}$ de Agosto de 1876 en favor de los 1500 Ayuntamientos de menor vecindario, en los cuales es más precisa la lectura diaria y provechosa, por lo mismo que en ellos se carece de los valiosos elementos de instrucción de que disfrutan otras poblaciones de màs importancia.

También será conveniente que el Ministerio de Fomento forme y publique, en vista del censo de población, la lista de los pueblos que en su caso hayan de ser exceptuados del pago, pues algunos de los que lo fueron para la Gaceta Agricola se vieron no obstante 
apremiados por el importante de la suscripción y á los demás no se les sirvió tan interesante revista, lo cual no dejó de ser una complacencia en favor de una empresa, pero en perjuicio de muchos pueblos interesados (I).

La enseñanza primaria.-Debe hacerse oblitoria.-Una medida sencilla que pudiera dar resultudos.

Pero es necesario empezar por la base, por la piedra angular del edificio de la educación, por la enseñanza primaria, la más. útil á la vida de los pueblos; pues en otro caso de nada serviria la propaganda de las. ideas en un país como el nuestro en que la mayor parte de los habitantes no saben leer ni escribir.

(1) En los números $3 .^{\circ}$ y $4 .^{\circ}$ de la Gaceta Agrícolo correspondiente á los días 15 y 30 de Noviembre de1876, se publicó la relación de los 1.500 A suntamientos de menor vecindario exceptuados del pago de la suscripción; pero como desde el referido año al de la fecha se han publicado dos nuevos censos de población, muchos pueblos han variado seguramente el número de habitantes de alta ó baja, y por lo tanto, procede que se fije, determine y publique en su día una nueva lista ó relación para que disfruten de tal beneficio los pueblos á quienes corresponda según el censo oficial vigente, para lo relativo á las pablicaciones sucesivas que deberán ser remitidas también á los Ayuntamientos exceptuados del pago. 
La enseñanza primaria debe ser obligatoria, gratuita y función del Estado, porque la instrucción es la base única y absoluta del bienestar de las naciones; el destello purísimo que ilumina las inteligencias y disipa las tinieblas con su foco perenne de luz explendorosa.

Instruir, es construir (1).

El destino de los pueblos depende de la educación de la juventud (2).

La instrucción alimenta el espíritu, y la educación nutre el alma (3).

Educar instruyendo debe ser el problema de la humanidad, porque además de ser ineludible la ley del progreso (4) la educación es una segunda existencia dada al hombre, y en la buenă educación imperan también las buenas costumbres (5); pues hasta la práctica de la virtud parece que repugna cuando va acompañada de malos modales (6).

Adolescens juxta viam suam, etiam cum senuerit, non recedet $a b$ ea (7).

(1) Victor Hugo.

(2) Demócrito.

(3) Cormen.

(4) Ponce de León.

(5) Aristóleles.

(6) Midletón.

(7) Pio IX, 29 Jun. 1872 á los Rectores de los Colegios. 
Es de urgente necesidad hacer obligatoria la asistencia á las escuelas de primera enseñanza, de todos los niños comprendidos en la edad de 6 á ro años inclusive, exigiendo multas á los Ayuntamientos respectivos, sin perjuicio de que éstos se reintegren delos padres, cuyos niños hayan cometido las faltas de asistencia, y de cumplir lo dispuesto en el art. 603 del Código penal (1).

Por lo mismo que estimamos muy en alto grado á las Corporaciones municipales, á esa institución tan importante y que anterior al Estado es la base de la Administración general, no vacilamos proponer en primer término para la misma, la responsabilidad insinuada, en la que podrán escudarse los Ayuntamientos para evitar muchos inconvenientes que, bien á pesar suyo, toleran en la actualidad por consideraciones de amistad, parentesco, etc.; y ya que muchos tengan por axioma que la vida de los pueblos envejece, empobrece y envilece, no debe omitirse medio alguno para fomentar en los mismos la enseñanza primaria, base de todo

(1) Art. 603. Serán castigados con la pena de cinco á quince dias de arresto y reprensión:

5. Los padres de familia que abandonaren sus hijos, no procurándoles la educación que requiera su clase y sus facultades permitan. 
adelanto y progreso, la cual puede evitar y remediar muchos males. Por otra parte, los Ayuntamientos dentro del círculo de sus atribuciones, en las ordenanzas municipales y por los demás medios á que les autorizan los artículos 72, 73, 74 y 77 de la ley Municipal, pueden hacer mucho para obligar à los padres á que en vez de dejar sus hijos entregados á la vagancia y à la corrupción, los envien á la escuela á recibir la mejor herencia que pueden legarles, que consiste en una buena instrucción y educación; con las que además la ignorancia desaparecerá paulatinamente, evitando asi muchos de los males que la sociedad lamenta (I).

Error funestísimo de muchos labradores.

Además de la falta de ilustración agricola, existe otro mal, un error crasisimo en muchos labradores; $y$ es la poca inclinación que tienen y el poco interés que demuestran por la agricultura.

La clase agrícola es á no dudarlo la más sóbria, la más laboriosa y la más sufrida; pero sucede lo que en las demás clases sociales, que hay también sus excepciones, y algunos labradores que aunque pobres no

(1) En la Parte 4.a precisamos los medios para realizar las multas por las faltas insinuadas. 
quieren parecer que lo son, y dejándose llevar de una consideración superficial de las cosas, acuden al préstamo, é hipotecan sus fincas para apartar á sus hijos de las labores agricolas, con lo cual no se consiguen más que lastimosas realidades mal encubiertas por el falso brillo de la apariencia, en perjuicio de sus propios intereses.

En Italia, Inglaterra, Bélgica, en los Estados-Unidos y en otras naciones más adelantadas que la nuestra, los propietarios estudian agricultura y dedican sus hijos á esta ciencia tan amena é interesante, á esta noble labor de cultivar los campos, á la que Cicerón consideraba como la más adecuada, la más fecunda y la más digna ocupación del hombre libre é ilustrado; en la que obtienen crecidos rendimientos; mientras que en España el que puede vivir, aunque sea con estrechez, con las rentas que le producen sus tierras, se rebaja con ser hombre de campo, tiene á mengua ser labrador, entrega sus fincas á colonos pobres que carecen de instrucción y de los medios necesarios para mejorar las fincas y hacerlas producir, por cuyos medios es imposible que la agricultura adelante, las tierras rindan los productos de que son susceptibles, ni que propietarios y colonos prosperen lo que debieran. 
La vida en el Campo.

Olvidando que la vida en el campo es la más sana (como saben por si mismos), los que tienen medios educan à sus hijos para abogados, médicos, farmacéuticos, filósofos, militares, etc., sin consultar el atractivo ni la capacidad, difíciles de conocer en los primeros años cuando del estudio para la mejora de sus fincas rústicas, de la ganadería, de la explotación de minas y de cualquier industria fabril heredada ó adquirida, puede obtenerse un porvenir más halagüeño y seguro que de las carreras científicas ó literarias.

La agricultura ofrece ancho campo para que los hijos de las personas de posición, en particular los de los labradores, desarrollen su actividad y su inteligencia, conviertan éstas en dineros, sean útiles para la producción agraria y labren á la par que la tierra, la felicidad del hogar doméstico.

El trabajo dignifica; es ley universal y necesaria de la vida hamana. Los que se afanan en buscar el talismán de la felicidad que les permita vivir sin trabajar, olvidan sin duda el Código escrito por la mano de Dios; que no pueden eludir el cumplimiento de tan sagrado precepto; y que solamente en el trabajo honrado es donde se encuentra el progreso intelectual y material. 
La virtud-ha escrito $M$. Le Play-hace heróicos á los pueblos: el vicio acaba con ellos y los arruina.

El trabajo es la fuente de las virtudes; *por consiguiente, la institución que dé á conocer á todos, á pobres y ricos, de una manera activa la idea del trabajo humano, es la ínica poderosa à hallar soluciòn à este difícil problema (I)».

Por utra parte, la vida en el campo, además de ser la más sana porque es donde se respira el aire más puro y oxigenado, es asimismo la más tranquila y placentera (2) particularmente en el mes de las flores, como se apellida al mes de mayo, ostentando sus ricas y hermosas galas con su inmensa variedad de flores naturales: formando un conjunto precioso, un magnífico panorama que

(1) Ilartinez y González en su obra La Crisis de la Agricullura.

(2) Buen ejemplo tenemos en el diplomático de Versalles, en el hombre extraordinario que con su talento y su génio ha cambiado la gerigrafia y el estado nacional de una parte importante de Europa; sn Bismarck que ahora busca el gran secreto de la paz y tranquilidad, haciendo vida de campesino en su granja de Friedrichsruhe.

En análoga vida pacífica y campestre, blandiendo el hacha de leñador, le secunda el eminente estadista inglés Giadstone. 
tanto embellece los campos y embalsama el ambiente con sus suaves y deliciosos aromas.

En la primavera, estación feliz, en que las plantas verdean y florecen, $\boldsymbol{J}$ las semillas germinan, es cuando el labrador concibe la más grata de las esperanzas, al ver que todos sus afanes y trabajos van á ser en breve remunerados.

En el campo, bajo las caricias del sol que nace para todos los hombres, se contempla mejor el ancho firmamento, á la vista de tan maravilloso espectáculo, y desde donde mejor se puede elevar el pensamiento á los espacios, sentir algo y admirar mucho, ya que no comprender tanto portento.

El sudor que el hombre de su frente derrama, le recuerda su pequeñez, y la naturaleza, metamorfoseada por el cultivo y por el curso admirable de las estaciones, le revela á la vez que la mano del Omnipotente el consolador secreto del espiritu: la inmortalidad. Es tambien donde mejor puede inculcarse á los jóvenes el bello pensamiento del profeta. Initium sapientice timor Đomini, (I) base de la enseñanza cristiana, porque donde ésta falta, no se teme á Dios, y donde no se teme á Dios, no puede haber verdadera fraternidad, amor al prójimo, ni cosa buena.

(1) Eicl. I. 16. 
“Deber sagrado y premiantes es en todos los padres de familia y encargados de la enseñanza el procurar que la juventud se instruya en la religión y en las buenas costumbres, como conviene á personas cristianas, de lo cual depende en gran manera el bien priblico (I).

Además, la educación física es necesaria para desenvolver los órganos y las fuerzas del cuerpo, preservarle de todo cuanto pueda serle nocivo y restablecer la salud, cuando por cualquier circunstancia se hubiere alterado, que tanto aconseja la ciencia moderna, conforme con la tan célebre como repetida frase de Juvenal; Mens sana in corpore sano; pues ya nadie duda que el buen desarrollo físico puede conducir al desarrollo intelectual y por consiguiente al mayor grado de cultura; ó lo que es lo mismo; atender al desarrollo del cuerpo para llegar al perfecto desenvolvimiento de las facultades de la inteligencia; con todo lo que, los padres de familia harán cuanto esté de su parte á fin de conseguir que sus hijos sean útiles á Dios, á sus mismos padres, á la pátria y á la sociedad.

(1) León XIII, en su Encíclica Inmortálite Dei 1. Noviembre de 1885. 
Acción que conviene ejercite el estado.

Al Estado pues, corresponde cohibir de un modo más ó menos directo ese afản inusitado, ese error tan funestísimo de muchos padres de familia, (más extraño y censurable en los labradores) de apartar á sus hijos de la vida del campo para llevarles á sitios en que por cultivar su inteligencia, labran muchas reces su perdición y su ruina. Para el logro del objeto indicado entendemos que por ahora, será suficiente elevar los derechos de las matrículas de asignaturas, y los de los titulos académicos y profesionales (1); cuya medida y cualquier otra conducente al propio fin, además de allegar recursos al Erario, contribuirá al fomento de la riqueza agrícola, al mejor cultivo de los campos, y á labrar la felicidad del país, hoy más sediento y necesitado de verdaderos trabajadores, que de titulos académicos.

(1) Así lo proponemos en el capitulo de ruevos Ingresos. 



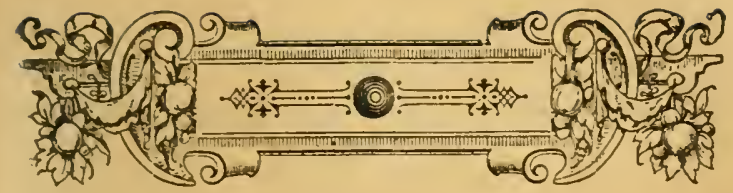

\section{CAPITULO V.}

Los Tratados de comercio y los Cambios.

1. La cuestión arancelaria es un factor esencial para la mejor solución del interesante problema agricola.

2. La protección racional es un medio necesario y eficaz para el fomento de los intereses nacionales.-Es además conveniente para harmonizar el capital y el trabajo.

3. Los cambios sobre el extranjero.-El régimen arancelario es el mejor correctivo del cambio internacional.

Los Tratados de comercio influyen poderosamente y de una manera tangible, directa, é inmediata en el régimen de los Estados y en favor ó detrimento de la producción, industria, comercio y del trabajo nacional; segun que aquellos sean beneficiosos ó perjudiciales á tan importantes elementos de riqueza.

Son, en verdad, indispensables por los grandes rendimientos que proporcionan al 
Tesoro (I) en alivio del contribuyente, y por lo mucho que pueden favorecer los intereses nacionales con los beneficios reciprocos que otorgen las partes contratantes. Sirven además para estrechar los lazos de simpatia, que unen á los paises convenidos, cuando responden á sentimientos mútuos y al verdadero interés de ambos.

Los pueblos como los indivíduos se deben reciproco afecto, no pueden ni deben vivir

(1) El impuesto de Aduanas fué conocido en todos. los pueblos de la Antigüedad donde tuvo alguna extensión el comercio, siendo hoy uno de los más esenciales, y el menos combatido de todos.

Los griegos y los romanos organizaron un sistema de aduanas sobre toda clase de mercaderías y además cobraban derechos de exportación y del tránsito.

Los países más libres y más florecientes utilizan la renta de aduanas, una de las más cuantiosas é importantes para acrecentar los ingresos de su Erario respectivo.

Inglaterra en el siglo XVIII estableció un sistema protector; y a mediados del actual llegó á recaudar anualmente en las aduanas más de 600 millones de pesetas.

Alemania, Francia, Italia y Rusia obtienen cuantiosas sumas del impuesto aduanero y los Estados. Unidos recaudan más del 50 por 100 de su presupuesto de ingresos.

España turo el portorium que en tiempo de Augusto subió hasta una octava parte del valor de los objetos, y el almojarifazgo ó de puertas que cobraban los 
aislados, y tienen por consiguiente la obligación de auxiliarse en sus necesidades, siendo una de las más precisas la de celebrar conciertos para dar salida á sus productos, ya naturales ó manufacturados, evitando represalias, competencias y antagonismos, y que degenere en guerra económica de oposición sistemática lo que debe ser concordia y harmonia para el fomento de intereses mútuos.

Es preciso estudiar muy detenidamente los Tratados, y «hoy que la politica económica de los Estados tiende cada vez más al abandono de los ideales fisiócratas del librecambio y en más de un caso se encierra dentro del más resuelto proteccionismo, toda mesura es poca y de toda precaución escasa

árabes sobre todos los géneros. El santo Rey D. Fernando, después de apoderarse de Sevilla dejó subsistente este derecho y determinó en el primer cuaderno las mercancias que quedaban sujetas al pago de aduanas. Los diversos aranceles que han venido rigiendo han obedeeido más que á las necesidades del Tesoro y aun que del impuesto de Tabacos, del Consumo y bastante más que á las conveniencias de la producción, álas diversas vicisitudes y á las formas de gobierno y administración del país.

Hoy la renta de aduanas, después de la contribución territorial, es la primera en nuestra nación; excede de 100 millones de pesetas el ingreso anual; más que el de la contribación industrial. 
al comprometer los intereses de la producción nacional en una lucha á la cual se presentan denonadas y pujantes las producciones extranjeras.» ( $\mathrm{I}$ )

Si el comercio es, como ha dicho Cárlos Fourier, ael arte de comprar en tres francos. lo que vale seis, $y$ de vender en seis francos lo que vale tres", con los Tratados suele ocurrir una cosa idéntica, pues como expuso el Principe de Bismark al consignar lo que significan de ordinario estos convenios cada vez que uno de los mismos queda concluso lo primero que se acostumbra á preguntar es: ¿á quién se engaña aqui, quién el engañado? Así resulta generalmente; pero no se descubre sinó al cabo de cierto número de años... Un tratado de comercio es un sintoma de feliz amistad; pero para la economia nacional lo que únicamente importa es el contenido, la substancia; y si logramos que un Estado nos compre más que nosotros á él ciertamente yo no me opondré, con tal de que no origine un gran desconcierto en nuestros asuntos interiores, y en nuestra situación actual como productores (2).

Tal es, en efecto, la esencia de los Tratados de comercio, á pesar de que se los llame

(1) Estudio de la mayoría de la Comisión del Senado disuelto al proyecto del Tratado con Alemania.

(2) Dis. pronunciado en el Reichstag. el 2 de Mayo 1879. 
de reciprocidad, ó de nación màs favorecida, cuya primera fórmula bien garantizada en la estipulación, ya es sabido que sirve para poder entablar la oportuna demanda de rescisión fundada en prueba de lesión enorme ó enormisima, y que la del trato de más favorecida equivale en la práctica á privar el derecho de reclamación ó protesta por el engaño, y á que el débil resulte más sacrificado, asi que importan poco las seductoras vestiduras teóricas, los barnicesy las rúbricas de cortesia diplomática, á que recurren en tales casos las partes contratantes para cubrir la desnudez de una triste realidad, cuando al fin que persiguen los Estados es vender el uno más que el otro y con más positivas ganancias.

$\mathrm{El}$ arte de negociar Tratados, es una de las obras más complejas y delicadas que cabe confiar á la habilidad más que á la buena fé de negociadores expertos, los cuales no pueden tener completa seguridad de haber dejado á salvo los intereses que les fueron encomendados, por más que estipulen en el convenio un plazo de muy corta duración, la reprocidad, Tarifa minima y cláusula de garantia; pues algunas naciones quedan en la Tarifa minima tan altos los derechos, que no es posible aprovecharlos, y por que la reciprocidad no existe donde hay lesion para unos intereses y favor para otros, siendo además imposible, por las muchas 
eventualidades del porvenir, conocer de antemano los resultados en las liquidaciones del tráfico internacional, aún cuando se consiga alguna supremacia, y, después de haber propuesto y concertado en las estipulaciones comerciales todo aquello que á cada nación le importa, aparezcan menos probables las perdidas que las ganancias.

Sin embargo, como no hay regla sin excepción (pues en tal caso sería una excepción de la regla), puede ocurrir alguna vez que los Tratados sean ventajos para ambos paises, porque hay productos que sobran en una nación y son necesarios en la otra $J$ vice-versa; pero aún asi toda precaución será poca y todo descuido punible para no dejarse seducir por el más meditado eufemismo.

La protección racional es un medio necesario para el fomento de los intereses nacionales.

La cuestión arancelaria es en la actualidad del mayor interés é importancia, y un factor de los más esenciales para la mejor solución del interesante problema agricola. Es el que hoy preocupa séria y profundamente á todo el pais, en particular à los productores, pues tienen su pan y sus intereses en manos de sus gobernantes.

Ocioso y prolijo sería intentar discutir el proteccionismo y el libre cambio, pues nadie 
con fundamento puede negar que el recargo del Arancel es indispensable para el fomento de la agricultura, y porque la experiencia nos demuestra bien claramente la inmensa ventaja del primero y los enormes perjuicios que el último ha ocasionado à los palses productores.

La protección es absolutamente necesaria para el fomento de la riqueza agricola y pecuaria como lo es tambièn para el del comercio, la industria y el trabajo nacional.

El libre-cambio, por el contrario, es funesto en sumo grado, porque ha impedido que el desarrollo industrial haya alcanzado mayores proporciones en nuestra pátria; es el que la ha arrebatado su crédito y su dinero, y el que ha obligado à emigrar de España a muchos de sus hijos renegando del suelo en que nacieron. Hoy ese sistema no representa otra cosa que la quiebra del Tesoro público, la ruina completa de la agricultura, el malestar de los obreros, y la perturbación en todas las clases sociales.

Es, pues, necesario defender con decisión y entusiasmo los intereses de la producción nacional, que aunque materiales, conducen á un fin moral, adoptando al efecto un régimen exclusivamente proteccionista; un proteccionismo racional, prudente, sin excesos y sin intransigencias para todos los productos del pais, pues el criterio ecléctico de 
la oportunidad debe consistir en la aplicación inmediata de las medidas más eficaces para proteger sin vacilación alguna y sin tregua ni descanso los intereses nacionales antes que los extraños.

«Entre los amigos de la protección y los del libre-cambio, se han atravesado, con fines exclusivamente de neutralidad política, los que á sí mismo se llaman oportunistas; si por oportunismo se entiende la conducta del que, renunciando á realizar de repente sus doctrinas, se conforma con aplicarlas segun la oportunidad de las circunstancias, todo libre-cambista y aún todo proteccionista puede ser oportunista.

Pero, en todo caso, hay que comenzar por tener doctrinas, para aplicarlas, segun la oportunidad. Las palabras oportunidad y oportunista, expresan un concepto adjetivo que supone y exige un concepto sustantivo á que se refiera. No son admisibles, por tanto, esas fórmulas cómodas del gobernante que dice que él no es sectario ó que no tiene preocupaciones de escuela, y afirma con gran desenvoltura que no profesa opinión determinada acerca de las mismas cuestiones sobre que legisla. Eso de resolver los asuntos sin conocimiento de las reglas que a ellos pueden aplicarse, es de todo punto inadmisible. Cualesquiera que sean las dificultades de un partido político que tiene divididas 
sus tuerzas entre los defensores de tendencias económicas contrarias, es absurda la pretensión de que en las cuestiones que llegan en momentos determinados à ser de primera y preponderante importancia, se adopten resoluciones decisivas, proclamando falta completa de criterio y haciendo profesión de no tener ideales, ni saber cuál es el rumbo y la orientación que se desea (I)n.

$\mathrm{Y}$ en efecto, hoy que todos vemos y palpamos las funestas consecuencias del librecambio; que reconocemos la necesidad de acudir con premura á salvar la riqueza agricola, base y fundamento del trabajo nacional, de la jndustria y del comercio, y la que más contribuye al sostenimiento de los servicios públicos; que vemos también que todas las naciones de Europa se manitiestan resueltamente proteccionistas y que levantan sus fronteras contra los productos extranjeros, nuestros politicos y gobernantes no han de ser tan suicidas de los intereses pátrios que no imiten el ejemplo tan hermoso, el espectáculo tan edificante que ofrecen los demás paises.

Constituido el imperio germánico sobre la hegemonia de Prusia, formando un pueblo regido por hombres eminentes y prácticos

(1) Cos-Gayón. (Disc. pronunciado en el Ateneo el 17 de llayo de 1894). 
en la noble misión de defender sus intereses nacionales, el gran Canciller Bismark, al observar en su escudriñadora mirada de estadis. ta que á los pocos años de empezar á disfrutar los cuantiosos millones pagados por Francia como indemnización de guerra, se encontraba el pais más empobrecido que antes de la victoria, se encargó personalmente de estudiar el problema económico y consolidó su obra política proteccionista elevando sucesiva y rápidamente sus Aranceles en 1879 , 1887 y en 1889. (1). El admirable resultado del severo régimen protector desarrollado con energia lo demuestran la animación y vida que se nota por todo el imperio, el inusitado movimiento de sus mercados, y la actividad tan vertiginosa en sus tres puertos de Brema, Francfort y Hamburgo, los mayores y más importantes del mundo. (2).

Francia no pudo resistir el Tratado de transacción de 1860 por la parte que tenia de librecambista, y contra el que se produjo una

(1) Su sucesor el Canciller Caprivi las ha reforzado aún y no obstante Hamturger' Machrichtem órgano del Principe Bismark censuraba en Noviembre de 1893 la política comercial por no ser lo suficiente protectora para los productos alemanes.

(2) El espiritu proteccionista ha llegado hasta tal punto en Alemania, que los Ministros recomiendan á los empleados que están bajo sus órdenes que usen solamente plumas de fabricación alemana. 
reacción unánime y violenta que ha llegado á la exageración más intransigente, comprometiendo á sus hombres políticos (I) à conservar incólume la absoluta libertad arancelaria reivindicada, por medio de la que ha conquistado el régimen protector, cuya Tarifa minima asegura al trabajo nacional la compensación necesaria para su mejor desarrollo y competir con las industrias extranjeras.

En los Estados Unidos es donde el proteccionismo tiene más hondas raices, cuyo régimen protector exagerado raya en los confines del arancel prohibicionista, y ha contribuido eficazmente al prodigioso aumento de su riqueza pública. El ingreso anual por renta de Aduanas, excede de mil millones de pesetas, que permite tener la tributación á un tipo reducidisimo y repleto de metálico el Tesoro de aquella República norteamericana.

Por legitimo espiritu de conservación y de defensa propia, sigue el mismo camino de la protección arancelaria Portugal, elevando

(1) Siendo jefe de la importante agrupación proteccionista el ilustre Mr. Méline, y á pesar de los vehementes deseos por lo mucho que interesa á la nación entera la amistad con el Imperio ruso, la Cámara de Diputados aprobó por gran mayoria, en Febrero de 1894, el proyecto de ley aumentando los derechos arancelarios sobre los trigos. 
sus tarifas en 1887 y 1888 ; Austra-Hungría haciendo lo propio en 1882 y singularmente en 1887: Suecia y Rusia observan tambier idénticas corrientes proteccionistas, y hasta la misma Inglaterra, la nación librecambista por excelencia, cuando le ha convenido, no admite ya semejante sistema, y enfrente del vetusto edificio de la escuela de Manchester, se levanta la escuela moderna, la escuela proteccionista que defiende, anhela y reclama la más decisiva protección, como la más conveniente para todos los productos é industrias de su pais.

Pues si todos los palses se manifiestan tan decididos de un régimen protector, en ninguna otra nación se impone el proteccionismo con fuerza mayor y con necisidad más apremiante que en España.

Por eso la nación entera aplaudió con la mayor efusión el Real decreto publicado en la Gaceta del 25 de Diciembre de 1890 (1), por virtud del cual, y haciendo uso el Gobierno de la autorización que le fué concedida por el art. 38 de de la ley de Presupuestos de 29 de

(1) Como tambien la ley de 9 de Febrero de 1895 estableciendo un recargo extraordinario sobre los trigos, harinas de trigo y salvado; si bien lamentando que el recargo sea solamente transitorio y reducido, en vez de definitivo y algo más elevado como deseaban los labradores. 
Junio del mismo año, derogaba defininitivamente la base $50^{2}$ del Apéndice letra $\mathrm{C}$ de la ley del Presupuesto de ingresos de $1 .^{\circ}$ de Julio de 1869 y la ley de 6 de Julio de 1882 ; elevando á la propia vez para desde $I .^{\circ}$ de Enero de 1891 los derechos de importación á los ganados y sus carnes, y à los cereales y sus harinas que se hallaban entónces libres en los Tratados; conforme á cuyo protector criterio y en vista de las propuestas de la Comisión creada por decreto de 10 de Octubre de 1889 para el estudio de la reforma arancelaria y de los tratados de comercio, formó y publicó el Arancel general de Aduanas de 31 de Diciembre de 189 I con sus dos Tarifas, la primera aplicable á las naciones que no hagan convenios especiales, y la segunda à las que concedan à España la suya minima, si el Gobierno juzga que contiene reciprocidad bastante para ésta concesión, cuyo Arancel empezó á regir desde $10^{\circ}$ de Febrero de 1892 , habiendo dado cuenta oportuna de una y otra disposición á las Córtes que prestaron su asentimiento y aprobación unánime (I).

(1) Tambien y de acuerdo con las conclusiones de la referida Comisión se denunciaron los Tratados de comercio que tenían compromisos arancelarios y terminaban en 1892; y además se declaró de cabotage, y por tanto, con derecho á ser ejercido solamente por baques espoñoles el comercio entre la Península y sus posesiones ultramarinas. 
Aquella obra verdaderamente nacional, tiene la fuerza de una ley del Reino, y está basada en ámplias informaciones, que tomaron participación las más valiosas y autorizadas representaciones de la agricultura, la industria y el comercio; en las doctrinas del Gobierno que la llevó á cabo, y en lo que venia reclamando con insistencia imperiosa la opinión pública.

Asi, que en vez de debilitar y perturbar en lo más mínimo una obra altamente provechosa para nuestras fuentes de trabajo $\mathbf{y}$ deriqueza, faltando directa é indirectamente á la misma ley arancelaria y á uno de los principios más fundamentales de la Constitución del Reino, conviene robustecerla más y más, y respetar los derechos é intereses creados al amparo de la ley; conservar cual preciado tesoro un régimen benéfico y protector á costa de tantos sacrificios reivindicado, y defender, si es preciso, con vigor $y$ energia nuestra hermosa soberania arancelaria, ante los asedios de los que pretendan destruirla ó debilitarla en detrimento de nuestros productos nacionales.

Los importantes trabajos de la Comisión informadora, contenidos en cinco gruesos volúmenes, han sido resumidos, expuestos y juzgados en un valioso dictámen con la mayor precisión é imparcialidad, y con la autoridad y competencia de que dispone el señor Vizconde de Campo Grande. 
Es así mismo necesaria para harmonizar el capital y el trabajo.

La protección es también conveniente para la buena harmonia que debe existir entre el capital y el trabajo, porque los agricultores obteniendo algunas ventajas emplearán mayor número de obreros para el cultivo de sus propiedades, como igualmente los industriales para el desarrollo de sus industrias respectivas.

De reducir al i7 el 19 por Ioo el tipo de gravamen para la tributación en la riqueza rústica imponible, la diferencia seria de una peseta próximamente por hectárea; con cuyo pequeño beneficio los agricultores no habian de conseguir ventajas considerables, pero las tendrán segúramente si se les garantiza la venta de los frutos y productos de sus cosechas á precios suficientemente remuneradores.

Las clases jornaleras nada ganan con que los artículos de consumo sean baratos, pues el aumento de una peseta por derechos de importación en cada fanega de trigo equivale á menos de O'04 céntimos de peseta en kilógramo de pan, y el de tres pesetas en el precio ó valor de un hectólitro de vino, representa el de o'03 céntimos en litro, cuyos aumentos, aunque insignificantes, al productor le permiten atender con más desahogo 
á los gastos de labores y pago de tributos, y para el consumidor suponen muy poco; pues si un jornalero necesita dos ó tres panes diarios, y un litro ó dos de vino para su consumo y el de su familia, tendrá que pagar I2 ó 15 céntimos más, pero esta pequeña diferencia la pagará con gusto segúramente, si por tal circunstancia tiene medio de ganar el sustento diario, ya que careciendo de jornal no puede comprar ni caro ni barato.

Bien claramente lo afirman los obreros catalanes en su adhesión ( 1 ) á los industriales y obreros de Vizcaya, Asturias y Cataluña, impugnadores de los Tratados de comercio con Alemania é Inglaterra.

"Por lo demás, las clases jornaleras no han menester precisamente que los productos de su consumo sean baratos; lo que necesitan es que haya abundancia de trabajo, y ganar el salario correspondiente, para poder comprar caro ó barato los artículos que necesiten. Bien patente es el ejemplo de todos cuantos paises la vida del obrero es barata, los salarios son reducidisimos, viven sin comodidades, arrastrando una existencia miserable, sinónimo de exclaros. Por el contrario, donde la vida es cara, los salarios son elevados, disfrutan de muchas más comodidades, pueden ahorrar, el dinero

(1) De 23 Diciembre 1893. 
circular, el comercio y el movimiento aumenta, la agricultura encuentra el mercado rico, y el propietario urbano también prospera porque las fincas y los terrenos aumentan de valor por las pingües rentas".

$Y$ en verdad, el malestar de una clase no puede menos de repercutir en la situación de la otra, particularmente en lo que afecte á la clase agraria, pues los trabajadores del campo suelen ganar menos que sus hermanos los obreros de fábricas, y sin embargo únicamente ansian una ocupación constante.

El buen obrero, el que es verdadero trabajador, amante del hogar y de la familia, y se propone cumplir con la condición fundamental de la existencia del hombre, cual es el trabajo, sólo se cuida de ganar el pan cuotidiano con el sudor de su frente, sin casi abrigo, ropas ni calzado y una alimentación insuficiente por un jornal súmamente escaso que el productor, bien á su pesar, no puede elevar por la depreciación á sus frutos ó géneros, y muchas veces por no tener salida á los mismos. Aunque agobiado por el trabajo y ábatido por la pobreza, lleva su suerte con resignación, sin atender consejos insanos, ni seguir los malos ejemplos que vé por doquier. Ese obrero modelo, verdadero anacoreta, sobre todo el de buena fé, el que pone para el cumplimiénto del 
deber cuanto está de su parte, merece el cariño y la protección de propios y extraños, y es acreedor á que se le haga pública manifestación de simpatía y testimonio, de consideración y aprecio. Es e! que mejor cumple la ley impuesta por Dios por el pecado del primer hombre, y se conforma con tener salud, pan y trabajo; aspiración sublime, idea grandiosa, deseo noble, petición honrosa que tanto eleva, dignifica y ennoblece á los que la sustentan y que debe ser atendida por medio de una protección decidida á los intereses nacionales, en particular álos agricolas, que son hoy los que más la necesitan; pues el ejercicio es sano, y el trabajo constituye á la vez pan para el cuerpo y el espiritu.

Además, es preciso dirigir la vista al campo, de donde pueden venir las virtudes que tanto escasean, y que se pretende buscar, acaso en vano, por otras vias. Por lo tanto, todo cuanto conduzca al desarrollo del trabajo nacional, será patriótico y laudable, y conviene no olvidar que el verdadero cimiento de la riqueza pública es el trabajo del hombre.

«El trabajo propio, incesante, multiplicado, puesto á la altura de nuestras necesidades y de nuestras deudas nos podria aún salvar. Pero sigan los libre-cambistas á las claras ó con cautelas sus operaciones, triunfen, y habrá que abandonar toda esperanza. 
Faltará en España el trabajo y faltará al propio tiempo con qué comprar el pan sea castellano, sea extranjero. Los no muchos ricos hasta aqui dedicados á la agricultura y la industria, las abandonarán para convertirse exclusivamente en prestamista del Gobierno, y el socialismo revolucionario y el anarquismo no perderán nada seguramente. La sociedad española será quien pierdaw (I).

Los cambios internacionales.

La pavorasa cuestión de los cambios sobre el extranjero ha llegado à preocupar séria y profundamente á todos los que se interesan por mejorar el estado de nuestra aflictiva situación económica.

Los tratados de comercio sino constituyen el único y exclusivo regulador del cambio, así como tampoco los problemas monetarios, son los que pueden corregir la subida del mismo de un modo más eficaz y directo.

Siendo cuestiones de naturaleza tan abstrusa como expone el Sr. Sánchez de Toca en el prólogo de una de sus obras (2) «que hasta aqui constituyeron la especialidad de

(1) Tal es el hermoso remate del notabilísimo artículo del Sr. Cánovas del Castillo, que, respecto á la cuestión arancelaria, é instado por el director de $E l$ Imparcial, publicó éste el 8 Junio 1894.

(2) La plata, el oro y los cambios. 
corto número de iniciados, se han convertido sin embargo, de improviso en asuntos por los cuales tan vivamente se apasionan los ánimos, que rara vez se examinan con la debida serenidad de juicio. Y es que los problemas monetarios y los del cambio internacional encierran hoy las quintas esencias de toda especulación práctica y teórica de la economía política. No hay ningún interés económico ó social al que no afecten hondamente: ejercen trascendentalísima influencia sobre el comercio universal; traducen los principales enigmas de las crisis; agitan á los mercados como los más importantes y actiros de sus factores económicos; de ellos dependen la prosperidad y calma de la vida comercial é industrial; ellos son à la par los agentes que engendran los más formidables ciclones perturbadores de la producción y del consumo, y en ellos también se engerentra con frecuencia el secreto de muchas conflagraciones y angustias que figuran como inesplicables en el régimen de los salarios; lo abarcan todo, en fin, en la economia social y en todo repercuten".

Con efecto, los problemas monetarios, los del cambio internacional y los tratados de comercio todo abarcan y en todo repercuten, siendo hoy una de sus fases más importantes, complejas y dificiles de resolver la relativa à los cambios. 
Mucno se ha estudiado el fenómeno mercantil de la elevación de los cambios, sin que hasta el presente se haya conseguido otra cosa que conocer algunas de las causas y columbrar el remedio, pero á distancia tan larga que no es posible llegar sin la unión y el concurso de todos los españoles.

Los Gobiernos, ya sean conservadores ó liberales, no pueden en poco tiempo hacer descender los cambios, porque éstos obedecen á las leyes que regula al comercio, á las relaciones con los demas paises y á multitud de contingencias de indole diversa.

Si intentamos comprobar la causa generadora de la elevación de los cambios, tendremos por resultado que aquella no es otra que el desnivel de la balanza mercantil; y si el nivel de los cambios ha de buscarse únicamente en la nivelación del debe y del haber de cada pais, nos dará como consecuencia inevitable del mismo resultado, que siendo en el nuestro la importación mayor que la exportación, tenemos que pagar al extranjero $100, y$ recibir del mismo 50.

Así lo reconoce el distinguido publicista Sr. D. Juan de Dios Blas al afirmar que: «el cambio es el principio de la reacción económica y sirve para hacer notar al pueblo que le satisface que su consumo es mayor que la producción, que gasta más que medios tiene ó cuenta, que ha perdido la moneda de oro, 
ủnica que evita el cambio y freno al comerciante para que su interés individual al hacer las compras en el exterior, no perjudique al interés general, y el por fin el que enseña y corrige á los Gobiernos y pueblos que descuidan la defensa de la producción nacional, con cuyo lamentable proceder parece que olvidan que cada fábrica que se abre, ó cada. industria que se monta, es una mina de oro que se descubre, y los productos, moneda de ese metal que vienen á la nación del extranjero, si se venden esos productos al mismo, ó impiden que se vayan si se consumen en la nación».

Pues bien, siendo cierto é indudable quela causa principal de la subida de los cambios consiste en que el valor de lo que exportamos es mucho menor que el valor de lo que importamos, por lo cual tenemos quepagar más al extranjero por sus mercaderias, que lo que este paga por las nuestras, conviene adoptar desde luego las medidas conducentes para contener, ya que no evitar en absoluto, los estragos que el mal ocasiona; pues diagnosticada una enfermedad, procede aplicar con la urgencia que el caso requiera los remedios terapéuticos indicados para curarla ó siquiera aliviarla en vez del laissez faire, laissez paser y del nolite me tángere que equivaldría en este caso á consentir que el mal se agravase en mengua y 
aun peligro de nuestra independencia económica.

El régimen arancelario

es el mejor correctivo de los cambios.

Favorecer la producción nacional en el interior y dirigir al exterior las corrientes del tráfico, dará el resultado apetecido, á cuyo fin ael arancel aduanero es, en efecto, el gran instrumento de defensa y protección económica de las naciones, y el más eficaz de todos los correctivos del cambio internacional, porque con más energia que cualquier otro remedio actúa directamente sobre las causas que producen la situación de nación deudora. Además son los tratados de comercio el natural complemento de la politica arancelaria, encaminada á corregir ó prevenir el quebranto de los cambios internacionales, y aun á saldar favorablemente, en cuanto se pueda, la balanza económica. El fin capital de este género de tratos, y lo que justifica sus negociaciones es buscar mercados extranjeros donde colocar los sobrantes de la producción nacional, á la par que procurar à esta baratura de las primeras materias que necesita para el fomento de sus fuerzas productoras. Cuando esto se logra en las negociaciones comerciales, bien puede úecirse que los tratados de comercio son el 
mejor correctivo de los cambios, y remedio más eficáz para una situación económica de nación deudora, con las circunstancias en que la nuestra se presenta. Pero tambien resulta evidente que éste es de los remedios de más delicada, difícil y arriesgada aplicación; porque así como un tratado puede ser fruto de excelente política, si procura aumentos á la exportación conquistando las ventajas de algun mercado extranjero, para la producción nacional, nada más fácil asimismo que, por cualquier error de negociadores, á la noción que creía encontrar nuevos mercados le toque, por el contrario, el papel de víctima, y el tratado sólo le sirva como nueva causa de desangramiento, que la lleve á más extremada pobreza (I)».

$Y$ en verdad, los tratados de comercio, siendo buenos, pueden influir de un modo ostensible y directo en el mejoramiento de los cambios; pero si aquellos en vez de favorecer la exportación, la perjudican, y son la causa de que la importación aumente de una manera considerable, entónces pueden servir para acabar pronto con la riqueza pública y precipitar al pais en la más espantosa ruina; pues como con fundada razón asegura el expresado Sr. de Dios Blas: «una nación que exporta al año 400 millones de

(1) Sánchez de Toca en su obra ultimamente citada. 
pesetas, é importe mas de 1.000 millones sepuede arruinar y empobrecerse. Como que la primera en diez años puede haber traido del extranjero 1.000 millones de pesetas, y la segunda haber perdido 2.000 en ese tiempo.

Es una ceguera incurable en gobernantes y gobernados, el creer que nivelando el presupuesto del Estado solamente y cortando en absoluto el déticit, ya está resuelta la cuestión económica. Pero, ¿y el déficit del presupuesto de las necesidades de todos los españoles, que es mucho más grande que el del Estado, y que se cubre por el extranjero á costa de nuestra riqueza monetaria j́ fiduciaria? ¿No hemos visto que ha hecho más extragos en nuestra moneda el déficit de la nación consistente en productos, en servicios de ferro carriles, tranwias, alumbrado de gas y electricidad, teléfonos, sociedades de seguros, servicios de Banco, y otros mil y mil que nos prestan los extranjeros; que el déficit del Estado que ha originado los intereses de la Deuda exterior? Evita que porque el presupuesto del Estado este nivelado y con sobrante no vaya poco á poco disminuyendo la riqueza monetaria y fiduciaria en favor del extranjero, hasta que vaya todo á su poder?

Exactísimo; si hay 100 millones de diferencia en más á favor de la importación, 
como hubo en el último año económico, esos Ioo millones han salido de España, con más 80 millones por intereses y cambios del cupón dt nuestra Deuda exterior; los que han obtenido por productos liquidos las grandes empresas ferroviarias, cuyas acciones y obligaciones pertenecen á los extranjeros; los de las minas de Somorrostro y Almadén, las primeras propiedades de belgas é ingleses y las últimas de Rotschild; y los de los importantes servicios ya insinuados, que con el sobreprecio del cambio, representan una exportación metálica anual de más de 300 millones; de manera que noes posible que una nación pobre como lo es la nuestra, recaude todos los años 300 millones de pesetas para mandarlas al extranjero.

Para contrarrestar la cifra de la importación, teniamos en los vinos una partida considerable. En el quinquenio anterior á la terminación del Tratado con Francia, ó sea desde 1887 hasta I 891 , sólamente en los vinos comunes, hemos tenido una contrapartida á favor de la exportación de más de I. I00 millones de pesetas. Ahora que apenas exportamos vino, porque Francia que era la que más nos compraba, ha conseguido la regeneración vitícola y un aumento considerable en sus cosechas (1), de más de 20 millones

(1) Si bien la de 1895 ha sido más reducida que las de los años anteriores. 
de hectólitros, es de necesidad apremiante ensanchar el mercado interior, y sin desatender el de aquella nación, buscar mercados extranjeros para nuestros productos, sobre todo para los vinos que son los que más lo necesitan (I).

El remedio de los cambios, - como dice el célebre Canciller británico Goschen (2), no puede hallarse sinó nivelando la balanza de importaciones y exportaciones, nivelación que sólo se alcanza enfrenando la suscripción de nuevos compromisos internacionales; es decir, alterando las corrientes del comercio, pues es evidente que cuando una nación importa y consume más de lo que exporta y gana, se precipita necesariamente en una situación deudora que no es posible remediar sinó consumiendo ménos y produciendo más.

Así, pues, evidenciado que la protección es un remedio eficaz para corregir la elevación de los cambios y favorecer al propio tiempo los intereses nacionales, es un deber

(1) En atención á las graves circunstancias porque atraviesa la riqueza vinícola, nos ocupamos con más detenimiento de tan importante particular en la Parte 2.", cap. I.

(2) En su obra fundamental Teoría de los cambios extranjeros, traducida al castellano por el Marqués de Villariciosa de Asturias. 
patriótico y apremiante en los Gobiernos españoles, adoptar un criterio eminentemente proteccionista para poder sostener la com. petencia extranjera, á la vez que para dar salida á los productos del pais.

La protección, es asi mismo necesaria para transformar la agricultura, industria y comercio, fomentar el trabajo, contener la emigración y consolidar nuestro crédito.

La importación de substancias alimenticias ó de productos manufacturados de igual clase que los que el país produce, es en perjuicio de la producción, de la industria y del trabajo nacional, y que á más de arruinarnos, nos desacredita ante los demás paises. El dinero que se manda al extranjero no vuelve á España, y como lo que de aquél se adquiere no se paga en billetes, ni con valores fiduciarios, de continuar consumiendo productos de otras naciones, terminarán por llevarse nuestra plata, como se han llevado nuestro oro.

Ya que el estado de nuestro Tesoro no permite por ahora la rebaja de tributos, ni con ella habian de tener completo remedio los males que la nación lamenta, y sin perjuicio de que se construya mayor número de carreteras, vias férreas y canales para transportar nuestros productos á los principales mercados, conviene adoptar un severo régimen protector que encauce hacia los centros 
de la producción nacional las corrientes de consumo que han enriquecido á los industriales extranjeros.

Fomentar y proteger el trabajo nacional para que resulten más favorecidos los productos de nuestra nación que los extraños, pues mientras otras naciones se muestran decidamente protectoras de sus intereses, no ha de haber en España menos patriotismo para favorecer la riqueza agricola y pecuaria desechando ideas absurdas que redunden en perjuicio de los intereses pátrios; pues no es lo mismo dejarse arrastrar por la bella perspectiva del idealismo que descender al estudio y análisis de los hechos, los que, segun Montesquien, tienen siempre más fuerza que las palabras; lo cual es exacto, porque la retórica nunca puede lograr la persecución y eficacia de los nombres y de las cifras.

Es menester además ensanchar nuestros mercados interiores, y que productores $y$ consumidores que vienen á ser unos mismos, se ayuden reciprocamente, debiendo conformarse los primeros con unos preciosos remuneradores y los últimos preferir los productos nacionales caros ó baratos, malos ó buenos, comprando lo menos posible del extranjero.

Por último, es necesario tambien que tanto gobernantes como gobernados y lo mismo productores que consumidores, imiten el 
ejemplo que nos dan las demás naciones, y se persuadan todos que en estas cuestiones no se disputan intereses y derechos entre escuelas y partidos españoles, sinó entre la pátria y los paises extraños, y que las circunstancias de actualidad imponen á todos los españoles el deber de formar estrecha alianza para la defensa de los intereses nacionales. 


\section{CAPITULO VI.}

De la contribución Territorial.

1. Necesidad apremiante de rectificar los amillaramientos actuales.

2. Diversos médios de ocultar riqueza.Desigualdades irritantes en la tributación.-El catastro.

3. Las cartillas evaluatorias.-Cómo y quienes deben formarlas.

4. Comisiones especiales para efectuar la clasificación de cultivos, y la calificación de fincas.-Reformas indispensables.

5. Las heladas y las sequias deben ser consideradas como calamidades para obtener el perdón de la contribución Territorial.

6. Conveniencia de crear una caja nacional de calamidades.

Los antíguos y heterogéneos tributos que más ó menos directamente pesaban sobre la propiedad inmueble, y cuya supresión fué un bien inmenso para todas las clases contribuyentes, vinieron á refundirse en la contribución directa Territorial. Las bases son generales y uniformes para todas las provincias, 
pueblos y contribuyentes; sin que nadie haya dudado un momento siquiera de las ventajas de tan radical reforma, y cuyo sistema tributario desarrolló en 1845 el gran ministro de Hacienda D. Alejandro Mon (1).

Los amillaramientos formados en 1860 , reconocidos como defectuosos y equivocados continuan vigentes en la inmensa mayoria de los pueblos, y su rectificación inmediata, ó la formación de otros nuevos, es una necesidad que se impone por sí misma para llevar á todos y cada uno de los pueblos la igualdad tributaria posible.

La reforma de un amillaramiento verdad ó aproximado á ella es además necesaria

(1) Las Córtes celebradas en Bribiesca en 1388 mandaron valuar todos los bienes muebles y raíces, $y$ en proporción á los productos, se les impuso una contribución.

Felipe V. para atender á los gastos de la guerra de sucesión, acudió al arbitrio de la contribución directa.

En 10 de Octubre de 1749 expidió Fernando VI un decreto por virtud del cual se establecía una sola con tribución sobre los productos de los bienes sujetos hoy á la contribución Territorial.

Por Real decreto de 4 de Julio de 1770 suprimió Cárlos III un gran número de rentas, y mandó que se llevase á efecto la única contribución directa; más por efecto de los cambios y vicisitudes porque ha atravesado la Administración del país, no ha podido establecerse como definitivo hasta el referido año 1845. 
para descubrir mejor por tal medio la mucha riqueza que aún permanece oculta, y particularmente la que está mal calificada y clasificada, corregir enormes defectos y reparar muchas notorias y muy irritantes desigualdades.

Individuos que murieron hace 25 ó 30 años figuran como contribuyentes en amillaramientos y repartos: muchos de los actuales poseedores carecen de documentos escritos fehacientes, pues la prohibición expresa para las traslaciones por los verdaderos adquirentes y herederos para acrecentar los derechos del Tesoro, han dado resultados contraproducentes, (1) porque los interesados huyendo de los crecidos gastos que supone el papel sellado, derechos notariales, reales y de inscripción, no han formalizado los traspasos

(1) Asi que encontramos mas factible y de mejores resultados para el Tesoro dejar campo libre para las alteraciones en los amillaramientos de la riqueza inmueble, sin el prévio pago de los derechos á la $\mathrm{Ha}-$ cienda, estableciendo solamente para los Presidentes de las Comisiones de evaluación, y juntas periciales la obligación ineludible de dar noticia en el mismo día al liquidador respectivo conforme al art. 170 del reglamento sobre el impuesto de derechos reales de 25 de Septiembre de 1892, sin más restricciones; con lo cual se conseguirá más fácilmente aquel objeto, logrando además la Administración, por tan sencillo medio, importantes datos que pudiera utilizar para otros fines; 
de dominio. Otros han efectuado las ventas por virtud de contrato verbal, ó de documento privado, obligándose los compradores á pagar la contribución, pero como tales particulares no constan en los apéndices ni repartimientos, los recaudadores y agentes ejecutivos no saben contra quién ó quienes han de dirigir las reclamaciones y apremios, la $\mathrm{Ha}$ cienda no percibe á tiempo las cuotas de contribución y nunca lo que se defrauda en cédulas personales, que no es poco, pues. como algunos poseedores de fincas no aparecen en contribución, procuran arreglarse con una cédula de clase oncena (por no haberla de más bajo precio) como si fuesen jornaleros ó sirvientes.

Durante el transcurso de 36 años se han alterado las cabidas, asi como la clasificación de las fincas, produciendo importantes alteraciones en la riqueza imponible, sin que los

á la vez que aumentar las rentas del Tesoro facilitando la instrucción de multitud de expedientes posesorios; pues aun cuando estos pueden formalizarse sin que se hallen amillaradas las fincas ó lo estén á nombre de otra persona que no sea el solicitante, conforme á las Reales órdenes de 14 de $.1 a r z o$ y 14 de Junio de 1884 , es un medio costoso y molesto la anotación preventiva y la conversión de aquella en inscripción definitiva; siendo más fácil, sencillo y económico para los interesados acudir á la inscripción directa, cuyo medio le daría el nuevo amillaramiento. 
apéndices orienten lo más minimo, acerca de tales variaciones. Los Ayuntamientos y Juntas periciales en los pueblos y las Comisiones de evaluación en las Capitales de provincia, no pueden hacer otra cosa, con arreglo à las disposiciones legales vigentes, que continuar figurando en los repartimientos como contribuyentes á individuos que no existen, y á los que tienen fincas que no pueden ser identificadas, porque los linderos ya no rigen, efecto de que las propiedades colindantes han pasado al dominio de dueños diferentes ó porque en los apéndices se cambiaron los nombres de los parajes ó linderos sin las explicaciones oportunas, ya que muchos terrenos estaban destinados á cereales y algunos yermos han sido transformados en frondosas viñas, y ya que otros antes productivos han convertido en campo erial y estéril las inundaciones, las heladas, sequias, la langosta y la filoxera:

Para dar una ligera idea del estado tan anómalo y lamentable en que se encuentran los amillaramientos y apéndices, transcribiremos un párrafo de la resolución de la Dirección general de Contribuciones directas de 31 de Diciembre de 1891 , autorizando al Ayuntamiento de Carabanchel Alto, para confeccionar un nuevo amillaramiento.

-Vista la instancia, fecha 21 del corriente, elevada por el Ayuntamiento de Carabanchel 
Alto, solicitando se le autorice para formar un nuevo amillaramiento, fundándase en que desde el año de 1860 no se ha confeccionado dicho documento; en que de los 330 contribuyentes por territorial que figuran en el reparto actual, vários han fallecido, otros han dejado de ser contribuyentes, muchos lo son y no figuran y los restantes han sufrido alteraciones tales en su riqueza, que hacen que el amillaramiento resulte lleno de: errores; y por último, en que dicha Corporación se halla en una situación difícil por las equivocaciones en que puede incurrir al hacer el repartimiento y la imposibilidad de cumplir otros servicios, como el de expedir certificaciones de señalamiento de fincas por débitos de contribuciones.

Y nunca mejor que en este lugar cuadra el conocido adagio: «el que vé un punto, vé todo el mundos, que aplicado al caso, es lo mismo que decir: lo que sucede en Carabanchel, ocurre también en todos ó casi todos los pueblos de España.

El estado tan crítico y deplorable del interesante servicio de la estadística Territorial, es en perjuicio de los contribuyentes y de la Hacienda pública; los primeros, porque no pueden saber con certeza el líquido imponible correspondiente á cada finca, ni suplir la titulación de sus propiedades, ni pagar por fincas que no saben fijamente si son ó no 
suyas, ó que las tienen subdivididas con diversos dueños ó partícipes, y unos pueden pagar y otros no. Para la Hacienda porque además de no percibir con puntualidad las cuotas debidas, le son adjudicadas fincas que, si poco utilizan à los interesados, al Tesoro menos; se repiten los embargos de las mismismas fincas por descubiertos de vários años de contribuyentes inciertos, y después se adjudicaná otros propietarios con linderos diferentes, viéndose posteriormente despojados de tales fincas los que las han adquirido en la creencia de que procedian de contribuyentes morosos; resultando de tanta confusión y desbarajuste, que ni los contribuyentes, Juntas periciales, recaudadores, agentes, ni la Hacienda, saben á qué atenerse.

Es, pues, de necesidad acudir con premura al remedio de tal cúmulo de errores y arbitráriedades para evitar enormes perjuicios á los contribuyentes y al Tesoro mismo, así como también el desprestigio del tributo. principal que figura en los presupuestos del Estado; de esa contribución que grava la propiedad rural, su explotación ó cultivo y la ganadería, y constituye el recurso de mayor entidad, la más importante de todas las rentas del Estado.

La rectificación de amillaramientos que se dispuso por Real decreto de 10 de Diciembre de 1878 , de haberla terminado con los 
Registros que se exigian hubiera sido un gran adelanto, puesto que equivaldrá á un catástro sencillo, de cuyo beneficio y conforme á la ley de 3 ı de Diciembre de 1881 , disfrutan algunos pueblos (aunque pagando mayor cantidad á razón del 16 que antes al 2i por roo) que en sus cédulas declaratorias han presentado aumento de riqueza; pero no así la inmensa mayoria de los 9.287 Ayuntamientos de España, en cuyos términos municipales no aparece con más riqueza que la que consta en los amiliaramientos actuales (I).

(1) Otra desigualdad bien notoria.

Para contribuir aparecen los pueblos divididos en dos secciones.

Primera, ó de favorecidos. Los pueblos que han ocultado riqueza anteriormente, y los que en la actualidad conociendo los buenos resultados del sistema, tienen todavía oculta la nayor parte de aquella, porque en vez de haber aumentado 100 , por ejemplo, lo han hecho solamente de 25 , con cuyo pequeño aumento la Hacienda se conforma, y tributan hoy á razón del $15^{\circ} 50$ por 100 en la riqueza rústica y pecuaria, y al $17 \cdot 50$ la urbana.

Segunda, ó de perjudicados. Los que en 1860 procedieron con franqueza, dijeron la verdad, han venido pagando lo justo, ó tal vez más, ya por errores ó defectos cometidos en las operaciones, ya por haberse incendiado algún edificio que no ha sido reedificado, 6 ya porque alguna plaga, crecida de rio, arroyo, inundación, etc., ha devastado algunas propiedades 
Diversos modos de ocultar riqueza.-Desigualdades irritantes en la tributación.-El catastro.

La riqueza oculta-debe pagar lo justo, y las disposiciones dictadas hasta ahora y todas las que se dicten después encaminadas á tal fin, serán muy loables; pero convendrá disfruten igualmente de tal beneficio, aun cuando sólo sea por determinado número de años, los contribuyentes de buena fé y los que pagan más de lo que debieran por error en la clasificación ó cabida ya que en tal caso habrá de repartirse el cupo entre más riqueza, con cuyo aumento sería menor el tipo de gravamen, y los Gobiernos tendrian en aquellos mismos contribuyentes auxiliares acti₹os, eficaces y gratuitos, mas si la riqueza que se descubra ha de redundar en beneficio exclusivo del Tesoro, el contribuyente honrado procurará convertirse también en ocultador, pues sabe que mientras dure la ocultación nada ha de pagar, y aun cuando se descubra el fraude, siempre quedará con ventaja por lo que antes hubiere dejado de contribuir.

Tres medios existen de ocultación. Una de riqueza, otra de cultivos, y otra de clases feraces, sin que las reclamaciones extraordinarias de agravios hayan prosperado, y sin embargo continúan con el crecido tipo de gravamen de $20^{\prime} 25$ por 100 la riqueza rústica y 23 la urbana. 
ó calidades (sin contar la de errores en las operaciones aritméticas el formar los repartos): asi que no solamente hay ocultación de riqueza porque no haya sido declarada por los dueños, sino que hay muchísima que no contribuye con lo que debiera por efecto de la mala clasificación de cultivos ó por estar calificada como de tercera clase la que es de segunda y aun de primera.

De la ocultación de riqueza por el primer medio son principalmente culpables los dueños declarantes; de las dos últimas, que en muchos casos son de más interés que la primera, lo son los Ayuntamientos y Juntas periciales ó Comisiones de evaluación.

La desigualdad del reparto y del gravamen estriba más que en la ocultación de la riqueza, en las malas calificaciones y clasificaciones.

El siguiente ejemplo aclarará mejor nuestro aserto.

Un contribuyente tiene declaradas 100 hectáreas de tierra à cereales.

La calificación que corresponde; es la siguiente:

$$
\begin{aligned}
& \text { De } 10^{a} \text { clase. . . . } 20 \\
& \text { > } 2 . .^{a} \text {. . . } 30 \\
& \text { " 3." } \gg \quad . \quad 50
\end{aligned}
$$
táreas que al tipo de la cartilla evaluatoria daria este resultado: 


\begin{tabular}{|c|c|c|c|c|}
\hline $\begin{array}{c}\text { Número } \\
\text { de hectáreas. }\end{array}$ & CLASE. & Tipo de la cartilla. & \multicolumn{2}{|c|}{$\begin{array}{l}\text { Riqueza imponible } \\
\text { PTas. CTs. }\end{array}$} \\
\hline 20 & $1 .^{2}$ & $x+5,08=$ & 921 & 60 \\
\hline 30 & $2^{8}$ & $\times 27,37=$ & $8_{2 I}$ & 10 \\
\hline 50 & $3 .^{8}$ & $\times 11,27=$ & 563 & 50 \\
\hline Total 100 & & & $2.31,6$ & 20 \\
\hline \multicolumn{5}{|c|}{$\begin{array}{l}Y \text { sin embargo de la } \\
\text { calificación en amillaramlento resulta }\end{array}$} \\
\hline 6 & 1.8 & $\times 45,08=$ & 270 & 48 \\
\hline 10 & $28^{8}$ & $\times 27,37=$ & 273 & 70 \\
\hline 84 & $3 .^{8}$ & $\times 11,27=$ & 946 & 68 \\
\hline Total 100 & & & I. 490 & 86 \\
\hline \multicolumn{5}{|c|}{ FESUMEN } \\
\hline \multirow{2}{*}{\multicolumn{3}{|c|}{$\begin{array}{l}\text { Las } \text { oo hectà reas de tierra á ce- } \\
\text { reales bien calificadas, darian } \\
\text { de riqueza imponible.. . . } \\
\text { Las mismas, mal calificadas.. }\end{array}$}} & 2.306 & 20 \\
\hline & & & 1.490 & 86 \\
\hline \multicolumn{3}{|c|}{ Diferencia ú ocultación. . . } & 0.815 & 34 \\
\hline
\end{tabular}

Como se vé por el ejemplo anterior (sin exageración de lo que suele ser frecuente en tales casos y en el que nada se figura à hortalizas, ni ı egadio, cuyo tipo de gravamen es mucho más elevado) la extensión superficial es exacta, y sin embargo existe una ocultación de riqueza imponible de más de un cincuenta por ciento por consecuencia de estar mal calificada la propiedad contributiva. 
Otro tanto puede decirse respecto á la mala clasificación de cultivos, pues aparece en amillaramiento como destinado á erial lo que es dehesa, y á cereales como tierra de tercera lo que es viñedo, praderas ó regadio etcétera.

Lo propio sucede con la fincabilidad urbana. Muchas casas, bodegas, fábricas y almacenes de sólida y moderna construcción, pro. ducen y son susceptibles de producir más renta aún, y sin embargo pagan menos contribución que otras de peor clase, cuya producción es más reducida.

Multitud de errores con intención y sin ella, existen en los amillaramientos actuales; errores que son de importancia y que es necesario desaparezcan por resultar en perjuicio del Tesoro y de los contribuyentes de buena fé, en particular de los de la clase media é inferior, los cuales por su escaso número de predios ó de ganados, nada han podido ocultar, y cuyos insignificantes productos son bien conocidos, los que más se discuten y á los que más se acusa (por lo mismo que son los más modestos), en el momento de calificar y clasificar las fincas.

Más que á la riqueza oculta no declarada por los dueños (cuya afirmación admitimos, aunque no hasta la altura que otros pesimistas exagerados), conviene atender á las malas clasificaciones y calificaciones. 
Evitando las tres clases ó medios de ocultación de riqueza, podria aumentarse en una parte considerable la masa de utilidades que hoy sirve de base á la derrama contributiva; de lo cual se conseguiria la tan ansiada nivelación de las clases tributarias, y la disminución del gravamen, quizá hasta reducirle al tipo de 12 por 100 que era el que se pagaba en i 845 .

El amillaramiento seria además una fiscalización moral y simpática; una estadística verdad para conocer las fuerzas tributarias del pais.

Urge pues llevarle á cabo en todos los pueblos, sin excepción alguna, sin perjuicio de la comprobación debida á los pueblos en que haya fundadas sospechas de haberse cometido ocultaciones, ya en la cabida, ya en la clasificación, ya en la calificación de las propiedades.

No admite duda de que es empresa algo difícil y que requiere constancia y poderoso esfuerzo la de llevar á cabo una verdadera y completa estadistica de la riqueza inmueble; pero para conseguir tan importante fin, sin tantas dificultades, conrendrá simplificar el procedimiento hasta ahora seguido para que el nuevo amillaramiento resulte sencillo, abreviado, preciso y exento de una extructura complicada, sobre la base de las cédulas presentadas, en virtud del mencionado 
reglamento (I), rectificandolas préviamente para que aparezcan en ellas los nombres de los verdaderos dueños actuales, depurando y subsanando los errores que contengan sin perjuicio de la comprobación insinuada á costa de los pueblos y contribuyentes que resulten ocultadores.

Los amillaramientos actuales son la causa de las desigualdades tan irritantes que se notan en la derrama de la contribución; el principal obstáculo para que el Gobierno conozca la riqueza llamada á contribuir y de que los agricultores consideren, con muy fundada razón, poco equitativas las cuotas gravadas á sus fincas; asi que mientras aquellos no se rectifiquen como corresponde, subsistirá la desigualdad del gravamen entre los contribuyentes de buena y los de mala té: entre los que tienen toda su riqueza amillarada y los que conservan aún ocultas importantes propiedades; entre los que la tienen clasificada y calificada con perjuicio evidente y los que han logrado una clasificación y calificación ventajosa; entre los que se someten al cumplimiento de la ley, y los que buscan medios para eludirla.

El nuevo amillaramiento puede servir tambien de preparación para formar más

(1) A tin de no ocasionar nuevos gastos y molestias á los contribuyentes. 
adelante el catastro estadístico de la riqueza inmueble, con todos los requisitos, formas y procedimientos cientificos que una obra de tal magnitud exige y requiere. (I).

El único catastro que España posee es el efectuado á fines del siglo anterior por el marqués de la Ensenada, para cuya colosal obra se consumieron grandes caudales, sin haber logrado obtener un amillaramiento completo por la resistencia de los contribuyentes contra la contribución proyectada. Por otra parte, la transformaciún que desde entónces ha sufrido la propiedad por las muchas ventas, permutas, ensanches y subdivisiones de fincas, hace que aquella obra $\tan$

(1) Cuya obra árdua y lenta ha de ofrecer graves dificultades, habiendo costado a Francia un siglo y cnatrocientos millones.

El folleto publicado en 1879 por el distinguido estadista D. Antonio Lopez, contiene soluciones claras y precisas para llevar á efecto el catastro de la riqueza territorial.

En el luminoso informe de D. Angel del Monte á la Comisión creada por Real decreto de 7 de Julio de 1887 para estudiar las causas de la crisis de la agricultura y de la ganaderia, sobre formación del Catastro, clasificado bajo el triple objeto científico, fiscal y jurídico, calcula que la operación designada con el nombre de avance catastral podría llevarse á efecto en tres años con un gasto de 5 á 6 millones de pesetas. (Tomo V.) 
monumental solo sirva ya de valioso antecedente de consulta, pero sin resultados prácticos para la tributación.

Las cartillas evaluatorias.-Cómo y quienes deben formarlas.

Para llevar á efecto la formación de los amillaramientos, conviene dar principio por las cartillas de evaluación.

Las cartillas vigentes son las que sirvieron de base para el amillaramiento de 1860 , en cuya época los productos en general alcanzaban un valor mucho más elevado que el que tienen ahora, á la vez que han aumentado los gastos de cultivo; por locual, los tipos fijados en aquellas no deben continuar por mas tiempo sirviendo de norma para la derrama. de la contribución Territorial.

Deben formarse por regiones y por personas imparciales y competentes, pues es un grave error el imponer la unidad de evaluación en un país como el de España tan variado en calidades de terrenos, climas, cultivos. y productos.

Tambien debe fijarse la verdadera fertilidad de la tierra y admitirse por lo menos cuatro clases; no porque sea el término medio entre las tres de ahora y las cinco que anteriormente se establecieron para cada cultivo, sino porque estimamos necesarias las 
cuatro clases, para que cada propietario tribute por los productos que en realidad tenga y no por los de otras zonas más ó menos inmediatas, y adaptarlas más que á la unidad y á un plan puramente fiscal, à la variedad de las diversas calidades de los terrenos, depurando en todos sus detalles los verdaderos gastos y productos.

De conferirse tan importante servicio à una Comisión facultativa (I) podrá objetarse que el estudio agronómico de cada terreno en las diversas zonas y cultivos, como tambien los trabajos minuciosos de planos perimetrales y parcelaciones, $y$ otros ensayos cientificos requieren un tiempo indefinido, $y$ que por lo aparatosos y complicados además de ocasionar considerables gastos al Tesoro público, no habrá de conducir en muchos años á ningun resultado práctico, siendo así que el mal no admite la menor espera; y si á los Ayuntamientos, Comisiones de evaluación y Juntas periciales, que serán el principal obstáculo, porque al formar las cuentas para las cartillas procurarán elevar los gastos y disminuir los productos, lo cual nada más natural que asi sucediera, puesto que no habian de intentar perjudicarse; pero este inconveniente puede evitarse, confiriendo tan

(1) Como la creada por la ley de 17 de Julio y Real decreto de 14 de Agosto de 1895.

Crisis agrícola. 
importante misićn a una Junta en cada partido judicial, bajo la presidencia de un Diputado provincial, de un labrador y ganaderos designados por el Ayuntamiento, un Ingeniero agrónomo, y un perito agrícola, ó á falta un capataz de cultivos de Secretario; cuya Junta así compuesta podría consultar todos los datos necesarios y conocer á fondo las condiciones especiales de todos y cada uno de los pueblos del partido, y formar con equidad y acierto las nuevas Cartillas, ó examinar y rectificar las presentadas por virtud del Real decreto de II de Agosto de I887.

Para las reciamaciones de los Municipios que se consideren agraviados, una Junta provincial, compuesta del Gobernador Presidente, de dos Diputados de la Comisión provincial, del Administrador de Hacienda, del Comisario régio de Agricultura, de un Ingeniero agricola, dos peritos agrónomos y un agricultor de cada cabeza de partido judicial designado por el Ayuntamiento respectivo, funcionando como Secretario el Oficial del negociado de la estadistica Territorial.

De esta manera se evitaría el gran inconveniente antes expresado y el no menor de fallar la Delegación de Hacienda, ó la Dirección sin conocer las condiciones de cada localidad, siendo á la vez juez en causa propia. Si además se impusiera un cupo fijo á cada provincia, por lo que viene pagando en la 
actualidad, sin perjuicio de las modificaciones ulteriores que procedan, y sin que el tipo de gravamen exceda del I 2 por 100 , sería un medio eficaz para descubrir riqueza, y evitar malas calificaciones y clasificaciones.

Comisiones especiales para efectuar la clasificación de cultivos y la clasificación de fincas.

Para calificar y clasificar bien las fincas, base esencialísima de las demás operaciones, quisiéramos el valioso concurso de un personal técnico, asífacultativo como administrativo é imparcial, que ofrezca garantias, como el creado por la ley de 17 de Julio de I 895 , sobre rectificación de las cartillas evaluatorias y Real decreto de I4 de Agosto del mismo año con las disposiciones referentes á su ejecución y cumplimiento; pero como el mal apremia y es de los que con mayor premura demanda un auxilio eficaz é inmediato, el procedimien to que se ha adoptado en la provincia de Granada es demasiado costoso, y sobre todo muy lento, que si se ha de aplicar tambiéná todas las demás provincias del reino, se prolongará por muchosaños la muy ansiada, indispensable y perentoria reforma de los amillaramientos que por tanto tiempo vienen rigiendo con tan graves y manifiestos errores, escándalos y arbitrariedades que ninguno ha tratado de remediar, y atendiendo á 
que nadie conoce mejor las condiciones de cada finca rústica que los mismos que las cultivan, y los que vén uno y otro año los resultados de aquellas y los de otras inmediatas, no vacilamos el proponer que tan interesante vervicio lo lleve á cabo, bajo su más estrecha responsabilidad una Comisión municipal, compuesta del Ayuntamiento y Junta pericial ó la Comisión de evaluación donde exista y dos labradores propietarios de cada uno de los términos colindantes que designe la Corporación municipal de entre los contribuyentes de la clase primera que no pertenezcan al Ayuntamiento, Junta ó Comisión; y cuyos vocales de los pueblos limitrofes tendrán para todo lo relativo á las operaciones insinuadas, voz y voto, como los demás de la población respectiva.

Cuando corresponda calificar las fincas de alguno de los vocales de la Comisión municipal, las de sus hijos, nietos ó hermanos, no podrá tomar parte en las discusiones, $y$ el interesado se retirará del local, mientras los demás vocales efectúan la operación indicada.

A las repetidas operaciones de calificación y clasificación de fincas, se les dará la mayor publicidad por bandos y pregones y por anuncio en el Boletin Oficial de la provincia, debiendo permanecer expuestas al público por término de un més, á fin de que los vecinos $y$ 
forasteros puedan enterarse libremente de ellas y formular las reclamaciones de agravio absoluto ó comparativo que tuvieren por conveniente.

Al dia siguiente de haber espirado el plazo para las reclamaciones, se reunirá la Comisión municipal con el objeto de resolver las presentadas; debiendo comunicar su resolución á los interesados, á fin de que éstos puedan alzarse de aquella ante la Junta de partido. Lo propio se hará de los acuerdos de ésta para que los reclamantes puedan acudir à la Junta provincial, la que fallará sin ulterior recurso. Las resoluciones de las Juntas provinciales, además de comunicarlas á los interesados, se publicarán en los Boletines Oficiales de las provincias respectivas.

Todas las solicitudes, certificaciones y diligencias relativas á las mencionadas reclamaciones, serán gratuitas y se usará para ellas papel de $14{ }^{2}$ clase ó de oficio.

Reformas indispensables.

Aun cuando sea sólamente con el carácter de provisional, deben efectuarse sin la menor dilación las operiones expresadas, y como complemento de las mismas un amillaramiento breve y sencillo, como ya hemos indicado, ó un registro fiscal en todos pueblos de su riqueza rústica respectiva, á cargo de la Comisión municipal ya mencionada, 
y el exámen, aprobación y resolución de reclamaciones si las hubiese à la referida Junta provincial; todo lo cual puede efectuarse dentro del término de un año, siempre que haya voluntad para disponerlo y energía para ordenar llevarlo á cabo, pues una vez formadas las cuentas de gastos y productos de las diversas producciones agrícolas, el trabajo de verdadera importancia consiste en clasificar bien el cultivo y calidad de cada finca, cuyo propósito puede conseguirse sin necesidad de planos topográficos con extensos croquis y demás trabajos científicos, aunque no se abandone el sistema planteado, al cual, lejos de oponerse, podria servir de base, consulta y de mucha valia para la mayor facilidad de tan lentas y complicadas operaciones, con el importante y anhelado objeto de llegar en definitiva á una perecuación ó igualdad tributaria, ó por lo menos á una distribución más equitativa y aproximada á la verdad.

No es posible demorar por más tiempo un servicio tan interesantísimo y apremiante que reclaman de consuno y con insistencia imperiosa la razón y la equidad, los intereses preferentes del Tesoro y los no menos legitimos de los contribuyentes de buena fé, á fin de unificar la base de la tributación, acomodar los tipos tributarios al verdadero valor y producto de la riqueza, imponer todo 
lo que sea justo á los que tienen asignado á sus tincas la mitad ó menos de lo que les corresponde, y rebajar las cuotas á los muchos contribuyentes que pagan de más, haciendo así justicia à los agraviados, que necesitan una reparación leal y de eficacia; porque con la simple reforma de las cartillas evaluatorias se conseguirá segúramente que desaparezcan diferencias nutables, claras y manifiestas, puesto que han aumentado los gastos de cultivo y disminuido èl valor de los productos agrícolas, en particular el vino que antes se vendía á 4 y 5 pesetas el cántaro, y ahora no se logra vender ni aún á 2; pero no se evitará la escandalosa desigualdad del gravámen, pues mientras unos contribuyentes resultan muy favorecidos, otros pagan con exceso, y no puede haber verdadera equidad mientras subsista la causa primiti$\nabla a$, radical y originaria de tantos males, que no es otra que el amillaramiento actual, con sus apéndices y repartos (más injustos y más defectuosos que las cartillas), en los que no aparece el reflejo fiel y exacto de la verdadera riqueza, sino que por el contrario constituye la fuente, principio y raiz de multitud de embrollos, arbitrariedades é injusticias. 


\section{Las heladas y las sequías}

deben ser consideradas como calamidad para. obtener el perdón de la contribución

\section{Territorial.}

El reglamento sobre la contribución Te-rritorial de 30 de Septiembre de 1885, para la ejecución de la ley de 18 de Junio del: mismo año, uno de los más completos y acabados que se han publicado hasta la fecha, ha venido á llenar un vacio, una necesidad sentida en los pueblos afligidos por los perniciosos efectos de las terribles inundaciones, fuertes pedriscos, incendios, plagas ó cualquier otro desastre verdaderamente extraordinario.

Los particulares, lo mismo que los pueblos ć las provincias que por causa de una. calamidad extraordinaria hayan experimentado la pérdida de una cuarta parte, ó más. de las cosechas, pueden solicitar el perdón: de la contribución en la parte proporcional á los daños sufridos (I); es ya un derecho, aunque triste, el que aquellos pueden ejercitar en reclamación de una deuda sagrada, lo. que desde i87o se concedía como una gracia, en casos muy raros y excepcionales; pero no.

(1) Caps. VI y VII. 
sabemos la razón de no comprender igualmente todos aquellos casos en que las heladas repentinas, cual las terribles tormentas, arrebatan en breves instantes los frutos de penosos trabajos; y cuando los campos son devastados por una prolongada sequía que convierte en aridez, tristeza y desencanto, lo que antes era vegetación, lozania y esperanza.

Las aguas torrenciales que, por las catástrofes geológicas, visitan con tanta profusión algunas comarcas en determinadas épocas del año, por efecto de los cambios atmosféricos, niegan en otras las nubes la benéfica acción de las lluvias cuando son más necesarias para el desarrollo y nutrición de las plantas; originándose como consecuencia natural é inmediata de tan triste circunstancia, la pérdida en absoluto de las cosechas de cereales y frutos, la mortandad de los ganados, la ruina de muchos agricultores, y la emigración de los jornaleros, particularmente en las zonas en que la inmensa mayoria de las tierras laborables son de secano y carecen de canales de riego.

Los efectos de las heladas en los viñedos, olivares y árboles frutales son muchas veces: más funestos que los del granizo y los de las inundaciones; pues los de aquellas no se limitan á un año exclusivamente, sino que su acción destructora es de mayor alcance $y$ 
trascendencia, en particular en los viñedos é ingertos nuevos, á los que impide su desarrollo y fructificación por algunos años inmediatos sucesivos. Por lo cual, no podemos manifestar nuestra conformidad con la Circular de ro de Octubre de I86I, declarando que las heladas no podian considerarse como una calamidad extraordinaria para poder aplicar la instrucción de 20 de Diciembre de 1847 (I) y en la que, entre otros pormenores, se consigna que ala Dirección considera de muy distinta manera las pérdidas por los hielos, porque no puede ni debe apreciarse más que como un hecho natural ú ordinario de la cosecha. Es decir, como la que puede ocurrir por efecto de las excesivas lluvias (2) que haga perder parte de la recolección; por la demasiada sequia en que puede suceder lo mismo, se ha presenciado en el corriente año, ó por los continuados calores que pueden experimentarse también, y ser origen, por lo tanto de la pérdida ó disminución de la cosecha (3)).

(1) Entónces vigente; ahora sustituida y reformada por los caps. VI y VII del citado reglamento de 30 de Septiembre de 1885.

(2) Ahora comprendido este caso en el art. 88 del supradicho reglamento.

(3) Más sabia, previsora y equitativa fué la ley de Presupuestos de 30 de Junio de 1892 al autorizar al 
Claro que pueden ser, como lo han sido repetidas veces, origen de la pérdida absoluluta ó relativa de las cosechas las prolongadas sequías, ó los continuados calores, como sucedió el año 68 de dolorosa memoria, tan fatal para ambas Castillas y para otras importantes comarcas agrícolas, y como puede repetirse de diferentes ocasiones; de la propia manera que helarse las viñas y olivares y no cosechar vinos, ni aceites; así que no vemos la razon de no comprender en igual caso que el pedrisco, las heladas y las sequias; ya que sus efectos son muchas veces más destructores.

Por lo tanto, y como principio de equidad, entendemos que será conveniente establecer que las fuertes heladas y las prolongadas sequias, se consideran comprendidas en el propio caso que los pedriscos é inundaciones para los efectos del perdón de contribuciones, siempre que por tal circunstancia se justifique la pérdida de una cuarta parte por lo menos de la

Gobierno para invertir hasta la suma de 750.000 pesetas en socorrer con la rapidez posible á los pueblos que por inundaciones, heladas ó pedriscos perdieron la totalidad ó la mayor parte de sus cosechas; y que el Gobierno, con tanto acierto, haciendo uso de la autorización que le fué concedida, abrió un crédito de 200.000 pesetas á tan laudable y benético fin, por Real decreto de 26 de Julio de 1892. 
cosecha que esté pendiente de recolección, cuando aquellas ocurran.

Conveniencia de una Caja nacional de calamidades.

Desde que en mal hora fué suprimido por la ley de 23 de Febrero de 1870 , el fondo pre. visor de reserva llamado supletorio del I por Ioo que se recargaba en la contribución de inmuebles, cultivo y ganadería para atender á cubrir fallidos y á los perdones proporcionales de contribuyentes, pueblos y provincias por los siniestros de calamidades públicas, conforme á los arts. 26 y 27 de la instrucción de 20 de Diciembre de 1847 que se dictó expresamente para regularizar la inversión del insinuado fondo supletorio, haciase necesaria una ley en cada caso para conseguir perdones en la contribución, y por tanto, los expedientes respectivos debian pasar á las Cortes, para que si lo estimaban procedente, acordasen aquellos; convirtiendo en favor especial lo que debiera ser una deuda ineludible; y si bien la ley de 26 de Diciembre de 1872 (I) vino á restablecer el expresado recargo, reproducido de una manera implicita por la de 2 I de Julio de 1876 (2), y en la de 2 I del

(1) Apéndice letra $\mathrm{A}$ base $10^{\mathrm{a}}$
(2) Art. $6 .^{\circ}$ pár. $10^{\circ}$ y art. $9 .^{\circ}$ par. 5. 
propio mes de 1878 (1) se facultó expresamente al Gobierno para el abono de los perdones de contribución otorgados antes de 1872 y que debieron imputarse al recargo del I por 100 que percibió el Tesoro, no sabemos haya llegado el caso de abonar un céntimo; pues la Hacienda fundándose en que el recargo del I.por 100 que sustituyó al antiguo fondo supletorio era un recurso muy diferente, y en que estaba sujeto á las reglas es. tablecidas para los gastos del Estado, quedó aquél en su favor para cubrir las atenciones de la recaudación, los gastos de administración y comprobación, y los perdones que en casos muy extraordinarios se acordasen por una ley, y los contribuyentes y pueblos perjudicados no han logrado ver satisfechos sus legitimos deseos.

Conforme á la ley de 18 de Junio de I 885 (2) y al reglamento de 30 de Septiembre del mismo año (3), el importe de los perdones de la contribución Territorial por causa de calamidad extraordinaria, es siempre á más repartir entre los contribuyentes del distrito, de la provincia, ó de la Peninsula é islas adyacentes, segun que aquella se refiere á los particulares, al pueblo, ó á una provincia

(1) Art. $60^{\circ}$

(2) Art. 9.

(3) Art. 8\%. 
entera; cuyo sistema no puede ser de mejores resultados para la Hacienda, pero en daño de los demás contribuyentes agobiados ya bajo el peso de las cuotas propias, á un tipo de tributación sin igual en Europa.

Ya que no puedan evitarse las calamidades y desastres que son tan frecuentes en nuestro pais, es necesario crear una gran Caja nacional de calamidades, para indemnizar las pérdidas parciales ocasionadas en las fincas por las inundaciones, pedriscos, heladas, sequias, plagas, y por la mortandad epidémica en los ganados, y á fin de que desaparezca cuanto antes la notoria injusticia de cargar á los pueblos las partidas fallidas.

Para ello, conceptuamos lo más viable establecer un recargo de I por 100 sobre las cuotas del Tesoro en sustitución del repetido fondo supletorio para destinarlo al exclusivo fin indicado; y cuyo importeó recargo habrá de entregar la Hecienda por trimestres á las Diputaciones provinciales respectivas para su administración y aplicación, conforme á las prescripciones del mentado Reglamento sobre contribución Territorial (I).

(1) El recargo que proponemos supone un millón de pesetas próximamente, pues en los Presupuestos del Estado de 1895-96 se presuponen 110.000.000 de pesetas como ingreso por la contribución Territorial y Pecllaria (por Urbana 48.000.000: por Industrial y de 
Asi se evitaba lo que pocas reces se logra por oponerse los pueblos y particulares que después han de pagar forzosamente las cantidades que se perdonen á los contribuyentes perjudicados por las calamidades, y á estos se concedian facilidades para percibir algun socorro que aliviase su triste situación, haciéndola más llevadera, é imitando en este punto á Francia que ha establecido un impuesto ó recargo para el seguro de calamidades y pérdida de cosecha.

En el fondo común ó Caja riacional de calamidades se podrian admitir también todos los donativos que con tan benéfico y elevado fin tenga á bien destinar la caridad; ese ange! del bien, ese bálsamo sublime tan eficaz como reparador para prestar un alivio al necesitado, un socorro al desvalido y un gran consuelo á la desgracia; pues sabido es que en España siempre se acudió á mitigar en lo posible el infortunio, con más prontitud y desprendimiento que la ley.

Comercio 45.000.000); y cuyo recargo, para no menos cabar la fortuna pública, pudiera aumentarse sobre el tipo de gravamen de toda la riqueza contributiva, para socorrerá los contribuyentes que tengan que sufrir los tristes efectos de las calanidades.

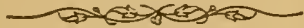





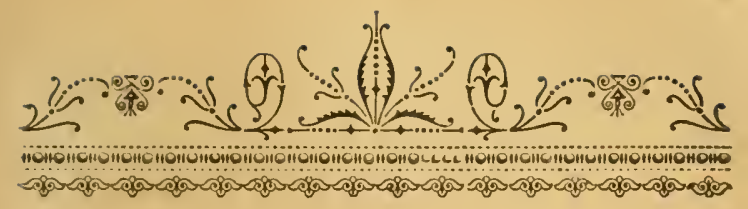

\section{CAPITULO VII.}

Asociación de las clases productoras.

1. Necesidad de una bien entendida asociación agraria.

2. La vida del labrador. $-E l$ vinicultor.

3. El Partido Nacional Agricola.-Quiénes deben constituirle.-Fines elevados del mismo.

4. Conveniencia de su organización inmediata para obtener las reformas que tanto interesan á las fuerzas productoras.

5. Al gran partido corresponde designar los que hayan de representarle en el Parlamento.

El hombre, ese sér superior á todos los demás séres que pueblan la tierra, desde que tuvo idea de sí mismo, impulsado por el hermoso sentimiento de la fraternidad y el de mútua simpatia, y por ser además sociable por naturaleza, instinto y conveniencia,

Crisis agrícola. 
reconoció la necesidad imperiosa de reciproco auxilio, y por tanto la de asociarse á sus. semejantes, á los que vivió unido en comunidad de ideas é intereses, para obtener los. beneficios de que aislado carecia (1).

La asociación es indispensable en la especie humana para su mayor desarrollo y progreso, lo fué desde que ésta apareció sobre la tierra, y lo será mientras subsista, puesto que aquélla forma parte del órden universal y es preceptiva en el terreno de la moral, fundamento sólido sobre el que se apoyay descansa la paz interna producida por la cordialidad y harmonia en las relaciones exteriores, y necesaria además para que los bienes materiales que reporten de la misma resulten útiles y agradables.

(1) Pues no admitimos la opinión de Epicúreo y Lucrecio al afirmar que hubo una época durante la cual los hombres vivieron en estado completamente salvaje, sin idea de la religión y de la familia, y sin noticia alguna del deber y del derecho, cuya teoría han negado en absoluto, sosteniendo la de estado de sociedad, como inherente al estado natural del hombre que le impele á congregarse los esclarecidos filósofos Platón, (Repúbl. lib. 2), Aristóteles (Polit. lib. 1), Cicerón (De Repúbl. lib. 1), y otros, cuya doctrina se halla consignada en los Sagrados textos; y porque al crear Dios la mujer que dió al hombre por compañera quedó constituida la verdadera familia; primera y única sociedad que existió durante mucho tiempo. 
El hombre por si solo, aunque dotado de cuantiosos elementos, no puede acometer empresas de importancia si se abandona á sus esfuerzos individuales, pero asociado á otros constituyendo una colectividad poderosa y ordenada, se multiplican extraordinariamente sus medios de acción que le permiten llevar á feliz término las empresas más gigantescas, las obras más portentosas, los proyectos más difíciles y arriesgados.

Sin la asociación no se hubieran llevado á efecto las grandiosas obras realizadas con tan asombroso éxito en las edades antigua, media y moderna, ni se hallarian en el estado de adelanto á que vemos hoy que han llegado las ciencias, las artes y las industrias. Sin la asociación, en fin, no hubiera sido posible la familia, el pueblo y la ciudad; tampoco el Municipio, la Provincia ni el Estado; ni la gran sociedad de todos los hombres del universo, que constituye la humanidad.

Aún cuando no fuera por el espíritu elevado, noble y generoso de prestar el hombre su inteligencia y apoyo para cumplir en la tierra una misión bien grata y placentera, cual es la de ser útil á sus semejantes, conforme lo requieran las necesidades de los mismos, y á los medios, aptitudes y facultades que para atenderlas posea, contribuyendo al propio tiempo al bienestar publico, á esa tendencia hermosa, idea sublime, 
aspiración honrosa, cualidad altamente plausible que tanto enaltene á todo el que la practica, debe asociarse á sus congéneres ante la necesidad que le impele á la defensa constante de sus intereses y derechos, y á que tanto le obligan las circunstancias actuales, si no ha de presenciar impasible y contribuir con su indiferencia estóica à labrar su propia ruina y la de su familia, ó siquiera por el instinto de conservación del que los animales nos dán repetidos y provechosos ejemplos, dignos, en verdad, de encomio y de imitación por parte del hombre.

¿No vemos á los inocentes pajaritos que cuando más alegres $\mathrm{y}$ bulliciosos se hallan en las regiones aéreas, llenando los espacios con sus gorgeos y trinos sonoros al divisar al azor, gavilán ó á cualquier otra ave de rapiña, por diseminados y aún divididos que se encuentren, se estrechan, cesan sus discordias y se unen á porfía para afrontar mejor el peligro y vencer á su enemigo? ¿No hacen lo propio las mansas ovejas, los caballos y hasta las vacas y toros a pesar de su fuerza y bravura al verse acometidos por el lobo ó el oso? Pues qué ¿no imitan tan hermoso ejemplo las gallinas cuando se vén sorprendidas por el zorro astuto ó la garduña artera, que todas se unen y defienden y como sobrecogidas de terror y espanto impetran auxilio y protección con sus cacareos estridentes 
y lastimeros? $Y$ ¿no le siguen también las golondrinas, vencejos, (I) y demás aves que nos visitan anualmente, las cuales vienen unidas, y en la propia forma regresan á sus respectivos paises? ¿Y las grullas cuando caminan en correcta formación figurando un ángulo agudo para prevenirse mejor contra lus ataques del enemigo?

Las tribus del Asia y Africa que hoy todavia carecen de cultura é instrucción necesaria ¿no se unen también como un solo hombre, se presentan iracundos y hacen titánicos esfuerzos para la defensa de sus territorios, derechos é intereses respectivos?

Pues si vemos que los animales se unen y defienden con tanta solicitud y bizarria ante el enemigo común, sólo por el instinto de conservación, cuya loable conducta imitan los pueblos incuitos, con mucha mayor razón las personas civilizadas é instruidas, de prudencia y posición social, deben imitar tan

(1) Los vencejos que han sido los últimos en llegar, son los primeros que se deciden por la emigración, vinieron por Hayo, hicieron una sola cria, y parten á últimos de Julio ó á primeros de Agosto. Ya desde el 10 al 20 de Julio en las noches calurosas, se han reunido en grandes asambleas como si debieran concertar'se sobre un suceso de los más interesantes de su vida. (Joigneaux en su obra Animales uitiles y dañinos á la agricultura). 
bello ejemplo; no ya por instinto, sino por una persecución sincera y por un convencimiento intimo para cumplir los fines peculiares de la asociación y para otros no menos importantes que deben llenar en la sociedad, desde la altura á que les conduce su propia superioridad é ilustración; para los diversos medios y propósitos razonables de la vida; para ejercitar los nobilísimos actos de caridad y misericordia, y hasta para cumplir la triste y piadosa misión de enterrar á los muertos.

Necesidad de una bien entendida asociación agraria.

Pero si la asociación es indispensable en todas las clases sociales para los diferentes fines particulares de la vida humana, lo es mucho más à la clase agricola, por ser la más agobiada de tributos, la mas desatendida por parte de los gobernantes y la que menos protección encuentra á sus justificadas pretensiones, á pesar de ser la más laboriosa, la más sensata, la más sufrida, y la que más contribuye al sostenimiento de los servicios públicos.

¿Cómo se explica tamaña anomalía? ¿En qué consiste tan injustificado desdén? ¿Por qué no se atiende á tan desheredada clase? ¿Qué causa es la que motiva esa falta tan 
notoria de equidad y protección para con los agricultores?

En nuestro concepto, no es otra que su misma apatia, ni consiste más que en su inercia y abandono; en su falta de unión.

Pensar de otro modo, sería incurrir en un error lamentable, y como sabido es que el error oscurece la razón, otra idea ó hipótesis diferente pudiera conducirnos al absürdo de atribuir a causas iguales resultados diametralmente opuestos.

Es preciso, pues, que á la apatia y negligencia que tanto impera en los agricultores (que no vemos exista en ninguna otra clase social), á su excepticismo y á su poca unión, obedecen principalmente los males que lamentamos.

Un reloj cuando sus numerosas y complicadas piezas se hallan separadas unas de otras sin órden ni enlace alguno, no puede funcionary menos con regularidad, y para que mida al tiempo con la mayor exactitud, es necesario unir todas y cada una de aqueHas proporcionada y ordenadamente.

Un ejército por fuerte $y$ numeroso que sea y que tenga á su disposición poderosos elementos de combate, si en vez de marchar unido y con la mayor fé y denuedo á los campos del honor, é imprimir á todas sus operaciones un bien combinado y madurado proyecto y una acción simultánea para 
conquistar bien en breve, ó ya palmo á palmo el laurel de la victoria, se dispersa en pequeñas fracciones sin plan alguno determinado. y carece de instrucción, uniformidad, disciplina y entusiasmo por la causa que defiende, por muy santa que ésta sea y en vindicación de una ofensa ó ultraje inferido á la pátria querida, se expone á ser víctima del enemigo, ó por lo menos á servirle de juguete en sus planes ó propósitos más ó menos ambicionados.

Pues una cosa idéntica sucede à las fuerzas productoras del pais; diseminadas como. lo están, sin organización alguna por falta de un bien entendido espíritu de asociación. nadie las atiende, sus justas quejas y constantes reclamaciones aunque parecidas á las del náufrago que impetra socorro y protección para librarse de una muerte que vé ya muy próxima, son lamentos vanos que se pierden en el vacio de la indiferencia, como se pierde el eco de una débil y tímida voz en desierto dilatado.

Otra cosa muy diferente sería y otros resultados más satisfactorios y lisonjeros habrian de obtenerse, sin duda alguna, si aquéllas estuvieren unidas y bien organizadas, de cuya circunstancia tan esencial no se cuidan ni se preocupan á pesar de los muchos desengaños recibidos y de los perjuicios y vejaciones que sufren; $y$ mientras continúen. 
en tan anómalo y censurable estado, se agravará cada dia más el mal de que se lamen$\tan$. Es necesario que se persuadan de una vez que unidas verán realizadas sus legitimas aspiraciones; pero sin una estrecha y bien entendida asociación, serán siempre como las hojas secas desprendidas del árbol, las cuales quedan á la voluntad y capricho del viento.

Con muchisima más autoridad y elocuencia que nosotros pudiéramos hacerlo, se expresa el inmortal Lamennais (I) en las siguientes sublimes palabras:

«Cuando un árbol está solo, bátenle los vientos y le arrebatan sus hojas y sus ramas, y en vez de elevarse en el espacio, la fuerza del huracán le inclina, como si buscase la tierra. Cuando una planta está sola, sin abrigo que la defienda de los ardientes rayos del sol, se marchita; se seca y muere. Cuando un hombre está solo, el viento del poder le dobla hácia el suelo, y el ánsia de la codicia de los grandes de la tierra, absorve la sávia que le alimenta. No seas como el árbol, ni como la planta que están sólos; más unios los unos á los otros y servios mútuamente de apoyo y de abrigo. En tanto que vivais desunidos y que cada cual no mire sinó por

(1) Erı su inspirada é interesante obra Palabras de un creyente. 
si, pesaran sobre vosotros, los sufrimientos, las desdichas y todo linaje de opresión. ¿Hay cosa más débil que el gorrión, ni más indefensa que la golondrina? y no obstante, cuando el ave de rapiña aparece, los gorriones y las golondrinas logran ahuyentarla, reuniéndose en derredor suyo y persiguiendo todos á una. Tomad ejemplo del gorrión y de la golondrina. A aquel que se separa de los suyos, siguele el temor cuando anda, siéntase junto á él cuando descansa, y ni aún durante el sueño le abandona. Dios no ha creado ni pequeños ni grandes, ni señores ni esclavos, ni reyes ni súbditos; sino que á todos los hombres los ha hecho iguales».

¡Hermosa y profunda filosofía inspirada en el precepto sacrosanto de amar entrañablemente al prójimo, consolar al triste, alentar al débil, fortalecer al tibio, dar la mano al caido! Palabras elocuentes y expresivas impregnadas del aroma purisimo de la caridad, y que no deben olvidar jamás los agricultores, pues parace que fueron escritas exclusivamente con el objeto de alentarles á un verdadero espiritu de asociación.

aLas asociaciones agrarias han de proporcionar beneficios inmensos para la economia de la producción. No sólo constituyen el elemento más propio para el estudio práctico de todas las cuestiones económicas, sino que 
en compras y arrastres pueden beneficiar las considerables rebajas de toda operación al por mayor, aprovechar las tarifas especiales de vagón entero, comprar maquinarias, abonos y semillas, hacer los contratos de seguro sin agentes intermediarios, tener labatorios para análisis de productos, abonos y tierras, y hasta organizar al por mayor la venta de de su propia producción, como los granjers de los Estados Unidos que colocan directamente sus cosechas en los principales mercados de América y Europa (1)".

En eîecto, las asociaciones agrarias reportan ventajas inmensas para la economia de la producción y también para otros fines, todos á cual más importantes, relacionados con la Administración pública, de cuyas inapreciables ventajas carecen los agricultores españoles por no imitar el ejemplo que vemos en los de otras naciones.

Prescindimos, para no ser difusos, de los que por la historia nos ofrecen las primeras asociaciones orientales; los plebeyos para defender la primera ley agraria; las Cruzadas, vastas asociaciones que además de libertar á Europa de la invasión de los turcos, contribuyeron poderosamente á debilitar el poder de los señores feudales y á descubrir nuevos horizontes para la geografla, la historia, la

(i) Sánchez de Toca en su obra La Crisis agraria europea ya citada. 
agricultura, el comencio y la industria con sus valiosos datos, sueltas producciones y nuevos artículos de comercio: las asociaciones populares que crearon los Comunes ó Municipios, los cuales anonadaron al reudalismo y realizaron muchos hechos gloriosos de engrandecimiento y de conquista, y como prescindimos también de otros muchos ejemplos, incluso los que hoy vemos en los Estados más poderosos y civilizados de la tierra al formar entre si estrecha alianza, que la índole de nuestra obra no nos permite detallar, y porque sus medios y sus fines difieren del objeto que nos proponernos: por lo tanto, sólo nos concretamos á indicar brevemente algunos casos de asociación agraria en diversas naciones cultas.

En Francia, nación ilustrada y poderosa, por efecto de un práctico y bien dirigido espíritu de asociación, existe la Sociedad general de Agricultores con un Sindicato Central en Paris, 177 I sindicatos régionales, más de 100 Cajas ruraies de crédito y 600 sociedades de consumo. Esas asociaciones fuertes, vigoro-. sas y bien organizadas disponen de un nucleo de Diputados del que es digno Jefe Mr. Meline (1) que ubliga á los Poderes públicos á

(1) Al que se deben las disposiciones gubernamentales dictadas en aquel pais en faror de sus productos, logrando cerrar casi por completo sus mercados á nuestros vinos. 
atender sus legitimas pretensiones y algunas veces decide la victoria ó derrota de los Gobiernos. Hermoso ejemplo digno de ser imitado en España y del que tan buenos resultados pudieran esperarse en beneficio de las desatendidas clases productoras.

Los alemanes con sus Bauernvereine las numerosas cajas agricolas Raiffeisen, Schulze Delitsch y otras perfectamente organizadas y sostenidas por importantes sociedades mútuas, en las que modestos agricultores figuran entre los propietarios acaudalados, constituyendo una basta sociedad rural que funciona con el más favorable éxito en los diversos ramos de acción que la misma abraza, con independencia absoluta de la Administración pública. Además cuenta con buen número de representantes en el Reichstag para la defensa constante de los intereses y derechos privativos de la sociedad.

En Austria-Hungria, debido al impulso poderoso de sus bien organizadas ligas agrarias, han conseguido éstas suprimir los numerosos tributos especiales que pesaban sobre la agricultura y disfrutar de más elevada consideración social. Hoy disponen de multitud de asociaciones, y provechosas é instructivas revistas agricolas al alcance de las fortunas más modestas.

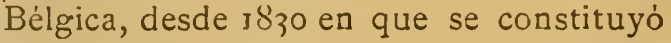
como Estado independiente, ha progresado 
con asombrosa rapidez hasta el extremo de ser en la actualidad el pais mejor cultivado y el de mayores rendimientos del globo terráqueo que habitamos. Cuenta con numerosas ascciaciones oficiales y particulares; revistas y publicaciones diarias y semanales para la propaganda de conocimientos útiles y de cuanto interesa á los afiliados; y en la Administración pública tienen buena representación las clases productoras.

Italia, con su bien organizada é importante Confederación de propietarios que facilita la venta de sus frutos en las más ventajosas condiciones posibles para el productor, particularmente en los vinos; á cuyo ramo $\tan$ interesante de la riqueza pública en aquella peninsula meridional, dedica atención preferente y asidua.

Los irlandeses, por medio de sus ligas agrarias y de una constancia admirable, no obstante el poder inmenso del Gobierno británico y los escasos elementos de que disponen los agricultores, como colonos que son en su mayor parte explotados por los opulentos propietarios, han conseguido reformas ventajosas para los asociados de que antes carecian.

Suiza acaba de obtener un señalado triunfo comercial con Francia, debido principalmente á la unión de las clases productoras. 
En los Estados Unidos es donde el espiritu de asociación ha alcanzado las mayores proporciones, con sus potentes sociedades rurales, organizadas en todo aquel vasto territorio, particularmente en la región del Missouri y en Nueva California, habiendo logrado rebajas considerables en los precios de transportes para toda clase de productos é instrumentos agrícolas, tanto en las vias terrestres como en las fluviales y maritimas, que les permiten hacer grandes exportacio nes de los mismos á todas partes del mundo.

Solamente los sufridos agricultores espanoles permanecen en la mayor inercia $y$ abandono, sin iniciativa alguna para mejorar la triste situación en que les ha colocado su propio excepticismo; siendo asi, que en ningún otro pais civilizado necesitan las clases agrícolas más que en el nuestro del poderoso vinculo de la asociación, si han de ser debidamente atendidas, disfrutar de mayor consideración social y obtener mejor recompensa á la azarosa vida que llevan constantemente derramando el sudor de su rostro en el cultivo de la tierra.

\section{La vida del labrador.}

No vamos á describir ningún tipo bíblico, tampoco mitológico, ni à pintar un cuadro con sombrios colores, ó de pura fantasía, sino á bosquejar breve y sucintamente la 
vida y situación de nuestros modestos labradores.

El cultivador agricola, el que se dedica con solicito afán á la noble, azarosa y utilísima ocupación de labrar los campos, facilitando al propio tiempo medios de subsistencia á la humanidad, desde que abre en la tierra los primeros surcos y deposita despues en ellos la semilla hasta tanto que coloca la cosecha en la panera, son muchos los trabajos y privaciones que sufre.

Desde que el crepúsculo matutino aparece en lontananza, y el dia anuncia sus albores (y muchas veces antes) ya sale aquel de su casa, con sus ganados, aperos ó herramientas, provisto únicamente de las frugales viandas que lleva al campo, y unas toscas ropas, que cubren su cuerpo, lo mismo en los rigores del invierno cuando las fuertes heladas dejan su blanca y cristalina alfombra sobre los tejados y azoteas de los edificios, los árboles, las plantas y sobre la misma tierra que ha de labrar y el frio es casi tan intenso y penetrante como el de las regiones polares, que en los rigores del verano, cuando el calor es el de un sol tropical abrasador, y ya el cielo aparezca azulado y sereno, como si está nublado ó amenaza tempestad. No va provisto de impermeables ni de finos abrigos de pieles para precaverse de las lluvias y frios, porque su modesta posición no le permite 
tales comodidades, ni tampoco puede disponer de edificios donde refugiarse durante las tempestades, pues los pocos que hay en el campo suelen éstar muy diseminados. Trabaja à la intemperie cuanto puede, y sufre con su cuerpo el frio, el calor, el aire y el agua hasta tanto que las tinieblas de la noche le obligan á regresar á su hogar, en el cual no puede hallar la satisfación y alegria que en otros tiempos más favorables para el agricultor, ni aun descansar con tranquilidad, porque tiene que cuidarse de alimentarlos durante la noche para poder proseguir al día siguiente sus rudas tareas.

Cuando se aproxima la época della recolección, en que el sol se eleva majestuosamente sobre el horizonte, luciendo su disco de fuego, y sus rayos caen casi perpendiculares sobre la tierra, los termómetros marcan más de 30 grados à la sombra, la atmósfera es sofocante $y$ enrarecida, y muchas personas de posición social marchan á respirar la fresca y salulifera brisa de los mares, ó á contemplar las crestas graníticas de los Pirineos, ó las perpétuas nieves de los Alpes; otras á disfrutar de la suave temperatura y delicioso clima de nuestras provincias del Norte para. entregarse durante el dia á solaces giras. campestres, unas veces por valles pintorescos, engalanados por una vegetación exuberante, otras por elevadas montañas, cubiertas

Crisis agrícola. 
de frescos y variados boscajes y que dominan panoramas de una amenidad encantadora; por la noche recrearse en los cómodos salones de elegantes hoteles y descansar después en lujosos y mullidos lechos que les brindan á un asiático reposo entre los agradables y perdidos ecos de sonoras notas musicales; entónces al labrador le esperan mayores sacrificios y trabajos: es precisamente cuando tiene que imponerse mayor fuerza de voluntad para recoger el grano que ha de ser convertido en harina y después en pan, con el que han de alimentarse los hombres, y también los demás cereales que tienen que servir asimismo para alimento de los ganados; é imitando á la hormiga laboriosa se consagra á tan útiles faenas sin casi descanso alguno, porque sabe que el menor descuido, una tempestad ó un temporal de continuadas lluvias puede ocasionarle la pérdida total ó parcial de la cosecha ó al menos retrasar considerablemente tan costosas operaciones, asi que la necesidad les obliga á levantarse á las doce ó la una de la noche, ora si la opaca luna derrama ténue y melancólica luz sobre la tierra, ya si el horizonte aparece claro y sereno, como si está oscuro y tempestuoso, parte de su era con el carro y ganado para dirigirse fuera de carreteras y caminos, tan pronto por sitios llanos, como por los más escabrosos y accidentados, con grave riesgo 
de su vida y la de sus ganados do se hallan hacinadas en pequeñas morenas ó montones las doradas mieses que la hoz del segador dejó tendidas por el rastrojo, para transportarlas á la era y preparar la parva en las pri. meras horas de la mañana con los viajes efectuados durante la noche, y á fuer de vueltas con el trillo en una y otra dirección, las tornas y retornas necesarias, cuyas operaciones tiene que practicar cuando más abrasan los rayos caniculares y la tierra herida por un sol parecido al de la zona tórrida se halla calcinada, como el piso de un horno, á fin de a parvar ó recoger à la caida de la tarde; tomar después un frugal alimento, descansar vestido y al lado de sus ganados dos ó tres horas, para reponer sus agotadas fuerzas y continuar las penosas faenas del dia anterior.

Pues bien, tantas privaciones y penalidades, tan continuada série de trabajos que se enlazan y suceden unos á otros, como el dia á la noche y la noche al dia las sufren los labradorescon una resignación pasmosa (de la propia manera que los crecidos y desiguales tributosque lesabruman) sin proferir el más pequeño lamento, la mas leve queja, entonando algunas veces las más sencillas y alegres canciones populares (I); pues únicamente ansian

(1) Por más que en determinadas ocasiones cuando el español canta... lo hace por sobrellevar mejor la 
terminar con salud las rudas tareas de recolección, aun cuando se queden sin un solo grano, como á algunos los sucede, que después de aventado y bien limpio pagan desde la era el trigo que recibieron á préstamo pará la siembra, ó dinero á cuenta de aquel cereal para gastos de cultivo y para las diversas obligaciones de su casa y familia; al guarda del campo, carretero, herrero, veterinario las igualas del médico y farmacéutico y hasta los derechos de estola y pié de altar, deven: gados por el párroco durante el año (2) con lo cual muchos labradores se dan por conformes y satisfechos, por más que se queden so. lamente con la media fanega en una mano y el rasero en la otra, y para volver á sembrar tengan que buscar trigo á préstamo con tres ó cuatro celemines de interés en cada fanega, con el objeto de repetir en el nuevo año agricola sus pesadas y afanosas tareas, pues saben que es más triste aún cuando despues de haber derramado el sudor de su frente durante dos años consecutivos para remover una y otra vez la tierra, limpiarla de malas yerbas,

situación en que le han colocado las circunstancias y al recuerdo de la siguiente sátira: Al mal tiempo buena cara, y tambien: Por disimular penas vivo cantandoque sinó moriría considerando.

(1) Como acostumbran en algunas poblaciones rurales. 
sembrar y cuidar la semilla, y ya en la primavera un azulado cielo permite al astro rey de nuestro sistema planetario dirigir su luz radiante y calor vivificador para metamorfosear la naturaleza y que ésta ostente su sin igual belleza, que infinidad de pajaritos pueblen los espacios y todo en el campo sea vida, vegetación y alegria para expansión y recreo del hombre, que entónces una prolongada sequia reduzca considerabiemente la cosecha presentada, ó bien una fuerte escarcha matinal, marchite la tierna flor de las legumbres, hortalizas, frutales y viñedo y ocasione la pérdida de sus frutos, con los cuales se proponia hacer frente à sus múltiples necesidades; pero todavia es mucho más doloroso, cuando ya próximo á percibir el premio ó recompensa de incesantes afanes y trabajos por estar los frutos en sazón, se dispone á recogerlos, y al comenzar sus tareas, el horizonte se cubre de nubes densas y cenicientas que oscurecen el astro del dia, sin que casi se vea más claridad que la que surge de las ráfagas de la luz eléctrica producida por el relámpago; el trueno deja oir su ronco vibrar, la nube imponente con sus fuertes y fatidicos crespones avanzan ya lenta, ya apresuradamente con un ruido sordo, muy particular que semeja algo al que produce una locomotora á larga distancia, y que el labrador distingue por triste experiencia, y sin 
que tenga á su disposición dique alguno que la pueda contener en su acción devastadora, ni tampoco un pararrayos que le guarezca de los terribles efectos de una descarga eléctrica; los relámpagos se suceden unos á otros casi sin intermisión; los truenos cada vez más estridentes y continuos que hacen temblar al labrador; los pájaros cesan sus melodiosas canciones, unos se anonadan, y otros huyen despavoridos; los ganados se estremecen y ni los más dóciles obedecen la voz del amo ó la del gañan que los manda; las plantas se inclinan hácia el suelo, y el firmamento parece que se conmueve; ya la tempestad arrecia y la tenebrosa nube empieza á descargar granizo de crecido tamaño y con tal abundancia, que en breves momentos queda cubierta la tierra por una dilatada blanca sábana destrucctora, á manera de sudario sobre los frutos que yacen tendidos y desordenados por el suelo; trocándose en desolación y ruina, lo que antes era vida y lozania, y constituía uno de los mayores encantos, y una de las más halagüeñas y legitimas esparanzas del labrador, quedándole abatido y con el corazón contristado y lleno de amargura.

Esto es evidente, es la verdad pura, sin la menor exageración; un boceto exacto tomado del natural. Todo lo demás que se atribuye á los labradores de una calma dulce y una 
felicidad consumada, no son más que imaginaciones recreativas y relaciones fantásticas tomadas de algun libro, pero que se apartan mucho de la realidad. Es necesario pasar por tal situación, ó tocarla muy de cerca para cerciorarse de los afanes, vicisitudes y sufrimientos del labrador (1).

No puede haber calma donde existe un contínuo y justificado temor, ni felicidad donde el dolor es latente y profundo. La calma y felicidad que algunos escritores los atribuyen y parece que en efecto disfrutan en diversas ocasiones, no son más que aparentes, pues en su condición y manera de ser se resignan con su suerte, tan poco propicia, contra la que no claman, ni desesperan; si un año es de mala cosecha, esperan obtenerla buena al siguiente, ó siquiera algo mejor que les remunere el trabajo, lo cual pocas veces sucede, porque aun en el caso de que

(1) Pero no del labrador acaudalado, porque de esta clase hay muy posos en España, (y los que disfrutan pingües riquezas no las habrán adquirido seguramente con los rendimientos de la labrazan, pues no se sabe de ninguno que se haya hecho rico solo por ser labrador), sinó del labrador de modesta posición, conı lo son los que constituyen la inmensa mayoría de nuestros labradores; como asimismo del colono, y tambien del bracero ayrícola. 
les resulte algun pequeño sobrante y lo vendan cuando lo deseen ó necesiten (ya que en esta parte tengan la ventaja de que el vinicultor carece) la depreciación á los frutos de la tierra es tan considerable desde hace algunos años, que no recompensa los penosos trabajos sufridos, pagos de contribuciones, gastos de labores, abonos y semillas, reposición de ganados ya decaidos y extenuados por el trabajo y una alimentación deficiente; carros, arados y demás aperos ya inservibles por el continuado uso de los mismos; y para atender por ultimo à los gastos del presupuesto doméstico, que aunque bien meditado y conteniendo las mayores economías, las cuales obligan al jefe de la familia, asi como también á su mujer y á sus hijos, á vivir dentro de un limite muy reducido, en la mayor estrechez y con todo género de privaciones en aquel hogar santificado por la resignación y el trabajo, resulta por fin un déficit que, si bien insignificante, es ya lo suficiente para turbar su tranquilidad y reposo, y para agravar más su situación, porque demasiado sabe que le ha de conducir de una manera lenta y progresiva á su completa ruina.

Aun asi, en tan triste y lamentable situación, é imitando al pacientísimo Job, continúa dando ejemplo sublime de constancia, abnegación, sufrimiento y trabajo, sin embargo de que tambien sabe que del Gobierno no 
puede esperar la condonación, ni siquiera demora para el pago de tributos (I).

Hora es ya de que se mejore la suerte del sufrido labrador; del que sin disfrutar de paseos, policia, alumbrado y otras comodidades está obligado á la recomposición de caminos vecinales; facilita alojamientos y bagajes; entrega sus hijos para la defensa de la pátria y paga además para que el Estado atienda al sostenimiento de aquellos y al de los diferentes servicios públicos.

\section{El vinicultor.}

No menos azarosa que la del labrador es la vida del cosechero de vinos.

(1) A todos nos consta que cuando el terrible ciclón del 15 de Septiembre de 1893 de tan tristes recuerdo para muchos pueblos de ambas Castillas y algunos de Esstremadura, el Gobierno concedió muy insignificantes recursos en relación a los inmensos daños; pero ¿llegó algo á poder de los labradóres?

Los Ayuntamientos a pesar de haber instruido en tiempo y forma los oportunos expedientes solicitando condona ción de la contribución territorial, no sabemos que á ningun contribuyente se le haya perdonado su respectiva cuota, ni admitido siquiera la menor demora para efectuar el pago.

¡Pobre agricultor: después de perder su hacienda y su cosecha, tener que pagar contribuciones por productos que no ha recogido! 
No es ya solamente que una helada de primavera y los demás fenómenos meteorológicos, causen daños en el viñedo de muy difícil reparación, como tambien las diferentes enfermedades criptogámicas y que los medios adoptados para combatir estas sean costosos y muchas veces ineficaces, sino que las circunstancias porque atraviesa en la actualidad tan importante ramo de nuestra producción nacional, ya no pueden ser más. criticas, anómalas y excepcionales.

El cultivo de la vid también requiere continuos afanes y trabajos, en el cual se sostienen algunos millones de obreros durante los meses del invierno y primavera; y los viticultores darian seguramente mayor número de jornales y á más elevado precio, si tuvieran salida sus productos a precios remuneradores; pero desgraciadamente su situación no puede ser ya más triste y angustiosa y hasta para la venta de los vinos tienen que pasar por unas verdaderas horcas caudinas.

La recolección de la uva es en algunas localidades más costosa y molesta que la de cereales, si bien suele ser bastante más breve, ventaja no despreciable, pues si la vendimia durase tanto como el verano, no habria propietarios ni obreros que la resistieran; pero así como el labrador no tiene casi que ocuparse de los granos una vez que se hallan en la panera ó almacenes, no le sucede lo mismo 
al vinicultor, porque desde ántes, durante y después de la vendimia tiene que cuidarse del lavado y preparación de lagares, prensas, to. neles etc., y además de todo lo concerniente à la elaboración y conservación de los vinos (lo cual exije precauciones y conocimientos especiales), puesto que son pocos los viticultores que venden sus productos en uva ó mosto, unos por falta de compradores y otros por esperar mejores precios ó porque no se deterioren los envases, sise quedan vacios, de lo cual resulta que el viticultor tiene que ser tambien forzosamente vinicultor, pero no rutinario y apático, sinó inteligente y cuidadoso, si ha de obtener unas clases aceptables y mejor venta á las mismas, ya que no tenga la ventaja del labrador; pues éste es sabido que para vender sus frutos no precisa ser fabricante de harinas ni tampoco panadero.

Más todas esas molestias y cuidados les llevan los cosecheros con buena voluntad; pero cuando empieza el mayor sufrimiento, el verdadero calvario para el vinicultor es al dar principio á la venta de sus productos.

Tienen que resignarse á expender el vino por litros, medios litros, molestarse muchas veces. para vender, y después no cobrar; sufrir las exigencias, caprichos é intemperancias de algunos compradores; cuyas exigencias, desprecios y aún abusos suelen ser mayores á 
medida que las existencias son considerables, los precios muy reducidos, y las necesidades de los vendedores más apremiantes.

En algunas localidades pequeñas, no obstante hallarse expendiendo siete ú ocho cosecheros á la vez, otros tienen que hacer lo mismo, porque se aproxima la vendimia, todos tienen los envases llenos y no saben donde colocar la nueva cosecha, y á pesar del poco despacho y del precio tan bajo del vino, como el de cuatro, tres y aún dos reales el cántaro de 16 litros, le bajan ó reducen todavía más los nuevos vendedores, ante la necesidad perentoria de desocupar los envases y no verse en el duro trance de tener que gastar para tirar ó derramar fuera de la bodega (que suele hallarse al lado de la de sus vecinos), el vino que no han logrado vender á ningún precio, ni caro ni barato; viniendo á constituir casi en campo de Agramante lo que debiera ser estrecha alianza, verdadera fraternidad, unión, harmonia, defensa y protección mútua.

Triste condición, es en verdad, la del cosechero que tiene que pasar, tantas molestias, sinsabores y sufrimientos ante el deseo natural y legitimo, y muchas veces ante la necesidad imperiosa de expender sus frutos, obtenidos á costa de muchos gastos y trabajos, para no ser después debidamente remunerados. 
El viticultor, no sólamente no puede ya pagar mayor jornal, como desearia, al triste bracero para que á costa del sudor de su rostro gane el pan cuotidiano para sí, su mujer y sus hijos, sinó que unas veces por la depreciación de sus productcs y otras por la nula demanda á los mismos, se vé en el caso muy sensible y doloroso de tener que dejar sincultivar sus viñedos; por locual vemos que la riqueza viticola se aniquila, se destruye y se extingue de dia en dia, como luz que se apaga por falta de combustible que le alimente.

Préstase á muy tristes reflexiones que á pesar de la critica y angustiosa situación porque han pasado y atraviesan los vinicultores, sin poder dar salida à sus productos, ni aún á precios súmamente reducidos, $y$ en espera de una cosecha abundante ya presen. tada, sin envases para recogerla, que antes de cerrarse las Córtes no haya habido tiempo material para dar una solución que permitiese mejorar aunque sólo fuese en una pequeña parte la agonizante riqueza vinicola; ni se haya pensado tampoco lo que vá á ser de tantos millones de infelices trabajadores el dia que carezcan por completo de jornal en el cultivo de las viñas. Apena el ánimo más sereno, y la voluntad más entusiasta decae ante tanto y tanto desengaño.

El labrador tiene siquiera facilidad de vender sus cereales cuando lo desee, aunque 
los precios de los mismos no sean remuneradures, pero el viticultor, ai aún con pérdidas considerables puede vender sus productos, por más que necesite dinero para cultivar las viñas, pago de contribuciones y atender álas apremiantes necesidades de su casa y familia, sino que tiene que apurar el cáliz de la amargura, y después de lo mucho que le ha costado el producir el vino, como en ocasiones no hay quien lo compre ni aúná cinco céntimos de peseta el cántaro (ó sea el Irabajo material de medirlo y extraerlo de la bodega), de clases potables y buenas, se vé precisado á empeñarse y gastar de nuevo para efectuar la sensible operación de arrojarlo á la calle; todo lo cual aún cuando á algunos les parezca una paradoja, es desgraciadamente un hecho cierto y doloroso, una verdad triste y palmaria; es el colmo del sufrimiento, el verdadero martirio del vinicultor, cuya situación es insostenible, angustiosa y alarmante en extremo.

Urge, pues, que el Gobierno aplique los remedios conducentes (I), á evitar tan graves males, si no quiere que en breve desaparezca por completo una rama tan interesantísima de nuestra riqueza pública.

(1) En la Parte 2. ${ }^{a}$, cap. I; detallamos los que nos parecen más factibles y de verdadera eficacia; tanto los que corresponde aplicar al Estado como á los particulares. 


\section{El Partido Nacional Agrícola.}

Reconocida como de necesidad imperiosa una bien entendida asociación que sirva de estrecho lazo de amor fraternal entre las clases productoras, y como medio el más valioso y eficaz para que éstas puedan conseguir las reformas que con tanta justicia anhelan, procede insinuar algunos detalles relativos á la más sólida y conveniente organización de las mismas.

Las elevadas ideas emitidas en las importantes Asambleas de Guadalajara, Briones, Junilla, Logroño, Zamora, Cariñena, y otras poblaciones, sobre la conveniencia de formar el gran Partido agricola Nacional, han repercutido y hallado eco fiel en todas las regiones de España, particularmente en las que se encuentran más necesitadas de protección y menos atendidas por parte de los Poderes públicos.

La Unión constituye la fuerza. Esto es axiomático; una verdad clara, inconcusa, evidente y deslumbradora, como la luz del Mediodia, reconocida por todos hasta la saciedad, y por lo mismo ya nadie la pone en duda. También es notorio que la fuerza reside en el mayor número de elementos, pero es cuando éstos pertenecen á una misma especie y se hallan unidos, porque si se encuentran diseminados, aunque homogéneos, 
no pueden llegar á constituir la fuerza que darian sumados. Asi, pues, urge formar un importante y vigoroso núcleo compacto, una gran masa harmónica con la multiplicidad de factores aislados y dispersos entre la numerosa clase agraria; $y$ en nuestro concepto ningún medio más valioso, eficaz y de resultados más prácticos y provechosos que el de un potente y bien organizado Partido Agricola Español. Es por donde debe empezarse el cimiento sólido y compacto para construir sobre éste el suntuoso edificio de la regeneración agricola.

Pero es indispensable la cooperación de todos, porque la importancia de la obra requiere el concurso entusiasta y decidido de todos los productores y cuantos más sean; los asociados y mayor sea su constancia, es lógico que el éxito será más eficaz, inmediato y duradero.

Las protestas aisladas por justas que sean nadie las atiende; pero las grandes manifestaciones colectivas son de una potencia asombrosa cuando se encierran en formas y reglas comedidas, y se fundan en el sacrosanto principio de la equidad y de la justicia.

Es preciso organizarse para harmonizar y favorecer el desarrollo de las fuerza individuales por medio del espiritu unánime de asociación entre las clases productoras, cuya unidad es á todas las sociedades humanas lo 
que la cohesión á los átomos materiales, la cual no puede residir en cada uno de los miembros, sino en la entidad que abraza el conjunto de los intereses particulares para aplicarla en utilidad y provecho de la suma de fuerzas de los asociados; y los que se dedican à la agricultura deben ser los primeros en procurar la unión, progreso y desarrollo de todos los elementos productores.

Los agricultores, á pesar de constituir el aúcleo de la nación, que tantos méritos tieaen contraidos por su prudencia y docilidad, por las muchas calamidades que desde hace años pesan sobre ellos, y por su perseverancia, alentada y robustecida por la resignación y el trabajo, no son atendidos porque les falta el lazo fraternal de la asociación, y su habitual indolencia, es la causa principal del estado en que se encuentran. El abandono y olvido en que yacen relegados es debido à su excesivo silencio y apatía, á su descomunal negligencia y punible descuido, siendo en extremo lamentable que no salgan de su glacial indiferencia después de las severas y elocuentes enseñanzas que han recibido.

Asi, pues, fuera esa apatia, porque es necesario el concurso de todos á fin de constituir un núcleo vigoroso de acción, y la apatía es el enemigo formidable de todo progreso, que enerva, destruye y mata las

CRISIS AGRICLA. 
ideas más legitimas y halagüeñas; congregarse, unirse todos los agricultores en apretado haz en derredor de los augustos pliegues de la bandera de la asociación si no han de quedar como el gallo de Morón, y ser suicidas de sus intereses y los de sus descendientes, ya que tan resignada clase es la menosatendida y más sacrificada que ninguna otra con todo género de impuestos.

Acudid todos presurosos, unidos y compactos, y poseidos del mayor entusiasmo á constituir el gran Partido Nacional, para la mejor solución de los graves é interesantes problemas que afectan de una manera ostensible á las clases productoras. Despertad de vuestro profundo letargo; romped el hielo de vuestra indiferencia; salid de vuestro excepticismo; meditad un poco acerca de vuestra apatía y abandono, y os moverá seguramente á gestionar algo en pró de vuestros intereses. Trabajad al unisono con fé y decisión; procurad reuniros, que cada cual ponga de su parte lo que pueda, los indiferentes salgan de su proverbial y censurable apatia; los entusiastas presten su ralioso concurso, inteligencia, é iniciativas, y que en todos reine una verdadera unión y fraternidad para que triunfen las reformas apetecidas.

La unión de los que trabajan, producen, pagan y fomentan la riqueza publica, es una 
necesidad que se impone por si misma, y conviene que se realice con la mayor brevedad, sin esperar ad Kalendas gracas; pues cuanto antes se propongan y lleven á la práctica las soluciones á que tienen derecho, más pronto habrán de disfrutar de sus beneficiosos resultados.

Quienes deben constituirle.

Los agricultores necesitan organizarse y constituir un partido robusto y poderoso que les haga fuertes en determinados momentos, como necesita salud el enfermo, libertad el cautivo, vista el ciego, habla el mudo, agua el sediento, pan el hambriento, consuelo el afligido, justicia el desamparado, protección el desvalido.

A constituir, pues, y organizar cuanto antes el gran Partido Nacional, agricultores todos, liberales y conservadores, carlistas, integristas y republicanos; debiendo prescindir para ello del matiz político que cada uno profesa ó al que se halle afiliado, y lo mismo los castellanos que los andaluces, extremeños, navarros, aragoneses, vascongados, catalanes, y todos los españoles, pues todos somos hijos de esta hidalga y desventurada nación, y por consiguiente todos hermanos; todos iguales derechos que defender, idéntico fin que perseguir, análogas pretensiones que sostener, y todas á cual 
más justas y sublimes; el reinado de la virtud, el triunfo de la equidad, la glorificación del trabajo.

Además de los labrabores, vinicultores y ganaderos, deben figurar en el Partido Agricola Español, todas las demás clases productoras, que son también poderosos elementos de órden, como los fabricantes y cuantos industriales transforman las primeras materias que produce el agricultor, facilitándole por tal medio inmediata salida y más ventajosa colocación á sus productos; los comerciantes que fundan el buen desarrollo de sus negocios en el estado próspero de la numerosa clase agricola; los propietarios que viven de sus rentas, saben lo que por ellas contribuyen y el peligro de exponerse á perderlas si no se proteje á la agricultura; las ciencias hoy cohibidas, para que puedan desplegar mejor sus grandiosas energias, como igualmente las artes, contenidas en la más amarga inacción; todos los hombres de sensatez y buen juicio que deseen llegar á la regeneración del pais por el camino más firme y seguro; los obreros agrícolas é industriales y cuantos se dedican por fin al verdadero trabajo; porque el malestar de los agricultores cunde y afecta à todas las clases mencionadas.

Establecer una estrecha solidaridad entre todos, desde el más opulento hasta el más 
modesto, lo mismo el rico propietario, que el colono, el ganadero y el humilde obrero, elletrado y el comerciante, el industrial y el artista; así como también el clero y el profesorado, los médicos, 'farmacéuticos, secretarios y demás funcionarios rurales, esclavos del deber, mártires del trabajo, que sacrifican su vida é inteligencia en bien de los pueblos y de los intereses generales de la nación, en particular de los agricolas, y que ven á todas horas las necesidades y sufrimientos del agricultor; todos se duelen de su triste situación, son participes de sus alegrias y sinsabores, recompensas é infortunios, y en su ilustración, desinterés y patriotismo coadjuvarán seguramente con decisión y energía à que sus quejas sean debidamente atendidas.

Solo, pues, quedarán sin pertenecer al gran partido los nómadas y aventureros, los alucinados, los que sin ocupación alguna consumen y no producen, y los que quieren vivir corno los parásitos y absorver la sávia de las clases productoras, los cuales, por más que lo intentasen, no habrian de ser admitidos á engrosar las filas del partido nacional, porque serian como virus ponzoñoso en cuerpo humano, que contamina con rapidez vertiginosa todas las partes de su organismo, si hábil operador no corta oportunamente los tegidos del enfermo y aplica 
sin dilación á la parte afecta el benéfico termocaterio.

Como medio eficaz é incesante de propaganda, y sin perjuicio de las revistas cientificas y profesionales necesarias para ilustrar la opinión, evidenciar las mejores prácticas de cultivo, riego, abonos, semillas, etcétera, será conveniente fundar y sostener publicaciones diarias, sensatas é ilustradas, con todos los elementos de información que exigen las necesidades modernas de la prensa á precios módicos, que muevan y agiten la opinión en favor del partido, amparen $y$ defiendan los intereses generales del mismo y los individuales de los asociados que injustamente sean oprimidos, debiendo seguir, en esta parte, el ejemplo que ofrecen los agricultores franceses y alemanes.

Todos los partidos y fracciones politicas; todas las empresas, sociedades y compañias bien organizadas, tienen en su respectivo periódico, un centinela experto, un defensor constante de las ideas que sustentan, como el más eficaz propagador de las mismas, el cual hace las veces de bandera; y hoy que la prensa es un factor muy esencial é importante en el mundo civilizado, palanca firme de la sociedad moderna; salva guardia de la moralidad, auxiliar activo de la justicia, protectora del trabajo é imán que atrae la opinión pública, no ha de prescindir el 
gran Partido Español de su valioso concurso.

Las muchas contrariedades y desengaños que han sufrido los agricultores deben servirles de lecciones provechosas, alentarles para tremolar la bandera de la asociación y emprender el verdadero camino; pues dividida la clase agrícola, nunca será atendida en sus justas pretensiones, ni logrará nada práctico y positivo, pero unida lo conseguirá todo porque sus gestiones y propósitos llevarán siempre consigo la brillante aureola de la equidad y la justicia; y en tal concepto, una vez organizado el partido, vendrá oportunamente de la periferia, el punto céntrico, un gran movimiento, una acción común y ordenada que acabe de una vez con odiosos privilegios, irritantes injusticias, y salve los intereses y derechos de los abatidos agricultores.

$\mathrm{Ni}$ los meetings, peticiones, ni ninguna otra clase de trabajos darán resultados prácticos, mientras no se halle bien organizado el partido, funcione la Junta directiva y el mayor número posible de Cámaras agrícolas, Juntas ó Sindicatos por provincias, partidos ó regiones, y en cada Municipio una Comisión local, á fin de llevar á la práctica cuanto convenga á las justas aspiraciones de la asociación.

El partido Español ò Nacional, fuerte, compacto, homogéneo, sin ingerencias 
extrañas que no necesita, y con estrecha unidad de miras que, cual centinela experto, vele constantemente por los intereses y derechos de los agricultores, y, como movido por un resorte acuda solicito en los momentos críticos y solemnes alli donde las circunstancias reclamen su valioso concurso, serà para la abatida riqueza agraria, lo que el rocio de la aurora á la tierna flor castigada por los ardorosos rayos solares; el iris de la esperanza; el edén de perfumadas flores; el aura vivificadora; el Moisés que nos ha de sacar de la esclavitud que pesa sobre España; el mensajero de nuestra redención agrícola.

A su acción potente y unánime, aparecerán los capitales ocultos y huidos, renacerá la confianza perdida, las fuerzas vivas del. país alcanzarán mayor recompensa á sus continuos afanes y derechos, y todo será movimiento, vida, entusiasmo. El Partido Agricola Español, será además el símbolo de fraternidad y fuerza, y los sacrificios y esfuerzos de todos confundidos en una sola aspiración, una sola idea, un solo pensamiento y una sola voluntad, habrán de conducir al pensamiento magnifico y patriótico de salvar y engrandecer la riqueza pública, el crédito nacional y el decoro de los productores. 
Fines elevados del mismo.

Por importantes que sean los elementos que se agrupen en torno de los augustos pliegues de la bandera del partido, y por numerosas y bien organizadas las fuerzas que reuna, contra las que no puedan moral ni materialmente cada una ni todas las demás agrupaciones juntas, no por eso habrá de hacer vana estentación de las mismas fuerzas, proceder con miras bastardas, fundar y sostener pretensiones absurdas ó exageradas, ni rebasar nunca los límites de la más correcta prudencia; así como tampoco confiar en el número ó en la razón de la fuerza, sinó en la fuerza de la razón, la fuerza de la lógica, del buen sentido, de la equidad y de la justicia, y proceder con la mayor circunspección y mesura en todos sus actos, procurando elevar la asociación á las más altas proporciones.

a La asociación tiene por objeto auxiliar al hombre en la consecución de sus fines. Para que la asociación dé frutos de bendición, débese tener encuenta que estos fines, como de un sér racional, son trascendentales y se hallan subordinados los unos á los otros. En virtud de la trascendencia de los fines humanos, debe colocarse el órden moral y religioso como fundamento de todos los demás; y en 
virtud de la subordinación, no deben aparecer los fines humanos dislocados de la asociación por excelencia que se llama sociedad civil, ni desarrollarse desmesuradamente los unos con perjuicio de los otros, haciendo crecer unas clases en mengua de otras. Son, en una palabra las asociaciones, un freno saludable impuesto a la ambición de los poderosos y una ayuda para los débiles. Sus medios son, el amor del prójimo, la abnegación y el desinterés: y sus fines, la libertad, la igualdad, la abundancia y la dicha de los hombres (I).

Precisamente en el más puro y acendrado amor al prójimo, es en lo que se funda el principio de la Asociación Agricola, sin olvidar que el órden moral debe servir siempre de base al órden material; porque la religión cristiana es el vinculo que mejor une á los hombres y más estrecha los corazones, y con sus preceptos sublimes y enseñanzas sacrosantas nos facilita los medios para llegar á Dios, fuente de todo bien y sabiduria infinita. Además la religión manda estimar á los desheredados como á propios hermanos, y enseña las verdaderas reglas de la caridad, del deber y del derecho.

También se funda la Asociación en la igualdad ó equidad tributaria, y en un deber

(1) Martinez y González, en su obra ya expresada. 
de recta conciencia que obliga á dar la mano al caido, y á prestar ayuda ó apoyo á los débiles contra las arbitrariedades y opresiones de ios fuertes. Por lo mismo, y puesto que los agricultores ven hoy sus intereses y derechos hollados y escarnecidos, y que más que á la ofensiva tienen que estar á la defensiva, á la vez que sensatez y cordura, conviene demostrar que hay también dignidad y energia para defender todo lo justo, equitativo y razonable que conduzca al mejoramiento de tan numerosa y sufrida clase; pues el gran partido habrá de constituirse para algo más que para servir de figura decorativa, y algún provecho se ha de obtener de las severas lecciones recibidas, debiendo, sin embargo, proceder siempre con discreción, tino y prudencia; pues así como el Estado representa la legalidad y el órden, así también la sociedad Agraria deberá hallarse constituida por elementos gubernamentales de paz y órden exclusivamente, que sirvan á los Poderes públicos de baluarte firme y apoyo valiosisimo para levantar á gran altura todo lo que signifique equidad, instrucción, progreso y bienestar moral y material para la nación.

El partido aAgrícola Español sin olvidarse de la perseverancia y energía, llevará la prudencia por escudo; el órden por divisa; la justicia por bandera; la moralidad por blasón; la templanza por lema; la equidad por 
doctrina; el deber por dogma; la dignidad por culto; el sacrificio por sacerdocio; el patriotismo por religión.

Asi, pues, no habremos de proponer el uso de la fuerza, ni la resistencia al pago de tributos, porque además de no ser legales ni patrióticos tales medios, darian desde luego resultados contraproducentes y funestos.

Para obtener los frutos apetecidos y todo lo que en justicia corresponde á las clases productoras, no precisan ni es tampoco conveniente (pues seria tanto como rebasar la copa) traspasar los limites de una ámplia esfera, ni pedir muchas reformas á la vez sino pocas y bien meditadas.

Conveniencia de su organizacion inmediata para obtener las reformas que tanto interesan á las fuerzas productoras.

Mas asi como el agricultor tiene que esperar para recoger los frutos á que éstos se hallen en sazón, y una vez sazonados, desarrollar su actividad, sus energias y cuidados à fin de no exponerse á perder la cosecha y con ella el producto de sus desvelos, afanes y trabajos, asi tambien el Partido Agrícola necesita hallarse bien organizado y esperar las ocasiones más oportunas y favorables para la consecución de las reformas deseadas, y de todo cuanto convenga á los intereses del mismo. 
Los hombres de Gobierno, como los Diputados y Senadores, no desconocen las verdaderas necesidades de los pueblos y las muchas calamidades que pesan sobre la producción nacional, saben que espera una muerte prematura à la riqueza agraria, en particular á la viticola, y además conocen los remedios tanto profilácticos como curativos ( $\mathrm{I}$ ): buena prueba de ello es que cuando los primeros se hallan en la oposición y los segundos aspiran á representar algun distrito, reconocen la necesidad apremiante de establecer economías, combatir el fráude y la inmoralidad en todas sus manifestaciones, aliviar la suerte de los abatidos agricultores, desarrollar la industria, favorecer el comercio, llamar á tributación todas las fuentes de riqueza; que la vinicultura atraviesa desde

(1) Por más que machos dicen que en Jadrid se ignoran las costumbres, vida y necesidades de los pueblos, que se juzga á las provincias por lo que es la Córte de España, y que siendo la diferencia bien notable, el pais tiene que sufrir las consecuencias de tan sensible apreciación, entendemos que, aun cuando en efecto no se conozcan bien á fondo por la generalidad de los habitantes de Iadrid las verdaderas necesidades de los pueblos, no sucede lo propio á los hombres ilustrès de Estado y á los políticos, á quienes incumbe la aplicación de los remedios para combatir ó atenuar siquiera aquellas; seria demasiada candidez suponer otra cosa. 
años ha una situación tan crítica y excepcional como no se ha conocido otra jamás; que hace falta abrir mercados, modificar las tarilas ferroviarias para que resulten más baratos los transportes de productos agricolas, etc., etc.

Sin embargo de que á su alta penetración no pueden ocultarse tantas calamidades como pesan sobre las clases productoras, muchos las conocen prácticamente, las han patentizado además los ayes de los contribuyentes, los clamoreos de la prensa, la voz latente de la opinión pública, las grandiosas asambleas, multitud de exposiciones razonadas, y hasta en el Parlamento han sido objeto de discusion en virtud de proposiciones suscritas por diputados celosos de los intereses de los distritos cuya representacion se les confiara; siendo de lamentar que unos hayan cedido y otros negado su protección y su voto á las mismas por compromisos de partido, deberes de disciplina ó por consideraciones más ó menos atendibles. (I)

(1) No decimos que por ser incınsecuentes, ó por buscar el sol que más caliente, como se afirma de algunos politicos, ni que tengan por norma de sus actos coinpadrazgos nefastos yernocracias descaradas, medros personales ó ambiciones desmedidas; tampoco que los partidos solo trabajan pro domo sua que vayanos de Scila á Caribdis, que nuestra Hacienda se 
De manera que no puede atribuirse á un desconocimiento de las verdaderas necesidades del pais por parte de nuestros gobernantes y politicos el no aplicar con la mayor oportunidad los remedios conducentes; por lo tanto es preciso ser lógicos y no dejarse llevar por una consideración superficial de las cosas.

Además la ignorancia de las leyes no elude el cumplimiento de las mismas: asi lo preceptúa el Código civil (1), y asi se aplica en la práctica; y cuando un Gobierno conoce los males que sufre el pais y no aplica los remedios oportunos, es un farsante, pues el interés particular no puede ni debe anteponerse, ni ser obstáculo á lo que reclame el interés general; y si los desconoce debe abandonar el poder, hasta que aprenda en la oposición la verdadera ciencia de gobernar y atender las necesidades públicas, con soluciones prácticas y beneficiosas, en vez de remedios

parezıa á la de la tia Pingaja de la que el uno tira y el otro lesgaja, y menos que la política sea un negocio productivo; pues ya hemos expuesto en el Cap. II la que entendemos por politica, deseando no rebajarlà por ningun concepto de su verdadero y alto nivel, sino elevarla, á ser posible, á mayores y más altos vuelos.

(1) Artículo segundo. Lo propio se estableció en la ley 31 tit. 14 Partida 5.a. 
empiricos casi siempre nocivos ó por lo menos ineficaces.

Por otra parte, es necesario reconocer que de los muchos males que los agricultores lamentan, no es responsable solamente partido político alguno determinado, sino que á todos por igual, así como tambien á los mismos agricultores y ganaderos, comerciantes é industriales pudieran aplicarse muy bien los conocidos versos.

¡Llorad hermanos!

¡Todos en él pusisteis vuestras manos!

Cuando la discusión habida en el Parlamento relativa á elevar los derechos arancelarios para los trigos de procedencia extranjera (I), solo se obtuvo un ligero paliativo, no un remedio eficaz ni una satisfacción cumplida á los que demandaban los labradores para poder vender sus cereales al precio que los que liegaban à las costas en partidas considerables.

Planteado el debate sobre el muy interesante problema de la supresión ó modificación del impuesto que grava los vinos (2) al

(1) Debida á la interesante y patriótica proposición del Sr. Lagunilla, y á las gestiones de algunos labradores y Diputados provinciales.

(2) Por virtud de las importantísimas proposiciones respectivas de los Sres. Fernández y la Torre, y de las razonadas peticiones de diversos centros vinicolas. 
terminar la última legislatura, muchos vinicultores que tenian repletas sus bodegas de aquel liquido sin poderlo expender á ningun precio por falta de compradores y próxima ya la época de recoger la nueva cosecha, concibieron una esperanza consoladora, por creer que en breve mejoraría su situación tan angustiosa y deplorable; pero; oh, espejismo cruel de la fatalidad! todo fué una ilusión vana; una decepción triste y amarga; un dulce sueño que se desvanece como el humo en el espacio y solo deja al despertar un triste desengaño.

Una vez mas y en circunstancias bien criticas fueron antepuestas las conveniencias políticas à las necesidades de los agricultores, los intereses de partido á los intereses generales del país. Por más que para algunos fué ya previsto el desenlace, no fué menor la decepción que sufrieron los vinicultorès.

Causa honda pena ver que al anuncio de cualquier debate político, el Congreso se llena por completo, lo mismo los escaños de los Diputados que los asientos de las tribunas; $y$ cuando se trata de resolver alguna cuestión ó problema que afecta á la vida ó muerte de los intereses agricolas é industriales, la indiferencia más olímpica, la soledad más triste impera en el augusto recinto de las Leyes, quedando en él casi solamente los maceros, á

Crisis agrícola. 
manera de testigos mudos é impasibles de aquel cuadro melancólico, presagio de dolor y de amargura.

Algo, sin embargo, se han animado los debates económicos en los últimos años, y se ha prestado mayor atención a las cuestiones agricolas, debido a los continuos ayes y lamentos de los agricultores; pero esto no basta para aliviar su triste situación, porque es poco lo que se ha conseguido en su favor, y lo que es más triste y alarmante aún, sin esperanza de que aquellos sean más atendidos en sus justas quejas, de continuar en su habitual marasmo y apatía, si à las escasasy laudables gestiones de algunas individualidades no a compañan otras colectivas, y si no se reducen solamente á débiles lamentos y al deseo de obtener como de limosna lo que les corresponde por derecho.

Las mismas causas han producido siempre iguales efectos, y para evitar que en lo sucesivo se atienda à principios políticos, á las conveniencias de partido ó á un mal entendido espiritu de disciplina más que al remedio inmediato y eficaz de las apremiantes necesidades de los agricultores, es imprescindible cambiar de sistema y adoptar otros procedimientos, porque cuando no bastan los paliativos para curar un mal, es preciso acudir á un tratamiento más enérgico y de más positivos resultados. 
Si cuando la votación para establecer un recargo extraordinario á los trigos de procedencia extranjera, y posteriormente en la discusión para suprimir ó modificar el crecido impuesto que grava los vinos, la mayoria de los Diputados hubiera estado libre de compromisos políticos para atender solamente $\dot{a}$ los intereses generales del pais, otro resultado diferente se hubiese obtenido, y otra seria la suerte de los productores; pero como estos no se hallaban organizados, ni habian designado representantes por sus fuerzas exclusivas, sucedió lo que era de esperar de un Congreso cuyos Diputados debian muchos sus actas más que á los agricultores al Gobierno que convocó las elecciones, como sucede siempre en España, por el favor ministerial que tanto se prodiga á los candidatos adictos, con objeto de crearse una formidable mayoría, aunque sea á costa de atropellos, vejacio. nes y arbitrariedades, y en desprestigio de la tan decantada sinceridad electoral; otros a los politicos de primera fila, y algunos también, aunque los menos, a sus merecimientos ó simpatias personales.

Al gran partido correspode designar los que hayan de representarle en el Parlamento.

Es necesario, pues, llevar á las Córtes la representación genuina de las legitimas 
aspiraciones del pais, representantes verdad de las clases productoras, á cuya voluntad, más que à la del Gobierno, deban sus actas respectivas: Diputados rurales, hon rados y conocedores de las necesidades de los pueblos, que aun lcuando no sepan una palabra de retórica, ni de política menuda, conozcan por experiencia los muchos y graves males que el pais lamenta, y desligados por completo de toda idea y compromiso político, defiendan con su palabra, y muy particularmente con su voto, los intereses de los agricultores.

Con un personal nuevo, aunque modesto, pero poseido de una voluntad firme y sincera, ya que la voluntad, entusiasmo y energia logran muchas veces más que el poder, retraimiento y apatia; con nuevos procedimientos, pero más breves, claros y sencillos en Politica y en Administración; con menos discursos y más resoluciones; menos oradores y más productores, mejorará indudablemente la condición de las clases agricolas; pues con muchos proyectos y muchos discursos floridos, muchos distingos y subterfugios, aunque adornados con frases galanas, no se remedian, ni alivian siquiera, los muchos males que sufren los agricultores. Pocos proyectos, pero más prácticos y equitativos; poca, muy poca oratoria, pero más ajustada à la razón y á la justicia. 
Pero si se ha de llegar á tan importante resultado, es preciso que el Partido Nacional esté bien organizado para cuando se convoque el cuerpo electoral, pues en el importante y solemne acto de la elección de Diputados á Córtes y Senadores, es cuando el gran partido debe mostrar mejor su vigorosa organización; entónces es precisamente la mejor época para que los agricultores salgan de su lamentable indiferencia y excepticismo, y trabajen todosjuntos con decisión y entusiasmo para no verse tan vejados y oprimidos; saber aprovechar la oportunidad, porque una vez sazonado el fruto, si no se recoge á tiempo, se reduce considerablemente, deteriora ó inutiliza, siendo despues necesaria nueva semilla, nuevos sacrificios y un tiempo precioso para poder utilizar el de otra cosecha más ó menos remota.

Mas para que las futuras campañas legislativas no sean tan infructuosas como las anteriores, es indispensable que el cuerpo electoral independiente, el Partido Agrícola, estudiando fría y serenamente la realidad á la clara luz de la razón y de la justicia, forme el programa y designe los candidatos que le hayan de representar (I); pues asi como

(I) Los que aspiren á representarnos en Córtes, Diputaciones y Ayuntamientos, para obtener nuestros rotos jurarán y firmarán los capítulos siguientes: 
éstos, en vísperas de elecciones, acostumbran à dirigirse á los electores con pomposos ofrecimientos que después algunos suelen olvidar fácilmente, ó se, trasladan à la calle del Sordo, tal vez al recuerdo castellano una cosa es predicar y otra dar trigo, que sean los mismos candidatos los que sin ambigüedades se coloquen con franqueza y resolución inquebrantable, y se sımetan prévia y solemnemente á defender en el Parlamento, sin vacilación alguna y con el mayor denuedo los

1. ${ }^{-}$No aceptarán cargos retribuidos por la nación ó por las grandes empresas para sí, ni para sus próximos parientes, y no tendrán negocios de ninguna clase con el Estado, durante el tiempo de aquella representación, ni en tres años después.

7. Pedirán la reducción del 25 por 100 en los sueldos que excedlan de 10.000 pesetas, incluso la lista civil, y en los que no lleguen a 5.000 se decidirá ó convendrá aumentarles el 25 por 100, luego que se haya conseguilo la amortización de los cargos. Porque hemos de aspirar á tener los empleados necesarios, nada más, pero bien retribuidos, para contener la corrupción á que conduce muchas reces la necesidad.

9. Exigirán que toda la riqueza tribute en igual proporeión, incluyendo los valores de la Deuda Pública.

10. Defenderán é impondrán el sistena decididamente proteccionista arancelario.

(Martin Contreras, en su obra La Revolución Agraria). 
intereses de los productores, hasta imitar si fuese necesario, a los héroes de Numancia y Sagunto, vencer ó morir, triunfar ó quedar hourosamente derrotados.

Que se decidan franca y resueltamente á servir á César ó á Pompeyo, para deslindar de una vez los campos y marchar al vado ó á la puente; el que no esté con los agricultores, estara contra los agricultores. Tal debe ser el dilema, pues con la intención sola no basta, es necesario ver para creer, y creer por haber visto, y de nada sirven los sofismas de burda urdimbre para querer ocultar ó desfigurar la verdad de los hectios, porque todo ello no es más que logomaquia vana, ópio que embriaga por determinados momentos, pero que en vez de fortalecer, debilita; y sabido es que los hechos tienen siempre mayor fuerza y lógica que las ideas y palabras, pues conforme con el antiguo adagio, obras son amores, y nu buenas razones.

No debe olvidarse que la consecución de las reformas que con tanta justicia persiguen los agricultores depende de las Córtes, y por tanto de los Diputados que se elijan habrá de salir el apoyo más ó ménos entusiasta y sincero, y principalmente su voto ya en pró, ya en contra de las mismas; porque no está sólo en Madrid, como residencia del Gobierno, la culpa de nuestros males, sino en los Diputados que no cumplen son su deber, según dijo 
el Sr. Cañella (I); como asi es, en efecto, pues siendo en su mayor parte tan dóciles ante el titulado deber de disciplina, dán sumisos sus votos al Gobierno, sacrificando los intereses sagrados del pais à los intereses egoistas de la política.

Al Partido Agricola es al que corresponde designar los Jueces que han de sentenciar su propia causa, y por consiguiente, cuando se convoquen elecciones (2), es necesario que se mueva y agite, como se mueve un campo de espigas sacudidas por dos vientos contrarios, y aprestarse à la lucha, cual el Segismundo ideado por el inmortal Calderón, á fin de romper las fuertes cadenas del olvido en que se tiene á las clases productoras (3).

Por lo tanto, también le corresponde recabar de los candidatos una promesa formal y séria de que han de apoyar resueltamente

(1) En la Asamblea vinícola celebrada en Tarragona el 1.' de Junio de $\mathbf{1 8 9 5 .}$

(2) Ya que casi nadie se acuerda de los agricultores más que al vencimiento del trimestre de la contribución y cuando se aproximan las elecciones.

(3) En vez del retraimiento que se observa en toda clase de elecciones y la indiferencia en los cambios politicos, indiferencia peculiar de nuestra musulmana resignación á que aludía el insigne Bretón de los Herreros cuando exclamó: "Cualquier ley que se promulgue,-al pez chico engulle el grande;-no faltará Rey que me mande,-ni Papa que me excomulgue». 
las aspiracianes de los productores, imitando al efecto la conducta de los insignes aragoneses, cuando por medio de su representante (I) dirigian al nuevo Rey, para que éste pudiera funcionar, las siguientes palabras: «Nos, que valemos cada uno tanto como vos, é todos juntos más que vos, os facemos Rey, si nos guardáredes nuesos fueros é nuesas libertades, é si non, non"».

Y el Monarca no quedaba en posesión del cetro hasta después de jurar guardar los fueros (2).

Pues de la propia manera cada vez que se convoquen elecciones, el gran partido debe distinguir el oro del oropel y decir á sus candidatos: "Nos, los productores, que reunimos las nueve décimas partes de los sufragios de la circunscripción ó distrito electoral, si jurais defender en el Parlamento con decisión y entusiasmo nuestros intereses y derechos, votaremos todos en vuestro favor para que seais Diputados, é si non, non ».

Cuyo sencillo medio, ó el de ofrecer siquiera con caballerosidad los candidatos

(I) El Justicia ó Nagistrado elegido por las Córtes cuyo poder era superior al de los Tribunos de pueblo romano.

(2) Ya en el siglo VII el Concilio $4 .^{\circ}$ Toledano al cap. 75 fulminó anatema contra todo aquel Rey que faltara al respeto debido á las leyes ó abusare de su poder para tiranizar y oprinir á los pueblos. 
antes de la elección que están dispuestos á triunfar ó morir bajo los augustos pliegues de la bandera del partido defendiendo su programa, pudiera contribuir eficazmente à llevar á la práctica, en plazo no lejano, aquellas urgentes y salvadoras reformas que el pais reclama como de necesidad imperiosa, á fín de que tanto en lo político como en lo administrativo, en lo moral como en lo material suceda, impere y consolide lo fijo y legal à lo anormal y arbitrario.

Si lo que no es de esperar, algun Diputado electo en la forma insinuada, faltare á lo que hubiese aceptado y prometido, ó atendiere sólo con tibieza al programa y à las aspiraciones del partido, entónces en el pecado llevaria la penitencia, porque sería desautorizado públicamente, y su nombre borrado de Ja lista honrosa de representantes del Partido Nacional, relegándole à completo olvido y á la impotencia política.

Por el contrario, el que sacrifique comodidades de hogar y de familia, afecciones de partido y conveniencias políticas para atender exclusivamente á remediar las necesidades de las clases productoras, que son las del pais, sin mirar al interés individual más que al supremo de la pátria, y dar gallardas pruebas á las naciones civilizadas que España tiene hijos ilustres y esclarecidos que saben posponer los ideales politicos al bien de la 
nación, merecerá gratitud profunda y eterna el aprecio y consideración de todos los buenos españoles, y que se eleve en honor suyo un suntuoso pedestal que inmortalice su gloria y su nombre.

Asi, pues, á unirse, estrecharse en apretado haz agricultores todos, y proceder con perfecta unidad de apreciaciones, para que todas las fuerzas obren en igual dirección, y pelear como un solo hombre por la razón, la equidad y la justicia, como quien se ve obligado á luchar por la existencia.

Acortad las distancias y diferencias que medien entre unos y otros, para hacer ver $y$ oir á los que permanecen ciegos y sordos; cesen las divisiones, acábense de una vez los antagonismos y discordias, pues en el Partido Nacional no habrá incompatibilidad con ninguna idea ó simpatía politica y para el que todos los Gobiernos serán buenos si se ocupan más del bien del país, que de las conveniencias políticas; pues así como algunos consideran mejor impuesto al más reducido, así tambien conforme con el poeta inglés el mejor Gobierno sera el que mejor administre, llámese como se quiera.

Cuando un buque sufre averias hallándose en alta mar, lejos de la costa, y amenaza irse á fondo, todos sus tripulantes y pasajeros deponen odios, diferencias y rencillas y acuden todos unánimes, solícitos y presurosos, 
colocándose cada cual, en el puesto que le corresponde aunque sea el de mayor peligro, á fin de evitar el terrible naufragio que de otra manera sería inevitable. Pues bien, preciso es reconocer que un naufragio é inminente amenaza á los agricultores, si estos no procuran unirse y poner entre todos los medios conducentes para evitarle. Por lo tanto haya unión, arma invencible; fé, abnegación y perseverancia; pues la fé, la constancia y el trabajo por las grandes ideas, vencen todos los obstáculos por insuperables que sean.

La unión constituye la fuerza (1).

Todo reino dividido será desolado (2).

No debe olvidarse el conocido axioma si vis pacem para bellum, que como ha dicho Montesquien, las naciones tienen siempre los Gobiernos que se merecen; y quesegun Hegel, todo pueblo débil carece de derechos. Por consiguiente, á fin de aparecer los agricultores fuertes y robustos, y que sean atendidos en sus legitimas aspiraciones, deben organizarse sin pérdida de tiempo; todos en general y cada uno en particular; segun su esfera, poner de su parte cuanto pueda; trabajar con decisión y entusiasmo, no cejar un solo

(1) Proverbio francés.

(2) L̉uc. XI.-17. 
momento y mostrarse tan fuertes en la lucha como generosos en la victoria (1).

Ha llegado el momento de obrar sin dudas ni vacilaciones, y de esperar es, que las fuerzas productoras se organicen en breve para decidir el plan general de batalla, dar en su día el paso de avance, sacar de las urnas hombres de integridad y rectitud que hagan sentir el peso de la justicia $y$ la equidad en todas partes, y conseguir por las vias legales el triunfo de las reformas deseadas. Los desengaños sufridos son muchos, el hambre aprieta, y como ésta no admite espera, no es de creer que aquellas atenten contra su vida, su dignidad y sus intereses.

Es indispensable que los agricultores se asocien y vivan prevenidos, y que se decidan á intervenir directamente en la gestión de los intereses públicos, porque en las elecciones de representantes en Córtes y en el debido acierto para designar candidatos (2) estriba

(1) Ya se lian agotado todos los recursos de la súplica; celebrado importantes asambleas, contestado interrogatorios tan extensos como complicados; dirigido multitud de exposiciones á las Córtes y hasta el Trono, y todo, todo hasta la fecha, ha resultado ineficaz; todo se ha reducido á gastar inútilmente papel sellado y perder tiempo.

(2) El resultado de la discusión de los Presupuestos en las postrimerias de la última legislatura no ha 
el remedio más eficaz y de mejores resultados para la solución de los problemas que afectan de una manera directa é indirecta á las clases productoras (I).

Si la necesidad es una gran consejera, desde luego nos atrevemos à asegurar sin temor de ser desmentidos, que hoy no hay otra tan perentoria, como la que siente la abatida clase agraria; y que á esta por más que no ostente ninguna idea politica, la sería en extremo conveniente fundar sus actos y resoluciones en este principio: agricultores antes que políticos; pero atender á la política y tener en ella representación directa, para todo cuanto conduzca el más breve y eficaz remedio de los males que la clase lamenta.

podido ser más infecundo para la producción nacional. De ella hemos sacado la convicción que ninguno de los dos partidos militantes acepta un impuesto verdad sobre la renta, ni la supresión ó rebaja del que grava los vinos. Hay que esperar á que se reunan nuevas Córtes y elegir representantes que se interesen de veras por la numerosa clase agricola.

(1) Debiendo los agricultores adoptar igual sistema en las elecciones de Diputados provineiales y Ayuntamientos, para llevar de este modo su savia fecundante y su representación á todos los organismos politico-económico administrativos, y que prevalezcan con mayor facilidad sus derechos y legítimas aspiraciones. 
Pero no todo puede conseguirse en un dia; pues así como las espigas germinan poco á poco, asi tambien convendrá pedir por partes porque la multiplicidad de reformas, com. plicaria la consecución de las mismas; huir de todas aquellas que no sean justas, y presentar soluciones practicas y viables (I); debiendo perseverar en ellas con firmeza y resolución inquebrantables, por aquella sentencia latina Gulla caval lapidem, pues pretender alcanzar de un sólo golpe todas las reformas deseadas, aun que muy justas y de reconocida converiencia y equidad, sería un sueño ó ilusión quimérica; como el pretender subir de un salto todos los escalones de un edificio

(1) Por alıora las que conceptuamos más urgentes é indispensables para el fomento de la riqueza agraria son las siguientes:

1. La supresión del impuesto sobre los vinos, aun cuando solo sea con el caracter de provincial hasta tanto que mejoren las circunstancias tan críticas porque atraviesa la vinicultura.

2. Prohibición absoluta de importar en España é Islas Baleares cereales y harinas procedentes del extranjero; la cual cesará cuando las circunstan cias aconsejen y requieran la suspensión de tal medida, á fin de permitir únicamente la entrada de la cantidad necesaria para completar el déficit que resulte entre la producción y el consumo.

3.' Elevar el impuesto de 1:25 pesetas, treado por el art. 56 de la ley de Presupuestos del Estado de 30 
elevado, que aun cuando no fuese una otopia, convendria en algunas ocasiones reconocerlos por su orden; pues con celeridad suma no se purifican los organismos crónicos viciados.

Una vez constituido el gran Partido Español deberá ejercitar una propaganda tenaz y asidua y tener bien organizadas todas sus fuerzas para cuando el tiempo y las circunstancias indiquen la forma de emplearlas, ya que la defensa tendrá que basarse en actos proporcionados á los perjuicios y desaires que reciba, pero nunca para combatir por sistema ó capricho determinadas soluciones; porque no siendo una asociación política, ni que se proponga medrar á su sombra, habrá de ser justa, imparcial y rozonable, é inspirar todos sus actos en el más puro y acendrado patriotismo.

de Junio de 1895, sobre los intereses ó dividendos anuales de todas las Deudas y valores públicos, á otro más ejecutivo y más en harmunia con lo que tributan las riquezas rústica, pecuaria y urbana; la industria y el comercio; las profesiones del orden civil y judicial, $\mathrm{y}$ las artes y oficios.

Y 4." La unificación y rebaja de las tarifas de ferrocarriles para los transportes de productos agrícolas, desde los centros productores á las costas y fronteras.

(Sin renunciar à las demás reformas que se mencionan en la presente obra, ni á la de cualquier otra que fuese beneficiosa para la producción nacional.) 
La Asociación también podría hacerse ex. tensiva á todo lo concerniente, á la aplicación de modernos aparatos de cultivo, fundación de centros exportadores de productos agricolas, socorros mútuos, etc. etc., pero no es nuestro ánimo dar reglas fijas y concretas, porque estas no son invariables, como las leyes de la física y astronomia, ni las soluciones que pudiéramos presentar, tan axactas como las matemáticas, sino que dependerán necesariamente de circunstancias especiales, y que por lo mismo deberán ser modificadas según la época, leyes, experiencia y las mismas circunstancias aconsejen.

Por lo tanto, y sin perjuicio de las modificaciones que el tiempo, la práctica y las condiciones especiales de cada provincia, región ó localidad exigieren, creemos conveniente transcribir á continuación las bases sobre las que se ha constituido la Asociación agricola de la provincia de Guadalajara, para que tan loable conducta pueda ser imitada por los productores de las demás provincias españolas.

1.2 Se constituye en la provincia de Guadalajara una asociación con el nombre de Asociación de Agricultores de la provincia de Guadalajara.

2. La Asociación tiene por objeto:

(a) Recabar de los poderes públicos leyes reduciendo las contribuciones por riqueza

Crisis agrígola. 
urbana, rústica y pecuaria la rectificación de las cartillas evaluatorias.

(b) Defender los intereses de la clase agricola, ganadera, é industrial agrícola.

(c) Estrechar la unión y buenas relacio. nes que debe haber entre los individuos de la clase, asi como entre las corporaciones análogas.

(d) Conseguir economias y simplificación en los servicios públicos.

(e) Trabajar para establecer en el más breve plazo pasible el crédito agricola é industrial en la provincia.

(f) Obtener reformas para coadyuvar á este fin en la ley Hipotecaria, y en las de Notariado, Timbre y Derechos reales, facilitando la transmisión y titulación de la propiedad inmueble.

(g) Promover el desarrollo y adelanto de la agricultura, ganaderia, é industrias de ellas derivadas.

3. La asociación jamàs se ocupará de otras cuestiones que las propias de su instituto, prohibiéndose completamente las politicas y religiosas (I).

(1) Conformes en que la asociación sólo se cuide de los asuntos propios de su instituto, si bien conceptuamos que, a! menos por ahora, no deben abandonarse en absoluto las cuestiones políticas que puedan 
4. La asociación estará dirigida por una Junta provincial, cuyos cargos serán honorificos y gratuitos, compuesta de un presidente, dos vicepresidentes, un secretario general, un tesorero y diez vocales. Además formará parte de la Junta provincial, aunque sin voto, un secretario contador retribuido.

5." Se establecerán Juntas de partido, en las cabezas de los antiguos distritos judiciales; y Juntas municipales en todos los pueblos que se adhieran.

6. La Junta de partido será nombrada por los que hayan sido y sean individuos de su Ayuntamiento y los tres mayores contri. buyentes de cada pueblo de su jurisdición que concurran á la elección. La Junta se compondrá de siete individuos cuando menos.

$70^{2}$ Las Juntas municipales serán nombradas por todos los contribuyentes y constarán por lo menos de tres individuos.

8." La asociación celebrará Junta general ordinaria una vez al año, y las extraordinarias que las circunstancias exijan, debiendo mandar representantes las Juntas de partido y municipales constituidas.

9." Los detalles de organización y administración de la asociación, forma de funcionar

ser favorables a los interesantes fines que aquella persigue; ó lo que es lo misno, agricultores per se, politicos per accidens. 
la Junta provincial de partido y municipales, serán objeto de un reglamento especial, inspirado en las presentes bases.

\section{Disposición transitoria.}

Aprobadas las bases antedichas en la reunión del día 23 de Enero de 1895 y nombrada la Junta provincial, ésta redactará el reglamento á que se refiere la base $90^{\circ}$, y procurará imprimir á la Asociación de Agricultores de la provincia de Guadalajara la vida y desarrollo necesarios para realizar sus nobles tines).

Si como dijo Séneca, de pequeñas semillas nacen grandes plantas, la asociación de Guadalajara, protoplasma de una importantisima asociación agraria, no dudamos que ha sido derramada en terreno feráz, y que habrá de germinar, desarrollarse y vivir con lozania para que sirva de provechoso ejemplo á los agricultores de las demás provincias (I) á fin de que se estimulen á ejercitar un derecho natural y legitimo, anterior y superior a

(1) Con gusto observamos que en Salamanca, Logroño, Tarragona, Villena y otras poblaciones se han intentado análogos propósitos, y en lá asamblea celebrada en Briones el 23 de Junio próximo pasado, el Sr. Conde de Hervias leyó un bien meditado proyecto de reglamento para la formación del gran Partido Agrícola. 
toda ley, que tiene el hombre de sustituir. por medio de la asociación las escasas fuerzas individuales que posee por el esfuerzo de la colectividad, hoy más que conveniencia, de necesidad perentoria que constituye un deber ineludible, y sagrado en todos los buenos españoles amantes de la producción nacional para salvar los intereses más vitales de la nación, que son también los del pais entero; pues sabido es que cuando la agricultura florece, el comercio prospera y la industria se desarrolla de una manera prodigiosa.

Pero es necesario no desmayar ni retroceder aunque todas las aspiraciones no se vean realizadas tan pronto como se deseen, sinó trabajar cada vez con mayor firmeza y con una perseverancia alentada y robustecida por la convicción y la esperanza, y tener fe en el porvenir, porque lo que mucho vale, mucho cuesta; y asi como no es victoria la que se obtiene sin dificultades, tampoco es satisfacción la que no se ha logrado á costa de algunos sacrificios.

Para vencer las dificultades, es necesario colocarse ántes en situación de afrontarlas; como para cosechar es necesario sembrar primero. La tierra de buena calidad que está sin labrar, es la que más necesita el trabajo del agricultor para que preste mayores rendimientos; y las montañas de gruesas rocas son más dificiles de perforar que las de 
movediza arena, pero después quedan más firmes y subsistentes que éstas. Mas de la propia manera que la vida de todo ser está ligada al concurso de diversos factores biológicos, así también es necesario el concurso de los elementos vitales del pais, y que entre todos exista un enlace como el que media entre la causa y el efecto, el principio y la consecuencia; y por lo tanto, para emprender la lucha de reconquista (sin salir nunca de los limites, ni de las reglas que la prudencia y la previsión aconsejan) y evitar los males sin cuento que nos esperan, es indispensable la unión, fraternidad y enlace de todas las fuerzas productoras, que son poderosos. elementos de orden, fuerza y prestigio, y las de todos los buenos campeones entusiastas de la prosperidad nacional debiendo proceder en todo con identidad de miras, pareceres $y$ aspiraciones, sacrificando siempre el interés. particular al bienestar colectivo, no ya solamente por buscar la aureola de hacer bien à sus semejantes, sinó para cumplir la misión tan grata y placentera que á los pueblos como á los individuos les ha encomendado la historia, y contribuir todos á la regeneración $y^{2}$ engrandecimiento del pais en que vivimos y que tanto amamos.

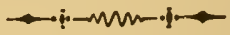


PARTE SEGUNDA

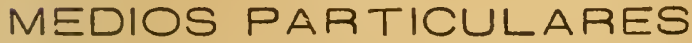

\section{CAPITULO PRIMERO}

\section{La riqueza vinicola.}

1. La aflictiva situación porque atraviesa la riqueza vinicola, requiere urgentes y eficaces remedios.

2. El exceso de producción vinícola origina en primer lugar la grave crisis porque atraviesa tan importante riqueza.-Error lamentable de muchos viticultores.

3. Para facilitar el consumo y venta del vino, es necesario elaborar buenas clases.Los vinicultores deben atender másá la calidad queá ía cantidad; por ser más difícil vender que producir.-Primas á los que elaboren buenas clases de vinos.

4. La escandalosa fabricación de vinos artificiales, y la adulteración delos naturales, hacen aumentar el exceso de produccióny disminuir el consumo.-Penas severas á los fabricantes y expendedores de vinos artificiales ó adulterados.

5. Conveniencia de acrecentar el consumo interior en España. - Medios eficaces para ello.

6. Mercados extranjeros.-A pesar de los medios propuestos es de necesidad por aho$\mathrm{ra}$, abrir nuevos mercados y consolidar los antiguos.-Primas á los que exporten vinos en proporción á la cantidad y clase del producto.-Sindicatos de exportación, estaciones enotécnicas, agencias consulares y exposiciones. 
La aflictiva situación porque atraviesa la riqueza vinícola, requiere urgentes $y$ eficaces remedios.

Cuando una oveja se ha descarriado, lo primero que hace todo el buen pastor amante del cumplimiento de su deber, es procurar atraerla al redil, aun cuando para ello tenga que abandonar momentáneamente todo el rebaño (I); como un médico solícito por la salud de sus enfermos, cuando uno de éstos se encuentra en inminente peligro, ó siquiera de alguna gravedad, consagra sus afanes y desvelos á combatir y alejar el mal del paciente, cuidándose entre tanto, muy poco de los enfermos leves, y nada de los clientes que están sanos, por lo mismo que no precisan utilizar sus servicios, mientras permanecen en tan grato é interesante estado de salud, asi también los buenos Gobiernos que, estimando los problemas agrícolas en lo mucho que valen y representan, deben atender con preferente celo á evitar la ruina de las más importantes ramas productoras y muy en particular si se encuentran en un estado de postración, y en el peligro inminente de desaparecer, que lo está en la actualidad la riqueza viticola y vinicola.

(1) Joan X.-2. 
No exageramos y jójala que nuestra aseveración fuese exagerada!; pero cuando el mal existe, mejor que ocultarle y alentar esperanzas que después se conviertan en tristes desengaños, es preferible, aunque doloroso, evidenciarle con toda claridad; entendiendo que de tal manera es como mejor se puede aplicar el remedio.

Como prueba de que no es exagerado nuestro aserto reproducimos las dos siguien. tes noticias que la prensa periódica publicó en Septiembre de 1894 .

«Por la escasez de transaciones y la depreciación en que se hacen las pocas que se verifican, los labradores de Alginet (Valencia) están regalando la uva de la presente cosechan.

"Los cosecheros de vinos de casi todos los pueblos de Aragón se ven precisados á tirar sus cosechas por la falta absoluta de compradores».

Y lo propio que en Aragón y Valencia sucedió en Navarra, en muchos pueblos de la ribera del Duero y en otras importantes comarcas productoras; habiéadose repetido tan triste espectáculo en 1895 , pero en proporciones verdareramente desconsoladoras.

Las circunstancias tan graves, porque atraviesa nuestra riqueza vinicola, exigen imperiosamente soluciones prácticas é inmediatas. 
La riqueza vinicola es la principal y casi única en muchas regiones de España, fuente la más copiosa de prosperidad, y la más importante de todas, á lo menos por lo que atañe á la exportación.

El vino es un artículo de primera necesidad, porque constituye el complemento de una alimentación sana, no solamente para los enfermos, si que para todos los que disfrutan perfecta salud, para las altas clases sociales y más aún para los obreros por ser una bebida tónica, y mucho más apropiada que la cerveza, el coñac y demás bebidas espirituosas artificiales (cuyo abuso ocasiona infinitos males) para adquirir vigor, y reanimar las fuerzas musculares que tanto necesitan á fin de poder resistir las rudas tareas á que diariamente se dedican.

Por otra parte el cultivo de la vid es el que más braceros sostiene puesto que en él están trabajando todo el año, particularmente en los meses del invierno y primavera, siendo más que conveniente, muy necesario cultivar bien las viñas, no sólo para obtener más y mejor cantidad de vino, sino que también para que estas no sufran pérdidas o deterioros; pues ya es sabido que las tierras dedicadas á cereales aun cuando no se labren en varios años, nada pierden, descansan como dicen algunos labradores, $y$ 
suelen dar mayor rendimiento después (1); mientras que el viñedo, si un sólo año no se poda, queda ya casi completamente destruido, siendo luego necesarios largos años $\mathbf{Y}$ muchos sacrificios para reponerlo: y aun cuando no suiceda lo propio con otras operaciones, también esenciales, como las de cava, arada, acobijo, bina y demás concernientes á meteorizar el terreno y limpiarlo de malas yerbas, es lo cierto que sino se practican oportunamente todos los años, producen menos y son más costosas las labores: de ahí la conveniencia y el mucho interés que reporta á los propietarios cultivar con el mayor esmero y oportunidad sus viñedos, y por ende el sostenimiento de numerosos obreros que practiquen tan lentas y variadas operaciones; ya que para el derrame, acobijo y poda no se usan, que sepamos, máquinas, ni artefactos, como para la siembra, siega, trilla y limpia de cereales.

(1) Sin que esto sea negar las ventajas de una bien combinada alternativa de cosechas, como más conveniente a la producción que el barbecho; según afirman ilustrados autores como Cortés y Morales, Oliván, Quintana y otros. 
El exceso de producción vinícola origina en primer lugar la grave crisis porque atraviesa $\tan$ importante riqueza.

El viñedo, además aporta una suma considerable por contribución territorial y recargos municipales, pues cuando el comercio de vinos en Francia empezó hace cerca de veinte años á tomar tan raudo vuelo, debido á que la fatalidad llevó la terrible plaga filoxérica à importantes regiones viticolas, muchos agricultores españoles ante la creencia errónea de que la crisis vinicola de allende el Pirineo sería duradera, empezaron á plantar viñas sin cálculo ni medida, dedicando á este asunto todo esmero cultural, por lo que se hicieron productivos considerables terrenos antes eriales y baldios que no contribuian y otros (I) dedicados á cereales que posteriormente han sido comprendidos en los apéndices y repartimientos respectivos, con el liquido imponible consiguiente los primeros, y con los aumentos que, según tipo de las cartillas evaluatorias, ha correspondido à los últimos.

Cierto que no pensaron, los que tal hicieron, que llegaria día, como desde hace años y en la actualidad sucede; que las bodegas

(1) Aunque no todos, como queda expresado en la Parte primera, cap. V. 
españolas se verian llenas de existencias, sin poder dar salida á los vinos, ni aun á precios extremadamente reducidos, y en muchas ocasiones, hasta para vender poco, y en pequeñas cantidades, los cosecheros de buena fe tienen que pasar infinidad de molestias y sufrimientos; pero el mal subsiste, y es preciso emplear con urgencia el remedio.

Las nuevas plantaciones escogidas, por regla general entre las que pudieran dar desde luego no mejor, sino mayor volumen ó cantidad de uva, después de un plazo más ó menos largo, han dado en efecto exuberantes frutos, habiendo elevado la producción desde quince á veinte millones de hectólitros que se obtenian antes de 1880 , hasta más de treinta, y aun cuarenta que en años abundantes hoy se producen.

Tenemos, pues, un gran exceso de producción muy superior á las necesidades del consumo y de la exportación, y será à no dudarlo cada vez mayor á medida que vayan dando fruto las últimas plantaciones.

¿Cómo remediar el mal? Este desgraciadamente no es exclusivo en España, pues en Argelia, Australia, Austria-Hungria, la Dalmacia, Italia, Portugal y otras naciones en que el clima y el terreno son à propósito para el cultivo de la vid, se encuentran respecto á tan importante particular en circunstancias idénticas á las nuestras, y, por lo mismo, en 
lo que à la exportación atañe, tendremos que luchar con mayores dificultades para vencer en honrosa lid à tan diligentes, constantes y entendidos competidores.

«No son puramente, á nuestro modo de ver, motivos locales que determinan el malestar actual de la vinicultura. Son causas múltiples, completas y no pocas de carácter internacional las que han dado por resultado la terrible crisis porque atraviesan todos los paises productores de vinos, crisis en algunos de ellos peor que la que ocasionó la filoxera, porque los capitales dedicados á las viñas se pierden, los esfuerzos resultan vanos y las esperanzas fallidas, no viéndose en lontananza más que inseguridades y zozobras, por no decir ruina y miseria.

Y si esto lo notan en Francia, pais rico y de relativo bienestar, puede calcularse lo que podrán decir España, Italia, Portugal, Grecia, Turquia, etcétera, en donde la producción supera mucho al consumo y á su escasa exportación. Para nosotros, lo repetimos, el desequilibrio procede principalmente del exceso de protucción en todo el mundo y de lo limitado que es el consumo en los paises que no lo producen (I).

(i) Director de la Estación Enotécnica de España en Cette. (9 Diciembre 1893). 
Nada diremos respecto á la prohibición de nuevas plantaciones (I), por más que el dilema entre abrir nuevos mercados donde colocar todos los vinos sobrantes, ó no permitir mayor número de vides parece que no admite la menor controversia; y no se concibe por otra parte que un cosechero dedique sus propiedades, cuidados y dineros á un cultivo ó elaboración de lo que sabe que después no ha de tener consumo. Sin embargo tan radical medida tal vez sea necesaria más adelante para que resulte mayor equilibrio en la producción, si lo que no es de esperar, continúan las plantaciones en tan asombrosa escala como en los tres últimos años; pero por lo que al presente se refiere entendemos suficiente, sinó á remediar el mal en absoluto, por lo menos á atenuarle en sus deplorables consecuencias, la imposición de un nuevo tributo ó aumento de gravamen sobre los ya establecidos, á las vides que se planten en lo sucesivo (2).

(l) Establecida antiguamente en España y fuera de ella.

(2) Así lo proponemos en la Parte 4." 
Para facilitar el consumo y venta del vino es necesario elaborar buenas clases.-Los vinicultores deben atender más á la

calidad, que á la cantidad, por ser más difícil vender que producir.Primas á los que elaboren buenas clases de vinos.

Una de las condiciones más esenciales para el consumo y venta de los vinos es la buena elaboración de los mismos.

Que la elaboración actual de los vinos es súmamente defectuosa, no es preciso demostrarlo, porque es sabido hasta la saciedad y está en la conciencia de todos. Hay algunas honrosas excepciones, como sucede en todas las clases sociales; pero la mayor parte de los cosecheros desconociendo, casi en absoluto, lo que debe ser una buena elaboración, y como si se tratara de cualquier particular ó detalle insignificante y sencillo por demás; se cuidan, con grave error suyo, más de la cantidad que de la calidad. Para algunos el objeto principal es producir mucho, aunque la uva no seà la más selecta, y después lá elaboración del vino deje bastante que desear, creyendo equivocadamente que para elaborar clases potables basta hacer la recolección de la uva cuando se halla más madura, exprimirla cuanto puedan, y abandonar 
luego el mosto en las bodegas, con lo cual ya no precisan mas.

Muchos cosecheros aunque tengan mal vino, y olvidándose que es más dificil vender que producir, confian en poder lograr buena venta, y algunas veces lo consiguen, aun cuando les suceda lo mismo que á los labradores que cultivan mal las tierras, que es rarisimo el año que hacen buena cosecha de cereales, y como á los que juegan á la loteria, que llevan treinta probabilidades en contra y una sola en su favor, pero es lo cierto que con tal manera de proceder perjudican à otros cosecheros que, si no reunen todos los conocimientos necesarios para elaborar buenas clases, se esmeran cuanto está de su parte para obtenerlas, por más que despues tengan que venderlo, no cuando quieran, sino cuando puedan, al mismo y en ocasiones á más reducido precio que lo de aquéllos (I); pues algunas reces también sucede que lo malo hace abaratar lo bueno, y lo que es mas sensible, desprestigiar nuestros caldos tanto en el interior como en el exterior.

Es necesario que se persuadan los vinicultores de la necesidad de elaborar buenas clases, procurando adquirir los conocimientos especiales que son necesarios para ello,

(1) Y aún tenerlo que arrojar á la calle por falta de compradores.

Crisis agricola. 
y huir de la rutina y apatia, pues lo bueno. y más aún lo selecto tiene siempre aceptacion (I); que no es lo mismo producir que elaborar; lo primero corresponde exclusivamente á la agricultura, y lo segundo á la industria; así como agricultor é industrial lo son respectivamente, el labrador que produce trigo, y el fabricante que lo transforma en harina.

Cierto que el vinicuitor en pequeña escala, no ha de tener un ingeniero en su bodega, ni todos los aparatos que se requieren para una esmerada elaboración; pero puede asociarse á otros, ó adquirir guias vinícolas, tratados ó manuales como los hay al alcance de las fortunas más modestas, practicar ensayos y observar; todo lo cual puede fácilmente conseguir sin más que estar poseido de la mejor voluntad en favor de sus propios intereses.

España produce los mejores vinos del mundo en aroma, color finura y riqueza

(1) Lo que conviene es que nuestro comercio se persuada de la necesidad de enviar clases buenas que son siempre aceptadas y vendidas con facilidad y no á mal precio, ya que las ordinarias abundan por el momento en Francia y no son tan buscadas ni apetecidas, á parte los precios bajos á que tienen que cederse.

(Director de la Estación económica de España en Cette; 26 Septiembre 1895). 
alcohólica; asi lo reconocen, como no pueden menos, nuestros competidores italianos y muchos vinicultores franceses, en particular monsieur Leenhart, quien después de haber recorrido importantes comarcas vinícolas, asegura que no ha podido encontrar en los lagares un solo vino de riqueza natural menor de $1_{4}$ ó 15 grados y medio, el cual se encuentra sólamente en nuestra nacion; siendo en extremo sensible que á pesar de poseer tan preciado fruto, no haya más interés y mayor esmero para obtener vinos selectos: por lo que, y como medida de poderoso estimulo, será conveniente conceder primas á los que elaboren buenas clases de vinos (I).

(1) En la reciente Exposición de Burdeos, han obtenido los vinos españoles 2 diplomas de honor, 7 de medalla de oro, 11 de medalla de plata, 20 de medalla de bronce y 17 rilenciones honoríficas.

De los 36 expositores que concurrieron a la de Amberes, fueron agraciados 34 , y obtuvieron, gran premio, 2 diplomas de honor, 20 medallas de oro, 9 de plata y 2 de bronce.

Los anteriores datos corroboran, que á poco que se esmeren los cosecheros en el cultivo del viñedo (eligiendo buenas clases para las plantaciones é ingertos, desechando abonos perjudiciales á la calidad y valor del jugo de la uva, etc.), en la elaboración de los vinos y gestionen más la venta de los mismos en el mercado interior y exterior, que obtendrán seguramente más ventajosos resultados. 
La escandalosa Fabricación de vinos artificiales y la adulteración de los naturales hace aumentar el exceso de producción y disminuir el consumo.-Penas severas

á los infractores y expendedores de vinos artificiales ó adulterados.

Además de la exuberante producción de que hemos hablado, existe un enemigo poderoso y tangible de consecuencias más fatales que aquella, y es la escandalosa fabricación de los vinos artificiales, que muchos agiotistas confeccionan sin hacer uso de la uva, de cuyo artificio resultan composiciones y bebidas ponzoñosas, debidas no al laboratorio químico científico, sinó al taller del más diabólico alquimista, ocasionando algunas muertes accidentales y muchos casos de locura, imbecilidad y otros grandes trastornos fisiológicos, la más ruinosa competencia á los vinos naturales, y graves perjuicios á los intereses del Estado y de los Ayuntamientos.

El gran desarrollo que ha adquirido la fabricación de vinos artificiales por una parte, y por otra la adulteración de los naturales en todos los pueblos de España, particularmente en los grandes centros de población, en las zonas donde no se cosecha vino, 
y en las bodegas de algunos extranjeros que se dedican á la exportación de nuestros caldos, son causas muy poderosas de la sensible paralización que se deja sentir en las bodegas, y por tanto de que los vinos no tengan salida à ningún precio.

El mal no es quevo, existe desde hace tiempo y tiene ya hondas raices, habiéndose reconocido la necesidad de corregirle en el preámbulo del Real decreto del Ministerio de Fomento de 7 de Enero de 1887 , que dice: «Señora: El más importante de los productos naturales de nuestro suelo; el más valioso de los elementos que sirven de base á nuestro comercio exterior, se halla en la actualidad perjudicado notoriamente y amenazado aún de mucho mayor daño, por un vicio demoledor, cuyo desarrollo adquiere proporciones alarmantes.

"Diez años han bastado para que las adulteraciones de que son objeto nuestros vinos hayan traido, con el descrédito de ese rico producto, una baja de la mitad de la exportación que España hacia á Inglaterra. Si el mal no halla pronto y eficaz correctivo, toda esa inmensa riqueza que representan los dominios de la vid en la Península, ese millón y medio de hectáreas de nuestro suelo, que dán un rendimiento de más de 24 millones de hectólitros de vino por año, sufrirá enorme depreciación, y tras ella 
vendrá la ruina de extensas comarcas susceptibles de gran prosperidad".

Y sin embargo de ser susceptible de gran prosperidad, amenaza una ruina espantosa é inminente á los dos millones de hectáreas plantadas de viñedo, no habiéndose declarado todo el existente en España por no pagar aumento de contribución territorial, nj el impuesto sobre defensa de la Filoxera, no obstante ser éste tan exiguo y redundar exclusivamente en beneficio de los mismos propietarios, y en cuanto al vino por eludir el odioso impuesto de consumos.

Otras varias disposiciones ministeriales se han dictado para corregir la fabricación de los vinos artificiales y la adulteración de los naturales; todas ellas á cual más plausibles por el espiritu proteccionista que revelan en pró de tan importante ramo de nuestra riqueza pública, pero que no han dado hasta la fecha el resultado apetecido.

Es indispensable emplear medidas de rigor y de resultados prácticos contra los agiotistas y sofisticadores, que nada les importa desacreditar los mejores productos con tal de obtener ellos pingües y positivas ganancias, pues con agua, alcohol, azúcar y materias colorantes, confeccionan jarabes disfrazados con el nombre de vinos, que ocasionan tantos perjuicios á la salud pública y á los agricultores de buena fe, porque 
como aquéllos confeccionan el vino sin uva, no utilizando para la fabricación el producto natural de la tierra, pueden ofrecer los artificiales à precios mucho más bajos que los naturales.

Hay algunos vinicultores que atentando contra sus propios intereses, muchos bodegeros y la mayor parte de los vendedores al por menorque bien por eludir el pago de los derechos de consumo, (mayores en ocasiones que el precio del vino), ó llevados por el atractivo de excesivas ganancias, acostumbran á rebajar el vino con agua, que poco ó nada les cuesta, y con el aditamento de alcohol industrial, fuchsina ó cualquier otra materia colorante hacen aumentar aquel articulo de una manera considerable; y no es que tales operaciones las practiquen con todo el vino que tienen en las bodegas, almacenes ó tiendas, sino únicamente con lo que destinan en el momento á la venta; saben muy bien que de verificarlo antes, quedaria después muy blando ó rebajado, con un sabor más desagradable, y que se notaria mejor el engaño, pero siendo de la manera expresada, no se advierte al pronto y si algo se objeta después, presentan otras muestras diferentes del mismo sitio, y aun cuando se analicen no puede hallarse la adulteración, sin embargo de que existe en exageradas proporciones, no en el vino almacenado sino 
en lo que se expende al público, y aunque diferente aquella de la falsificación, son causa una y otra del descrédito de nuestros vinos en los mercados nacionales y extranjeros.

Es pues de urgente necesidad emprender una activa é interesante persecución y castigar severamente á los fabricantes y expen. dedores de vinos artificiales y adulterados, pues asi lo reclaman de consuno la salud pública, los contribuyentes de buena fe, y los intereses del Estado y de los Municipios (I).

Conveniencia de acrecentar el consumo interior en España. Medios eficaces para ello.

Después que se haya logrado,impedir la fabricación y la venta de los vinos artificiales como igualmente de los adulterados, y conseguida la elaboración de buenas clases, antes de buscar mercados extranjeros, debemos empezar por acrecentar el consumo interior, pues una vez que esté persuadido el consumidor de que ya no se elaboran ni expenden vinos artificiales, ni adulterados, renacerá la esperanza perdida, y aumentará considerablemente en nuestra nación el consumo

(1) A tal fin, detallamos-diferentes bases en la. Parte $4 .^{2}$ ó sección de Nuevos Ingresos. 
de una bebida tan sana, confortantey tan favorable á la higiene y á las buenas costumbres cual es el vino, y por este medio conseguiremos, sin duda alguna, hacer salir del retraimiento que hácia tan importante artículo se habia llevado á multitud de consumidores que en la actualidad prefieren emplear su dinero en clases selectas aunque beban menos, otros en cervezas, aguardientes y licores, y muchos, como son los menos acomodados, solo utilizan el agua por el elevado precio de aquel articulo en diferentes comarcas donde no se produce, y por la desconfianza y el temor natural á los efectos nocivos del artificio.

Para conseguir el medio de que nos ocupamos deben los vinicultores hacer cuanto esté de su parte, ya que la exportación ha de ofrecer cada dia más dificultades. Y no sirve culpar á rupturas del tratado con Francia, pues esta nación ha repuesto ya sus viñedos; las cosechas de 1893 y 1894 fueron abundantes (I) y en lo sucesivo utilizará muy poco ó nada los vinos españoles, como lo prueba el pedir constantemente para los mismos nuestros vecinos la subida de las tarifas.

Ya hemos afirmado antes que hay en España un gran exceso de producción, lo propio que sucede en casi todos los demás paises

(1) Y si la de 1895 ha sido algo escasa, no es de suponer que suceda lo propio todos los años. 
donde el suelo y clima reunen las mejores condiciones para el cultivo del viñedo; cuya afirmación no es exclusivamente nuestra, y por más que no sea necesario invocar testimonios autorizados porque todos asi lo reconocen, creemos que no estará demás transcribir las palabras del vice-presidente del importante sindicato de Viticultores de Francia (I). «Tanto más de lamentar es la situación actual de la viticultura española, cuando ésta como la francesa, están cada día más amena. zadas por el aumento de 80 millones de hectólitros realizados desde 1880 en la producción general europea, y con especialidad Italia, Hungria, Ilinia, Dalmacia, Rumania, Turquia y Grecia, sin contar que la exportación à América y Australia se vá haciendo más difícil cada día porque adquiere en aquellos paises mucha extensión el cultivo de la vid, y empienzan ya á producir vinos en cantidades casi suficientes para su consumo, además de protegerlos con derechos arancelarios tan excesivos, que equivalen á la muralla de la Ghinan.

Pues bien, ya que el cultivo de la vid se extiende de una manera tan prodigiosa en todos los paises, particularmente en una región tan dilatada como lo es la Australia aen cuyas

(1) Ir. Lacroix á la Agencia Fabra en 8 de Abril de 1893. 
diversas colonias mejora cada dia el cultivo del viñedoyla elaboración del vino para obtener excelentes productosy efectuar el embarquede los mismos en las mejores circunstancias con destino á los diversos mercados europeos y americanos" ( 1 ), antes que pensar en remitir nuestros caldos al extranjero, debemos procurar que aumente en nuestra nación el consumo de los mismos, pues conformecon el señor vice-presidente del Fomento de la Producción Nacional de Barcelona (2) aengaña á los agricultores, sobre todo á los que producen vino, quien les haga creer que pordioseando por las puertas de las naciones extranjeras van á vender bien sus vinos. Francia que era nuestro mercado, tiene ya repuestos sus viñedos y acaba de coger una cosecha que le deja sobrante. En América no se puede colocar lo que producimos. La agricultura española necesita, pues, tener el consumo en nuestra propia casa.

Y, en efecto, aumentando el consumo del vino en nuestra propia nación, pudiéramos llegar á crear, por tal medio, el mejor mercado para tan importantísimo producto.

(1) Yar book of Australia for 1892.

(2) Sallarés, meeting Bilbao, 9 Diciembre 1893. 
Medios eficaces para ello.

Para la consecución de tan interesante objeto conceptuamos que los medios más viables, prácticos y eficaces, son los siguientes:

I. Suprimir en absoluto los crecidos derechos que gravan los vinos.

2. Si las circunstancias exigieren que la supresión indicada no sea definitiva, se establecerá por lo menos con el carácter de provisional ó transitoria, hasta tanto que mejore de una manera ostensible la anómala y angustiosa situación de tan importante producto nacional.

3. En el caso de que más adelante sea absolutamente necesario gravar los vinos con algún impuesto, no excederá este, en ningún caso, del 25 por 100 del precio ó valor que, según clase, tenga en cada respectiva localidad.

$4 .^{\circ}$ Que todos los particulares, y principalmente los mismos viticultores, consideren siempre el vino como parte integra del jornal.

\section{I.}

Que la riqueza vinicola sufre una crisis espantosa, cruel, mortal de necesidad, sinó se ataja y combate el mal de una manera resuelta y enérgica no es preciso demostrarlo, 
pues por desgracia es bien notorio y á todos nos consta de un modo positivo, siendo hoy lo que preocupa total y exclusivamente á los vinicultores y à gran parte de la opinión pública de un extremo á otro de la Península; pero por lo mismo que el mal es más que grave, gravísimo, alarmante en extremo y que no aủmite la menor espera, también es necesario reconocer que la solución no puede revestir carácter liliputiense; que no puede consistir en un ligero paliativo que equivaldría á derramar un vaso de agua para aumentar el inmenso caudal del Oceano, y no serviria para otra cosa que para prolongar una situación tan excepcional é insostenible; y que por lo tanto tendrá que ser un remedio tan eficaz como urgente.

El impuesto que grava los vinos, tan detestable y molesto, es el mayor escollo, el más odioso de los obstáculos y la más sólida muralla que cierra el paso y dificulta ostensiblemente entre las clases populares el consumo de nuestra gran riqueza nacional. Es el factor más importante y que mas contribuye a la ruina de nuestra vinicultura; el lazo vigoroso que retrae, esteriliza y contiene grandes iniciativas; el dogal que oprime y axfisia; el nudo gordiano que ata, sujeta y paraliza todo tráfico y movimiento para el consumo interior; asi que las circustancias tan críticas porque atraviesa la riqueza vinícola, 
la completa supresión del referido impuesto no es ya una conveniencia, es una necesidad apremiante que se impone por razón del buen sentido y de justicia, y por lo mismo no vacilamos el proponerla en primer término.

Es también la reforma pedida con más insistencia y por rara unanimidad por los viticultores de la nación en los meetings de Valencia, Tarragona, Jumilla, etc., y en las razonadas exposiciones de todos los centros vinicolas lo primero que proponen y solicitan es la supresión del impuesto sobre los vinos, sin que pueda sustituirse por cualquier otro que grave la riqueza vinicola.

Y en efecto, no vemos en el día otro medio más eficáz, más breve y de más positivos resultados para facilitar y acrecentar el consumo en nuestra Peninsula de una bebida tan sana y confortable como es el vino, y para sacar á tan importante riqueza pública del estado de postración y decadencia, tan deplorable á que hoy se ve reducida.

Es, en las circunstancias actuales, el medio más excelente, y el que de una manera más inmediata y decisiva puede contribuir á conjurar la crisis tan honda y latente que sufre la riqueza vinicola; $y$, por tanto, ninguna otra reforma más justificada.

Todos reconocen su eficacia, y nadie duda que es un remedio soberano para solucionar 
tan árduo problema; una medida de la que esperamos los mejores resultados; la verdadera panacea que hoy puede aliviar notablemente, más que ningún otro, el gravísimo mal que sufre uno de los principales veneros de la riqueza de nuestra pátria.

Cierto que toda clase de reformas requieren meditación, y que se debe atender por igual á todos los intereses del pais; pero al que vemos oue se ahoga y se halla á punto de perecer es un deber de estrecha conciencia tenderle un cable que le libre de una muerte segura, en vez de consentir impasible que fenezca por falta de auxilio oportuno; y cuando una luz vemos que se apaga, debemos darle vida por medio del combustible necesario, antes que se apague por completo y quede en tinieblas lo que antes era luz, vida, movimiento y esperanza.

Por más que nadie con razón pueda negar la bondad de tan sentida y justificada reforma, algunos objetan que no se habrá de obtener con ella completo remedio á los males que sufre la vinicultura, porque aun suprimiendo el crecido impuesto que grava esta riqueza no habia de consumirse en nuestra nación todo el vino que la misma produce y que necesitamos además de los mercados extranjeros. Verdad es que no todo se habria de consumir en España, pero también lo es que tal medio acrecentaría el consumo 
del vino de una manera considerable, y que de los mercados extranjeros no podemos confiar mucho, por ser muy difícil conseguir tratados favorables para exportar nuestros caldos, pues Rusia (que seria buen mercado) para cuyos trigos pedimos nuevo recargo ‘habrá de concedernos aquello mismo que pretendemos se los niegue? De Alemania poco ó nada podemos esperar en virtud del fracaso que en el Senado, con aplauso unánime de los agricultores, obtuvo el tratado propuesto en aquel Imperio; además que los alemanes demuestran especial preferencia por las cervezas y aguardientes, lo propio que los suecos é ingleses.

Por otra parte y aun cuando en otras naciones se logre colocar algunas partidas, suponiendo que precisemos exportar anualmente 16 millones de hectólitros, y que no obstante las gestiones que el Gobierno y los particulares practiquen a tal fin no consigan colocar más que 8 (que no es poco, pues menos se ha exportado en los cuatro últimos años) los otros 8 millones de hectólitros restantes forzosamente habrá que consumirlos en nuestra nación ó arrojarios á la calle.

Algunos se oponen á la supresión del im. puesto que grava los vinos, fundándose en que el presupuesto de ingresos sufrirá un quebranto y que no conviene dejar indotados los servicios públicos. Claro es que no 
conviene ni se debe desatender el pago de las obligaciones generales del Estado, y por tanto, si un impuesto se suprime debe llenarse con otro el vacio que necesariamente tendrá que producir en el Erario, lo cual constituye la mayor dificultad para llegar á la supresión pero no es aquella tan insuperable que no se pueda vencer, adoptando al efecto los medios equitativos, racionales y prudentes que permitan compensar la baja que ésta ocasione; á cuyo fin nos ocupamos con el detenimiento debido en el curso de esta obra, por conceptuar que no siendo factible ni conveniente por ahora, la rebaja general de tributos, si las circunstancias aconsejan suprimir ó rebajar alguno por excepción, se debe buscar en otro ú otros la compensación debida; pero no debe olvidarse que si se abandona el cultivo de las viñas, se mermarán considerablemente los ingresos del Tesoro y muchisimos obreros quedarán sin jornal, originándose complicaciones peligrosas; y que con la supresión indicada terminará por completo el matute, y en gran parte las falsificaciones y adulteraciones de los vinosque tanto hacen aumentar la producción como disminuir el consumo; se favorecerá además al público y á los viticultores que pagan religiosamente sus respectivas cuotas contributivas y sostienen numerosos jernaleros. 


\section{II.}

Creemos haber demostrado ya, y que además estará en la conciencia de todos, que la completa supresión de tan odioso y detestable impuesto que grava los vinos es el medio de mayor eficacia, el que dará desde luego más excelentes resultados, y el que habrá de contribuir de una manera más inmediata y decisiva á conjurar la crisis tan honda y latente que sufre la riqueza vinicola, haciendo asi más llevadera la triste situación de muchísimos propietarios y de los millones de obreros que se dedican y viven del cultivo de la vid.

La vinicultura espirante no puede soportar más tiempo un impuesto tan gravoso, una carga tan abrumadora que apenas la permite moverse, siendo indudable que urge dar el primer paso con verdadera decisión y entereza para salvar á una riqueza tan principal y única que existe en algunas comarcas de la espantosa ruina que la amenaza y evitar acuerdos extremos que la desesperación pudiera hacer necesarios.

Cuatro años ya que la mayor parte de los viticultores viven á costa de sus capitales; los que tenian algunos ahorros ú otros medios de vida han podido continuar aunque con estrechez y privaciones una vida azarosa por tres ó cuatro años, pero ya de 
dia en dia se agrava más su triste situación; otros se han visto obligados por falta de compradores á sus viñas y productos, á buscar dinero á préstamo é hipotecar otras fincas, empezando asi una pendiente de perdición que habrá de conducirles á una completa ruina y que de no acudir con la mayor premura á remediar, ó aliviar siquiera, tan grave mal, el espectro del hambre ocasionará fuertes estragos en muchas regiones vitícolas, y obligará á propietarios y obreros á un esfuerzo común y supremo para conseguir la reforma que con tanta justicia y tan en vapo vienen reclamando.

En las localidades donde se logra vender el vino, suele ser á un precio tan sumamente reducido, que no compensa el pago de contribuciones y los gastos de cultivo, ni siquiera los de la vendimia, elaboración y conservación del mismo; por lo que no es de extrañar que muchas viñas no se labren, otras hasta se queden sin vendimiar y en algunos pueblos se presencie el triste espectáculo de ver á los cosecheros derramar los vinos fuera de las bodegas por no hallar quien lo compre ni caro ni barato, después de los muchos gastos y afanes que los ha costado el producirlo.

La crisis vinicola ha llegado à tal extremo de gravedad que amenaza una enorme catástrofe, y de consumarse la completa ruina de 
tan principal riqueza, á su aniquilamiento y muerte sobrevendrán conflictos y consecuencias graves para los viticultores y jornaleros: en primer término, pero mas adelante recaerán también fatal y necesariamente sobre la nación entera.

El impuesto de consumos es el que á un artículo de primera necesidad y á una bebida higiénica y confortable como es el vino, le convierte en artículo de lujo, particularmente en las grandes poblaciones, en las cuales el repetido impuesto es tres y aun cuatro veces mayor que el del precio del vino, por lo cual á las clases poco acomodadas, que constituyen la inmensa mayoria de los habitantes de aquellas, sé las obliga, por tal medio á abstenerse de tan sana y tónica bebida; ó á limitar considerablemente el consumo de la misma. Los agiotistas, por eludir el pago del impuesto, confeccionan mistelas y bebidas ponzoñosas, en perjuicio evidente de la salubridad pública y de los vendedores de buena fe; de todo lo cual resulta que el consumo del vino se reduce á una parte sumamente insignificante; siendo indudable que la reforma mencionada constituye una necesidad suprema.

Cierto que á todas las manifestaciones de riqueza se las debe conceder protección, igual á unas que á otras; pero por lo mismo que ningún producto se halla gravado con un impuesto tan exorbitante como el vino, y ser 
el que esta en más visible decadencia y ruina, es también el que reclama auxilio con más justicia y que debe prestarse con la premura que la gravedad suma del mal requiere y con preferencia à todas las demás riquezas.

Si más adelante, en los años sucesivos, mejorase de una manera ostensible tan importantísima rama de nuestra producción nacioual (por más que es difícil regenerar un organismo anémico y devolver la feracidad á un terreno esquilmado) y las circunstancias exigieren la adopción de algún gravamen, impóngase pues entónces en la parte que equitativa y proporciona damente corresponda, si se estimare que ningún elcmento de riqueza debe ser de mejor condición que otro; pero atiéndase siempre con preferencia al más débil y necesitado, aplicando, con oportunidad el verdadero remedio; sepárese la compuerta que detiene el agua fertilizante que puede devolver la sávia y lozania á muchas comarcas ya casi agostadas por una larga sequia, tiéndase con presteza un cable al náufrago que se ahoga, y acúdase con premura à apagar el edificio que arde $y$ amenaza con sus imponentes llamas convertirlo todo en cenizas.

La supresión del impuesto que grava los vinos es una reforma que urge acometerla con verdadera decisión y entereza; aun cuando sea solamente con el carácter de 
provisional ó transitoria, á fin de que tan interesantísimo ramo de nuestra riqueza pública mejore con rapidez y se eviten los muchos y graves males que sobrevendrán necesariamente, de continuar en situación tan lamentable y excepcional.

Es, pues, necesario adaptarse á los tiempos y à lo que exigen las circunstancias y reconocer de buen grado que la indicada reforma es la más precisa, la más eficaz y de mejores resultados para el desarrollo del gran mercado interior, único del que en el dia podemos esperar más breves y más copiosos frutos.

Es, á no dudarlo, más práctico y más indispensable aún que la de suprimir la contribución que los propietarios satisfacen por sus. viñedos, es una cuestión de capital interés, un problema de vida ó muerte para nuestra riqueza vinicola; y por tanto, medida salvadora, apremiante en extremo, que se impone por la razón, la lógica, la justicia, y por la ley de la necesidad, es la de suprimir en absoluto el impuesto de Consumos sobre los vinos.

\section{III.}

El medio más radical, de más breves y mejores resultados para aumentar en nuestra nación el consumo de los vinos, es la completa 
supresión del impuesto que grava los mismos, según queda expresado, pero si debido a este medio, ó á cualquier otra circunstancia mejorase más adelante tan importante ramo de riqueza pública y pudiera soportar algún gravámen ó impuesto, entendemos que en todo caso deberá tenerse en cuenta y adoptar como base para ello el valor ó precio del vino; principio fundamental sobre el que debe apoyarse toda imposición ó tributo, con lo cual no se daría el caso tan absurdo, altamente injusto y desproporcionado de que mientras el valor del vino es en diversas cómarcas de 2 á 4 reales el cántaro de 16 ' 13 litros, haya que pagar en algunas poblaciones importantes, por impuestos de consumo 14 y 16 reales.

El trigo, cuyo precio excede en la actualidad ( $\mathrm{I}$, de 32 reales la fanega de 94 libras ó $43^{6} 240$ kilógramos, no llega siquiera á 2 reales lo que paga por impuesto de consumo; y en igual ó más reducida proporción resultan gravados los demás cereales, las legumbres, los aceites y las carnes. Unicamente el vino es el que resulta gravado con un impuesto que excede en algunos casos del 300 y aun del 400 por Ioo de su valor,

(1) Pues cuando se publicó la Tarifa vigente de Consunios, era algo más elevado. 
siendo asi que hoy necesita mayor protec. ción que todas las demás riquezas.

Sabido és, que cuando se publicó la Tarifa general de 16 de Junio de 1885 , para el impuesto de Consumos, por virtud de lo preceptuado en el art. $30^{\circ}$ de la Ley de la propia fecha, el precio del vino era el de 20 á 24 reales el cántaro (ó sea 6 ó 7 veces más que ahora), y el mismo con pequeña diferencia cuando se aprobó y publicó el reglamento provisional de 2 I de Junio de 1889 que continúa vigente; pero de entónces acá las circunstancias desgraciadamente han variado tanto que no es posible que la riqueza vinicola continúe más tiempo pagando un impuesto tan desproporcionado y exorbitante.

Así pues, el Gobierno por razón de equidad y justicia, y como de necesidad imperiosa, debe apresurarse a llevar á la práctica la indicada reforma, y de gravar en lo sucesivo con algún impuesto el vino que se destine á la venta, si es que á tan importante riqueza se la llega á colocar en otra situación más halagüeña y floreciente, convendrá que lo sea con relación à su valor, à cuya base, principio y raiz deberá sujetarse necesariamente el tributo ó gravamen, pero sin que en ningún caso exceda del 25 por 100, que según clase tenga en cada localidad, pues tampoco es equitativo, ni razonable que los exquisitos vinos de Jeréz, Málaga y Cariñena, 
ó los añejos de ia Nava del Rey, Rueda, etc., que se venden á más de 100 reales el cántaro, paguen por derechos de consumo lo mismo que los comunes ú ordinarios de otras zonas, que no valen (cuando se logra la venta) más de 4 ó 5 reales el cántaro; ni los que en igualdad y aun inferioridad de clases cuyas bodegas se encuentran más próximas de los centros consumidores ó exportadores, si por esta coincidencia de la fortuna, venden à doble y aun á triple precio que los que se hallan à distancias considerables; porque sería establecer, como ahora sucede, un privilegio injusto é irritante. El precio de cada localidad debe ser la base y principio fundamental en que se apoye y descanse el precitado impuesto.

La ley Municipal vigente, en su espiritu elevado y previsor, establece en la regla I. del art. I 39 que "las Tarifas no excederán en ningún caso del 25 por roo del precio medio del articulo en la localidad respectiva, según su clase». De manera que por necesaria y justificada que sea la imposición de cualquier arbitrio, los Ayuntamientos no podrán traspasar jamás el referido límite de 25 por roo del valor de cada especie; por lo que no vemos razón alguna para que exceda en la actualidad del 300 y 400 por $100 \mathrm{con}$ los derechos del Tesoro público, precisamente en los vinos, cuya riqueza se halla en muy 
visible decadencia y ruina (I) siendo asi que otras industrias más florecientes, y las demás especies gravadas con dicho impuesto no llega ninguna (á excepción de la sal común) al limite expresado.

Asi, pues, de no suprimir por completo el impuesto que grava los vinos, (lo cual es más conveniente y preciso que rebajar aunque sea un 50 ó un 75 por 100 los derechos del Tesoro y los recargos municipales reunidos), lo más práctico, racional y positivo es acordar que los derechos por impuesto de Consumo no excedan por ningún concepto del 25 por 100 del precio ó valor del vino, según clase, en cada localidad respectiva (2).

(1) A pesar de rque en Francia el impuesto de Consumos es mucho menos gravoso que en España, y que casi no afecta á la producción nacional, IIr. Ribot ha propuesto se supriman los diversos derechos sobre los vinos en aquella nación, sustituyéndolos por un derecho único de consumo, de manera que ni aun en las grandes poblaciones exceda de 4 francos el hectólitro. En España, ya es sabido que en las poblaciones de 6." clase, asciende el susodicho impuesto, con el recargo municipal á 25 pesetas el hectólitro.

(2) Conforme propuso el Sr. La Torre al Congreso de Diputados en Il de Junio de 1895, en su plansible deseo de favorecer la riqueza vinicola y como medio le obviar las dificultades que algunos presentabaná la supresión y rebaja del impuesto que grava los vinos. 
Para el adeudo, entendemos que será suficiente que los cosecheros, industriales ó vendedores situados en el interior de las poblaciones donde existan fielatos exteriores, presenten en la Alcaldia respectiva una relación en la que expresen, bajo su más estrecha responsabilidad, la cantidad de vino que se proponen destinar á la venta, clase y precio del mismo.

Lo que se destine á la venta pública en sitio distinto del de la producción y que deba adeudarse, por consiguiente, en otro ú otros términos municipales, presentarán los compradores ó conductores un certificado expedido por el vendedor, en el que conste el precio y clase del vino, y además otro certificado del Alcalde en el que se acredite el precio medio de cada clase en la localidad y fecha respectiva.

Los que faltaren á la verdad comprando ó vendiendo á mayor precio del señalado en los certificados exhibidos, incurrirán en la multa de 50 pesetas por cada hectólitro, y doble si fueren reincidentes, con pérdida además del vino que expendieren ó fcondujeren, ú otra multa equivalente al valor del mismo si la defraudación fuere descubierta después de su expedición ó consumo, cuyo importe se distribuirá por partes iguales entre los que descubran el fraude, ya sean empleados de resguardo ó simples particulares; 
siendo pública la acción para denunciar las infracciones y abusos que sobre el particular se comentan. El que reincida por tercera vez, además de las multas expresadas, será entregado á los Tribunales ordinarios, para que le impongan la responsabilidad establecida en el art. 547 del Código penal. Si algún Alcalde faltare á la verdad en los certificados que expida, incurrirá también en las propias multas y responsabilidades establecidas para los defraudadores.

\section{IV.}

Otro medio tan sencillo como eficaz para acrecentar el consumo interior, y que más que al Estado corresponde á los mismos cosecheros y particulares, consiste en que el vino sea considerado siempre como parte integra del jornal.

Muchos cosecheros prefieren, con grande error suyo, elevar el precio de los jornales por no dar vino, de donde resulta también una sensible disminución en el consumo de dicho artículo.

Los jornaleros, en su inmensa mayoria, no llevan al campo más bebida que el agua; trabajan todos los dias de la semana sin probar el vino, y únicamente los Domingos y dias festivos los que tienen algún pequeño ahorro suelen tomar, no en su casa, sino en 
las cantinas ó tabernas, medio litro ó cuando más uno de vino. Como á muchos los falta la alimentación suficiente y un buen método higiénico, y más que todo la costumbre de utilizar diariamente tan sana é importante bebida nutritiva, unido á esto la mayor ó menor adulteración que contengan los líquidos, resulta en tales casos con la mayor facilidad la embriaguez, y lo que es mucho más grave las pendencias y los crímenes.

Muy raro es el día festivo que tanto en los grandes centros de población como en los pueblos no hay que lamentar algún caso de la indole citada. A las autoridades locales, juzgados de guardia, agentes de órden público, guardias municipales y serenos, se les obliga en tales dias á ejercitar sus respectivas funciones por la circunstancia mencionada, debida á la que aumentan su población respectiva las casas de socorro, cárceles y hospitales.

Cierto que más cómodo que dar vino, es para los propietarios pagar sólamente en metálico, pero también lo es que resulta más perjudicial, pues mejor que de la manera expresada seria, a no dudarlo, que éstos utilizasen tan confortable bebida á diario con método durante el trabajo y con la familia en el hogar doméstico.

Asi conseguirian los amos y principalmente los cosecheros cinco fines á cual más 
importantes: I. $^{\circ}$ Dar salida á sus productos; 2. Morigerar las costumbres; 3. Evitar excesos y abusos alejando de las cantinas á sus dependientes; $40^{\circ}$ Que éstos beban vino puro. Y $50^{\circ}$ Que se hallen mejor alimentados; circunstancia indispensable para que puedan sobrellevar las pesadas tareas del trabajo.

Tampoco, ni aun en circunstancias excepcionales (que rara vez se presentan) los cosecheros y expendedores de vinos, deben elevar demasiado el precio de los mismos, sino conformarse unos y otros con un precio suficientemente remunerador, que es el que debe servirlos de norma, para no convertir en artículo de lujo el que es de primera necesidad, é imponer, por tal medio, la abstención de su consumo á las clases menos acomodadas.

La costumbre de muchos padres de familia de proscribir á sus hijos en la mesa una bebida tan sana hasta que llegan á la mayor edad, nos parece censurable y que seguramente la ciencia médica reprueba, hoy que por desgracia tanto abundan los estados anémicos y raquíticos, para cuya reconstitución y desarrollo físico (y aun moral) constituyen un factor importante los buenos vinos (I).

(1) Lo propio decimos de la regla ó costumbre establecida [en la mayor parte de los colegios de 
Los dueños de fabricas, talleres, minas, y empresarios ó contratistas de obras públicas y particulares, si abonasen en producto de la vid una parte de los jornales ó haberes de sus dependientes respectivos, seria una medida altamente plausible, digna de gratitud por parte de los viticultores y aun de los mismos obreros, y muy en particular de mención honorifica por parte del Gobierno.

Aun cuando no aparezca tan meritoria la adopción de tal medida en los viticultores, pues debieran ser los más solícitos en establecerla, por la mucha conveniencia que habria de reportar á sus intereses y para no darse el triste espectáculo de que mientras las bodegas se hallan atestadas de vino, carezcan de ello las personas que diariamente derraman el sudor de su frente en el cultivo de la vid, sin embargo opinamos que también se haga en su favor la propia concesión,

alumnos internos y medio pensionistas respecto de la limitación á los días festivos del uso de una copita (de un doble decilitro próximamente) de vino para cada comida, y cuya previsora medida debiera hacerse extensiva á todos los demás dias del año.

Si los recursos del Tesoro permitiesen aumentar el escaso haber que disfruta el soldado, no vacilariamos en aconsejar se distribuyera entre la tropa una cantidad morigerada de vino potable, á la vez que el pan y las viandas, como complemento de una buena alimentación. 
y muy principalmente de los labradores, industriales y de cuantas personas contribuyan á acrecentar el consumo interior por el medio propuesto (I).

(1) Nada más lejos de nuestro ánimo que abrigar pretensiones didácticas de ningún género; pero como pudiera parecer, á primera vista, una tarea muy difícil y gravosa la concesión de tal gracia al número tan considerable de personas que seguramente habria de considerarse con derecho á obtener la misma, creemos que no estará de más consignar que, en nuestro concepto, todo podría reducirse á formar los Ayuntamiertos cada diez años un padrón con los nombres de los interesados, el cual deberá rectificarse todos los años intermedios con las alteraciones que de oficio $\delta$ á instancia de parte fueren procedentes, y previa exposición al público del mismo documento y apéndices respectivos, para oir de agravios, remitirle á la Diputación provincial de idéntica manera que las listas electorales. Cada Diputación provincial, en vista de los datos recibidos y resueltas las reclamaciones presentadas, proceder á refundir en un sólo documento los padrones ó apéndices de los Ayuntamientos de la provincia y elevarle al Ministerio de Fomento y aprobado ó corregido que fuere, publicar por suplemento, en los Boletines Oficiales los nombres y domicilios de las personas, sociedades ó compañías á quienes se hubiere otorgado la gracia expresada. 
Mercados extranjeros.-

Apesar de los medios propuestos, es de necesidad, por ahora, abrir nuevos mercados. y consolidar los antiguos. - Sitios á tal fin indicados.-Primas á los que exporten vinos en proporción á la cantidad y clase del producto.- -Sindicatos de exportación, estaciones enotécnicas, agencias consulares, $\mathrm{y}$ exposiciones.

Una vez que se haya logrado acrecentar el consumo interior, habremos adelantado mucho en pro de la riqueza vinícola, por más que no lo suficiente, debido al considerable exceso de producción, y por lo tanto resultará un sobrante de no escaso valor, al que necesariamente habrá de procurarse darle fácil salida, y à ser posible ventajosa colocación en los mercados extranjeros.

Suponiendo que cada año se consuman en España 16 millones de hectólitros de vino, (I) y que abierto por el medio anteriormente propuesto el primer mercado cerrado á los vinos, que es nuestra nación, se pudiera acrecentar el consumo del mismo artículo

(1) La falta de datos exactos acerca de la producción y consumo en cada localidad, nos obliga á proceder por cálculo pradencial y aproximado.

Crisis agrícola. 
en 8 millones más, resultará que necesitamos acudir á los mercados extranjeros para dar colocación á los 7 ú 8 millones que, por término medio, han de quedar sobrantes todos los años. De manera que para conjurar la crisis tan honda como sensible que en la actualidad sufre la riqueza vinicola, fuente la más susceptible de prosperidad en algunas comarcas, no es posible prescindir por ahora, sino que es de necesidad absoluta como uno de los medios más eficaces á tan importante fin, el de abrir nuevos mercados extranjeros, y consolidar los antiguos.

Y ¿hácia donde dirigiremos nuestras miradas? Oscuro se presenta el horizonte; densas nubes se divisan en lontananza, y á ruestra vista no se ofrece otra cosa que dudas, vacilaciones y zozobras; pero por lo mismo que son muchos los obstáculos que se oponen en el exterior al desenvolviento de nuestra producción nacional, es necesaria mayor fuerza de voluntad para vencerlos.

Si la buena elaboración de vinos habrá de reportar grandes ventajas para acrecentar el consumo interior, no pequeñas se obtendrán para facilitar la venta de los mismos en los mercados extranjeros, porque las clases medianas no son buscadas, ni pueden resistir largos transportes, y no sirven para otra cosa que para su propio descrédito, y el de todas las demás de la nación de que proceden. 
El mayor esmero en la elaboración y las facilidades para el transporte ha aumentado de una manera considerable la exportación de vinos italianos à Francia, Austria, Alemania, y á diferentes repúblicas americanas. Con respecto á los aguardientes y licores se ha llegado en España á un estado de adelanto para resistir toda competencia (r); mas no asi con los vinos, pues son pocas las clases que pueden rivalizar con las de Italia, y muchas las que no reunen condiciones para ser exportadas á países lejanos.

Para competir en Francia con los vinos italianos tenemos la ventaja del menor recorrido, la diferencia de tarifa y la mejor calidad del fruto, circunstancias poderosísimas que tanto nos favorecen, y que á poco que se

(1) La importante casa de los Sres. Jiménez y Lamothe después de haber alcanzado en la Exposición de Chicago el premio de Excelencia (que es el más importante que para cada industria se concedió en este grall certámen nacional), por la pureza y finura de sus Cognacs $A d$ Brandy, extraidos del vino puro, ha obtenido también en la reciente Exposición regional de Málaga el Diploma de honor por sus aguardientes estilo Cognac elaborados en sus grandiosas destilerias de Málaga y Manzanares, instaladas por el mejor sistema conocido de Francia; y cuyos selectos productos pueden competir en las marcas más acreditadas del extranjero. 
esmere la elaboración no strá dificil el triunfo de nuestros caldos en aquella nación. Pero si la importancia de una buena elaboración es indudable, tambièn lo es la de buscar al consumidor $y$ ofrecerle los productos en condiciones aceptables, pues no. basta elaborar buenos vinos, si éstos no. son conocidos de las personas que se dedican á la compra y exportación de los mismos.

Antes teniamos el mercado de Francia que consumia todo el vino sobrante en España y parte del de otros paises, pues desde el tratado de 1877 empezó á desarrollarse, habiendo alcanzado sus mayores cifras cuando la filoxera devastó los viñedos de aquella nación; pero esta circunstancia meramente accidental y transitoria tenia que cesar, como en efecto ya ha sucedido, desde el momento que los franceses han logrado la reposición de sus viñedos, á lo que obedece sin duda alguna, como consecuencia natural é inmediata, más que á la elevación de tarifas y á la terminación de tratados, el descenso tan considerable que todos lamentamos en la venta de nuestros vinos, base principal hasta hace muy pocos años de nuestro comercio exterior.

Sin embargo de tan poderosa circunstancia, no conviene por ahora prescindir de tan importante mercado, y es preciso colocarle 
en primer lugar entre los extranjeros (I), puesto que Francia necesita de nuestros caldos para alimentar su creciente y sin igual industria de vinos (2) los que después de modificados exporta á otros paises, incluso el nuestro, al que devuelve parte de los mismos

(1) Según los datos que hemos consultado, resulta que España ha exportado á Francia:

En los siete primeros meses de 1892. 3.552.268 hects. En igual época de. . . . 1893. 2.558.554 " En idem de. . . . . . . 1894. 1.519.852 » En idem de. . . . . . .1895. 1.814.236 »

Resto de Europa, Africa, Asia, América y Oceanía: En los siete primeros meses de 1892. 0.777.107 hects. En igual época. . . . . . 1893. 0.894.756 , En idem idem.. •. . . . 1894. 0.980 .875 » En idem idem.. . . . . . 1895. 1.074.286 ,

(2) Y más hasta tanto que se verifique la vendimia de 1896 en razón á que la de 1895 ha sido algo escasa en aquel país vecíno (unos 12 millones de hectólitros menos que la de 1894, y 23 millones de hectólitros, también menos que la de 1893); las buenas disposiciones que parece existen para concertar un modus vivendi entre ambas naciones hasta tanto que se pueda llegar a un tratado definitivo: que la escasez de una mercancia con relación á la necesidad de su consumo, hace acudir al punto donde la misma abunda; y á que en Italia, Tunez, Turquía y Grecia la cosecha última fué algo reducida; lo que conviene tener en cuenta por si estas circunstancias unidas á la ley sobre el Coupage pudiera facilitar algo la exportación de nuestros vinos. 
vinos que salieron antes, si bien ya calificados con distintos nombres.

Pero además del mercado francés, de suyo variable, es necesario pensar en los de otras naciones, á fin de no tener que acudir con súplicas al exigente, y puesto que Francia dentro de muy poco tiempo (I) producirá vino bastante para no tener necesidad de recurrir á España é Italia, y entónces cerrará por completo sus mercados à los vinos extranjeros.

Austria, Inglaterra, Suecia, Bélgica y otras naciones en las que está muy generalizado el consumo de la cerveza, y á cuyos mercados si se llevaran buenos vinos sería muy probable obtener de sú vienta positivos resultados.

El Japón y demás paises del Asia oriental que $v$ an adoptando paulatinamente los gustos y las costumbres de Europa, pudieran llegar á constituir buenos mercados para los vinos españoles; pero á donde principalmente deben dirigir su acción nuestros gobernantes, es á las repúblicas americanas en las que los vinos procedentes de España tienen su porve. nir por ser los grandes mercados consumidores de los productos españoles, en particular

(1) Como en Vayo de 1893 decia e! ultraproteccio-1 nista Mr. Froin. 
los paises hermanos do hablan el mismo idioma que nosotros, y en ellos se hallan tan arraigadas nuestras costumbres y ser descendientes de españoles la inmensa mayoria de los que pueblan tan ricas y amenas regiones.

La isla de Cuba y Puerto Rico son también buenos mercados para los vinos españo. les, y lo serán á no dudarlo mucho mejores si el Gobierno rebaja los crecidos derechos de Aduana, por lo menos á lo que se paga en otras naciones europeas; pues es verdaderamente inconcebible que pidamos reducción de derechos para facilitar la salida de nuestros vinos á los mercados extranjeros, y paguemos mucho más en nuestra propia casa. Por otra parte, es preciso no olvidar que las provincias ultramarinas son nuestras hermanas y nutren á la metrópoli España, y que por lo tanto, son igualmente dignas de protección por parte de todos los buenos españoles, y para evitar además motivos y pretextos de luchas sangrientas en aquellos pedazos lejanos del territorio pátrio.

Los vinicultores á su vez, además de esmerarse por elaborar buenas clases, deberán procurar también adquirirbuenes relaciones comerciales para la más fácil y ventajosa colocación de sus productos en los mercados extranjeros, aun cuando al pronto tengan que luchar con algunos obstáculos. «En resumen, 
la viticultura española sufre en la actualidad una verdadera crisis. Para conjurarla es preciso servir directamente los mercados extranjeros. Hoy dia, tal como se fabrican los vinos en España, es imposible su venta fuera de ella, por la falta de tipos. Hay que reformar la fabricación y establecer agentes intermediarios ó sindicatos de cosecheros. Es preciso que los corredores vayan á todas partes, no perdonando medio alguno por dificil, ni despreciando ninguno por nimio, para acreditar y propagar las marcas á ellos contiadas (I).

Por más que el adquirir buenas relaciones en los mercados nacionales y extranjeros no sea muy dificil, y mucho menos imposible, no deja de ser meritorio, y tambien ventajoso para la producción nacional; y por lo tanto conceptuamos procedente que, de la propia manera que Alemania ha dominado una crisis azucarera protegiendo á los cultivadores de remolacha, y abonando una prima á los exportadores de azúcar, que España conceda primas á los que de la misma exporten sus vinos, en proporción á la cantidad y clase del producto.

Además será conveniente crear sindicatos de exportación protegidos, $y$, si necesario

(1) E. Martin Gac. Agrícola 16 Enero 1893. 
fuere, subvencionados por el Estado. Establecer estaciones enotécnicas y Agencias Consulares en Francia, Inglaterra, Estados Unidos, República Argentina, en el Asia Oriental y en los demás paises que puedan ofrecer éxito favorable, para la difusión y conocimiento de nuestros vinos, y con igual objeto desig. nar viajantes y corredores, para que, á imitación de Italia, se encarguen de hacer propaganda, estudien las necesidades de los mercados, faciliten la venta de nuestros productos para la mejor colocación de los mismos; y vigilen con asidua constancia à fin de que no se expendan vinos artificiales ni adulterados con el nombre de españoles.

Celebrar las exposiciones nacionales y regionales que fueren necesarias (I); y adoptar cualquier otro medio que tienda á favorecer la riqueza vinicola; puesto que de no hacerlo asi multitud de familias habrán de quedar sin trabajo, los viticultores tendrán que arrancar las cepas, despedir á los obreros y emigrar con éstos, ó exponerse á perecer por falta de recursos, y sobrevendrán necesariamente sus naturales consecuencias.

La situación tan crítica y excepcional porque atraviesa la riqueza vinicola, reclama el auxilio y protección de los Poderes públicos con el ánsia, con la necesidad y con la

(1) Y que mencionamos en la Parte 3.॰ 
justicia que la demanda el náufrago que se encuentra en alta mar asido a una débil astilla, cansado de luchar en vano contra las olas, y ya casi extinguidas sus fuerzas y próximo á perecer divisa, no ya en lontananza, en cuyo caso su extrema debilidad no le permitiria esperar el auxilio que pudiera prestarle, sino cerca, muy cerca de sí la ansiada nave que puede librarle de una muerte segura y aciaga.

¡Qué satisfacción tan inmensa librar de la muerte al que se halla en peligro de perecer! y iqué responsabilidad tan grande ante Dios y el mundo para el que pudiendo evitarlo á tiempo no lo hace, y con su indiferencia glacial, injustificada y censurable consiente que aquél sucumba! Para éste las más execrables abominaciones; así como los más entusiastas y lisonjeros plácemes, gratitud y reconocimiento eterno para el primero, y la satisfacción tan intima, grata y placentera que habrá de experimentar por su proceder tan correcto y elevado.

Esto último esperamos para el Gobierno y demás hombres de valía que sin dilación lleven á la práctica los medios propuestos, todos realizables, con los cuales abrigamos la confianza que habrá de mejorar ostensiblemente la aflictiva situación de tan importantísimo ramo de riqueza pública; pues cohibidas las nuevas plantaciones; ubtenida la 
buena elaboración de clases; sin la escandalosa fabricación de vinos artificiales, y la adulteración de los naturales; con penas severas á los fabricantes y expendedores de los mismos; premios á los que garanticen y exporten los productos; conseguida la supresión de los crecidos derechos que gravan los vinos; obtenido en su consumo un aumento considerable en España, y el remanente que encuentre colocación en el extranjero, la riqueza vinicola que se halla hoy en un estado de postración tan crítico, excepcional y lamentable, como no se ha conocido jamàs, confiamos sin ser optimistas, que habria de florecer como la rosa en primavera, después de los rigorosos frios del invierno; pero si continúa sin la protección decidida que tanto necesita, entónces sobrevendrán á no dudarlo, inconvenientes y conflictos graves que todos debemos procurar evitar. 



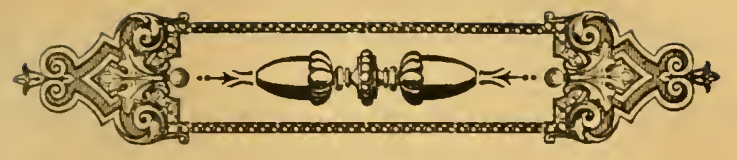

\section{CAPITULO II.}

\section{De los cereales y sus harinas.}

1. El cultivo de los cereales es insustituible, y el que ofrece más seguro porvenir.

2. El aumento en la producción de cereales es un factor importante para que el consumo del pan de trigo sea mayor en España, y el mejor medio de evitar importantes arribos á nuestras costas.

3. La baratura de los cereales -Legumbres y otros diversos productos.

4. Modificar las Tarifas para el transporte de productos agricolas sobre la base de percepción por unidad de tonelada y kilómetro de recorrido.Compensación á las Compañias ferroviarias.

5. Prohibición de importar los productos extranjeros que no sean necesarios. - Elevar prudencialmente el arancel para los que siéndolo, se importen en España y sus posesiones de Ultramar.-Vigilancia especial en las costas y fronteras.

6. Abrir y consolidar los mercados de Cuba, Puerto Rico, y Filipinas, para los trigos y harinas nacionales.

El trigo con sus variedades constituye la más importante base de la alimentación del hombre en todo el mundo; y es la primera 
producción entre todas las que constituyen la riqueza de nuestro pais (por lo cual algunos denominan al trigo el rey de los cereales); siendo el pan de cada día, no solamente un artículo de primera, sino de absoluta é imprescindible necesidad en la especie humana.

Además del trigo, el ramo de cereales comprende el centeno, la cebada, la avena, el arroz, el maiz, el mijo, el panizo, el sorgo, la zahina, etc., que además de los muchos usos á que se aplican, sirven también para alimento de los ganados, y sostienen infinidad de industrias; por lo cual preciso es reconocer que la producción de cereales es la más importante de España.

La situación de la clase labradora, no es tan satisfactoria y halagüeña como fuera de desear, debido à la depreciación de sus productos, y á lo reducidas que ván siendo las cosechas; pero afortunadamente la producción de cereales no se encuentra en el caso tan desesperado que la de los vinos.

El cultivo de cereales es insustituible $y$ el que ofrece más seguro porvenir.

El importante ramo de cereales, aunque en la actualidad en vez de ganancias casi no ofrece más que pérdidas, es el que brinda por ahora con un porvenir más lisonjero $y$ 
de más positivas ventajas, sin que se pueda prescindir de un articulo de consumo tan necesario para la vida del hombre.

Extensos terrenos destinados a cereales han sido plantados de viñedo (con grande error de los que tal hicieron, como creemos haber demostrado en el capitulo anterior), cuya circunstancia ha hecho disminuir algo la cosecha de cereales, en particular la del centeno; las muchas dehesas y demás terrenos roturados (en perjuicio de la ganaderia), han perdido de hecho su fertilidad por falta de abonos y del esmerado cultivo que necesitan, por lo que cada día se acentúa más el descenso de la producción. Esto mismo ocurre en algunas comarcas de Rusia (I), y en diversos territorios antes virgenes y feraces de los Estados-Unidos (2), en los cuales el cultivo llega ya hasta la zona árida de las montañas, siendo imposible cultivar más, y la mitad de superficie total no produce ya trigo, ni puede producirlo.

(1) Cuyo colosal imperio ha sido el que ha importado en nuestra nación mayores cantidades de trigo; pues excelde de 600 millones de hectólitros los que produce anualmente en cereales, más aún que los Estados-Unidos.

(2) Que producian ordinariamente 15 o 20 por cada uno de sembradura, mientras que España no produce más que 7 ú 8 por término medio. 
Así, y con referencia al testimonio de numerosos publicistas, lo asegura la subcomisión I. ${ }^{2}$ en su luminoso dictamen, acerca de las causas de la crisis de los cereales y legumbres, y medidas que pudieran remediarla, añadiendo: "De estos datos, relativos á Rusia, Estados-Unidos é Italia, dedúcese, pues, que no es pavoroso el porvenir respecto á la concurrencia extranjera, y que lejos de abrigar nosotros temores de que se impondrá á nuestra producción para aniquilarla, debemos pensar en sostener y aumentar la nuestra, porque cada dia es mayor el consumo en el mundo entero, y si hoy cuesta trabajo atender á sus imperiosas demandas en España, y fuera de España sobre todo, resultará que esos paises grandes productores, en los que cada día será más cara la producción, no podrán satisfacer cumplidamente los pedidos en la mayor parte de los años en que por desgracia para Europa son deficientes las cosechas (I)).

Aún cuando tales circunstancias obligùen á dichos Estados á convertir el cultivo extensivo en intensivo, los gastos serán mayores, que harán elevar el precio del producto y dificultar el surtido á Europa (2).

(l) Tom. I, parte 2.a

(2) Según la Gazette de Cologne, la situación general de los labradores está á punto de mejorar de un modo sensible. En Rusia las sembraduras de trigo 
El consumo del trigo es cada vez mayor en todos los paises, aun en aquellas comarcas en que antes hacian uso del pan de la harina de maiz principalmente.

Además, asi como la producción de vino resulta excesiva y necesitamos, por lo tanto exportar una parte muy considerable de la misma, no sucede lo propio con la de cereales, cuya producción no es hoy todavia suficiente para satisfacer las necesidades del consumo,

han debido de disminuir en 864.000 hectáreas; en Rumania habrán sembrado sobre un millón de hectáreas menos; y en los Estados-Unidos, el cultivo ha disminuido en los últimos años en 4 millones de acres. Por lo que se refiere al Australia del Sud, la cosecha ha descendido á lo menos en nna mitad, de tal suerte que, no queda más que sobre 1.600 .000 hectólitros en disposición de ser destinados á la exportación, en lagar de 2.400.000 hectólitros que antes exportaba.

Además el Dr. Wemer profesor de la Escuela Superior deAgricultura de Berlín, asegura que la cría del ganado en los Estados-Unidos adquiere un desarrollo extraordinario. En $18 \%$ habia 8.935 .000 vacas de leche, cifra que se transformó en 1892 en 16.416.000. El número de las otras cabezas de ganado, se elevaba á 14.885 .000 y 37.651.000 respectivamente; por lo que supone el referido profesor que en un espacio de tiempo no lejano cesará la exportación de trigo americano, aumentando por el contrario la importación de los productos de origen animal; cayas circunstancias habrán de influir notablemente para mejorar la situación de nuestros agricultores. 
la siembra y exportación colonial, sino que precisamos por tal circunstancia de los trigos extranjeros, particularmente en los años de mala cosecha; como lo prueban las cantidades tan enormes que del mismo producto llegan de otros paises á nuestras costas y fronteras, y que exceden con mucho à lo poco que nosotros exportamos (I).

Los cereales ya es sabido que no tienen los muchos inconvenientes que los vinos, pues éstos además de no tener salida á ningún precio, como sucede en ocasiones en algunas zonas productoras, se agrian y descomponen con facilidad y precisan envás ó tonelaje delicado. El trigo, lejos de tener mermas, como el vino, aumenta en volúmen en las paneras ó almacenes bien acondicionados, y cuidandolo, se conserva largo tiempo sin

(1) Según los datos que hemos reunido, resulta que dnrante el año 1894 entraron en España pagando derechos:

Trigos. • • 424.825 .627 kilógramos.
Harinas. . • 7.525 .822

Y se exportaron en el mismo año:

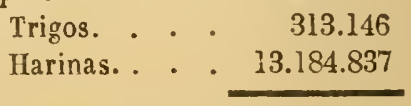

0 lo que viene á ser lo mismo;

Importado de trigo y harina. . 432 millnes de kilógs. Exportado de id.

id.

13 จ

》 
perder la virtud alimenticia y germinativa, con la ventaja de poderlo almacenar fácilmente y venderlo más caro ó más barato tan luego como se desee, en el mercado, en casa, y hasta en la era ó sitio donde se hace la trilla y limpia de cereales.

Del vino dicen muchos que tiene un buen fiador, que es el agua, con cuya expresión tan gráfica y expresiva dán á entender que à falta del vino pueden utilizar el agua, mientras que sin el pan de mejor ó peor calidad nadie pasa, y las clases menos acomodadas son las que hacen mayor consumo del mismo en razón á que carecen de otros articulos necesarios para la alimentación; así que no es posible, ni conveniente prescindir de tan valiosa producción.

Podrán variar más adelante, las circunstancias, como ha sucedido con los vinos (aunque el caso es diferente), mas por hoy no parece lo probable.

El aumento en la producción de cereales es un factor importante para que los productos puedan resultar baratos, y

el mejor medio de evitar importantes arribos á nuestras costas.

El propósito de los americanos de producir barato, debe ser imitado en España adoptando al efecto las prácticas de cultivo 
conducentes para aumentar las cosechas y abaratar los productos (I), y dar mayor extensión a la siembra de cereales; pues de los 50 millones de hectáreas que según el Instituto Geográfico y Estadistico constituyen la superficie total de España, no resultan de los amillaramientos más que 13 millones de hectáreas destinadas al cultivo de cereales, que dan una producción media anual de 36 á 40 miliones de hectólitos de trigo (2).

$\mathrm{El}$ aumento en la producción es un factor importante para que los productos puedan

(1) Que consisten en mejorar la cantidad de las tierras, por la aplicación de los riegos y abonos, buenas labores, maquinaria agrícola moderna, empleo de buenas semillas, acomodadas á las condiciones del suelo y clima de cada región, superior elaboración de las harinas, venta del pan en relación al precio del trigo, facilitar los arrastres, rebajando en cuanto sea posible las tarifas de transporte, y construir vías férreas secundarias, carreteras y caminos vecinales, protección arancelaria y otros medios anteriormente indicados.

(2) Sevilla y Valladolid son las dos primeras provincias productoras en trigos, pues en un año ordina- : rio producen entre ambas 4.224 .000 hectólitros.

La producción total de cebada es aproximadamen. te de 18.000 .000 de hectólitros. Badajoz y Toledo que son las dos provincias más productoras, suman entre una y otra en cada año ordinario 3.259 .000 hectólitros. 
resultar baratos, y para que el consumo del pan de trigo sea mayor en todas las regiozes de España; á cuyo fin deben encaminar sus propósitos los agricultores, siquiera hasta conseguir que la cosecha ordinaria de trigo no baje de 42 millones de hestólitros que se conceptúan necesarios todos los años para el consumo de dicho articulo, la siembra y exportar á nuestras posesiones ultramarinas(I); siendo el mejor medio de evitar los importantes arribos que llegan à nuestras costas.

aEn 1893 hemos adquirido trigo por 83 millones de pesetas, sin exportar apenas harina. Pues bien claro se ve, que si nuestra pobre España se ahoga en vino, en cambio sufre hambre de pan. Ese es el desequilibrio de la producción agraria; ¿por qué no habia de dar nuestra tierra la mayor parte de las substancias alimenticias que nos cuestan 180 millones anuales? Con seguridad que ciento de ellos (en cereales y legumbres gastamos 93) podrian quedar en el pais y tendriamos el triple beneficio de emplear las tierras en cultivos remuneratorios, de producir para el consumo de nuestro mercado interior, y no enriquecer con nuestro oro (pues en oro,

(1) Ya hemos dicho en la Parte primera Cap. IV, que Francia y otras naciones han conseguido aumentar considerablemente sus productos, por los conocimientos agricolas y las buenas prácticas de cultivo. 
aunque no se vea, pagamos) el mercado extranjero (I)".

$Y$ en efecto, los muchos millones de pesetas que pagamos al extranjero todos los años por ser deficientes las cosechas de cereales y legumbres, podian quedar en España aumentando la producción de tan indispensables artículos de consumo. Verdad es que las muchas y considerables importaciones hacen aumentar la renta de Aduanas; pero es porque compramos más que vendemos, y porque en los centros productores é industriales del interior escasea la demanda, lo cual origina la baja de los cereales, y la paralización de las muchas é importantes fábricas en aquel establecidas; siendo un signo bien evidente de nuestra pobreza, y esta lo será cada vez mayor de continuar en tan anómala situación, porque el dinero que sale de la pátria no vuelve à ella.

(1) Navarro Reverter, en su detenido estudio sobre La verdad de un presupueslo; y. ahora que es Jefe del más importante Departamento ministerial, esperamos que llevará á la práctica las medidas proteccionistas que el país reclama; y que desarrollará su programa económico en beneficio de las clases productoras, ya que la ocasión es la más propicia para ello. 
La baratura de los cereales.

La depreciaciún que en la actualidad sufren los cereales, ha producido general clamoreo entre los labradores, que no ven recompensados sus afanes y trabajos, $y$ hace preocupar honda y seriamente á cuantos se interesan por la regeneración de la clase agricola, base y apoyo de todas las demás de la sociedad.

Este mal no es exclusivo en España, pues lo propio acontece en Inglaterra, cuyos precios lo mismo en los trigos que en las harinas han bajado un 40 por 100 en el periodo de diez años. En Bélgica desde I877 á 1895, el trigo que se vendia á 30 francos el hectólitro, bajó á II; el centeno, de 20 á Io; la cebada y avena de 21 á 15 y á 16 respectivamente. En Francia que ya se habia iniciado la baja en 1893, se acentuó más en el siguiente año, pues de 83 millones de hectólitros cosechados en aquel año, ascendieron á I 32 en I 894 (I), sin que sean necesarios para su consumo más de 120 millones; de manera que si continúa en ascenso la producción de cereales en dicho pais, se convertirá de importador en exportador, y la baja de precios que existe

(1) La cosecha de 1895 ha disminuido 13 millones de hectólitros. 
en otras naciones respecto a los cereales, no puede menos de repercutir en la nuestra.

Además, si la abundancia ó escasez de un artículo, así como también el pedido y la oferta, forman siempre la base para que los. precios sean bajos ó altos, y habiéndose importado en España más trigo del necesario para su consumo, forzoso será reconocer, como consecuencia lógica y natural, que el exceso de la importación ha tenido que ocasionar la baja de los cereales y sus harinas.

Los precios que rigen en España para los. cereales, particularmente en las dos Castillas y Aragón, no son en verdad remuneradores; peroes preciso noolvidar que los trigos extranjeros se venden hoy (I) en las costas al insignificante precio de ig reales fanega; y ya que casi no existe el factor que antes más cohibía. el tráfico de los productos agrícolas, que era. la distancia (2), lo verdaderamente práctico y conveniente por ahora es aumentar la producción, para establecer los precios en el interior de la Peninsula en relación con los

(1) Enero de 1896.

(2) Las condiciones por tierra encarecen demasiado los frutos, y todavía en igualdad de precios llegarán más baratos á Santander los granos extranjeros conducidos por agua que los de Castilla por tierra. Aunque la fanega de trigo se vendiese en Palencia a 6 reales, como sucedió por ejemplo en 1757, su precio en Santander sería de 22 reales, sin embargo de ser el punto 
que rijan en los mercados exteriores, cuyas cotizaciones no deben olvidarse, á fin de que los fabricantes del litoral acudan á comprar al interior (como suelen hacerlo cuando los precios son tan ventajosos como los del extranjero) y harian un gran bien á los labradores españoles, cumpliendo además con un deber de patriotismo, si para el desarrollo de sus industrias prefieren los trigos nacionales á los extranjeros.

Legumbres y otros diversos productos.

A fin de establecer el equilibrio en la producción para que la abundancia no se deje sentir en unos artículos y escasear en otros, y evitar al propio tiempo cuantiosas pérdidas, como sucede cuando la cosecha de trigo resulta escasa, bien por las tempestades, las sequias prolongadas, ó por las plagas que devastan una gran parte de las cosechas, los labradores para aliviar en parte la penuria en que se encuentran por la circunstancia insinuada, y también y muy principalmente

más inmediato. ¿Igual sería allí el de los trigos de Campos tanto más distantes? He aquí lo que basta para justiticar la empresa del canal de Castilla, cuando no lo estuviese por el objeto del riego que tanto la recomienda. (Jovellanos, en su célebre informe sobre el establecimiento de Ley agraria, núm. 397). 
por la depreciación lamentable al más interesante producto de la tierra, deberán contar en todo caso con los rendimientos de otros productos que rara vez se pierden en los mismos años que los cereales, ó tienen igual depreciación que éstos.

Las legumbres constituyen un auxiliar poderoso, un producto importante para el consumo, y una fuente de recursos de bastante cuantia, y por tanto deberá utilizarse el cultivo de tan valiosa producción en combinación con la de cereales; como igualmente atender al fomento de la ganadería y el del arbolado, la fabricación del aceite, la explotación de minas y canteras; farorecer el desarrollo de la sericultura, el cultivo de las raices alimenticias ó tubérculos (patata, batata, remolacha, etc.), el de las plantas textiles (lino, cáñamo, algodonero, esparto etc.) y las tintóreas (la rubia, el azafrán, la gualda, el añil, el alazor, etc.), sin descuidar el dela vid, aunque de escasos ó nulos rendimientos; el de los prados, ya naturales ó artificiales, anuales ó perennes, según para cada caso mejor conviene, á fin de asegurar el sustento de los ganados (por medio de la alfalfa, el trebol, la lupulina, etc.); las frutas verdes y secas; toda clase de hortalizas; la cria de aves de corral; y cuantos medios ó elementos constituyan aumento de riqueza y puedan compensar las pérdidas eventuales de unos 
productos con los rendimientos de otros, evitar en los mismos sensibles paralizaciones $\mathrm{y}$ depreciaciones; normalizar y equilibrar la producción nacional; puesto que no consiste en producir mucho, sino lo que más convenga.

Modificar las tarifas para el transporte de productos agrícolas bajo la base de percepción por unidad de tonelada y kilómetro de recorrido.

Una de las causas, aunque secundaria, que más se opone al desarrollo de la riqueza territorial é industrial, es la elevación de precios para los transportes; pues para atravesar la nación con algunos productos, hay que pagar más de lo que ellos valen.

A facilitar los transportes, cambiar y vender los productos, desarrollar la riqueza agricola y pecuaria, la industria y el comercio deben contribuir las Compañias ferroviarias, si han de responder al importante objeto que de ellas se esperaba cuando se hicieron las concesiones para la construcción de los caminos de hierro, y si España ha de vivir en el concierto universal.

Tampoco puede exigirse mucho de las referidas Empresas, pues la crítica situación porque atraviesan no las permitirá otra cosa 
que auxiliar en una pequeña parte los intereses de la agricultura y ganaderia, y aun esto á trueque de alguna ó algunas concesiones que compensen las pérdidas ó perjuicios que se les irroguen.

Aun cuando sea pequeño el beneficio que con la modificación de las Tarifas de ferrocarriles se obtenga, y no se consiga por él solamente hacer la competencia á los trigos extranjeros, no habrá de prescindirse del mismo, pues es de necesidad absoluta aunar todos los factores para poder llegar al fin apetecido, que no es, ni puede ser otro en la ocasión presente, que el de conseguir un precio nivelador para que los trigos y harinas nacionales, puedan competir con los extranjeros.

Por el transporte de los trigos desde $\mathrm{Va}$ lladolid á Santander se satisface actualmente conforme á las Tarifas especiales 27 pesetas por cada tonelada de 100 kilógramos equivalentes á 23 fanagas) y 4 I, 58 pesetas por la tarifa general; siendo mucho más reducidos los fletes marítimos desde los puertos de los Estados Unidos á los de Europa (1) y que

(1) Las Compañías Trasatlánticas tienen fijado el flete de cinco centavos por bushel de trigo de Nueva York á Europa, y las de Cunard y Leyland conducen trigo de Bostón á Liverpool por la insignificante suma de cuatro centavos bushel, ó sean treinta y siete cén. timos de peseta la fanega. 
además del costo, seguro, diferencia del cambio y los derechos de Aduanas, corretaje etcétera, resultan los trigos extranjeros en nuestros puertos á un precio más bajo que los del pais en los mercados del interior de nuestra Peninsula (I).

En vez de elevar las tarifas de los ferrocarriles (como pudieran verificarlo las Empresas en uso de su legitimo derecho hasta el limite que autorizan las respectivas concesio. nes) es necesario modificarlas en beneficio de los productos agrícolas y pecuarios; siquiera la modificación se limite á las mercancias que se remitan del interior à las costas.

Compleja es en verdad esta cuestión, y al acometerla es muy fácil exponerse á lesionar intereses creados a la sombra de las leyes, pero conceptuamos que la modificación deberá hacerse en el sentido de disminuir los precios del transporte y unificar las tarifas bajo la base de percepción por unidad de tonelada y kilómetro de recorrido para que, además de los comerciantes en gran escala, pueda disfrutar el público en general de las ventajas que resulten, evitando a la vez competencias

(1) Así que los labradores y los fabricantes de harinas del interior, más que la baja de tributos, desean facilidades y economías para los transportes de sus productos al litoral para poder competir con los que llegan al mismo del extranjero. 
entre las mismas Compañias, y entorpecimientos y dificultades a los expedidores y receptores, y favorecer á unas comarcas en perjuicio de otras, pues la limitación del mínimun del recorrido para obtener el beneficio de la rebaja sustrae importante parte del tráfico; debiéndose por último formar las nuevas tarifas con la mayor claridad y sencillez con el objeto de evitar errores y confusiones por parte del público.

\section{Compensación á las Compañías}

\section{ferroviarias.}

Que las Compañias de ferrocarriles sufren desde hace tiempo una honda crisis, producida por la disminución de los transportes y por la elevación de los cambios que las afectan de una manera directa, en razón á que satisfacen cuantiosas obligaciones en el extranjero, no hace falta demostrarlo porque todo el mundo lo reconoce.

Nadie ignora que las empresas concesionarias solo tienen el usufructo de los ferrocarriles durante el plazo de la concesión, por ser aquellas propiedad del Estado, y que el crédito de sus valores padece de una manera considerable; como lo demuestra la baja que vienen experimentando sus acciones, particularmente las del Norte. 
La disminución en los ingresos por razón de tráfico es mayor cada año, pues solamente en el de i $\$ 95$ fué en la linea del Norte de más de 3 millones de pesetas, y desde i89 I la Compañia no ha repartido à sus accionistas cantidad alguna. Lo propio sucede en la linea de Madrid á Zaragoza y á Alicante, pues desde 1892 que los accionistas percibieron menos de 5 francos por acción, no han vuelto á cobrar dividendo alguno; y sabido es que hoy uno de los capitales menos lucrativos, es el invertido en la lineas férreas.

Las Compañlas concesionarias se hallan autorizadas para cobrar los derechos dé peaje y transporte que se expresan en lastarifas de cada concesión(I), conforme à lo preceptuado en los arts. 31 y 32 de la ley de 3 de Junio de 1855 , cuyas disposiciones han sido reproducidas por los arts. 45 y 46 de la vigente ley general de ferrocarriles de 23 de Noviembre de 1877 , y no obstante haciendo uso diferentes reces de la facultad que les confiere la misma ley, y cediendo en otras á las excitaciones del Gobierno, han bajado los precios en sus tarifas generales y los han reducido

(1) Art. 40ั. Todo ferro-carril tendrá dos aprovechamientos distintos; el de peaje y el de transporte.

Art. 46. Los precios de uno y otro serán los que señalen las tarifas que rijan en cada línea. 
bastante más en las tarifas especiales, en algunas de las cuales exceden las rebajas de un 60 por 100 de los precios legales, en beneficio de la agricultura, la industria y el comercio, y á pesar de la situación tan crítica porque atraviesan, es de esperar que no se opongan á las nuevas concesiones necesarias para el fomento de la riqueza agricola y pecuaria.

Pero al propio tiempo es necesario que, en justa reciprocidad, se concedan algunas ventajas para compensar las pérdidas que habrán de experimentar por las nuevas rebajas ó concesiones insinuadas; pues por más que muchos opinan que abaratando los transportes, el tráfico aumentará considerablemente, aun cuando sea probable que así suceda, no sabemos si tal aumento produciría ganancias ó pérdidas; y si bien la ley últimamente citada otorga al Gobierno la facultad de revisar las tarifas máximas legales y rebajar sus precios, no es para perjudicar los intereses de las empresas, sinó para garantir los productos totales del último año, si aquellas no conviniesen en la reducción, y además el aumento que por término medio hayan tenido en el último quinquenio. (I).

(1) Art. 49. Pasados los cinco primeros años de hallarse en explotación el ferro-carril, y después de cinco en cinco años, se procederá á la revisión de tarifas. 
Dificil es, sin embargo, precisar la manera de hacer la compensación, y más dificil aún determinar la cuantía de la misma; pero conceptuamos que en todo caso habrá de ser equitativa y proporcionada á la que por término medio representen las rebajas que se concedan.

A tal fin será conveniente que el Gobierno procure que se active la discusión del proyecto presentado al Congreso en Junio de 1894 , ya que por la falta de tiempo no lo fuera el de 13 del propio mes de ${ }_{1} 892$, sobre auxilio á las Compañias de ferrocarriles, admitiendo las reformas ó modificaciones que fueren aceptables, ya consistan en recargar los billetes de viajeros, particularmente en los trenes expresos, por la ventaja de la comodidad y rapidez del viaje; ora las tarifas para las mercancias en gran velocidad, ya autorizar á las Compañias para suspender la amortización de sus obligaciones por un término de varios años; ya en la prórroga de sus concesiones por un plazo determinado, ó en cualquier

Si el Gobierno creyese que sin perjuicio de los intereses de la empresa, pueden bajarse los precios de ellas, y ésta no conviniese en la reducción, podrá sin embargo, llevarse á efecto por una ley, garantizando á la empresa los productos totales del último año y además el aumento progresivo que hayan tenido por término medio en el illtimo quinquenio. 
otra que sirva para compensar y harmonizar los intereses de todos.

Prohibición de importar los productos extranjeros que no sean necesarios.

La depreciación lamentable y constante de los cereales y legumbres, (pero en particular del trigo), es una de las causas principales del angustioso estado en que se encuentran la mayor parte de los labradores.

Sabido es, que en la actualidad se cotiza el trigo en los mercados, á igual ó más reducido precio que el que cuesta el producirlo, sin que haya sido suficiente á elevarle á un precio modicamente remunerador, el recargo arancelario establecido por la ley de 9 de Febrero de 1895 , á pesar de que la cosecha del mismo año ha sido escasa en nuestra nación, así como también en Rusia, Francia, y otros paises, cuya circunstancia ha hecho descender la producción de trigo en el mundo á muy cerca de 100 millones de hectólitros de la cosecha de 1894 .

Muchos atribuyen al contrabando la baja de los cereales, asegurando que aquel suple con exceso lo que las aduanas recaudan de menos.

Claro es, que nadie con razón podrá negar que no exista contrabando en mayor ó 
menor escala, porque es algo dificil vigilar bien las costas y fronteras; pero es preciso reconocer que el impuesto de Aduanas, es uno de los que mejor administrados se hallan en España, pues las muchas aprehensiones que realizan sus empleados, las repetidas visitas de inspección, giradas con resultados satisfactorios, y los considerables aumentos obtenidos, sor pruebas que dicen mucho en pró de su administración.

Además, sin haber aumentado el consumo ni la población, y sin que las cosechas de 1893 y 1894 hayan sido tan deficientes han entrado en España pagando derechos en los dos expresados años 840 millones de kilógramos, ó sean cerca de 20 millones de fanegas de trigo extranjero, pues ¿qué falta hace contrabando para que los trigos bajen?

Como los trigos nacionales no pueden competir en el precio con los extranjeros, ni compensar los crecidos gastos de producción, es preciso adoptar algún medio práctico, sin perjuicio de losya anteriormente expresados.

El arriendo de los derechos de Aduanas, además de no remediar el mal que lamentamos, pudiera dar lugar á confliços y abusos, aún con ciertas garantias y condiciones.

El pago en oro de los derechos arancelarios nada resolveria y tal vez ocasionase mayor depreciación en la plata y en los billetes de Banco. 
El establecer derechos muy elevados, no impediria considerables importaciones, y pudiera contribuirá que se cometieran muchos abusos é inmoralidades.

Prohibir de una manera absoluta y definitiva las importaciones de cereales, legumbres y sus harinas, seria el mejor medio de evitar el contrabando y competencias ruinosas; pero podría encarecer demasiado un artículo tan indispensable para la vida. Además en la actualidad no producimos lo suficiente para el consumo, la siembra y exportación colonial, como así lo evidencian las partidas tan enormes de referidos productos que procedentes del extranjero llegan á nuestros puertos; y por otra parte el presupuesto deingresos del Estado habria de resentirse al prescindir por completo de los derechos arancelarios.

El no permitir la entrada à más trigo que lo preciso entre lo cosechado y lo necesario para el consumo y la siembra, es en nuestro concepto, la solución más acertada y de la que desde luego pueden obtenerse más provechosos y positivos resultados, siguiendo en esta parte el sábio y previsor criterio adoptado en Portugal que à pesar de haber elevado diferentes veces los derechos sobre los cereales, regula en la actualidad por decreto las cantidades de trígo que periódicamente pueden ser importadas, con el laudable fin 
de que no desciendan sus precios en perjuicio de los agricultores de aquella nación (I).

Ya hemos afirmado que el exceso de importación es el principal factor que ha ocasionado en nuestro pais la considerable baja en los precios de los cereales, sus harinas $y$ legumbres, y el medio de que nos ocupamos, es el que mejor puede limitar las invasiones extranjeras, y elevar á su nivel ordinario $y$ remunerador el precio de los productos mencionados (2).

El único inconveniente que por ahora ofrece es el de carecer en España de una estadistica verdad acerca de lo que se siembra, cosecha y consume en cada año, pero tal inconveniente puede subsanarse con el nombramiento de una Comisión que, prévio un detenido estudio y con datos fidedignos y completos, forme la estadistica insinuada, como base de preciso conocimiento, á fin de que el Gobierno pueda limitar las importaciones á lo que demuestre la necesidad, y hasta tanto se lleva à efecto tan importante servicio,

(1) Por Real decreto de 14 de Noviembre de 1895 , se fijó en 140 millones de kilógramos de trigo de procedencia extranjera, cuya importación queda autorizada en Portugal hasta el 31 de Julio de 1896; de los uuales 135 serán destinados á la panificación y los 5 restantes para pastas.

(2) Sin perjuicio de lo que exija la necesidad en casos ó circunstancias excepcionales. 
debe acordarse cuanto antes la prohibición absoluta de importar en España é Islas Baleares, cereales y harinas, mientras el valor del trigo no exceda de 12 pesetas la fanega en los mercados interiores (cuyo precio es el que pudiera servir de norma para sostener ó alzar la prohibición indicada), y cuando excediere, el Gobierno podria permitir la entrada de lo que fuere necesario hasta que el referido artículo quedase de nuevo reducido al susodicho precio de 12 pesetas; debiendo guardar la propia relación los demás cereales, sus harinas y legumbres, y adoptar al propio tiempo las precauciones conducentes para que los beneficios que resulten de $\tan$ indispensable y ansiada medida, no redunden exclusivamente en beneficio de los industriales y acaparadores de repetidos productos.

Por tanto, urge decretar la prohibición. absoluta de importar cereales, legumbres y harinas, hasta tanto que las circunstancias aconsejen y requieran dejarla temporalmente sin efecto á fin de permitir la entrada de las cantidades que sean necesarias para completar el déficit resultante entre la producción, el consumo y la siembra; como medio práctico y eficaz de conseguir la venta de los mismos productos á precios remuneradores, sin afectar en ello á la marcha normal del Estado. 
Sin perjuicio de la referida prohibición, y para fomentar las exportaciones, conceptuamos que también serà conveniente conceder primas á los que exporten trigos y harinas nacionales (ya sean ó nó importadores), bien consistan en cuotas equivalentes á los derechos de importación, ó en una cantidad razonable y prudente, en relación á la clase y cantidad exportada, de manera que sin perjudicar considerablemente los intereses del Tesoro, favorezca los de la producción nacional; y si por tal circunstancia aumentasen las exportaciones, una vez que éstas se realicen, permitir asimismo importar iguales ó aproximadas cantidades que las que se hayan exportado, á fin de que no haya abundancia ni carestia de tan valiosos é indispensables productos.

Elevar prudencialmente el arancel para los cereales y harinas que se importen en España y sus posesiones de Ultramar.

Los derechos arancelarios que han venido rigiendo para la importación en España de trigos y demás cereâles desde que empezó á regir la base $50^{\circ}$ del Apéndice letra $C$ à la ley del Presupuesto de ingresos de $10^{\circ}$ de Julio de 1869 , han sido considerados como muy reducidos, y à cuya circustancia se han atribuido los importantes arribos á nuestras 
costas y la depreciación del trigo y sus harinas, en perjuicio evidente de la producción nacional.

$\mathrm{El}$ interesante voto particular del Sr. Vizconde de Campo Grande, al dictamen de la Comisión acerca de las causas de la crisis de los cereales y legumbres, y medidas que pudieran remediarla, después de un detenido estudio, opinando con muy fundada razón, con la casi unanimidad de los informantes, que los derechos del Arancel de Aduanas, no eran compensadores ni niveladores de las grandes diferencias del coste de producción entre nuestros cereales y los que se producen en la América de la India, y en la Australia en los últimos años, como no lo eran desde I869, para luchar con los que llegaban de Rusia, Turquia y Argelia, y al ver preferida tan importante medida, proponia como la primera, más esencial y urgente medida, para remediar la crisis, el recargo de un 30 por roo sobre los derechos entónces establecidos, á fin de llegar á nivelar el precio con los productos similares extranjeros, ó aproximar siquiera la nivelación, y dejar márgen al beneficio que pudiera alcanzarse por los medios indirectos y al estimulo de los productores.

La Comisión nombrada por Decreto de ro de Octubre de 1889 , para la Reforma arancelaria y Tratados de Comercio, de acuerdo 
con la mayoria de los informantes propuso. entre otros importantes particulares, se derogase la Base $50^{2}$ y toda la legislación arancelaria entónces vigente.

Remediar una necesidad sentida y reclamada por la opinión pública tuvo por objeto el Real decreto de 24 de Diciembre de 1890 , pues el Gobierno, haciendo uso de la autorización concedida por el art. 38 de la ley de Presupuestos de 29 de Junio del mismo año, elevó 2'30 pesetas en cada 100 kilógramos de trigo, y otro recargo análogo en las harinas, cuyos aumentos ó recargos sirvieron si no para elevar entónces el precio de nuestros trigos al nivel del de los extranjeros, á lo menos para aproximarle en todo lo que representaba el valor de tales recargos favoreciendo al propio tiempo los intereses del Tesoro.

Que fué acertada y previsora tal medida lo prueba el hecho de haber aumentado las importaciones, pues ascendiendo las de 1893 y 1894 á 415 y 425 millones de kilógramos respectivamente, sólo por el aumento ó recargo insinuado, han satisfecho $19^{\prime} 3$ millones de pesetas.

La experiencia demostró claramente que el precitado recargo fué insuficiente, pues los trigos extranjeros inundaban nuestros mercados del litoral, ocasionando perjuicios enormes á los productos nacionales, lo 
cual produjo ayes y lamentos en los labradores, que hallaron eco fiel en la prensa periódica, particularmente en las provincias castellanas, y á sus expontáneas y plausibles excitaciones, y á la de algunos Diputados amantes del bienestar de los pueblos, verdaderos defensores de los intereses agrícolas, se debió la imponente y grandiosa asamblea celebrada en Palencia (1), y la reunión de diferentes Diputaciones provinciales (2), acordando dirigirse á los Poderes públicos en solicitud de un recargo arancelario para los trigos y harinas que se importasen en España.

El Sr. D. Narciso Rodriguez Lagunilla, Diputado á Córtes por la circunscripción de Palencia, presentó en el Congreso el ro de Diciembre de 1894 , una proposición pidiendo un recargo arancelario de 4 pesetas (3) á los 100 kilógramos sobre los trigos de procedencia extranjera que se presentasen para su

(1) El 14 de Octubre de 1894.

(2) Las de Ávila, Búrgos, Guadalajara, León, Palencia, Salamanca, Valladolid, Zamora y otras, por iniciativa de la de Palencia que tanto se distinguió por su campaña brillante en favor de los agricultores.

(3) Si bien al formular el voto particular y como medio de transación redujo á $3{ }^{\prime} 50$, que tampoco faé aceptado. 
adeudo é importación en las aduanas de la Peninsula é Islas Baleares, como medio de contrarrestar la avalancha formidable de cereales extranjeros que amenazaba de muerte á nuestra producción nacional y de elevar algo el reducido precio de los trigos españoles; y no obstante haber sido tan módica, concreta y limitada su loable y legitima proposición en la que entónces se hallaban contenidas las aspiraciones del pais productor, no logró ver satisfechos sus justos deseos por la oposición que halló en los elementos librecambistas y la dificultad de armonizar las dos tendencias tan opuestas, que en materias económicas se hallaban divididos los Diputados que entónces constitulan la mayoria del Congreso (I), pues mientras unos pretendian negarlo todo, otros deseaban aceptar integro el recargo propuesto, y en las minorias habia quienes anhelaban un recargo más elevado, una protección mayor y un remedio más enérgico, conforme à lo que demandaban las circunstancias $y$ las necesidades de la agricultura; por lo cual en la sesión del 4 de Febrero de 1895 , al discutir el voto particular del Sr. Lagunilla, el señor

(1) No habiendo admitido tampoco otra proposición de los Sres. Aparicio, Corzana, Muro, y otros, por la que sus autores pedian solamente tres pesetas de aumenio en el Arancel para los trígos exóticos. 
Gamazo expuso: "Mi opinión es favorable al dictamen, y aunque hubiera deseado otra cosa, no pudiendo obtenerla, acepto las 2'50 pesetas».

El Sr. Muro, en su nombre y en el de la minoria que representaba, dijo: "Nosotros entendemos que la primitiva proposición del Sr. Rodriguez Lagunilla, podia llevar algún alivio à la maltratada agricultura; nosotros entendemos que el voto particular del mismo señor, objeto del debate actual, es notoriamente insuficiente para que ese alivio se produzca; nosotros entendemos que el dictámen de la mayoria de la Comisión, que tanto se aparta de la primitiva proposición de ley, y mucho también del voto particular, es todavia más insuficiente; y por tales motivos, y por la necesidad en que nos encontramos de optar por lo menos malo, nosotros votaremos el voto particular del Sr. Rodriguez Lagunilla).

Y el Sr. Cos-Gayón, en nombre de la minoria conservadora: "Nosotros hemos dicho sin ningún reparo, sin ningún inconveniente, que en el estado actual de la agricultura nos parece insuficiente la proposición del Sr. Rodriguez Lagunilla; pero que sin embargo la rotaremos á falta de otra cosa mejor".

Después de cerca de dos meses de ince. santes trabajos, peticiones, fórmulas, conferencias, transaciones y regateos, sólo pudo 
conseguirse un recargo de 2 '50 pesetas en los derechos arancelarios (I), y esto nada más que con el carácter de provisional, ó sea hasta el 3 I de Diciembre de 1895 (2), ó lo que es igual un ligero paliativo, un alivio fugaz, un medio sin eficácia; y el voto particular del Sr. Lagunilla fué desechado por 172 votos contra $78(3)$.

(1) A los 100 kilogramos de trigo. El recargo para las harinas se fijó en $4^{\prime} 12$ pesetas y en 2 el de los salvados; lo cual no satisfizo las aspiraciones-de las Diputaciones provinciales reuridas en Asamblea, ni los deseos de los labradores, los cuales venden en la actualidad el trigo á un precio más inferior de! coste de producción.

(2) Si bien por Real decreto de 13 de Diciembre de 1895 se ha prorrogado la exacción del expresado recargo hasta un mes después de reunidas las Cortes.

(3) Los Diputados que apoyaron el voto particular fueron los siguientes:

Sres. Conde de la Corzana, Conde de Vilana, Avelillo, Gurrea, Bushell, Barrio y Mier, Sánchis, Dato, Rodriguez (D. Calixto), Pombo, Torres (D. Pedro Antonio), Dominguez Pascual, Cabezas, Soriano, Lema (Marqués de), Figueroa (Ilarqués de), Elduayen, Vía, Manuel (Conde de), García Alix, Córdova, Monistrol (Jlarqués de), Junoy, Ordoñez, Baró, Llorens, Casasola (Conde de), Zubizarreta, Sanz, Castro, Sánchez de Toca, Henestrosa, Osma, Castellano, Casa Torre (Marqués de), Viesca, Rodriguez San Pedro, Muro, Lostau, Viñaza (Conde de la), Monedero, Troncoso (Conde de), Serrano, Campión, Navarro Reverter, 
Es necesario que se persuadan nuestros politicos y gobernantes que los intereses agricolas demandan con irresistible imperio una protección mayor, más decidida y de más reconocida eficacia; no una reforma deleznable y transitoria, sino un remedio eficáz y perenne; que á la planta débil sustituya otra robusta, y á la flor de un sólo dia, la siempreviva de eterno é imperecedero recuerdo.

Por consiguiente, además de la prohibición ya indicada, y por si llegamos á precisar poco ó mucho de las producciones extranjeras, un nuevo aumento (1) prudencial y permanente en el Arancel, sobre el establecido por la ley de 9 de Febrero de 1895 , es el que

Cos-Gayón, Romero Robledo, Gil Becerril, Seo de Urgel (Duque de la), Silvela (D. Eugenio), Cárdenas, Ruiz (D. Gustavo), Villaverde, Rodrígnez Lagunilla, González Medina, Serrano Alcazar, Isasa, Esteban, Alvear, Camacho, Cánovas, Linares Rivas, Martín Sinchez, Aguilera (D. Luis Felipe), Vila Vendrell, Bores y Romero, Silvela (D. Francisco), Comyn, Aparicio (D. Francisco), Pablos, Castell, Vérgez, Camisón, Suarez Valdès, Vadillo (Iarqués del), Pidal, Carvajal y Trelles, Revillagigedo (Conde de), Bnstillo.

(1) En la Parte primera cap. V, queda consignado que Alemania, Italia, Francia y otras naciones, se han visto obligadas diferentes veces á elevar los derechos de importación á los cereales y sus harinas para nivelar los precios. 
conceptuamos indispensable para que el precio del trigo compense los gastos de cultivo; pues no obstante haber sido tan reducida la última cosecha de cereales, los precios de éstos ya que no elevados, debieran ser siquiera remuneradores y continúan sin embargo siendo ruinosos, porque el trigo se vende en Castilla y en casi todos los demás centros productores al insignificante precio de 35 . reales la fanega de 94 libras (I) que es proximamente lo que cuesta el producirlo (2).

El recargo arancelario de 2 '50 pesetas á los Ioo kilógramos de trigos exúticos equivale al de I'o8 pesetas en cada fanega, cantidad que, aunque insignificante, y que supone la de cualquier oscilación en alza ó baja en el precio del mismo cereal, no conviene despreciarla, porque todo lo que la misma representa puede ser mayor valor para los trigos que se produzcan en España, pues mientras

(1) A más reducido precio se ha vendido la mayor parte de lo cosechado en 1894 y 95 .

(2) En el corriente ejercicio se ha venido cotizando \& 8,50 pesetas, siendo 7,64 los gastos de producción de una fanega, y l,30 el total de impuestos con que está gravada, en junto 8,94, resulta que no solo no reporta beneficio el cultivo del trigo en España. sino que ocasiona una pérdida de 44 céntimos en fanega. (J. Martínez en un luminoso artículo sobre Producción nacional de trigo). 
en nuestra nación particularmente en Castilla los precios de los trigos aumentaron una peseta en fanega á raiz de establecer el mencionado recargo, descendieron los precios de los cereales en Chicago, Lóndres, y otros mercados.

Por lo tanto, bien claramente se ve que el aumento obtenido en España en el precio del trigo y sus harinas, fué debido á la expresada ley de 9 de Febrero de 1895 (I).

Pero no basta con que el ya repetido recargo sea transitorio, ni tampoco con que se le declare permanente, sino que es necesario robustecerle más y más á fin de que el precio del trigo no baje en los mercados de ro pesetas como minimun, ya que hoy la protección decidida aplicada con oportunidad (2) es el mejor remedio para aliviar la triste situación de nuestros abatidos agricultores.

La baja de los trigos obedece principalmente al exceso de importación, y cuyo

(1) Que sabido es molivó la proposición del Señor Lagunilla.

(2) Y decimos que con oportunidad, porque como la campaña parlamentaria para el recargo acordado sobre los trigos y harinas fué tan laboriosa, no obstante la pequeña concesión obtenida, permitió á los negociantes las importaciones de enormes partidas de trigo; por cuya circunstancia pudieron eludir el cumplimiento de la ley, en perjuicio evidente de la producción nacional. 
exceso no aparece justificado por el aumento de consumo ni de población, así como tampoco por ser muy deficientes las cosechas, pues la de 1891 no fué abundante y sólo de que Rusia prohibió exportar sus cereales, las importaciones fueron más reducidas, los trigos alcanzaron mejor precio, y sin embargo se atendió á las necesidades del consumo.

Asi pues, sin perjuicio de la prohibición temporal mencionada, y para cuando se permita la entrada á los productos extranjeros que sean necesarios, conviene establecer un nuevo recargo racional y prudente, á fin de limitar las invasiones; reducir las competencias, y que los labradores vean suficientemente remunerados sus afanes y trabajos. Si debido á los medios propuestos es menor la importación y disminuye, por tanto, la renta de Aduanas, será altamente satisfactorio para los agricultores, porque cohibida la competencia, podrán con mayor facilidad dar salida á sus productos á precios algo más elevados y resistir mejor el pago de los impuestos; y ya que el Estado vive principalmente de la agricultura, no habrá de consentir que los labradores sucumban ante la concurrencia irresistible de la producción extranjera. 
Vigilancia especial en las costas y fronteras.

Por lo mismo que los derechos de importación para los trigos y harinas son algo más elevados que lo eran antes; y por si se elevaran más aún en lo sucesivo, es de inferir que la defraudación tenga mayor áliciente, $y$ por lo tanto se hace necesario ejercer una vigilancia especial y constante para evitar el contrabando con las mercancías que llegan $\dot{a}$ las costas y fronteras españolas; pues de no. hacerlo asi vendrán á resultar ilusorios los recargos establecidos y los demás que en lo sucesivo lleguen á establecerse.

Dicese públicamente que el contrabando, se ejerce en grande escala con gran detrimento de los intereses morales y materiales de la nación; que muchos buques con cargamento de trigo pasan el estrecho de los Dardanelos y suelen escogitar localidades determinadas, siendo de notar que muchos dirigen sus miradas á Gibraltar, cuyo sitio sirve de centro á sus operaciones, porque aquella población y las inmediatas viven del contrabando, y que á esto obedece principalmente la baja del precio de referido producto, pues siendo los derechos más elevados, que tiene que ser mayor el contrabando.

Aun cuando tráfico tan ilegal, como lo es el contrabando, no sehaga en las proporciones. 
escandalosas y alarmantes que muchos aseguran, sin embargo, no debe ser obstáculo para que el Gobierno procure que se ejerza la más asidua vigilancia, recompense méritos y servicios, y que se apliquen con todo rigor las disposiciones penales de las ordenanzas generales del ramo (I) a fin de que no se cometan defraudaciones, y los trigos exóticos hagan una competencia ruinosa y desleal á los del pais; porque de nada sirve que se eleven los derechos arancelarios si se deja abierta la válvula de la inmoralidad, mil veces más terrible y funesta que las heladas, el granizo, las plagas y las inundaciones, pues á modo de cáncer destruye lentamente el organismo invadido; gotera que horada y arruina el edificio nacional; parásito que absorve la savia del pais productor.

Toda medida que tiende á evitar ó disminuir la defraudación y el contrabando será altamente beneficiosa para nuestros sufridos agricultores que hoy no pueden sostener la competencia que trae à sus cereales las producciones extranjeras. Además muchos sospechan que en importantes poblaciones maritimas el consumo de cereales es mayor que lo que aparece en los registros de Aduanas, $\mathbf{y}$

(1) De 15 de Octubre de 1894. 
que los trigos exóticos se venden en diferentes ocasiones en los mercados del litoral á más reducido precio que en los puertos de embarque del Mar Negro, del Danubio y que en algunos de,América, descontados los gastos de carga, descarga, fletes, diferencia del cambio, seguros y los derechos de Aduanas; y de ser cierto, no explicándose por otra parte cómo los extranjeros negociantes en cereales son tan expléndidos y generosos que se molestan en traer á España trigos y harinas para después venderlos perdiendo, nada más lógico se suponga que tan raras circunstancias no reconocen otra causa que la falta de pago de los derechos arancelarios. (I).

Por tanto, la adopción de las disposiciones conducentes para impedir el fraude darán desde luego resultados tangibles y provechosos para los intereses del Tesoro y los de los labradores de buena fe.

Al propio fin será tambien conveniente que se cumplan con todo rigor las plausibles y previsoras disposiciones contenidas en la Real orden de 28 de Febrero de 1895 , sobre intervención de las corporaciones agrícolas y mercantiles; y por último limitar la entrada

(1) El infatigable Senador castellano Sr. Cuesta y Santiago, es el que con mayor empeño é insistencia ha emprendido vigorosas campañas para combatir el contrabando de trigos y harinas. 
de cereales, harinas, salvados y legumbres que sean necesarios á cuatro puertos en las cóstas del Mediterráneo y dos en las del Océano y Cantábrico, para que pueda atenderse mejor á la vigilancia, inspección é intervención, y evitar fraudes sensibles en perjuicio del Tesoro público y de la producción nacional.

Abrir y consolidar los mercados de Cuba, Puerto-Rico y Filipinas para los trigos y harinas nacionales.

Derogado, como ya afortunadamente lo fué, el convenio comercial entre los EstadosUnidos y las Antillas españolas, antes de contraer en definitiva nuevos compromisos internacionales debe ser consultada la opinión de las Corporaciones agricolas y fabriles del pais; oir las razones en que se apoyan, estudiar con el mayor detenimiento y favorecer la situación critica porque atraviesan los labradores y fabricantes de harinas.

Necesario es reconocer que en las referidas Antillas hay cuantiosos intereses, como los que representan los azúcares y los tabacos (además de los no menos importantes y preferentes relacionados con la Administración pública), los cuales no conviene desatender, sino harmonizar con los de la madre 
pátria, para el mayor desarrollo y prosperidad de todos los elementos hermanos (I).

Todo el mundo reconoce que en los mercados de Cuba, Puerto Rico y Filipinas, pueden hallar mucho alivio los productores é industriales peninsulares. La Isla de Cuba con millón y medio de habitantes, puede consumir diariamente, en circunstancias normales, 1.000 sacos de harina que á fin de año, suponen más de un millón de fanegas de trigo, y un ingreso de 12 ó 14 millones de pesetas en oro. Pues bien, una vez restablecidas y consolidadas las relaciones mercantiles que hubo hasta $10^{\circ}$ de Enero de 1892 , los harineros podrian dar mayor desarrollo 2 sus industrias, atraer á la peninsula cantidades considerables de tan preciado metal, y el trigo alcanzar mayor precio que el reducido que hoy tiene.

Si importante es el mercado de Cuba y Puerto Rico para las harinas peninsulares, no lo es menos el de las Islas Filipinas, pues con cinco millones de habitantes (2), el consumo de pan de harina de trigo, puede llegar

(1) Procurando evitar, al propio tiempo, todo motivo y aun todo pretexto para contiendas estériles J luchas sangrientas que no dejan en pós de sí más que odios, luto, desolación y ruina.

(2) De los que unos 4 millones son de orígen español. 
á ser mayor aún que en nuestras Antillas americanas, pues todos los envios que se hacen desde el puerto de San Francisco de California, podrian salir tambien de España, si los especuladores y fabricantes de harinas (á quienes más que al Gobierno corresponde la iniciativa), llegasen á establecer y sostener el tráfico en el referido archipiélago.

Conviene, pues, estimular el tráfico de harinas, imitando en este punto el ejemplo de Francia y Austria-Hungria, porque con la demanda de la harina aumentará también la del trigo, y éste cereal podrá reconquistar más fácilmente su justo precio.

A tal fin estimamos necesario:

1. Conceder aumento en las primas á los que exporten harinas nacionales con destino à nuestras posesiones de Ultramar; cuyo aumento deberá ser satisfecho ó compensado al verificar el adeudo de importación en las Aduanas respectivas.

2.. No gravar con mayores derechos arancelarios que los establecidos para los pro. ductos extranjeros (ni aún por razón de impuesto transitorio ó de guerra), à los trigos y barinas nacionales que se importen en Cuba, Puerto Rico y Filipinas; y en el caso de establecer alguna diferencia será siempre à favor de los productos nacionales.

Las fábricas de harinas del interior, particularmente las de Castilla y Aragón, en las 
que antes se elaboraban géneros muy superiores y se pagaban jornales crecidos cuando en ellas todo era movimiento y vida, se encuentran en la actualidad casi paralizadas y algunas cerradas, sin hallar los dueños quien las arriende, por no poder sostener la com. petencia con las de Cataluña que compran baratos los trigos extranjeros, con los cuales surten á muchos centros consumidores. Los fabricantes del litoral para enviar harinas á nuestras posesiones de Ultramar, se hallan en condiciones más ventajosas que los del interior, porque se evitan los gastos. y retrasos de los transportes terrestres.

Lógico y natural, y hasta patriótico entendemos habrá de parecer á todos, que los. productos de la madre pátria que se consuman en nuestras posesiones ultramarinas, disfruten de más ventajas que los procedentes del extranjero.

Al propio tiempo, es preciso adoptar las precauciones conducentes para que las harinas que de España se manden á las referidas Islas, si han de disfrutar las ventajas insinuadas, sean elaboradas con trigo nacional exclusivamente, evitando el antipatriótico espectáculo de remesar harinas con marcas españolas las procedentes de trigos extranjeros.

Asi, pues, los productos peninsulares que se envien à Cuba, Puerto Rico ó a Filipinas, 
deberán ir acompañados de la oportuna nota ó declaración, en la que se exprese con toda claridad la procedencia y destino de la mercancia, cuya declaración deberá ser comprobada con la mayor escrupulosidad por el personal administrativo que al efecto se designe; estableciendo fuertes multas y responsabilidades para los remitentes y consignarios que declaren y apliquen tarifas de harinas ó cereales nacionales á los que fueren extranjeros, concediendo además á los denunciantes el 50 por 100 de las multas que se impongan á los infractores. 



\section{CAPITULO III.}

De la Ganaderia.

1. Constituye un ramo de los más importantes para el desarrollo de la agricultura.

2. Estadistica pecuaria.

3. Deslinde de servidumbres pecuarias.

4. Conservación y fomento del arbolado.

5. Conveniencia de que se declaren de común aprovechamiento las barbecheras y rastrojeras.-Responsabilidad civil á los ganaderos por los daños que ocasionen sus ganados.Débense harmonizar los intereses de la agricultura y ganaderia.

6. De los animales dañinos.-Necesidad de su extinción y de la publicación del reglamento que los determine; asi como también las recompensas que hayan de otorgarse á los matadores de aquellos.

7. De los pastores.-Importancia del cargo.-Profesión injústamente menospreciada.-Recompensa que merece, y cuya concesión incumbe al Estado.

Constituye un ramo de los más importantes para el desarrollo de la agricultura.

La riqueza pecuaria constituye en España uno de los elementos más indispensables á la vida y una de las principables bases de 
la agricultura, no solo por lo que afecta á la explotación de sus nutritivas carnes, esquisitas mantecas, leche, quesos, lanas, pieles, etc., sino porque es un auxiliar poderosisimo del hombre para los transportes, y muy en particular para las múltiples, diversas y complicadas labores agricolas, pues á pesar de los muchos adelantos conseguidos en la aplicación del vapor, de la electricidad, máquinas y artefactos para usos agrícolas.é industriales, no es posible por ahora, y quizá no lo será tampoco en mucho tiempo, prescindir de su valioso y eficaz concurso; y por ser además el agente productor de abonos de que tanta necesidad tiene el esquilmado suelo de nuestra nación.

Tan importantisimo ramo de la riqueza pública española comprende toda clase de ganados, desde el caballar, mular, asnal, vacuno, lanar, cabrío, camellos, etc., ya sean de labor, granjeria, lujo ó de recreo, hasta las aves de corral y las de palomar que tanto benefician con sus huevos, crias é in mejorables abonos.

Las riquezas agricola y pecuaria deben asociarse y caminar unisonas como verdaderas hermanas, estrechar su largo y continuado paralelismo hasta llegar à un enlace harmónico y reciproco para la consecución de las reformas que puedan favorecer los intereses de una y otra. 
Sin el valioso apoyo de los ganados no sería posible practicar las labores con la perfección necesaria, porque son el auxiliar más poderoso para el trabajo inteligente del hombre, ni podria subsistir la agricultura; pues es sabido que uno de los factores que más contribuyen a la ruina de ésta, es la carencia de abonos naturales que son tan precisos para fertilizar y devolver a la tierra los principios nutritivos que las plantas extraen de ella; por lo cual muchos labradores no òlvidan los antiguos adagios: la oveja con la reja; antes $\sin$ orejas que sin ovejas, ni el sábio aforismo de Columela: "quien mucho ganado cría, sáca fruto á su alqueria;-al par que poco avanza, quien solo tiene labranza».

Como en Suiza, Bélgica y Holanda, en Asturias, Galicia y aún Santander y las Vascongadas predomina la ganadería á la agricultura. Una sola vaca suele ser el apoyo principal y casi único de que disponen para su subsistencia numerosas familias pobres, y la ganadería contribuye à que la emigración no sea mayor en tan importantes comarcas españulas.

La riqueza pecuaria, base fundamental de la agricultura merece el más decidido a poyo por parte de los Poderes públicos, en la seguridad que las disposiciones conducentes para favorecer la primera, serán ventajosas también al fomento de la segunda. A 
continuación detallaremos las que conceptuamos más viables y eficaces.

\section{Estadística pecuaria.}

Precisar con exactitud el número ó unidades de cada clase de ganados es tarea difícil, porque no existe catastro ni estadística alguna que lo determine.

Todos sabemos por ser una verdad triste y palmaria, que la ganadería se encuentra en visible postración y camina en decadencia progresiva, que existe desigualdad notoria en su tributación; el consumo de carnes disminuye; el precio de los ganados en baja constante; la exportación decrece; que urge aplicar los remedios conducentes á tantos males como le acumulan sobre la riqueza pecuaria; y que una estadística minuciosa y exacta debe ser la base para todo cálculo y operación ulterior.

Según el catastro verificado por el Marqués de la Ensenada á mediados del siglo anterior, existian en España 32 millones de cabezas de ganado de todas clases. De los datos suministrados por la Administración resulta que la riqueza pecuaria amillarada en España no llega siquiera á 2 I millones de cabezas ó unidades, cifra en verdad desconsoladora, y que de ser cierta sería una prueba bien inequivoca de la ruina y decadencia de 
tan importante ramo de nuestra riqueza nacional.

Afortunadamente no deben ser muy exactos los datos mencionados, pues según el censo de la ganadería hecho en I885 por la Junta general de estadistica, aparece con la halagüeña cifra de 36 millones (1) la que en verdad, nos parece algo exagerada, y porque según la Junta Consultiva agronómica, el referido censo es sólo de 25 millones.

Estamos, pues, sin conocer el número exacto de cada clase de ganados existentes en España; y un catastro ó amillaramiento de la riqueza pecuaria en el que se precise además la unidad y especies, su procedencia, destino, aptitudes, funciones ú objeto á que estén destinados, gastos, productos, y su valor en venta y renta es una necesidad que

(1)

\section{ESPECIES}

Vacuno.

Caballar.

Mular.

Asnal.

Cerda.

Lanar.

Cabrio.

Colmenar.
Número.

$2.697,537$

626,861

990,409

$1.265,207$

4.161, 182

21.322,370

$4.381,716$

776,404

$36.221,586$

Total. 
se impone para que sirva de cimiento, sobre el que habrá de apoyarse toda medida justa y equitativa.

Para llevarle á fecto podría acordarse la distribución á domicilio de cédulas impresas, con una nota ó advertencia aclaratoria al pié de cada una de las mismas con el objeto de evitar dudas y cubrirlas con mayor facilidad, á todas las personas que posean, administren, ó se hallen encargadas de camellos y de ganado caballar, mular, asnal, vacuno, lanar, cabrio y de cerda, de colmenas, palomas y gusanos de seda. La unidad para apreciar la riqueza pecuaria deberá ser en los ganados la cabeza, en las palomas el par, en las colmenas el vaso y en los gusanos de seda el grano de simiente avivada (I).

La distribución de las cédulas duplicadas podría hacerse en la segunda quincena de Diciembre, y para devolverlas y presentarlas en las Secretarias de los Ayuntamientos respectivos, cubiertas en la forma insinuada el día 3 I del propio mes, cuya época nos parece

(1) Así se estableció para su evaluación por el art. 117 del reglamento de 10 de Diciembre de 1878. Por la regla 11 del reglamento general vigente para la contribución de inmuebles, cultivo y ganadería de 30 de Septiembre de 1885 se mandó tener en cuenta la circular doctrinal de la Dirección general de Contribuciones de 16 del referido Diciembre. 
la más á propósito, en razón á que los ganados trashumantes y trasteminantes suelen permanecer fijos en los montes y sitios donde pasan las invernadas, y ser por consiguiente más fácil la comprobación. Además es cuando precisamente (exceptuando las crias) el número de cabezas de garado es más reducido, puesto que muchos ganaderos á la entrada del invierno acostumbran á vender las reses que menos utilizan, á fin de evitarse los muchos gastos que ocasiona la manutención á pienso en los apriscos, ó los pastos de monte por falta de yerbas y abrigo en las tierras labrantías durante los meses crudos del invierno; y aun cuando la cifra total no resultase tan elevada como si se efectuara en el mes de Junio, se caminaria sobre firme, sin cálculos ilusorios, evitando muchas molestias y gravámenes á los dueños de los ganados y el expedienteo consiguiente á los recaudadores, Agentes, Ayuntamientos y Juntas periciales, para la declaración del apremio y deslinde de fincas, ó de partidas fallidas que en muchos casos resultan por la pérdida; muerte y venta de ganados; y lo que también es sensible, el tener que pagar por tal circunstancia con otros bienes la contribución impuesta á la ganadería los que tienen amillarada riqueza rústica ó urbana, debido á lo que no pueden resultar insolventes. Por otra parte, en la época indicada es cuando menos 
apremiantes son las labores agricolas; y siendo labradores la inmensa mayoria de los individuos que en los pueblos constituyen las supradichas Corporaciones, podrán atender mejor al puntual cumplimiento de su misión.

A los que por cualquier circunstancia improvista no les fuere posible, presentar las cédulas ó relaciones el 31 de Diciembre, lo verificarán sin falta alguna antes del 8 de Enero siguiente; pero los datos que se consignen habrán de contraerse al citado día 31.

Durante los dias restantes del referido mes de Enero procederán los Ayuntamientos y Juntas ó Comisiones respectivas al exámen, comprobación y exclarecimiento de las relaciones presentadas, con la cooperación de los empleados del Municipio, capataces de cultivo, profesores de instrucción primaria y de cuantos auxiliares fueren necesarios.

En el mes de Febrero se llevarà à efecto en todos los términos municipales un cuaderno ó catastro minucioso y detallado de la riqueza pecuaria, consignando en él todos los datos y pormenores de las cédulas declaratorias, y á su final el oportuno resúmen, á fin de que desde el día $10^{\circ}$ al 15 de Marzo y sin necesidad de anuncios ó edictos se halle expuesto al público en todas las Secretarias municipales, pueda oirse de agravios y delegar la Junta provincial, si lo estimare conveviente en los empleados del ramo de montes, 
de Hacienda ú otras personas de reconocida probidad para que pasen á cada partido judicial á inspeccionar las operaciones estadisticas.

Resueltas en la segunda quincena de Marzo las reclamaciones presentadas, se remitirán con el expresado documento à la Junta provincial el día $1 .^{\circ}$ de Abril, acompañando además una Memoria suscrita de las operaciones practicadas y resultados obtenidos para el mejor éxito de la estadistica pecuaria. Cualquier individuo de la Junta ó Comisión municipal, podrá hacer las observaciones que tenga por conveniente, las cuales constarán en la Memoria, que deberá ser autorizada por todos los Vocales que constituyan aquella, como también el catastro, y demás documen-. tos relacionados con las operaciones citadas.

Todos los obligados á llenar las cédulas, que no lo verifiquen, se nieguen á facilitar los datos necesarios, para ello, ó los dieren inexactos; como también los funcionarios públicos y demás personas que por razón de sus cargos deben intervenir en las operaciones estadisticas mencionadas que faltaren al cumplimiento de sus deberes, serán corregidos con multas de 25 á 100 pesetas, las que harán efectivas en papel de pagos al Estado, sin perjuicio de las demás medidas coercitivas que correspondan, según la gravedad ó importancia de cada caso. 
La Junta provincial compuesta de las personas ya mencionadas (1) y de la cual podrá también formar parte el Ingeniero Jefe de Montes, examinará escrupulosamente los catastros ó cuadernos y demás documentos recibidos, consultando los antecedentes que estime precisos, y resueltas las alzadas interpuestas (2) formará además el censo ó catastro de riqueza pecuaria de la provincia para elevarle al Ministerio de Fomento antes del I 5 de Mayo.

Recibidos en el expresado Ministerio los documentos de que hacemos mérito, procederá con la cooperación de la Junta Agronómica, la Facultativa de Montes y la Asociación de ganaderos á formalizar el censo general de la riqueza pecuaria española para publicarle, si posible fuere, el dia $I .^{\circ}$ de Julio.

Las rectificaciones sucesivas se llevarán á efecto cada diez años, con separación é independencia de las relativas á la imposición $\mathrm{y}$ cobranza de cuotas que por contribución corresponda á la repetida riqueza, las cuales se verificarán todos los años, á la vez que las de la riqueza rústica y urbana.

(1) En la Parte 1. ${ }^{\mathrm{a}}$ cap. VI.

(2) Para los efectos de la contribución correspondiente á la riqueza pecuaria. 
Deslinde de servidumbres pecuarias.

Las intrusiones y usurpaciones cometidas en las servidumbres pecuarias originan en parte la escasez de pastos, y para el aprovechamiento de los mismos son un obstáculo que dificulta ostensiblemente el paso de los ganados de unas á otras zonas.

Muchos dueños de propiedades contigu as á las vias pecuarias y los que no lo son, en la creencia errónea de que ejercitan un acto no ya punible, sinó hasta un derecho, las roturan para destinarlas, unos al cultivo de cereales y otros hasta para plantio de viñedo; lo cual produce aunque en muy raros casos, reclamaciones y demandas, de las que por evitarse gastos y disgustos, tienen que desistir los ganaderos, con perjuicio de sus intereses y de tan importante ramo de riqueza nacional. Y no solamente se dificulta, con tales abusos, el paso al ganado, trashumante y trasterminante, sinó que tambien se perjudica al estante por la falta de pastos y la de veredas que le daban acceso de unas cañadas á - otras y á los abrevaderos que tan necesarios son para el lavado de lanas y dar de beber á los ganados sin ocasionar daños, en particular durante la época de los fuertes calores, y que merced á tales detentaciones algunos 
han desaparecido, y otros han quedado reducidos á una parte insignificante, tanto en anchura comoen extensión de lo que antes eran.

Varias disposiciones se han publicado para la conservación de las vias pecuarias, entre otras la ley de 21 de Octubre de 1820 ; Real decreto de 23 de Septiembre de 1836 y Reales órdenes de 24 de Febrero de 1839 y i3 de Octubre de 1844 ; pero todas sin resultado alguno para el fomento de la riqueza pecuaria.

Tampoco se obtuvo mejor resultado con la publicación del Real decreto de 3 de Marzo de 1877 por más que en él se establecieron reglas claras y concretas para deslindar las servidumbres pecuarias, y evitar nuevos abusos. Tan laudables propósitos no han sido secundados, como merecian, por los funcionarios que debieran intervenir los deslindes, ni aun por los mismos ganaderos.

La experiencia demostró que para llevar á efecto tan interesante servicio no fué suficiente el precepto escrito, ni el interés que su cumplimiento reportaria á la riqueza pecuaria, y que eran necesarias disposiciones más apremiantes $y$, aunque sensible, una sanción penal bien definida para los contraventores.

A tal fin y como complemento del Real decreto ya citado, se publicó el de 13 de Agosto de 1892 con el reglamento dictado para su. 
ejecución. En el primero se determinó la anchura de las servidumbres pecuarias (I) y el personal á quien corresponde la vigilancia de las mismas, y la conservación y mejora de su arbolado en los montes públicos; por el segundo se dictaron prevenciones claras y terminantes para el deslinde de las propias vías pecuarias, se hizo obligatorio el amojonamiento, y se estableció además la penalidad contra los intrusos y usurpadores.

Todo, pues, parecía aclarado y previsto en el Real decreto y reglamento últimamente referidos; el amojonamiento para evitar que los usurpadores reincidan pretextando desconocer sus linderos, y se llegó á confiar que su

(1) Art. 12. Las vias pecuarias necesarias para la conservación de la Cabaña española y el tráfico de reses son: cañadas, cordeles, veredas, coladas, abrevaderos, descansaderos y los pasos. La anchura de las cañadas es de 75,23 metros 90 varas castellanas; la de los cordeles 37,61 metros ( 45 varas); la de las veredas es de 20,39 metros (25 varas); ta delas coladas, así como la extensión de los abrevaderos, es indeterminada; los pasos son las servidumbres que tienen algunas fincas, para que por ellas, levantados los frutos, pneden cruzar los ganados.»

Lo propio disponia la ley 5." art. 22 del tit. 27 libro 7.0 de la Novísima Recopilación. En los años 1589, 1603 y 1609 se establecieron penas contra los usurpadores de cañadas y demás vías públicas, y se dispuso que los ganados pudieran pacer libremente lo que en ellas estnviese sembrado 6 nacido. 
exacto cumplimiento sería en breve un hecho verdad, del que tantos beneficios pudiera reportar á la ganaderia. No ha sucedido así (I); sin embargo de haber transcurrido 3 años, no sabemos que siquiera se haya intentado dar principio en ningun término tan indispensables operaciones.

Urge llevarlas á cabo, y para conseguirlo conceptuamos que sería conveniente designar un plazo breve para dar principio al deslinde y amojonamiento de todas las servidumbres pecuarias, tanto las de carácter general como las de carácter local; y otro prudencial y perentorio para la completa terminación de las mismas, en la forma prevenida en el título III del reglamento últimamente indicado, con el objeto de que la Asociación general de Ganaderos, auxiliada por los Cuerpos de Ingenieros de Montes y Agrónomos proceda después con la mayor premura, á demarcarlas en un plano ó mapa á fin de que sirva de consulta en cuantas dudas y

(1) Lo cual corrobora cuanto consignamos en la Parte 1.' cap. III y demuestra que de nada sirve el dictar sabias y acertadas disposieiones, como las de que nos ocupamos, si después rio se cumplen; lo cual redunda además en mengua y desdoro del principio ie Autoridad, de los encargados del cumplimiento de aquellas y en perjuicio del buen servicio público. 
reclamaciones que relativas al particular, pudieran suscitarse.

El plazo que para uno y otro caso se establezca, no deberá ser prorrogado sinó por circunstancias especiales debidamente justificadas, y siempre á solicitud de los encargados de llevar á efectolas precitadas disposiciones, y transcurrido que fuese, exigir, pero con todo rigor, sin consideración alguna, fuertes multas á los morosos; así como tambien conceder menciones honorificas, sin perjuicio de las demás recompensas en su dia acuerde el Gobierno à los que más se hayan distinguido por su probidad, desinterés y celo para el mejor desempeño de sus respectivas funciones.

Lo propio debiera establecerse para el deslinde y amojonamiento de los caminos vecinales (I), hoy obstruidos en su mayor parte, en perjuicio evidente del tránsito público,

(1) El Real decreto de 7 de Abril de 1848 que dictó reglas sobre la construcción, conservación y mejora de referidos caminos. los clasificó segun su importancia, en caminos de primero y segundo órden.

La ley de 28 de Abril de 1819 fijỏ en 18 piẻs el márimum de la anchura de los caminos vecinales. Estos hoy están equiparados á las carreteras de tercer orden J se sujetan á la ley especial de carreteras de 4 de $\mathbf{I} a$ yo de 1877. La dimensión estará en harmonia con la importancia del camino, sin que pueda exceder aquella de 18 piés ( 5,02 metros). 
de los intereses agrícolas, y muy singularmente de la ganadería, la que hoy, debido á tales usurpaciones, carece de los sabrosos y abundantes pastos que antes se criaban en los márgenes, cunetas, linderas y vallados de aquellos; y una vez deslindadas y amojonadas todas las vias de comunicación y servidumbres pecuarias, encargar su vigilancia á la Guardia civil, capataces de cultivo y guardas locales; y su inspección á los Ingenieros de Montes y Asociación general de Ganaderos, á fin de que se conserven siempre expeditas: y no creemos exagerar si afirmamos que la ley ó disposición que llevara á la práctica los fines que mencionamos constituiría por sí sóla uno de los medios mas conducentes y eficaces para fomentar la riqueza pecuaria española.

Conservación y fomento del arbolado.

Que el arbolado mas que útil es absolutamente necesario para todo cuanto concierne al interés agrícola, social, económico y administrativo, no hace falta demostrarlo, porque así está reconocido por todos.

Por fortuna se ván ya persuadiendo muchos labradores que dedicando al cultivo de cereales los terrenos poblados de bosques, se obtienen grandes productos en las primeras 
cosechas, pero que después viene la pérdida de las substancias fertilizantes, y como es consiguiente el considerable descenso de los mismos productos, y lo que es peor, las calamidades por efecto de las prolongadas sequias unas reces, yotras por terribles inundaciones, las que ocasionan en muchos casos desgracias personales, fiebres palúdicas y aún epidemias graves por la falta de oxigeno y aroma que purifica la atmósfera, además de los considerables deterioros en las propiedades.

Los àrboles, ya sean frutales, de sombra ó maderables modifican las condiciones climatológicas de las localidades; mitigan la fuerza de vientos; oxigenan la atmósfera; sus raices dán al suelo cierta cohexión para resistir los aluviones, y distribuyen de un modo uniforme los efectos de los distintos fenómenos meteorológicos.

"La sociedad entera está interesada en la replantación progresiva, y en el entretenimiento de los arbolados que proporcionan las maderas necesarias para la construcción y reparo de los edificios; que suministran las leñas y carbones indispensables para los usos de la vida; que son los conductores naturales de las lluvias; que alimentán la vegetación y aseguran las cosechas; que ofrecen sombra y frescura a los viajeros fatigados, y que en fin, hacen habitables los campos, 
desiertos cuando no gozan de este beneficio (1).

Por consecuencia de las leyes desamortizadoras fueron rápidamente roturados muchos montes, dehesas y prados que antes facilitaban pasto y albergue á los ganados durante los meses de invierno, cuyo disfrute era gratuito, ó cuando más á un tipo módico regulado por la ley; mientras que ahora en los montes que subsisten de propiedad particular lo es á otro tipo muy diferente establecido por los mismos propietarios.

Lamentables sucesos de todos conocidos á raiz de la titulada revolución setembrina; fueron la causa de que se realizasen devastaciones en extremo deplorables, escándalosas talas; muchos montes y bosques fueron descuajados, y que ante la impotencia de las leyes y de la Administración para poner coto á tales abusos, quedaron impunes la codicia y audacia de los taladores.

Aún en la actualidad, con ser bastante severa la sanción penal establecida en la legislación vigente de montes (2), se cometen roturaciones excesivas, intrusiones arbitrarias á las que es necesario poner coto, si

(1) Instruceión circulada á los Gobernadores civiles por Real decreto de 30 de Noviembre de 1833.

(2) Aprobada por Real decreto de 8 de Mayo de 1884 . 
se quiere evitar la total ruina de los montes. públicos (I).

Si no fuera por los montes no podría apenas subsistir la ganaderia, pues además. del abrigo que tanto como el alimento necesita en los dias fríos y desapacibles, producen con su eterna alfombra de verdura, yerbas sanas y aperitivas, sin las cuales seria preciso alimentar á los ganados con pienso en los establos ó apriscos, medio mucho más molesto y costoso.

Todas las naciones se preocupan del porvenir de sus montes y arbolados, considerándoles como auxiliar eficaz de la agricultura y de la ganadería; y como elemento valioso para la salud pública.

Al Estado, pues, corresponde conservar todos los montes públicos existentes, las dehesas boyales y los terienos de común. aprovechamiento (2); asi como también

(1) Aquellos magnificos panoramas que con tan variado sinnúmero de árboles poblaban superficies considerables de terreno, no son hoy más que tristes y desiertos áridos peñascos, cimas desnudas y pendientes, siempre estériles é infructiferas, porque después de tres ó cuatro cosechas de cereales, se han persuadido los detentadores de aquellos que no son propios para el cultivo agrario.

(2) Sin perjuicio de que se otorgue á los Municipios la facultad de vender 0 conservar la propiedad de sus montes, á fin de utilizar, en el primer caso, el 
aumentar el establecimiento de prados naturales y artiticiales, y muy particularmente la repoblación de montes y plantios por medio de una ley protectora que ordene la formación de semilleros por zonas sin aumento de tributo en 15 ó 20 años, premiando á los pueblos y particulares que más plantaciones verifiquen y mejores resultados obtengan de la misma.

Conveniencia de que se declaren de común aprovechamiento los barbechos y las rastrojeras.--Responsabilidad civil á los ganaderos por los daños que ocasionen sus ganados.--Débense harmonizar los intereses de la agricultura y ganadería.

Los muchos privilegios de que venía disfrutando la ganadería en los siglos anteriores, y aún á principio del actual, motivaron reclamaciones por parte de muchos labradores, hasta que las Córtes de Cádiz publicaron su memorable decreto de 8 de Junio de I813, llamado de Acotamiento general de las tierras, restablecido en 18 de Septiembre

precio de la venta en la fundación de Bancos agrícolas, para acudir en auxilio de los cultivadores; conforme al importante proyecto de ley del Sr. Torre Minguez. 
de 1836 , por el cual se han declarado cerradas y acotadas todas las de propiedad particular, aunque no lo estén materialmente; se proclamó la facultad de los propietarios y de los mismos ganaderos para administrar y disponer libremente de sus respectivos intereses, y se declaró libre el tráfico en el interior de la Monarquia.

La citada disposición fué altamente beneficiosa para la agricultura, porque destruyó en absoluto los antiguos privilegios concedidos á la ganaderia; pero á la vez creó otros en favor de aquélla, tan abusivos, en parte como los que se venian á derogar, y produjo una completa modificación en la ganadería, cuyo sostenimiento se hizo tan gravoso, que no encontrando quien la protegiera, se vieron obligados los dueños de aquélla á tomar la resolución extrema de enagenarla á precios sumamente reducidos.

La multitud de disposiciones que desde 1836 se ban dictado ( $\mathrm{i}$, todas encaminadas

(1) Reales decretos de 14 de Septiembre de 1838; 27 de Junio de 1839; 16 Febrero 1818: i2 Julio 1849; 10 Marzo 1852; 31 Marzo 1854; 4 Febrero 1857; 16 Febrero y 12 Mayo 1861; 3 Ilarzo 1877; 13 Agosto 1892; Instrucción 9 Noviembre 1858; ley 22 Agosto 1877; y muchísimas Reales órdenes y disposiviones desde el Fuero Juzgo, primer Código escrito de los españoles; leyes $5 .^{2}, 22,25,26$ y 27 , tit. $4 .^{\circ}$, lib. $8 .^{\circ}$, 
al fomento de $\tan$ importante ramo de riqueza pública es la mejor prueba de la notoria decadencia de la ganaderia y de la veracidad de nuestro aserto; como lo és también de que no disfruta mucha salud el individuo que se vé precisado á tomar medicinas con frecuencia; y de que no reune mucha solidez el edificio que necesita continuas reparaciones y puntales que le sostengan.

Harmonizar los intereses de la agricultura y ganaderia, es tarea bastante laboriosa y dificil; como lo és también harmonizar el capital y el trabajo, aún cuando aquellas importantisimas industrias se hallan intimamente enlazadas, como que ambas son gemelas, y no es posible la separación de la una sin que se resienta la otra; lo mismo que ocurre entre propietarios y obreros, puesto que es de todo punto imposible prescindir de ninguno de los dos podercsos elementos.

Desde que en 1836 se restableció el citado decreto de 1813 , han sido muchas las reclamaciones y demandas producidas contra la ganadería, las que han dado por resultado, en la generalidad de los pueblos rivalidades.

y posteriormente la Novisima Recopilación (ley $5 .{ }^{2}$, tít. 27 , lib. $7 .{ }^{\circ}$,) hasta el Cóäigo civil vigente arts. 499, $526,570,600$ al 603 inclusive, y otras cnya enumeración además de ociosa sería prolija en extremo. 
y enconos entre las dos clases hermanas, las cuales se han acrecentado desde que empezó a regir el Código penal de 1870 , cuyo artículo bi i ha venido en sintesis a establecer, que no es punible la entrada de ganado lanar en heredad ajena si el daño que cause no excede de cinco pesetas, aunque la entrada del garado sea intencional, ó por culpa ó negligencia de los dueños pastores ó criados (I)).

Como se vé existe una verdadera antimonia, una contradicción bien palmaria entre el repetido decreto de $1 \delta_{13}$ que continúa vigente y el expresado artículo 6i i del Código penal también vigente, la que conviene desaparezca para evitar duda é interpretaciones opuestas.

Aparte del espiritu restrictivo del ya citado decreto y del expansivo y tolerante que informa el artículo referido, si la virtud consiste en el justo medio, creemos que en

(1) Así y al interpretar el indicado artículo se reconoció por Sentencias del Tribunal Supremo de 8 y 31 de 0ctubre de 1881, cuya doctrina ha sido repetida y confirmada por Sentencias del mismo Tribunal de 9 de Abril de 1877 y 22 de Marzo de 1888; sin que el art. 619 del Código sea aplicable á los daños de la índole citada, los cuales se hallan exentos de la sanción penal; cuya jurisprudencia se ha fijado definitivamente por el referido más alto Tribunal de la nación, en Sentencia de 18 de Febrero de 1895. 
ningún caso mejor que en el presente para que sin menoscabo de hacendados y ganaderos, y colocar á unos y otros en lo equitativo y razonable, como asi mismo en la conveniencia reciproca que habria de reportarles, que del articulo 6I I de que nos ocupamos debieran suprimirse las palabras que exceda de 5 pesetas (I), á fin de que la propiedad sea más respetada, y evitar contiendas y demandas; y por considerar que todo el que ocasione un daño ya sea de mucha ó poca cuantía debe quedar obligado á su reparación.

Al propio tiempo y como una mejora interesante para la ganadería, de resultados. prácticos é inmediatos, sería la de modificar el decreto de 8 de Junio de 18 i3, concediéndola derecho al disfrute de pastos en todas las tierras abiertas ó que no estén cerradas materialmente y se hallen destinadas al cultivo de cereales, después que hayan sido levantadas las cosechas y mientras permanezcan en estado de barbecho; cuya concesión será exclusiva á los ganados de cada término municipal respectivo, pero quedando responsables los dueños de los mismos ganados á la indemnización de los daños y perjuicios que se ocasionen con motivo del aprovechamiento de pastos que abonará colectivamente la

(I) Conforme con el muy importante proyecto do ley del ex-Ministro de Gracia y Justicia Sr. Maura, publicado en la Gacela del 27 de Enero de 1895. 
ganaderia, sin perjuicio de que esta pueda reintegrarse despues del ganadero ó ganaderos causantes del daño, para lo cual tendrá derecho el propietario á reclamar de cualquiera de los ganaderos si no quisiere dirigirse á la colectividad.

En equivalencia del disfrute de que hacemos mérito podrá concederse á los Ayuntamientos la facultad de utilizar como arbitrio en sus presupuestos hasta 50 céntimos de peseta como máximum por cada cabeza de ganado; estableciendo así un no despreciable recurso en pro de las exhaustas arcas municipales, que habria de redundar de una manera más ó menos directa en beneficio de los propietarios.

No es que seamos partidarios de restricción alguna que coarte á los propietarios el derecho de disponer libremente de sus fincas, y de que las destinen al uso que más les acomode; pero entendemos que la reforma propuesta sería una reparación altamente plausible y ventajosa para la propiedad, hoy que las disposiciones insinuadas vienen a reconocer implicitamente un derecho a favor de los ganaderos para utilizar con el ganado lanar y aun el cabrío cuando la finca no tuviere arbolado, no solo los pastos de los barbechos y rastrojos sinó hasta los mismos sembrados en todos los casos que los daños que causen no excedan de 5 pesetas; de 
manera que hasta puede ocurrir que pastando los susodichos ganados uno y otro día lleguen á destrozar por completo las cosechas y resultar por tanto estériles los sacrificios de los propietarios.

$\mathrm{Si}$ como acostumbran algunos terratenientes que por evitarse gastos de tapias y vallados acotan sus propiedades para que sean más respetadas, nada consiguen si los pastores no proceden de buena fé ó quieren burlarse colocándose sobre los mismos cotos para ver impasibles los daños que ocasionen las ovejas y cabras, puesto que el caso de simple acotamiento no equivale al de cercado ó cerrado para incurrir en la falta prevista y penada en el número $40^{\circ}$ del artículo 607 del Código( $\mathrm{I}$; como tampoco consiguen cosa alguna diferentes propietarios de tierras labrantías, que desconociendo sus propios intereses, no ceden (como en algunos pueblos acostumbran) sus derechos al Ayunta. miento respectivo para que el valor de los pastos redunde en favor de los fondos municipales y exigen á los ganaderos precios elevados por el disfrute de aquellos; ni los que consienten que no se utilicen y haciendo caso omiso de la letra y espiritu del Código penal, promueven juicios y denuncias, cuyos

(1) Sentencia del Tribunal Supremo de 25 de Septiembre de 1889. 
resultados son casi siempre contraproducentes para los mismos demandantes.

Conviene, pues, armonizar los mútuos y reciprocos intereses de ambas riquezas, evitando demandas, pleitos, disgustos y hasta colisiones, y las discordias, ódios, rencillas y enemistades que se hacen mas patentes en las elecciones municipales para llevar cada bando su representación al Ayuntamiento, en el que si están en minoria los ganaderos las persecuciones son incesantes á la ganadería, cuyo sostenimiento se hace punto menos que imposible; pero si se truecan las circunstancias, y cuentan con mayoria, entónces se cometen en las propiedades multitud de abusos, á los que pocas reces se aplica el debido correctivo, máxime si cuentan aquellos con el valioso a poyo del Juzgado municipal.

¡Cuántos daños cometidos en las propiedades han quedado impunes por falta de pruebas (1) ó porque los perjudicados desconfiando del éxito de sus reclamaciones, y

(1) Pues sabido es que los pastores que ocasionan los daños con sus ganados y algunos testigos presenciales acostumbran á ocultar, en muchos casos, la verdad 6 a desfigurar los hechos: porque ya, por desgracia, no es ninguna novedad que en cierta clase de litigios y cuando uno de los medios de prueba sea el testifical principalmente, se valen algunos interesados, en estos tiempos en que la amistad se compra y la 
ante la inmunidad que a los ganados lanar y cabrío concede el Código penal en los casos de que hacemos mérito, desisten de sus derechos, que en ocasiones es el partido que resulta más ventajoso, ya que otros que intentan hacerlos valer, si es que por fin llegan á conseguirlo, ha sido à costa de sinsabores, gastos y disgustos.

Cierto que los juicios de faltas no son tan costosos desde que se puso en vigor la Ley del Timbre del Estado de 15 de Septiembre de 1892 , en cuyo artículo II 4 se estableció que el reintegro del papel invertido en los juicios de la clase indicada sea á razón de Io céntimos de peseta por cada pliego, en vez del de 2 pesetas que venía establecido anteriormente, de la propia manera que para las causas criminales de mayor gravedad é importancia. (I)

conciencia se vende, de artes maquiavélicas y de testigos poco escrupulosos para que prescindan del honor que se debe á la verdad y á la justicia del juramento y que los Tribunales en su rectitud é integridad, no obstante el espíritu ámplio de la ley y la facultad que para juzgar aquella les concede, careciendo de otros datos y pruebas, se ven precisados á aceptar como bueno, lo que es en algunos casos obra de la perfidia, la falsedad y el engaño.

(1) Por lo que consignamos gustosos tan provisora y equitativa reforma. 
Al que conforme al art. $60^{\circ}$ de la ley de Enjuiciamiento criminal se le reserva y deja expedita la acción civil para que pueda ejercitarla donde y de la manera que viere convenirle (1), le es preferible renunciar tal derecho á entablar nueva demanda, cuyo principio semeja algo á un plano inclinado, por cuya pendiente se desciende con bastante rapidez; pero la subida es por demás dificil y escabrosa, y en ella puede suceder lo que a las ovejas cuando pastan entre zarzas y matorrales, en cuyas afiladas garras han de quedar siempre algún vellón ó guedeja de lana de bastante más valor, por lo general, que el pasto utilizado.

Todos estos y otros inconvenientes que no enumeramos, ocurren entre los ganaderos en pequeña escala, como lo son la mayor parte de los que existen en nuestra naciòn, puesto que con la reforma de 1813 han desaparecido las antiguas Cabañas de Negreti, Escorial, la del Patrimonio y todas las demás que dieron tanto renombre á la ganadería española. Y no es que suceda en una ó dos localidades solamente, sino en la inmensa mayoría de los pueblos de España, cuyos

(1) Reclamar á les ganaderos en juicio verbal la indemnización de daños y perjuicios, ó interponer el oportuno interdicto de retener $\delta$ de recobrar. 
ecos apenas repercuten en los grandes centros de población, en los que no preocupa un estado tan critico y excepcional por ser en ellos casi completamente desconocido; pero por lo mismo que los pueblos son los más sufridos, los más propicios para acudir presurosos á la defensa de la patria, los que más contribuyen al sostenimiento de todos. los servicios públicos, y los que menos comodidades disfrutan, son igualmente dignos de protección por parte de los Gobiernos.

La reforma que proponemos es más que mera conveniencia una necesidad, en razón $\dot{a}$ que habiéndose roturado muchos montes, prados y aun eriales y el cultivo tan extenso que se ha dado á la vid, no quedan en muchos distritos municipales mas que las rastrojeras y barbecheras para alimentarse los. ganados, aunque no con la abundancia de yerbas que tenian, por el mayor esmero cultural en las tierras destinadas à cereales.

Por nuestra parte iriamos todavía más lejos haciendo extensiva tal concesión al viñedo en determinadas épocas del año, y con ciertas excepciones. Si al fin aprovechan los ganados las yerbas y la pámpana de las viñas, sin que en la mayor parte de los casos paguen por ello los ganaderos cantidad alguna; mientras que una vez establecido que los daños que causen los ganados en las fincas del término suran responsables todos 
los gat aderos del distuitu municipal de la clase que los hayan causado, quedando obligados á la indemnización inmediata, lejos de ser tal medida atentatoria al derecho de propiedad, vendría á concluir en una verdadera garantia en favor de los terranientes, ante los muchos abusos que hoy se cometen en sus propiedades; pero como nos parece que con cierta clase de reformas no conviene caminar de prisa para evitar tropiezos (1), esperamos con respecto al viñedo á que aquélla se imponga con el tiempo, después que se conozcan prácticamente los resultados tangibles y provechosos para las dos importantes ramas de riqueza pública, de la reforma ó concesion propuesta para el disfrute de los pastos en los barbechos y rastrojos, con cuya sencilla medida se prestará un buen servicio á la ganadería y á la propiedad, porque las tierras recibirian oportunamente las substancias fertilizantes del abono de los ganados, la riqueza pecuaria tendria mayor libertad para el disfrute de pastos en los barbechos y rastrojos, que màs por la necesidad que por emulación entre los pastores se

(1) Aun cuando se confie en la bondad de las mismas, á la manera que el que está en la obscuridad y necesita del auxilio de la luz no le es conveniente recibirla de repente, sinó por grados para evitar que el cambio brusco y exceso de aquélla le perjudique la vista. 
vén obligados á utilizar con aquella, aunque sea contra la voluntad de los dueños; de noche ó con celeridad, en perjuicio de las mismas fincas que recorren y de la misma ganaderia; se evitaban las muchas demandas y tasaciones periciales para apreciar si los pastos utilizados ó los daños inferidos en los sembrados, y los deterioros en el terreno ó en las labores practicadas valian ó nó más de 5 pesetas, que es el caballo de batalla en los numerosos juicios de faltas que con tal motivo diariamente se suscitan; y se evitaban por último antagonismos, odios, disgustos y otros inconvenientes en la generalidad de los pueblos de nuestra nación.

$Y$ no es que tal reforma haya sido vista solamente en la superficie ó en el buen deseo, sinó en el fondo de la realidad y analizada con el escalpelo de la experiencia; por lo que confiamosque contribuiria eficazmente á hermanar los intereses agricolas y pecuarios, $y$ al fomento y desarrollo de una y otra riqueza.

De los animales dañinos.-

Necesidad de su extinción y de la publicación del reglamento que los determine, así como también las recompensas que hayan de otorgarse á los matadores de aquellos.

La extinción de los animales dañinos es un servicio importante que merece preferente 
atención y celo, debiendo ponerse en práctica los medios conducentes para la consecución de dicho fin, puesto que asi lo reclama con insistencia imperiosa la conveniencia pública y el interés común de los pueblos, por ser una medida de seguridad personal, y protectora de la riqueza pecuaria.

Los osos, lobos, las zorras y otros animales fieros, tan perjudiciales al hombre, á los ganados y á los frutos, deben ser objeto de una incesante persecución y exterminio, para evitar desgracias personales, y pérdidas de ganados.

El oso, es una amenaza constante para la vida de las personas, en particular para los habitantes que pueblan las montañas y terrenos escabrosos, y un peligro permanente para los ganados, no respetando ni al vacuno, en el que ocasiona numerosas victimas.

El lobo, uno de los animales que tienen mayor afición a la carne, causa todos los dias algunos destrozos en los rebaños lanares, busca las majadas de los pastores, y devora todas las reses que encuentra antes de llevar la pieza que elige; es temible no solo por lo que come, sinó por los destrozos que ocasiona, especialmente en corrales y rediles. En su instinto de ferocidad ataca lo mismo á las ovejas que á las mulas y caballos y estando hambriento acosa á las mujeres y 
niños, y aún á los hombres; como así lo atestiguan multitud de ejemplos que, por no ser demasiado prolijos, no enumeramos.

La zorra, famosa por su astucia, come de todo con ansia, carne, huevos y frutos; pero donde ocasiona mayores destrozos, es en los gallineros, en los que todo lo arrasa, llevándose después cuanto puede. También destruye muchos conejos y sus crias en el campo, caza erizos y acomete a las avejas silvestres y á las avispas para sacar el panal y comerse la miel y la cera.

La ley de 9 de Julio de 1856 sobre privilegio de caza y pesca, y de conformidad al Real decreto de 3 de Mayo de 1834 para fomentar el exterminio de animales dañinos, estableció en su artículo 29 un premio á las personas que los presentáren muertos, consistente en 40 reales por cada lobo, 60 por cada loba; 8o estando preñada; 20 por cada lobezno; la mitad respectivamente por cada zorro, zorra ó zorrillo, y la cuarta parte también, respectivamente por las garduñas y demás animales menores expresados, tanto machos como hembras y sus crias.

La vigente ley de caza de 10 de Enero de 1879 en su articulo 39 declara libre la caza en los terrenos del Estado ó de los pueblos y en los trasjeros de propiedad particular no cerrados ó amojonados, de los animales dañinos que determinará el reglamento; y el 
articulo 40 preceptúa que los Alcaldes estimularán la persecución de las fieras y animales dañinos, ofreciendo recompensas pecuniarias á los que acrediten haberlos muerto, á cuyo fin incluirán entre sus gastos obligatorios, la correspondiente partida en el presupuesto municipal de cada año.

Pocos son los Alcaldes y Ayuntamientos que cumplen con tan terminante precepto; muchos presupuestos municipales se forman y aprueban sin incluir en ellos un sólo céntimo para tan importante objeto, y algunos de los posos Ayuntamientos que consignan una partida para simular el cumplimiento de la ley, abonan después cantidades tan insignificantes, que mas que premio parece un sarcasmo, con cuyo proceder la concesión de premios á los matadores de animales dañinos ha caido en desuso, y los cazadores y aficionados que antes les perseguian, faltos ahora de estímulo porque sus servicios no se premian, se han dedicado a otras ocupaciones, haciendo caso omiso de la persecución de aquellos, por lo cual se han reproducido considerablemente.

Para exterminar los animales dañinos se han establecido batidas y consignado premios en todas las naciones de Europa y en España que es tan necesaria la adopción de tan previsora medida, ya que el reglamento para la ejecución de la expresada ley de caza no se 
ha publicado aún, no obstante haber trascurrido 17 años desde la promulgación de esta, urge que el Gobierno le publique y determine con la debida claridad los animales que han de considerarse dañinos y la cantidad ó recompensa que haya de abonarse en cada caso; y que además ordene á los Gobernadores que no aprueben ningún presupuesto municipal sin que figure en él la partida necesaria para premiar en cada ejercicio económico à los matadores de animales dañinos con arreglo á las necesidades y circunstancias de cada localidad, á fin de que el sábio precepto de la ley sea, en lugar de letra muerta, una verdad práctica.

Si en algún caso excepcional no fuere suficiente el medio indicado, se dará cumplimiento al artículo 4I de la expresada ley, haciendo uso de los envenenamientos con las precauciones debidas, y cuidando además de que tengan efecto las batidas que sean precisas, aun cuando para ello sea necesario disponer de algunas fuerzas del Ejército ó de las reservas.

Los daños ocasionados por los osos, y principalmente por los lobos en las reses vacunas, lanares y cabrías, durante los últimos años, demuestran la necesidad apremiante de que los Ayuntamientos desplieguen mayor iniciativa para el exterminio de las fieras perjudiciales á los ganados, y que 
constituyen al propio tiempo un peligro constante para las personas, como también de que los Gobernadores civiles estimulen y obliguen á las referidas Corporaciones municipales á que adopten las disposiciones conducentes á tal fin; debiendo todos considerar un servicio importante para los intereses de la riqueza pecuaria el de la extinción de los animales dañinos.

\section{DE LOS PASTORES.}

Importancia del cargo.-Profesión injustamente menospreciada.-Recompensa que merece, y cuya concesión incumbe al Estado.

El cargo de pastor ó guarda de ganados, es de una importancia tal que nadie con razóc puede negar. El aumento ó disminución en los gastos y productos; el mejor ó peor estado de la ganadería, y mucho de cuanto concierne al fomento de la misma depende en ocasiones del mayor ó menor celo y pericia de los pastores. El más leve descuido, ya que no una mala intención por parte de los mismos, puede ocasionar considerables daños, reclamaciones, demandas y disgustos entre los propietarios perjudicados y los dueños de la ganaderia; á cuya indemnización inmediata se hallan estos obligados; lo cual nada más lógico y procedente, 
porque si solo fuesen responsables los conductores ó guardas de aquellos, quedarian impunes y sin indemnizar todos los daños que ocasionaren, puesto que casi siempre resultan insolventes por carecer de bienes de fortuna; y porque del pequeño jornal ó haber que disfrutan nada absolutamente pueden ahorrar, pues ni siquiera suelen tener para cubrir las atenciones más apremiantes de la vida; y como no hay cosa que excite y aliente más al mal que la impunidad, se cometerian seguramente mayores daños y abusos, de los que tenian que sobrevenir represalias y otros inconvenientes de consecuencias siempre funestas y desagradables.

Y no solamente vienen obligados los amos al resarcimiento de los daños que causen sus ganados, sino que también les comprende responsabilidad penal, conforme á las disposiciones del Código(I) y á la reforma de la

(1) Art. 613. Si los ganados se introdujeren de propósito ó por abandono ó negligencia de los dueños ó ganaderos, además de pagar las inultas expresadas en los artículos anteriores, sufrirán los dueños y ganaderos en sus respectivos casos, de uno á treinta dias de arresto, si no les correspondiera mayor pena conıo reos de hurto ó daño por voluntad 6 imprudencia.

Si reincidieran por tercera vez en el término de treinta dias, serán juzgados y penados como reos de hurto ó daño comprendidos en el libro $2{ }^{\circ}$ 
legislación penal de montes de 8 de Mayo de 1884 (I).

De manera que si se les considera comprendidos en el art. 6r 3 del Cćdigo penal, tienen que sufrir los mismos dueños de los ganados de uno á treinta dias de arresto, en el caso de que no les corresponda mayor pena como reos de daño por voluntad ó imprudencia. Cuando sin el consentimiento, y aun contra la voluntad expresa de sus amos tienen los pastores el descuido ó el capricho de hacer entrar ios ganados a pastar en algún monte público, y los dueños de estos fueren insolventes, lo cual puede muy bien suceder; en particular á los que nı poseen otra clase de riqueza, serán castigados con un día de arresto por cada 5 pesetas de multa de que sean responsables.

Por otra parte, los guardadores de ganados incurren también en responsabilidad criminal por los daños que con los mismos ocasionen, aun en el caso (poco frecuente por cierto) de que obren por obediencia á sus amos, cuya circunstancia no pueten alegar

(l) Los multados que fueren insolventes, serán castigados con un dia de arresto por cada 5 pesetas de multa de que deban responder. Cuando no llegue á 5 pesetas, serán castigados con un dia de arresto.

Por lo demás, responsalidades pecuniarias en favor de tercero serán castigados también con un dia de arresto por cada 5 pesetas.

CRISIS agrígola. 
en su favor porque la obediencia no se debe cuando además de no emanar de Autoridad alguna competente, se encamina á infringir algun precepto del Código. (1).

Todo lo cual corrobora nuestra téxis, y demuestra que no á todas personas se puede confiar un cargo de tanta importancia, para cuyo buen desempeño se requiere vocación, pericia y conciencia.

Moisés sábio legislador y caudillo del pueblo hebreo; el rey y profeta David; el valiente lusitano que lo mismo que Anibal hizo temblar á Roma, Viriato; el intrépido conquistador del Perú, Pizarro; el Pontífice Sixto V, $y$ otras esclarecidas lumbreras y figuras tan memorables en los fastos de la historia, que por sus excepcionales dotes de sabiduría, virtud, valor y prudencia han llegado á ocupar los primeros puestos y jerarquías de la tierra, han salido de tan humilde y sencilla clase. Sin embargo ninguna otra, en la actualidad, más postergada; es precisamente à la que se trata con mayor indiferencia y más censurable menosprecio. La alta consideración, que debida ásus merecimientos en otros. tiempos disfrutaba, háse trocado en injustificados desdenes y vilipendios, no obstante los.

(1) Sentencia del T. S. 21 de Junio 1892. (Gac. 15 Octubre id.). 
señalados servicios que prestan á tan importante ramo de riqueza pública. De cualquiera persona que parezca algo rústica, ó que se la quiera molestar con improperios, se dice: viene de guardar ovejas. ¡Cómo si tan noble profesión fuera incompatible con la virtud, idoneidad, honradez y laboriosidad! circunstancias que deben ser peculiares de todo hombre bien educado y amante del exacto cumplimiento de sus deberes.

Como justa y merecida recompensa, aunque no la suficiente para elevarla al grado de consideración social á que es acreedora, conceptuamos que la excepción del art. 69 caso $110^{\circ}$ de la ley de reclutamiento y reemplazo del Ejército de I I de Julio de 1885 para eximirse del servicio activo en los cuerpos armados los hijos de los propietarios, administradores, arrendatarios, mayorales y capataces despues de dos años de residencia en finca rural, beneficiada por la ley de 3 de Junio de i 868, y los demás mozos sorteables despues de habitar en ella por espacio de cuatro años consecutivos, debe hacerse extensiva y comprender igualmente á los hijos de los pastores, ó guardas de ganados, aun cuando no sea más que como á los comprendidos en el último caso citảdo, despues de llevar los padres de los mozos alistados cuatro años en el ejercicio consecutivo de la profesión indicada. 
La razón para haber concedido tal gracia en favor de lus mozos, cuyos padres vivan en finca rural distante de los centros de la población, la encontramos muy justificada, y conducente además al fomento de la agricultura; pero entendemos que lo estará mucho más aun en los hijos de los pastores, y con mayor motivo si ejercen la misma profesión que sus padres, pues los que habitan en fin. cas agricolas tendrán siquiera una casa ó edificio para albergarse y descansar por la noche con alguna comodidad, al abrigo de los Elementos, mientras que los pastores se hallan en todo tiempo más expuestos que aquellos á las inclemencias atmosféricas, en particular los guardadores de ganados trashumantes, que separados de sus familias, no suelen tener más que un misero chozo ó cabaña, sin condiciones para resistir la fuerza de los vientos, lluvias y nieves de los meses crudos del invierno, dormir siempre vestidos y las frugales viandas que les sirven de alimento tienen que tomarlas frias y sin condimentar. Pues bien, todas estas y otras muchas penalidades las llevan con resignación admirable, sin que la más leve queja salga de sus lábios.

¿Qué más se puede pedir, ni qué más se quiere de tan humilde y sufrida clase?

Creemos, pues, bien merecida y que debe otorgarse en su favor la recompensa 
mencionada, cuya concesión corresponde exclusivamente al Estado; más que gracia ó merced es una medida de equidad y justicia que habria de contribuir de un modo eficaz al fomento de la ganadería, y á que tan relegada clasé fuera más considerada y atendida que lo que lo es al presente.

¡Cuántos, entónces, no tendráná méngua como hoy sucede, desempeñar la profesión de pastores! y cuántos, lejos de aborrecerla, desearian ejercerla, aunque fuese por menos jornal todavia que en la actualidad, siquiera por lograr en favor de sus hijos, (como los braceros de fincas agricolas) lo que bien à su pesar no pueden de otra manera!

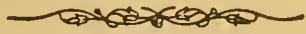





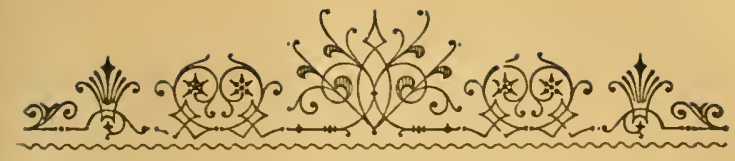

\section{PARTE TERCERA}

\section{MEDIOS COMPLEMENTARIOS}

\section{CAPITULO ÚNICO (I)}

1. La iniciativa individual.

2. Legislación y estadística agrícola.

3. Obras públicas.

4. Las vias de comunicación y los transportes de productos agricolas.

5. Los Pósitos y los Bancos agricolas.

6. Seguridad y policia rural.

7. Canales y pantanos.

8. De las minas.

9. El impuesto de Consumos.

10. Legislacion hipotecaria y de derechos reales.

11. Exposiciones nacionales, regionales $\mathrm{y}$ consulares.

12. Animales útiles y dañinos á la agricultura.

13. De los Veterinarios.

14. Indicación de otros varios.

(I) Además de los medios generales y particulares de que nos hemos ocupado, réstanos consignar aún algunos complementarios, que mencionamos en este capitulo con la mayor brevedad y concisión posible para no dar mayor extensión á la presente obra. 
La iniciativa individual.

El derecho á la vida es superior y anterior á todos los demás derechos, y el hombre debe ejercitarle sin tregua ni descanso por los medios lícitos y adecuados puestos á su alcance, y con arreglo á las fuerzas, necesidades y aptitudes que cada uno posea.

El hombre, pues, por muchas que sean las dificultades y por grandes los escollos $y$ obstáculos que encuentre en el camino de la vida, no debe arredrarse, ni retroceder en la via que le convenga seguir, aunque ésta se halle erizada de espinas y abrojos, así como. tampoco entregarse vencido à los accidentes. fortuitos, ó á las contrariedades, que muchas veces ceden á la resistencia más ó menos fuerte y tenaz que se les oponga, sin hacer frente y prestarse á la lucha con verdadera decisión y entereza para vencer esos mismos. escollos y obstáculos, cual valeroso y experto piloto cuando la tempestad amenaza sumergirle con su nave en la tenebrosa profundidad de los mares.

Por lo tanto, en las circunstancias tan críticas y excepcionales que atraviesa la riqueza agricola y pecuaria, los labradores, vitivinicultores y ganaderos, en vez de arredrarse, deben hacer frente á tantos males. como sufren, é intentar un esfuęrzo común 
y supremo para conseguir todas aquellas urgentes y salvadoras reformas que reclama su triste y angustiosa situación.

De aquellos félices tiempos en que además de ser buenas las cosechas el precio de trigo era el de II y I 2 pesetas fanega, y el de $4 \mathrm{y}$ aún de 5 el cántaro de vino, con muchas facilidades para las ventas que permitian á los labradores y viticultores atender desahogadamente al pago de tributos y al cultivo de la tierra, y dar por consiguiente más jornales y mejor remunerados en todas las épocas del año, hemos pasado á otro en que los productos agricolas se vén muy despreciados, por lo cual muchos propietarios se encuentran en una situación muy apurada y alarmante, $y$ en el duro trance de tener que abandonar los campos, en particular los viticultores que no pueden dar salida á sus productos, y cuando después de infinidad de molestias y sinsabores consiguen venderlos suelen ser á un precio que no recompensan siquiera los gastos de cultivo y ùe recolección, pero juos hemos de abandonar por completo en tan difíciles circunstancias?

Nó; porque si tal hiciéramos, los resultados serian todavía más funestos.

Es un absurdo cruzarse de brazos y esperarlo todo de la acción del Gobierno, como el individuo enfermo que se abandona asimismo y deja que el mal se apodere por 
completo de su naturaleza, confiando en el médico ó en la medicina para recobrar la salud pérdida, siendo así que además de los auxilios de la ciencia, debe él poner tambien oportunamente cuanto esté de su parte para combatir la dolenciá que le aqueja; y de la propia manera que el agricultor no debe confiar en el temporal exclusivamente para obtener buenas cosechas, sinó que él, por su parte, deberá practicar las labores conducentes a tal fin, y hacer uso con la debida oportunidad de abonos, riegos, limpieza de yerbas, destruir si le es posible, las plagas que se presenten, y todo cuanto además le corresponda, debiendo ayudarse para que Dios le ayude y para cumplir el divino precepto: Con el sudor de tu rostro comerás el pan (1), en vez de desdeñar el trabajo y deábandonarse ante las contrariedades de la vida.

Asi, pues, entre los diversos remedios que cabe aplicar para combatir los muchos males que lamentamos, algunos corresponden exclusiva y otros principalmente á la iniciativa privada, como lo relativo á las buenas prácticas de cultivo, conforme lo aconsejen y requieran los diversos terrenos y producciones de cada respectiva localidad, harmonizar los intereses de los propietarios con los de la clase jornalera, mantener las relaciones más

(1) Gen. III-19. 
cordiales entre los agricultores y ganaderos, (como también con los comerciantes é industriales) seguros de cosechas y ganados, fomento de intereses locales; sociedades para facilitar la salida y venta de productos agricolas y pecuarios en los mercados nacionales y extranjeros; adquisición directa y en ventajosas condiciones de cuantos artículos convinieren á los asociados, etc., etc.

Además al Gobierno tampoco le es posible abrir mercados siempre que lo desea, buscar compradores para todos los frutos y productos de la tierra, establecer mejoras en los cultivos, atender á la economia rural, ni à otros fines y servicios peculiares á la iniciativa privada.

El mejoramiento y bienestar de los agricultores depende en gran parte de su exclusiva iniciativa y de sus propios esfuerzos.

No obstante la actividad comercial y el espíritu de empresa que tanto distingue á los franceses M. Lebón atribuye las causas de la crisis industrial y comercial de Francia á la falta ó mala dirección de la iniciativa privadá; y con mayor fundamento puede atribuirse á la propia circunstancia, una de las causas principales de la actual crisis agricola y pecuaria en España, donde se carece en absoluto del saludable espíritu de asociación, y la más estóica indiferencia y censurable apatía imperan en los agricultores. 
Es, pues, necesario que los mismos agricultores se persuadan de su error, procuren asociarse cuanto antes, salir de su rutina $y$ apatia, y buscar por si mismos la manera de poner remedio á los muchos males que sufren, y para ello deben imitar la conducta de los belgas, alemanes y americanos, cuyo espiritu de asociación é instinto de exportación son admirables. Si el que más necesita es quien debe buscar primero, en este caso preciso es reconocer nos encontramos los españoles, y por lo tanto, sin perjuicio de las buenas labores y abonos, de utilizar para la siembra y cultivo, las plantas y semillas aplicables á cada terreno que en cada época tengan mayor aceptación y mejores precios, y de otras diversas prácticas útiles y provechosas, la iniciativa particular ó privada debe procurar adquirir buenas relaciones en los mercados nacionales, y más aún en los extranjeros, centros consumidores, industriales y con cuantas personas puedan facilitar la más ventajosa colocación á sus productos, los cuales deberán dar á conocer por representantes hijos de la respectiva comarca, agentes comerciales ó por los demás medios que estimen conducentes y eficaces, en particular los vinos, cuya riqueza es la que necesita mayor protección que las demás, y es la primera y más importante en lo que à la exportación atane, imitando al efecto el 
ejemplo de los viticultores de Austria y California, los que desde tan lejanos paises exportan con buen éxito vinos á Europa, á pesar de no disponer de tan buenas clases ni de medios mejores y más baratos para los transportes.

También conviene adaptarse á los tiempos y á lc que exijan las costumbres, sin olvidar que como dice Cantoni, el mundo no concluye en nuestra casa ni en nuestro pais; que en el comercio más que nuestros gustos y nuestras costumbres, debemos consultar los gustos y las costumbres de quienes hayan de consumir nuestros productos; y que según Jules Ferri: «Si politicamente no es posible estar aislado cuando se es fuerte, tampoco es posible nunca el aislamiento económico cuando se es rico».

Pocas veces ó ninguna se consigue llegar a] fin sir poner antes los medios; por consiguiente urge escogitar todos aquellos que se conceptúen más prácticos y viables para disminuir y si es posible extinguir los males que se oponen a nuestra regeneración agrícola, sin esperar á que el Gobierno lo dé todo hecho, ni à que otros lo consigan, porque el egoismo jamás levantó altos vuelos; como tampoco confiarlo al azar ó á la casualidad, pues si el agricultor descuida sus propios intereses y no pone siquiera aquello que buenamente está de su parte, no tendrá 
derecho á quejarse si los gobernantes no atienden como deben al fomento y desarrollo de la producción nacional; y para conjurar la actual crisis agraria la iniciativa pri vada debe contribuir tanto ó más que la acción del Estado.

\section{Legislación y estadística agrícola.}

Cual las aves por el aire y los peces en los rios y mares, asi se hallan esparcidas y diseminadas en nuestra vasta y complicada legislación, la multitud de disposiciones relativas á la riqueza agricola y pecuaria, sin que por estudios especiales que alguien haya hecho y por versado que se halle, creemos no podrá preciarse de conocer á fondo todo lo establecido respecto á la propiedad rural y á la ganadería; y asi como existe un Código civil, otro penal, otro militar, otro de comercio y se ha acordado proceder á formar otro económico-administrativo (I) se impone de una manera apremiante un Código rural en el que se hallen recopiladas todas las disposiciones preceptivas y aclaratorias, toda la doctrina establecida para la aplicación de las innumerables reclamaciones y

(1) Por Real decreto de 15 de Agosto de 1895, dictado con el objeto de reunir en un cuerpo de doctrina la legislación vigente de Hacienda pública. 
demandas suscitadas, todo ese cúmulo de reglas y preceptos sin órden y sin enlace que á veces chocan y se repelen unos á otros por la multiplicidad y elasticidad de aquellas, dictadas muchas veces más que por el estudio y las evoluciones de los tiempos, por las exigencias de la politica, sistemas abandonados, ó por conflictos del momento que reclamaban una solución inmediata; por lo cual existen leyes reformadas por decretos, éstos por Reales órdenes, y todo modificado por reglamentos y circulares que en vez de interpretar ciertos puntos dudosos han llevado por doquier la confusión y el desórden, ofreciendo resoluciones adaptables a todos los gustos y conveniencias, y que urge aclarar y recopilar debidamente, á fin de que puedan formar un conjunto armónico de reglas preestablecidas conforme con la legislación general entre nosotros vigente, y á todo lo demás que convenga establecer ó reformar para la mejora y progreso de tan importantísimos ramos de riqueza pública.

La necesidad de un Código rural en el que aparezcan recopiladas todas las disposiciones relativas á los acotamientos, aguas, arbolado, caminos, caza, daños, deslindes, frutos, ganaderia, impuestos, minas, montes, pesca, viñedo, vigilancia y cuanto concierne á la riqueza agricola y pecuaria, no es necsario encarecer para que proprietarios, colonos, 
obreros y ganaderos puedan conocer todos sus derechos y deberes, evitando divergencias, y dedicarse con más tranquilidad y provecho á las penosas faenas del campo.

De la propia manera es necesaria una estadistica verdad de producción y consumo, puesto que menos aún que conocer la legislación agricola y pecuaria, se sabe lo que se cosecha en cada uno de los diferentes productos de la tierra, lo que se consume, ni lo que se destina á la siembra, á las industrias y á la exportación, porque no se ha formado una estadística completa y fehaciente acerca de $\tan$ importante particular, pues las que se han publicado carecen de base y solo obedecen á un cálculo más ó menos aproximado.

Por tanto es necesaria la organización y publicación de la estadística mencionada, cuyo importanteservicio pudiera conferirse al Instituto Geográfico y Estadístico bajo la base de relaciones juradas suscritas por los cosecheros, labradores, ganaderos, fabricantes y expendedores, que serán comprobadas por los Ayuntamientos, y en caso de error ó sospecha fundada de haberse faltado a la verdad por las Juntas de partido encargadas de formar las Cartillas evaluatorias ( $r$ )

(1) Que se mencionan en la Parte 1.", cap. VI. 
para que sirva de fundamento a toda operación ulterior en beneficio de la agricultura y ganaderia.

\section{Obras públicas.}

Nuestras leyes vigentes son una rémora constante para la apertura de las vias públicas, porque dificultan mucho la construcción de caminos, carreteras, canales y lineas férreas; por lo cual ya hemos expuesto (1) la necesidad de simplificarlas para que los procedimientos resulten más breves, sencillos y económicos; y entretanto estimamos conveniente para la prosperidad de la agricultura:

Conceder, en vez de subvenciones para obras de utilidad priblica, indemnizaciones por las que hayan construido los particulares; debiendo los interesados participarlo con la antelación necesaria al Ministro de Fomento y al Gobernador civil de la provincia donde aquellas hayan de efectuarse, á fin de que puedan ejercer la inspeción necesaria, para lo cual presentarán por duplicado una memoria explicativa, plano, pliego de condiciones facultativas y presupuesto, hasta tanto que formalicen la oportuna cuenta justificada, la cual deberá ser censurada ó aprobada dentro de los 60 dias siguientes al de su presentación, prévio anuncio en la Gacela y en

(1) En la Parte 1.' cap. II. 
el Bolelin Oficial de la provincia, con objeto de que cualquier persona pueda axaminarla libremente dentro del plazo de 30 dias y formular las reclamaciones que tanto acerca del coste, como de la solidez de las obras, y cualquier otro pormenor relativo á las mismas estime procedentes. La aprobación de las cuentas corresponderá al Gobernador, prévio imforme del Ingeniero Jefe de obras públicas, y de la Comisión provincial, si el importe de las obras realizadas no pasa de 10.000 pesetas, y si excede de esta suma, al Ministro de Fomento; debiendo oir en todo caso los informes de los Gobernadores, Diputaciones é Ingenieros de las provincias donde se hayan efectuado las obras, Junta consultiva del ramo, y demás informes que estime necesarios. Asi se facilitaba la construcción de obras de utilidad general, se conseguia además la publicidad, y se evitarian muchos inconvenientes y abusos.

También deberán llevarse á efecto por el Estado las obras de utilidad pública más precisas y urgentes, prévio el estudio y formación de los proyectos oportunos, é indemnización por las expropiaciones que realice, por cuyo medio se lograria realizar aquellas sin necesidad de acudir á los capitales extranjeros, y se abririan manantiales de inapreciable riqueza. 
Las vias de comunicación

y los transportes de productos agrícolas.

Uno de los elementos que más poderosamente influyen en el desarrollo de la riqueza agricola, son las vias de comunicación.

El exceso de productos en unos puntos, y la mucha carestia en otros, puede llegar á equilibrarse por aquel medio, pues las vias facilitan los transportes, y ponen en contacto inmediato los productos agricolas con los diferentes centros consumidores, pués sabido es que en los puntos productores inmediatos á los centros de exportación, son generalmerte más elevados los precios de los artículos de consumo que aquellos que se encuentran á mayor distancia, y que cuantas más facilidades haya en las exportaciones, mayores son las ventajas que resultan tanto al productor como al consumidor.

Es, pués, de necesidad apremiante construir caminos de último orden, designando los que han de corresponder á las Diputaciones y á los ayuntamientos; carreteras de segundo y tercer orden y ferrocarriles económicos, ya que los de via ancha pueden atender y llenar cumplidamente en la actualidad las necesidades del tráfico.

A tan importante fin será conveniente que el Gobierno decrete la libre construcción 
de vias secundarias que sirvan de enlace á los ferrocariles principales, minas, fábricas y mercados, para dar vida y desarrollo al tráfico interior, aunque sea utilizando para ello las carreteras y caminos provinciales y locales, hoy que importantes regiones agricolas se hallan necesitadas de ferrocarriles secundarios que las pongan en contacto inmediato con los diferentes centros comerciales; y porque á la mayor facilidad en las comunicaciones habrá de seguir como consecuencia lógica un precio más reducido para la exportación y mejor salida de productos.

Es asimismo necesario excitar el celo de los Ayuntamientos de poblaciones situadas a distancias menores de ro kilómetros de las estaciones de ferrocarriles, para que construyan caminos vecinales que pongan en comunicación directa con las vias principales los productos del suelo y de la industria, pues también es indispensable el arreglo y construcción de los caminos de último orden y de interés exclusivamente local, y porque cuantas más vias de comunicación afluyan á las arterias principales, mayores facilidades de transporte encontrarán los productos agricolas y pecuarios.

$\mathrm{Y}$ por último, es de conveniencia suma para los intereses de la agricultura y ganaderia (así como también los de la industria y del comercio) que todo cuanto queda 
consignado(I)respecto á las tarifas de transporte para los cereales y harinas, sea extensivo y comprenda igualmente á los vinos y á todos los demás productos agricolas y pecuarios, abonos, máquinas agrícolas, etc., como medio de activar el movimiento interior y de acrecentar la producción nacional.

\section{Los Pósitos y los Bancos agrícolas.}

Uno de los mayores obstáculos con que el labrador tiene que luchar constantemente para el cultivo de la tierra, es la falta de capital.

El dinero es indispensable, no sólo para librar al agricultor pobre de la despiadada usura, si que también para que pueda perfeccionar el cultivo de sus fincas, adquirir buenas semillas, abonos, maquinaria, ganados, aperos, pago de contribuciones, y también para cubrir sus más perentorias necesidades en un año de mala cosecha.

Por más que en la inobservancia de la ley $1 .^{2}$ tit. II, cap. III, de la Novísima Recopilación, la de 26 de Junio de 1877 , reglamento para su ejecución de II de Junio de 1878 y demas disposiciones vigentes en la materia, estriba la defectuosa administración de los Pósitos, y consista el que éstos no respondan ya al objeto principal de institución tan

(l) En la Parte segunda cap. II. 
veneranda, conceptuamos más conveniente que el exacto cumplimiento de las mismas, la creación de Bancós agricolas regionales, en harmonia con lo que exigen los adelantos modernos, las costumbres actuales, y aun las necesidades de los labradores.

En I84I publicó el Gobierno ciertas bases para establecer Bancos de socorro ó de labradores en las capitales de provincia y pueblos de alguna importancia con el caudal de los Pósitos y con el producto de suscripciones que debian iniciar los pueblos que lo desearen.

La ley de $1 .^{\circ}$ de Mayo de 1855 autorizó á los Ayuntamientos para utilizar el 80 por 100 de sus capitales de propios en el establecimiento de Bancos agrícolas ó territoriales, y algunas Corporaciones hicieron uso de la facultad que se les concedia, por cuyo medio se crearon Bancos agrícolas en muchos pueblos, prestando buenos servicios á los labradores, hasta que el Gobierno publicó una orden en Io de Agosto de 1874 , dejando sin efecto la autorización indicada.

En 3 de Julio de 1886, el Sr. Montero Rios, entónces Ministro de Fomento, presentó un proyecto deley, precedido de una luminosa exposición, en la que desarrolló el muy interesante y dificil problema de crédito agricola; sin haber logrado que tan importante proyecto llegase á la categoria de ley. 
Por Real decreto de 15 de Octubre de 1889 , se mandó publicar un interrogatorio para conocer el estado de los Pósitos, las deficiencias de su legislación, y el modo más acertado y conveniente de establecer el crédito agrícola sobre la base de los expresados establecimientos; y no obstante haberle contestado curnplidamente los Ingenieros agrónomos y los Secretarios de las Comisiones permanentes del ramo, nada práctico se ha hecho, á pesar del proyecto que la Dirección general de Administración local presentó en 1892 à la Junta de Pósitos para convertir éstos en Bancos agricolas provinciales.

El notable proyecto de ley del Sr. Torre Minguez, de 16 de Mayo de 1894 , presentado al Congreso en la sesión del dia 22 del mismo, á fin de crear Bancos agricolas con las inscripciones ó láminas de los bienes de propios vendidos, los montes que los Municipios quieran vender y los Pósitos liquidados, habria de dar en la práctica resultados tangibles y provechosos para los agricultores; siendo de lamentar, que á pesar de estar dictaminado por la Comisión respectiva, no baya sido puesto à discusión y convertido en ley para que funcionasen ya tan precisos establecimientos benéficos, facilitando auxilios metálicos á los labradores necesitados.

Los Bancos agricolas son hoy indispensables como complemento del crédito 
territorial para que los frutos, ganados y las cosechas del agricultor se pongan en condiciones análogas á las de la propiedad territorial.

No es posible demorar por más tiempo una obra verdaderamente trascendental; un auxiliar tan poderoso para la agricultura; un consuelo oportuno y eficaz para los labradores poco acomodados, ganaderos y colonos.

Para aumentar el capital de los Bancos agricolas, podrian admitirse suscripciones en cuenta corriente de 50 pesetas en adelante, abonando un interés módico á los imponentes, con lo cual se conseguiría además constituir una especie de Caja de Ahorros á imitación de los Bancos agrícolas de Escocia y Baviera.

Siendo, pues, tan necesario el capital para el cultivo de la tierra (I), el Gobierno debe dedicar una atención preferente $\mathrm{y}$ asidua para vencer todos los obstáculos y dificultades con que desde hace algunos años se viene luchando por la realización de un proyecto de tanta importancia como el de los Bancos agricolas.

Todas las naciones que aspiran al fomento de la riqueza agricola, cuentan con el valioso concurso de los Bancos agrícolas. En

(1) Pues como dice Adan Smith: "el capital es quien pone la tierra en estado de cullivo y el trabajo en actividad». 
Francia se han efectuado diferentes ensayos desde 1840 hasta llegar á la ley de 1874 y proyecto de 1892 , habiendo tenido que vencer un sin número de dificultades para conse. guir establecer el crédito agricola mobiliario; el cual es más necesario en España, en que los labradores disponen de menos capital que los de aquella nación poderosa.

Si bien reconocemos que existe cierto retraso en algunos labradores (aunque no en el grado máximo que muchos los atribuyen), también es preciso reconocer que no pueden muchas veces desarrollar sus iniciativas, ni dar impulso á las buenas prácticas de cultivo por la falta de dinero; y de poco ó nada servirán los descubrimiento de la ciencia si los labradores no pueden utilizarles por carecer de recursos, pues todas las operaciones, ensayos y mejoras, requieren capitales, de los que no siempre dispone el agricultor; pocas veces tiene facilidad de adquirirle en condiciones ventajosas, y ya es sabido que una de las causas deque el suelo español no produzca todo lo que debiera y que motiva el estado de nuestra agricultura, es la falta de capital.

Problema económico de nuestros dias, es el de facilitar dinero á un interés módico á los labradores y ganaderos sobre el valor de sus cosechas, aperos y ganados, mediante condiciones fáciles de reintegro y de modo que los préstamos estén basados en el uso 
más que en el abuso de los mismos; pues el agricultor que reciba cantidades más ó ménos considerables sobre los productos de sus fincas, podrá devolverlas más fàcilmente que si lo recibe sobre el capital.

Inteligencia, capital y trabajo, son los tres elementos necesarios para la producción, además de los agentes naturales, y careciendo de dinero la mayor parte de nuestros labradores no pueden, por tal circunstancia, obtener del cultivo de sus fincas los rendimientos de que las mismas son susceptibles, ni promover importantes mejoras en la agricultura.

Por lo tanto, urge establecer bajo sólidas bases en España una institución tan iútil y provechosa como los insinuados Bancos agrícolas, con el objeto de facilitar á los labradores los fondos que necesiten para que las operaciones sean todo lo extensivas é intensivas que requieran las fincas que cultivan, particularmente á los colonos que, por regla general, no tienen fincas que hipotecar á la garantia del dinero que toman á préstamo, y no es justo abandonarlos por más tiempo á sus débiles fuerzas: debiendo regular y limitar la distribución de los préstamos con bases inspiradas en la equidad y en la justicia, para evitar lamentables abusos, y que la influencia ó el caciquismo, favorezca más á los privilegiados que á los necesitados; 
como asi, bien, preferir la garantia personal, fiador de abono, ó la obligación mancomunada, á la prendaria ó hipotecaria, y reducir cuanto sea posible las operaciones concernientes á los préstamos, para la mayor facilidad de los mismos, y no causar otros gastos que los que sean absolutamente precisos; y disponer por último todo cuanto además conduzca á que los indicados establecimientos de crédito llenen cumplidamente el objeto de su institución, por ser uno de los medios más eficaces que pueden conducir á la prosperidad y florecimiento de nuestra empobrecida agricultura, y de elevar à la numerosa clase agraria al grado de bienestar á que tan justos y legitimos titulos es acreedora.

\section{Seguridad y policía rural.}

La poca seguridad que ofrece la vida en los campos, y el poco respeto á las propiedades y frutos, aleja de aquéllos á muchos agricultores que con su inteligencia. y su capital pudieran fecundarlos. No es ya solamente el propietario el que abandona las casas de campo y las poblaciones pequeñas. por la falta de seguridad, sino que la misma tendencia se observa en el obrero.

La población rural es en extremo necesaria, porque los propietarios que viven en el campo á la vista de las fincas que cultivan, 
no tienen precisión de recorrer largas distancias para labrar aquellas, con cuyo motivo pierden un tiempo precioso los que habitan en las poblaciones. Además la vida en el campo es más sana, más económica, y aún de mayor recogimiento en la materia y el espiritu.

Es, pues, necesario dar seguridad á nuestra población rural, á fin de que los propietarios españoles puedan vivir en el campo como los lores ingleses en paz y tranquilidad, dedicándose á la explotación de sus fincas, y para que la vida de los agricultores, sus haciendas é intereses no se encuentren á merced del capricho ó mala voluntad de los discolos, descontentos ó mal intencionados, pues los Alcaldes y Jueces municipales de los pueblos, no pueden corregir los muchos daños y abusos que se cometen en las propiedades, porque carecen del apoyo valioso que presta la fuerza material; único medio eficaz para contener en sus extravios á los que no tienen respeto ni temor á las leyes divinas, ni á las humanas.

Los buenos resultados obtenidos desde que por la ley de 7 de Julio de 1876 se confió á la Guardia civil la custodia de los campos, particularmente de los montes del Estado, requiere que se generalice y complete tan indispensable condición para el mejor desarrollo y explotación de la agricultura y 
ganadería; á tin de evitar que algunos propietarios se retraigan de vivir en su fincas de campo, y que otros tengan que adoptar muchas precauciones para no ser victimas de atropellos y atentados; pues el corazón humano alcanza ya, por desgracia, un grado de perversidad que, los muchos crímenes y desmanes que se cometen, son una lúgubre prueba de lo que pudiera llegar á ser, si el Gobierno, las autoridades locales, la fuerza pública, los Tribunales, y todos los hombres de órden, desde el más opulento hasta el más humilde jornalero, no desplegasen la actitud, energía y firmeza de caracter para reprimir y corregir aquellos.

Como el alejamiento de los campos puede ocasionar el abandono del cultivo, y la decadencia y ruina de la, agricultura, estimamos preciso para el fomento de la población rural:

1. Aumentar la Guardia civil en todas las provincias para que los puestos que en la actualidad existen, estén dotados suficientemente; creando además los necesarios, á fin de que dicho Cuerpo pueda desempeñar por completo el servicio de seguridad y policia rural en todo el Reino.

2. Con el objeto de no gravar el presupuesto del Estado, los gastos que ocasione el aumento de la Guardia civil, será satisfecho por las provincias cuyas Diputaciones 
reclamen el auxilio de dicha fuerza, ó aquellas á que se la destine á prestar servicios, según donde hubiere más notoria urgencia, á juicio del Gobierno, prévio informe de la Dirección general del ramo.

3. Si algún Ayuntamiento deseare crear en su término algún puesto de la Guardia civil, le será concedido siempre que sufrague los gastos que ocasione este servicio, y facilite casa-cuartel para la expresada fuerza; en cuyo caso suprimirà la guardia rural y forestal que tan gravosa es en algunos Municipios. Los Ayuntamientos que no puedan sostener por sí solos el mencionado servicio, podrán asociarse á otros cuyos términos estén limitrofes; debiendo solicitarlo de la Dirección general de la Guardia civil, por conducto del Gobernador de la provincia.

$4 .^{\circ}$ Hasta tanto se organice el repetido servicio, y cuando las circunstancias lo permitan y requieran, se distribuirá parte del Ejército activo por las poblaciones pequeñas, á fin de que preste apoyo á las autoridades locales; y también á los agricultores para que puedan dedicarse con tranquilidad al cultivo de sus propiedades, en particular cuando los frutos se hallen pendientes, y durante su recolección. 
Canales y pantanos.

La utilidad de los riegos es incuestionable para la mejora y fertilización de los campos, pues sabido es que el agua acrecienta extraordinariamente las cosechas, y es el elemento más potente y necesario para la germinación y desarrollo de las plantas, sobre las que obra fisica y quimicamente, $y$ distribuye de una manera uniforme las materias propias á su nutrición.

La desecación y saneamiento de terrenos y la apertura de canales de riego derivados de los rios, arroyos, lagunas y manantiales, donde la naturaleza y accidentes del terreno lo permitan, es una de las reformas altamente beneficiosas para la salubridad pública, y muy importante para el desarrollo de la agricultura y mejora de la ganaderia, porque el riego aumenta los productos de la tierra y contribuye á remediar las desigualdades atmosféricas. Las sequias tan prolongadas y funestas que en diversos años han esterilizado los campos, debieran servir de provechosa lección tanto al Gobierno como á los agricultores y al país en general, para tratar de remediar una de las mayores calamidades que con frecuencia sufren los labradores, y que puede evitar en gran parte la mano del hombre, particularmente en España, pais 
montañoso y accidentado, con ríos caudalosos, innumerables arroyos, pendientes naturales y condiciones de todo género para facilitar el riego á los campos, sin casi el auxilio de la Mecánica.

Las subvenciones propuestas para los que construyan obras de utilidad general, deberán comprender también las relativas á los canales y pantanos. Unos y otros pueden recoger y conservar las aguas perdidas durante la mayor parte del año, para utilizarlas con la debida oportunidad en el riego de las grandes zonas que pueden ser convertidas en veneros de in a preciable riqueza; debiendo publicar el Gobierno los datos hidrológicos y cuantos antecedentes sean necesarios á facilitar la iniciativa privada, y conceder la preferencia para lo relativo á los premiosó subvenciones, antes que á las grandes empresas, á los Ayuntamientos, propietarios, sindicatos y comunidades de regantes, y mejor aún que el Estado acometa por su cuenta los trabajos de canalización, utilizando al efecto los sobrantes del Ministerio de Fomento, ó consignar en presupuestos las cantidades que á tan importante fin se estimen necesarias, imitando la conducta del Gobierno de Francia, que ha sacrificado considerables sumas para la construcción del canal del Rodano. En nuestro país existen diferentes rios que corren sin utilidad alguna para la 
agricultura, y extensos terrenos casi estériles, de los que por medio del agua podrian obtenerse crecidos rendimientos, pues de $50 \mathrm{mi}$ llones de hectáreas dedicadas al cultivo, no se riegan ni siquiera dos millones de hectáreas: debiendo por último regularizar los riegos existentes, y considerar de importancia suma todo lo referente al sistema de riegos y desecaciones, puesto que la falta de lluvias y la disminución de aguas corrientes y de manantiales originan muchos años la escasez y pérdida de las cosechas, y como consecuencia natural é inmediata el hambre y la miseria.

\section{De las minas.}

La producción minera es otra de las riquezas que también experimenta una grave crisis; siendo indispensable buscar medios eficaces para el verdadero desarrollo de esta importantisima ind ustria, unode los mayores reneros de nuestra riqueza nacional, cuya explotación practicaron en otros siglos y en tan grande escala, por las excelentes condiciones de nuestro suelo, los cartagineses y los romanos.

Felipe II dedicó atención suma á tan importante ramo de riqueza pública, procurando remover los obstáculos que se oponían á su desarrollo y prosperidad, á cuyo efecto en 
22 de Agosto de 1584 publicó las ordenanzas que forman la ley $4{ }^{3}$ tit. XVIII, lib. IX de la Novisima Recopilación, y han constituido un sistema completo de legislación en la materia por el que se ha regido el ramo de minas muy cerca de 300 años.

La extensión súperficial de los terrenos. carboniferos excede en España de $11.000 \mathrm{ki}$ lómetros cuadrados, con más de $15.000 \mathrm{mi}$ nas, de las cuales unas 2.000 son productivas de hulla, cobre, hierro, acero, plomos y otros minerales, y en los que se hallan ocupados constantemente muchos millares de obreros.

La riqueza minera es una de las más interesantes de nuestra industria nacional y España es la nación mas productora en hierro, cuyo gran elemento ha llegado á constituir un artículo de primera necesidad en la sociedad moderna.

Es pues necesario que el Gobierno conceda la debida protección á las empresas mineras, para que puedan explotar los inmensos. veneros de riqueza que el suelo español atesora, y que en atención al estado de pobreza en que se encuentran algunas comarcas montañesas, proteja fecundas y salvadoras. iniciativas particulares, no para que obtenga pingües beneficios ó halagüeños resultados, ni tampoco privilegios de que antes disfrutaban los mineros ó explotadores de minas, 
sino para que no sufran pérdidas los que aventuran considerables capitales para el fomento y desarrollo de una de las principales riquezas del pais.

A tal fin conceptuamos necesario:

1. Suprimir en absoluto los derechos de exportación á las galenas y à los plomos y litargirios argentiferos, para que en lo sucesivo puedan ser exportados con entera libertad de derechos, no solo durante el ejercicio de I895-96, como preceptúa el art. 47. de la ley de Presupuestos de 30 de Junio de 1895 , sinó por todo el tiempo que dure la actual crisis minera.

2. ${ }^{\circ}$ Que el Gobierno solicite de las naciones donde se importan minerales, la supresión ó rebaja de los derechos de importación que hoy adeudan aquellos.

$30^{\circ}$ Suprimir ó reducir, cuando las necesidades del Tesoro lo consientan, el impuesto equivalente al 30 por 100 del canon de superficie, y el del 2 por roo sobre el producto bruto de la riqueza minera.

$44^{\circ}$ Derogar la ley de forrocarriles en la parte relativa à la franquicia arancelaria á los materiales que se importan para la construcción y servicio de los mismos, cuyo privilegio en favor de las Compañias ferroviarias coloca á la industria de hierro en condiciones tan desventajosas que hace imposible su competencia con la del extranjero. 
$5 .^{\circ}$ Facilitar medios de transporte para los minerales ya que éstos, particularmente los carboniferos, luchan en la actualidad con obstáculos casi insuperables para el arrastre de los mismos.

6. Conceder facultades á las Empresas mineras para construir vias secundarias que enlacen con las generales, á fin de que puedan conseguir más pronta salida y más ventajósa colocación á sus productos; pues el ser tan reducidos los precios de los mismos, 5 tan lentos y costosos los arrastres, constituyen el escollo principal de su explotación.

$7 .^{\circ}$ Crear escuelas de Capataces del ramo, como las de Almadén, Cartagena, Linares etcétera, en las zonas ó cuencas carboniferas de las provincias de Oviedo, Santander y Alava que más lo necesitan para difundir los conocimientos y formar funcionarios prácticos que auxilien á los Ingenieros de minas, con el objeto de que la industria minera pueda ser ejercida con la debida utilidad y provecho.

8. Simplificar la tramitación referente al establecimiento y explotación de industrias mineras á fin de conceder toda clase de facilidades á cuantos exponen sus intereses en beneficio de la producción nacional, proporcionan trabajo á multitud de jornaleros y originan por tal medio, aumento en el consumo de los productos agrícolas y pecuarios. 
Legislación hipotecaria y de derechos reales.

El antiguo y conocido impuesto de Derechos reales y transmisión de bienes, denominado también de hipoteca, establecido como garantía para las familias, à fin de asegurar la propiedad, evitar intrusiones, contiendas y demandas, y llegar á conocer la riqueza inmueble, su extensión y valor, ha tomado despues un caracter exclusivamente fiscal (pues la moderna legislación hipotecaria realiza ya la insinuada especie de investigación), y desde la época de la monarquia goda, cuyas alcabalas fueron origen del expresado impuesto, hasta 1892 han sido muchas las reformas que se han dictado para determinar los actos sujetos al impuesto, unificar las tarifas, comprender nuevos actos en el gravamen y aumentar considerablemente el mismo; objeto principal de las últimas reformas.

El referido impuesto que hace 50 años solo comprendía á un corto número de contribuyentes, afecta en la actualidad á casi todos las españoles, desde el más opulento al menos acomodado, puesto que la Hacienda cobra sus derechos hasta en las herencias y legados en sufragio del alma de terceras personas y del mismo testador, en los legados á 
metálico destinados á la reparación de las iglesias de los pueblos que se arruinan porque el Gobierno no se cuida de sostenerlas, y en las transmisiones destinadas á la creación de instituciones de enseñanza gratuita, aunque sean de carácter privado y para aliviar la triste situación de los niños pobres de las aldeas.

Desde la reforma de 1892 es muy raro el español de cualquier sexo, estado y condición que puede dar un paso en materia de contratos, de herencias, permutas, ventas, transmisiones y legados sin que tropiece con el mencionado impuesto; lo cual dificulta las transmisiones, en perjuicio de los interesados y aun de la misma Hacienda, pues de todos es sabi. do que hay muchas testamentarias y contratos asi corrientes como atrasados sin formalizar, y numerosas fincas de escaso valor que no se transmiten por no tener sus dueños titulos de ninguna clase; y como para adquirirlos conforme à la legislación vigente sea necesario practicar operaciones costosas $y$ vejatorias, con el objeto de obviar dificultades y economizar gastos es conveniente y hasta necesario modificar la ley hipotecaria, reglamento para su ejecución y el de Derechos reales, en el sentido de establecer derechos módicos y dar facilidades para las transmisiones de fincas y la inscripción del dominio ó de la posesión en el Registro 
de la propiedad, particularmente cuando el valor de aquellas no exceda de mil pesetas; con lo cual ganaría tambien el Tesoro público, y por cuyo mediose podrá conseguir que algunas fincas que en la actualidad no se labran pasen á otros dueños que las cultiven con esmero y tambien de que por compras y permutas vayan desapareciendo paulatinamente las pequeñas parcelas que tantos inconvenientes ofrecen para la mejora de cultivos y poder formar, en un periodo de tiempo dado, propiedades de mayor extensión, ya que no sea conveniente obligar á los pequeños propietarios á que cedan sus fincas de usa manera violenta.

El impuesto de consumos.

La contribución conocida en la actualidad con el nombre de Impuesto de consumos que $\tan$ buenos rendimientos proporciona al Tesoro público, es tan antigua que casi se pierde en la oscuridad de los tiempos, y desde hace ya siglos se conoció en España, aunque con diversos nombres $y$ denominaciones.

El referido impuesto viene considerado, y á no dudarlo que lo es, el más repulsivo y odioso de todos cuantos hoy conocemos, y por más que no es exclusivo de nuestro pais, subsiste solamente por la ley de la necesidad. Como elemento tributario, preciso es 
reconocer que es indispensable mientras el Presupuesto de gastos no pueda reducirse, ó se estudian los medios y la forma de sustituirle por otro ú otros menos gravosos y molestos, y más adaptables á los tiempos actuales.

Todos los tributos, tanto directos como indirectos requieren la más recta equitativa y proporcionada distribución, pero con mayor razón aún el de consumos, por lo mucho que grava algunas especies de las comprendidas en las Tarifas, en particular las de primera necesidad, con lo cual se perjudica considerablemente á la clase media é inferior. Por otra parte, las disposiciones vigentes en la materia dejan mucho que desear, por lo cual conviene modificarlas conforme á lo que aconseja la experiencia; siendo muy necesarias, entre otras reformas las siguientes:

I." Distribuir los cupos á las poblaciones. en proporción á su vecindario consumidor y á los elementos de riqueza que aumenten ó disminuyan el consumo, en vez de sostener el cálculo del consumo individual, sin diferenciar el relativo á los habitantes del extrarradio, de los del casco y rádio, y sin tener en cuenta si aquellas son capitales de provincia, puertos de mar, cabezas de partido, estaciones de ferrocarriles, si tienen establecimientos balnearios, ferias, mercados, 
cuarteles con guarnición, distancias á los centros consumidores, etc., etc.

2." Modificar la Tarifa de las especies sujetas al impuesto con la tendencia á rebajar y, á ser posible, suprimir los derechos establecidos sobre los artículos de alimentación de primera é indispensable necesidad, gravando en su equivalencia los que no reunan esta circunstancia.

3." Derogar el art. 9. de la ley de 7 de Julio de i 888 para que los Ayuntamientos y contribuyentes asociados puedan disminuir el gravámen á las especies comprendidas en las Tarifas, y aun de excluir de éstas los artículos que las expresadas Corporaciones estimen conveniente á los intereses generales y circunstancias de localidad, y á lo que permita la situación financiera de cada respectivo Municipio; á fin de aliviar por tal medio á las clases productoras.

4." Ampliar hasta 20 las 12 categorias establecidas por la supradicha ley, en razón á ser muy limitada la escala gradual de cupos en clases y categorias.

5." Para fijar el cupo á cada población se deducirá del número de sus habitantes los exceptuados del impuesto por la ley de colonización agrícola de 3 de Junio de 1868 .

6. También deberá deducirse el 50 por Ioo correspondiente á los habitantes del extrarradio, ó derogar la regla 8. ${ }^{a}$ del art. Io 
de la ya citada ley y el cap. 20 del reglamento de 2 I de Junio de 1889 , con lo cual, además de evitar pendencias y abusos, ganarían los principios fundamentales de justicia y de equidad administrativa.

7. : Suprimir la separación de los alcoholes, aguardientes y licores.

8." Disponer que para los líquidos y cereales no haya encabezamientos gremiales obligatorios y puedan, por consiguiente, ser objeto del oportuno repartimiento como las demás especies tarifadas.

9." Determinar otras bases y reglas más ámplias y equitativas para la ejecución de los repartimientos vecinales, encaminadas á evitar notorias desigualdades en perjuicio de los contribuyentes.

Io. Conceder facultades à las indicadas Corporaciones municipales, en particular las que se hallen al corriente en sus pagos con la Hacienda, para que adopten libremente los medios que juzguen más conducentes para cubrir sus respectivos cupos de consumos, en armonia con lo que aconsejen y requieran las costumbres y condiciones de cada localidad; favoreciendo al propio tiempo los intereses de la agricultura. 
Exposiciones nacionales, regionales

y consulares.

Las exposiciones ó grandes certámenes, ya emanen de la iniciativa oficial ó privada, contribuyen poderosamente á estimular el progreso en los diferentes ramos del trabajo, lo mismo agrícolas que industriales, artísticos y literatos; y son uno de los medios más eficaces de que se valen los pueblos civilizados para fomentar la unión de los mismos y dar gallarda muestra de cultura, ingénio y laboriosidad, evidenciar las mejoras ý adelantos modernus, y dar á conocer los articulos y productos de los fabricantes y cosecheros.

Cierto que no se expenden los géneros tan bien acondicionados como los exhibidos en las exposiciones, porque con ellos suele suceder una cosa idéntica á los vinos que expontáneamente son presentados para su análisis en los laboratorios, que entónces aparecen puros y sanos, pero que, en muchos casos, no sucede lo mismo cuando después se destinan á la venta. Sin embargo, como quiera que en la celebración de tales certamenes siempre se obtienen adelantos de más ó menos importancia, será altamente plausible y provechoso todo cuanto tienda á favorecer nuestra riqueza pública, y à tal fin convendrá: 
I. ${ }^{\circ}$ Celebrar exposiciones nacionales, y estimular á las Diputaciones de provincia para que sin perjuicio y con entera independencia de aquellas, celebren à su vez las regionales que estimen necesarias, á fin de premiar á los agricultores y ganaderos que presenten mejores productos.

2..$^{\circ}$ Sin perjuicio de las exposiciones mencionadas, será también conveniente establecer otras de productos agricolas y pecuarios (y aun industriales) en los consulados de España, para dar á conocer aquellos en el extranjero, de idénticá manera á la propuesta para los vinos (I); debiendo designarse un personal idóneo para el desempeño de tan importante servicio, y una de sus principales obligaciones será la de formar todos los meses y remitir para su publicación, al Ministerio de Fomento, una memoria detallada de los articulos ó productos que por su mediación hayan obtenido venta; precios de los mismos; aspiraciones de los mercados; condiciones que han de reunir las mercancias para su más ventajosa colocación; derechos que hayan de satisfacer; y todo lo demás que estime conducente para la mejor salida $y$ venta de los productos nacionales.

(1) En la Parte 2.', cap. I. 


\section{Animales útiles y dañinos á la agricultura.}

Además de los perjudiciales á la ganaderia, de que ya nos hemos ocupado al final de la parte segunda, conviene determinar con toda precisión y claridad los que sean útiles y perjudiciales á la agricultura, y establecer pequeñas multas para los matadores de los primeros, y premios para los de los últimos.

El gobierno de los Estados-Unidos dedica todos los años crecidas cantidades á investigaciones entomológicas útiles á la agricultura.

aEs sabido que los mayores enemigos de la agricultura son los insectos; las pérdidas que ocasionan no pueden compararse con las heladas tardias, lluvias inoportunas, temporales, piedra, granizo, sequia, etc., pues todas estas reunidas no alcanzan en mucho a las ocasionadas por dichos animales (I)".

Según el Sr. Maceira los pájaros y otros animales, la culebra, el lagarto, el murciélago, el erizo, el topo, etc., en el concierto harmónico de la naturaleza, y con esfuerzos infinitamente pequeños, evitan fenómenos, muchas veces, de una magnitud imponente.

(1) Rev. del Instituto agrícola de San Isidro. 
P. Joizgneaux, en su obra del mismo eptgrafe que el presente, sienta como principio que los animales insectivos y, con ciertos limites, los carnivoros, son útiles á la agricultura; y que los granivoros, frugivaros y herbivoros le son perjudiciales.

\section{Animales útiles.}

Al definir los mamiferos, las aves rapaces, los pájaros, los reptiles y los invertebrados, recomienda en primer término á la protección de los agricultores, los murciélagos y animales insectivoros, que son injustamente perseguidos y exterminados, sin sospechar que nos rinden grandes servicios, cual golondrinas de la noche, purgando la atmósfera de infinitos insectos que nos atormentarian durante la noche.

Después recomienda la musaraña que limpia las huertas y jardines de insectos, larvas, limazas, tigeretas; el erizo, que también se alimenta casi exclusivamente de insectos; los vencejos, golondrinas, pollalbas, ruiseñores, currucas, silvias, alondras, cogujadas, calandrias, estorminos, gorriones (I),

(1) Contra los que abrigan tanta prevención los labradores, porque comen algunos granos de trigo, y el mal que con esto ocasionan, no equivale, según Joigneaux, á una milésima que nos callsarían los insectos, conque se alimentan. El naturalista Tschudi 
tordos, mirlos, perdices, codornices, cigüeñas, lagartos, culebras, los sapos (I) y el buitre, que contribuye á la higiene pública.

\section{Animales dañinos.}

Entre los animales dañinos, enumera los alacranes, arañas, escorpiones, escolopendras, abejorros, mariposas de noche, mosquitos, saltones; las àguilas, alconesazores, gavilanes, el lobo, el oso, el lince, la zorra, el tejón, la garduña, el armiño, la comadreja, la nutria, la rata, la ardilla y la víbora, cuya persecución y exterminio debe el Gobierno recomendar eficazmente, sin perjuicio de disponer se remunere á los matadores de lobos, osos, garduñas y demás animales dañinos que determina el reglamento.

La protección á los animales útiles y necesarios en los campos, corresponde á los

asegura que una pareja de gorriones consume por semana en la alimentación de sus hijuelos tres mil insectos y muchas langostas, gusanos y hormigas.

(1) Reputados por muchos labradores de venenosos, sin serlo; no muerden por carecer de dientes y se alimentam de todos los insectos, gusanos y babosas que encuentran. En Inglaterra y Bélgica los hortelanos y jardineros los compran en los mercados á buenos precios, persuadidos de su utilidad, y á los que consideran como centinelas de frutos y legumbres. 
Ayuntamientos y particulares. Además el Gobierno debe recomendarla eficazmente y disponer á imitación del de Francia, que los profesores de instrucción primaria inculquen á los niños la necesidad de proteger à los animales útiles, llamando la atención de los alumnos sobre los beneficios que producen á la agricultura destruyendo un considerable número de insectos y otros animales perjudiciales, enseñándoles además á distinguir lo bueno de lo malo, lo útil de lo nocivo. También deberá establecer algunas multas contra los matadores de los murciélagos, cigüeñas, sapos y demás animales útiles que se especifiquen en el oportuno reglamento para conocimiento del público; de la propia manera que detallar los premios con que se habrá de recompensar á los que maten los animales dañinos.

\section{De los Veterinarios.}

El veterinario es el consejero inmediato del labrador y del ganadero, el que por sus estudios y conocimientos puede mejorar las razas de los ganados, conocer mejor las enfermedades que éstos sufren, el modo de precaverlas y combatirlas, y contribuir a la prosperidad y desarrollo de la industria ganadera. 
Por tanto, será conveniente:

I. Q Que el Estado disponga lo necesario para ampliar los estudios técnicos, haciendo obligatorio el grado de bachiller como base preliminar para los estudios de una ciencia importante à la riqueza pública, á fin de lograr, que el veterinario sea tan médico como zootécnico; elevando así su clase à la altura que demandan los intereses sanitarios, y por ser además uno de los medios indispensables al fomento de la ganadería.

2. Siendo tan insignificantes las cantidades consignadas en los presupuestos municipales para inspección de carnes, que en algunos no excede de 10 pesetas al año, procede que el Gobierno excite el celo de los Ayuntamientos para que consignen en sus presupuestos la cantidad de So pesetas como minimum, á fin de que tan importante servicio público tenga una retribución decorosa.

3. Que se modifique la Tarifa circulada con la Real orden de 30 de Marzo de 1875 para el percibo de los honorarios que pueden exigir los veterinarios en el ejercicio de su profesión por reconocimientos judiciales ó particulares, visitas y operaciones que practiquen, elevándolos gradualmente conforme requieren las necesidades de la época presente. 
Indicación de otros varios.

I.

Crear estaciones enológicas en todas las capitales de provincias vitícolas, á fín de generalizar los conocimientos teórico-prácticos necesarios para perfeccionar los tipos de vino con las cualiclades más aceptables para su exportación y consumo; y en las cuales los cosecheros que lo deseen puedan recibir las instrucciones convenientes para obtener las clases mencionadas.

Además, y siendo la instrucción la base del progreso y bienestar de los pueblos, sin perjuicio de las estaciones enológicas insinuadas, se dispondrá también la creación de Escuelas de agricultura teórico-práctica en todas las comarcas ó regiones agricolas más importantes de España, con el objeto de difundir las buenas prácticas de cultivo y obtener de la tierra los mayores rendimientos posibles, para lo cual los agricultores tendrán derecho de asistir con entera libertad á ellas cuando lo tengan por conveniente á fin de que que puedan enterarse con la mayor minuciosidad de los ensayos y labores que en los campos experimentales de aquellas se practiquen. Para evitar viajes, gastos y molestias á los agricultores se dispondrá asímismo que los peritos ó capataces de las 
referidas Escuelas recorran los pueblos de su respectiva demarcación, dando conferencias claras y sencillas sobre agricultura, y enseñando además prácticamente á los labradores la manera de preparar los terrenos, abonos y semillas, de manejar los instrumentos aplicables á cada clase de cultivo, y todo cuanto conduzca á propagar las buenas prácticas, desterrar errores y rutinas y formar hábiles agricultores; debiendo los Jefes ó Direstores de los indicados Centros de enseñanza publicar todos los años una Memoria detallada de todas las operaciones practicadas por el personal de aquellos, tanto en las mismas Escuelas como en los pueblos, resultados obtenidos, mejoras que convenga establecer, y cuantos datos y observaciones estimen conducentes para impulsar á nuestra espirante agricultura por el camino de su regeneración y florecimiento.

\section{II.}

Exceptuar del pago de la contribución industrial á los cosecheros de vino por las ventas que de sus productos verifiquen en almacén ó establecimiento permanente fuera del punto de producción; quedando obligado cada cosechero á acreditar en todo caso, que tales productos no son comprados I si obtenidos de su propia cosecha. 


\section{III.}

Convertir en cuotas reducibles las patentes para la fabricación de alcohol vínico, que deberán prorratearse por lo relativo al tiempo que se ejerza la industria, y causar efecto las bajas que se presenten para el trimestre inmediato; con lo cual en vez de disminuir, aumentarán seguramente los ingresos del Tesoro, y se favorecerá á los industriales que no cuentan con elementos para trabajar todo el año.

\section{IV.}

Elevar los derechos arancelarios à los alcoholes extranjeros que se importen en España, a fin de que los vinos torcidos y los que siendo aceptables no se expendan por falta de compradores, puedan ser quemados más facilmente; y como medio de favorecer las destilerias agrícolas nacionales.

\section{V.}

Eximir del impuesto de patente por destilación de alcoholes ó aguardientes, à los cosecheros de vino que no puedan expender éste por falta de compradores.

\section{VI.}

A fin de que en España no se carezca de los trigos duros y semiduros que para las 
mezclas solicitan con empeño muchos fabricantes del litoral, las Diputaciones provinciales cuidarán de proveer á los Ayuntamientos que de sus respectivas provincias lo soliciten para distribuir entre los labradores, de simientes de trigos exóticos de mayor producción que los indigenas, y de los tipos que los mismos fabricantes prefieren para las harinas llamadas de fuerza; y con objeto de implantar en nuestro pais las variedades de los cereales que requieran las necesidades y aun exigencias de los mercados.

\section{VII.}

Siendo harmonizable el cultivo del tabaco con el actual sistema de monopolio y arriendo, se permitirá en la Peninsula el libre cultivo de las plantas del tabaco en sus distintas variedades, sin perjuicio de los derechos del Tesoro y los adquiridos por la Compañia arrendataria; ya que los ensayos hechos en diferentes provincias han dado excelentes resultados, y á que conforme á la base 12." de la ley de 22 de Abril de 1887 sobre arrendamientos del monopolio de esta planta, puede concederse autorización para el cultivo de la misma con destine á la exportación al extranjero ó á la fabricación oficial, por cuyo medio, y mejor aun por el de su libre cultivo, fijando tipos de contribución á la hectárea cultivada, según su clase, de 
manera que se garantice la renta que hoy percibe el Tesoro, los millones de pesetas que salen de España todos los años para el pago del tabaco en los Estados-Unidos por no ser suficiente el adquirido en neestras posesiones. de Ultramar para el consumo de dicho artículo, prodrian quedar en la Peninsula en beneficio de los agricultores, y asi estos sufragarian mejor los cuantiosos tributos que se los exigen.

\section{VIII.}

El art. 40 de la ley de 30 de Junio de I895, declara en vigor durante el presupuesto de 1895-96 el 42 de la ley de 5 de Agosto de 1893 sobre legitimaciones de posesion mediante un canon á quienes por sí propios ó por sus ascendientes, descendientes, cónyuges ó colaterales hasta el tercer grado hubiesen reducido á cultivo y cultivado normalmente por espacio de ro años, á lo menos, terrenos desamortizables no exceptuados de la venta; lo cual constituye una nueva prórroga en favor de los poseedores de tales bienes ó de las personas con quienes les uniesen el expresado parentesco; pero ésta es algo reducida, y las trabas y dificultades para cumplir tantos requisitos como se exigen, son muchas y muy costosas que obligan à renunciar á los llama. dos beneficios. Es necesario conceder un plazo más ámplio, y muy particularmente dar 
a los interesados toda clase de facilidades, evitándoles gastos y molestias para que puedan acogerse à los beneficios concedidos; pues de no hacerlo así resultará ilusorio cuanto se disponga sobre el particular, como lo prueba el haberse instruido muy pocos expedientes desde 1893 à pesar de ser muchos los poseedores de los terrenos indicados que desean legitimarlos. También es necesario que desaparezca la desigualdad establecida para los cultivadores de los terrenos cuya cabida exceda de io hectáreas; reducir el pago del 60 por ioo de su valor actual en venta á otro más módico, ó al que tenían los terrenos antes de ser roturados, ya que éstos en su mayor parte antes eriales, har sido reducidos á cultivo y algunos á plantaciones de viñedo y olivares á costa de muchos gastos y de improbos trabajos, y no es justo que si el Estado consintió la detentación exija otra cocosa que el reintegro del valor primitivo de aquellos: que el retraso en el pago de algun plazo no determine la pérdida de los anteriores, ni el desahucio de las fincas; que para la legitimación no se exija el pago de contribuciones, porque la mayor parte de los terrenos están sin amillarar, no por voluntad de los poseedores, sino por las dificultades con que han tropezado para ser incluidos en los apéndices y repartimientos de la contribusión territorial; y por último, que conviene tener 
presente que cuantas más facilidades se concedan para las legitimaciones insinuadas, más se han de favorecer los intereses de los pueblos y fomentar la riqueza agricola.

\section{IX.}

En las cartillas evaluatorias deberán admitirse como verdaderos gastos de cultivo los que necesariamente se ocasionan para combatir las plagas del campo, asi como tambien el alquiler decasa, paneras, cuadras, pajares, lagar, envases, etc.; y de los productos líquidos correspondientes á la riqueza rústica y pecuaria, se rebajará el 25 por 100 por eventualidad de cosechas, pérdida y mortandad de ganados, de la propia manera que á la urbana por razón de huecos y reparos.

$\mathrm{X}$.

Crear Estaciones pecuarias, con Paradas de sementales que podrán utilizar los particulares para fomentar sus ganaderias, y en las que se dén las nociones debidas para mejorar y perfeccionar los procedimientos zootécnicos.

\section{$\mathrm{XI}$.}

Llevar á las Córtes un proyecto de ley de policia sanitaria de los ganados, en el que se dicten las medidas más eficaces para preservar, y combatir en su caso, las enfermedades 
contagiosas en los animales, y se establezca además la penalidad en que habrán de incurrir los infractores á la mentada ley de policia sanitaria.

\section{XII.}

Exigir á los Ayuntamientos à quienes comprende la Real orden de I4 de Octubre de I 882 , el puntual y exacto cumplimiento de la misma, á fin de establecer y efectuar en las dehesas concejiles los mercados de carnes en vivo, y registrar todos los contratos que se verifiquen sobre compraventas y permutas de ganados.

\section{XIII.}

Prevenir que los Ayuntamientos de poblaciones mayores de 10.000 habitantes formen un reglamento para el régimen de los $\mathrm{Ma-}$ taderos, con las reformas que en cada región estimen conducentes al fomento de la ganaderia; el cual deberá ser aprobado por el Ministerio de la Gobernación, prévios los informes de la Asociación general de Ganaderos, y Dirección general de Beneficencia y Sanidad.

\section{XIV.}

Elevar los derechos arancelarios para las importaciones de carnes en vivo y muerto, asi como tambien para las lanas súcias, 
limpias é hiladas; por ser uno de los medios conducentes a la repoblación de la ganaderia y de sustraernos à la depresiva servidumbre extranjera, particularmente de la americana.

\section{XV.}

Además de la unificación y rebaja de las tarifas de ferrocarriles para la ganadería lo mismo que para los productos agrícolas, es necesario que los transportes desde los puntos de producción á los de consumo, se verifiquen con la mayor rapidez posible, y con el esmero, precauciones y cuidados que los ganados exigen.

\section{XVI.}

Disponer la constitución de un fondo nacional para remediar las desastrosas invasiones de la langosta y demás plagas del campo; contribuyendo todas las provincias y pueblos por hectáreas, ó con atemperancia á su riqueza agricola; de la propia manera que los propietarios de viñedos pagan una peseta por hectárea infestada de la filoxera, y 50 céntimos por hectárea libre, conforme á lo preceptuado por la ley de 18 de Junio de 1885 .

\section{XVII.}

Exceptuar temporalmente del aumento de tributos á los propietarios que en el cultivo 
de sus fincas y en la explotación de las mismas $\dot{u}$ de la ganaderia introduzcan reformas de verdadera eficacia, ó cualquier mejora positi. va para el fomento de la riqueza agricola y pecuaria.

\section{XVIII.}

Proceder con la mayor actividad á revisar todas y cada una de las concesiones de colonias agricolas, según dispone el art. I I de la ley de 18 de Junio de 1885 ; pues nadie duda que á la sombra de la ley de 3 del propio més de 1868 se cometieron muchos abusos, en particular hasta el expresado año 1885 en que los Gobernadores civiles estaban facultados para concederlas; sin haberse logrado los resultados prácticos que eran de esperar, pues con muy raras y honrosas excepciones los que han obtenido tal privilegio, no se cuidan de introducir mejoras en el cultivo de sus fincas, ni de otra cosa que de eximirse de tributos, en perjuicio evidente de los intereses del Estado y de los pueblos.

\section{XIX.}

Comprender entre lits excepciones que para los embargos enumera el art. 20 de la instrucción de procedimientos contra deudores à la Hacienda pública, las fincas rústicas, las cuales no deberán ser embargadas por débitos de contribución Territorial, y sí solamentelos frutos ó productos de las mismas, 
puesto que aquellas son indispensables pará la vida del agricultor; con lo cual se evitará que muchas fincas queden sin cultivo, y que se convierta à sus dueños en emigrantes ó pordioseros.

\section{XX.}

Proteger á las Compañias de seguros contra el hielo, el granizo y demás calamidades que con tanta frecuencia afligen al agricultor, asi como tambien contra los siniestros, pérdidas y la mortandad epidémica de los ganados; á fin de que resulte mayor beneficio para los asegurados.

\section{XXI.}

Conceder esención temporal de todo impuesto á los que construyan ferrocarriles secundarios, tanto por la adquisición de inmuebles con destino á su construcción, como por los beneficios que se repartan à sus accionistas ó empresarios; pues aquellos son de necesidad absoluta "para la mayor facilidad en los transportes, y pueden servir de auxiliar poderoso á los de vía ancha para los fuertes tráficos y los trayectos largos.

\section{XXII.}

Además de las exposiciones de que anteriormente nos hemos ocupado, se celebrarán concursos bienales para adjudicar premios de honor. 
I.: Al propietario de cada una de las cinco regiones que determina la Real órden de 9 de Febrero de 1882 que cultive mejor una finca de secano; otra de regadio; construya más edificios à mayor distancia de poblado y en mayores condiciones económicas é higiénicas; posea mayor cantidad de plantas exóticas aclimatadas á nuestro pais y de reconocida utilidad; ó convierta mayor extensión superficial en terreno de regadio.

Los premios indicados serán de 5.000 pesetas cada uno, como asi se dispuso por la citada Soberana disposición.

2. A los ganaderos que mejoren notablemente sus razas, ya sea por selección, ó por prudentes y bien entendidos cruzamientos; como medio de obtener la mayor perfección posible y los más ventajosos resultados.

$3 .^{\circ}$ A los autores ó inventores de los aparatos y procedimientos más eficaces para combatir las plagas del campo que devastan las cosechas y causan la ruina de la agricultura.

$4 .^{\circ}$ A los de mejores instrumentos ó máquinas para la práctica de labores agricolas.

5. - A los obreros que más se distingan en las operaciones manuales de cultivo, y en su amor al trabajo, instrucción y virtud; cuyos premios serán por lo menos seis en cada provincia, uno de 500 pesetas, dos de $300 \mathrm{y}$ tres de 200 pesetas, sin perjuicio de los que 
además quieran señalar las Corporaciones provinciales ó municipales, las Sociedades agrícolas y las particulares; debiendo ser abonado por el Ministerio de Fomento el importe de aquellos, conforme dispuso el artículo $80^{\circ}$ del Real decreto de 9 de Diciembre de $188 \%$.

Y 6. ${ }^{\circ}$ Siendo la cuenta y razón indispensable para la economia agricola ó administración rural, y no menos útil para una verda. dera estadística (de las que no suelen cuidarse mucho algunos labradores) en los concursos mencionados, se premiará también á un agricultor por cada provincia de los que con referencia á los litros que deben llevar presente la cuenta más clara, detallada y justificada de los gastos ocasionados en el cultivo de sus fincas, $y$ de los beneficios obtenidos en las mismas; como asimismo al ganadero que acredite iguales extremos respecto à la riqueza pecuaria.

\section{XXIII.}

La dirisión exagerada de las fincas rústicas por la costumbre generalmente seguida en las herencias de repartir todas y cada una de aquellas, por muy reducidas que sean, entre todos los herederos, constituye una rémora constante para el progreso de la agricultura; por lo que es conveniente establecer una unidad agraria que coarte el abuso en las particiones. También lo es facilitar 
la permuta de fincas por razón de utilidad mútua, y relevar del impuesto de Derechos reales á los propietarios que adquieran parcelas inmediatas á las suyas, à fin de que paulatinamente puedan ser reunidos predios dispersos, ensanchando los limites del cultivador, forman cotos redondos, y mejor cultivadas muchas fincas de las que en la actualidad permanecen casi improductivas.

\section{XXIV.}

Favorecer la explotación de la riqueza olivarera y sericícola, como igualmente la de las demás plantas y semillas qué puedan aclimatarse en nuestro país, dar rendimientos al Tesoro público y colocación á la clase obrera, á la vez que producir aumento en el consumo del pan.

\section{$\mathrm{XXV}$.}

Crear y sostener en todas las capitales de provincia, por las Diputaciones respectivas, un asilo para los agricultores indigentes é impedidos, y para los hijos huérfanos de los mismos que quedasen sin medios de subsistencia; como tambien para los obreros ancianos, y los que resulten impedidos para el trabajo por accidentes ocurridos en el ejercicio del mismo, siempre que por parte de cada interesado no se omita cuidado ó prevención alguna para evitarlo. 


\section{XXVI.}

Recomendar á los propietarios y colonos que los arrendamientos de fincas rústicas sean largos y los pagos en especies mejor que en metálico para armonizar debidamente los intereses de unos y otros, y que á la vez que pongan á los arrendatarios al abrigo de las oscilaciones en la voluntad de los propietarios garanticen en parte la normalidad de los beneficios que resulten, y los gastos que inviertan en las mejoras de los predios que cultiven.

\section{XXVII.}

Siendo un hecho bien significativo que para los labradores son cada vez más ruinosos los precios del trigo, así como para los ganaderos los precios de sus reses, mientras que los del pan y los de la carne más elevados para los consumidores, los Ayuntamientos, en particular los de poblaciones mayores de 1.000 habitantes, consignarán en sus respectivos presupuestos la cantidad necesaria para premiar anualmente á los panaderos que elaboren pan de primera calidad, cuyo precio guarde más relación con el del trigo y su peso sea más exacto; así como á lus vendedores de carnes que expendan éstas en mejores condiciones y más en armonía con el precio de las reses, á fin de aumentar por tal medio el consumo de $\tan$ indispensables 
artículos; debiéndose publicar por anuncios y pregones en cada población, y por edicto en los periódicos locales que hubiere y en el Boletin Oficial de la provincia los nombres de los vendedores que resulten premiados.

\section{XXVIII.}

Reformar la ley de Reclutamiento $y$ Reemplazo del Ejército de II de Julio de т 885, en sentido de apartar de la resolución definitiva de los Ayuntamientos y Diputaciones provinciales, las excepciones y exenciones que aleguen los mozos interesados; y restablecer, al propio tiempo, la forma de los sorteos, con objeto de que éstos se efectúen como antes por los Ayuntamientos respectivos y no por zonas, para que cada pueblo contribuya con arreglo al número de mozos alistados, evitando por tal medio que de algunas poblaciones vayan al servicio de las armas todos los mozos útiles y de otras ninguno. Asi imperiosamente lo aconsejan y requieren de consuno la equidad, la lógica, el buen sentido, la razón y la justicia, à fin de que en la tributación de sangre la más sensible y dolorosa, á la vez que la más sagrada y patriotica, no se cometan los abusos, inmoralidades y escándalos que ha denunciado la prensa (aunque infructuosamente por cierto); y si por tal circunstancia las redenciones á metálico fuesen mayores,

Crisis agrícola. 
aumentarian los ingresos del Tesoro, y muchos infelices y honrados trabajadores que sufren las consecuencias de extraños abusos. y torpes manejos, podrian dedicarse con aprovechamiento al cultivo de los campos.

\section{XXIX.}

Favorecer la industria nacional, particularmente la que se halle relacionada de un modo directo con la agricultura y ganadería, pues el obrero español es un elemento de primer órden, reune las mejores cualidades. tanto para los trabajos agricolas como para los industriales; y en España sobran iniciativas, capitales, arrojo y patriotismo para afrontar ciertas industrias y empresas, por importantes y arriesgadas que sean, como las de construcciones navales, vias férreas sin subvención del Estado, fabricas y cualquier otra que signifique progreso, movimiento y bienestar; siempre que en vez de entorpecimientos y tributos, encuentre apoyo y protección por parte del Gobierno.

\section{$\mathrm{XXX}$.}

Para disfrutar algún beneficio, ú obtener la concesión de cualquier empresa, serán preferidos los españoles á los extranjeros no naturalizados en España; à no ser que éstos aporten al Estado más positivas ventajas, ó formen sociedad con algún español, acreditando cumplidamente uno y otro extremo. 


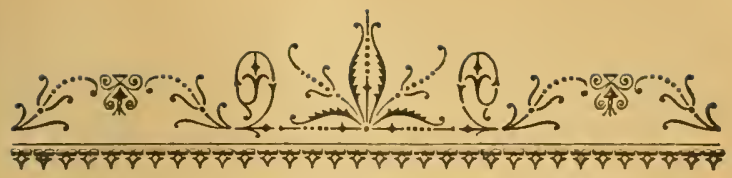

\section{PAPIE GUART:}

NUEVOS INGRESOS.

\section{CAPÍTULO ÚNICO.}

1. Impuesto sobre la renta.

2. El interés sobre el préstamo.

3. De los empleados y funcionarios públicos.

4. El impuesto de cédulas personales.

5. Faltas de asistencia á las escuelas de instrucción primaria.

6. Matriculas y titulos académicos.

7. Las nuevas plantaciones de vides.

8. Falsificadores y adulteradores de vinos.

9. Corridas de toros, becerros, novilios $\mathbf{y}$ vacas.

10. Los velocipedos.

11. La blasfemia.

12. La prensa mercantil.-Lances de honor, crimenes y suicidios.

13. Insinuación de otros vários.

14. Advertencia ó disposición final.

Todo lo que conduzca á la imposición y exacción de tributos aparecerá sensible y odioso; de la propia manera que para los 
contribuyentes es grata y halagüeña cualquier rebaja, en particular si es de alguna entidad ó importancia.

Sin pretender otra cosa que la consecución de una verdadera equidad tributaria, proponemos todo cuanto al afecto conceptuamos que puede establecerse y modificarse; no para extinguir con ello la Deuda pública (cuyo medio seria de verdadera eficacia para consolidar nuestro crédito), ni para llegar á la rebaja gradual de toda clase de tributos, sino para compensar la baja correspondiente al impuesto que grava los vinos y facilitar recursos para el pago de primas y recompensas mencionadas en los capitulos anteriores, con lo cual se aliviará notablemente la aflictiva situación de la clase agricola. Además, si con los ingresos de que nos ocupamos en el presente capitulo (así como de otros que se estimen conducentes) se obtuviere algún sobrante, en tan anhelado caso podría destinarse á la construcción de nuevas vias férreas, carreteras, canales de riego, y de navegación, saneamiento de terrenos etcétera, para dar más fácil salida á los productos nacionales y colocación á la clase obrera.

Tal vez no rindan cantidades considerables algunos tributos de los que hacemos referencia, pero tampoco las rinden el impuesto sobre la pólvora, cerilias fosfóricas, 
carruajes de lujo y otros, y sin embargo han sido, con mucha razón y justicia, recientemente establecidos. La adopción de impuestos indirectos, es, á no dudarlo, práctica $\mathbf{y}$ beneficiosa, $y$ en las naciones cultas más adelantadas en Administración que la nuestra, constituyen aquéllos una fuente abundante y el más fecundo manantial para sus respectivos presupuestos. Para allegar recursos al Tesoro, sin perjudicar ningúa elemento de riqueza, conviene utilizar los ingresos indirectos de que se pueda disponer, por insignificantes que sean; pues como dice el antiguo adagio castellano, un grano no llena el granero, pero ayuda á su compañero.

Nuestros propósitos, si es que llegan à ser conocidos por los hombres de gobierno y eminentes hacendistas (con quienes no osamos competir, pues no llegaría jamás á tanto nuestro atrevimiento, ni dejaria de ser una locura pretenciosa el colocar nuestro modesto trabajo al lado de sus grandes obras y de su ilustración privilegiada), tal vez sean calificados de un simple proyecto, tanto por su fondo como por sus formas, impracticable y estéril. Sin embargo, no creemos que merezca la calificación de un desatino de gran bulto, $y$, si asi fuere, repetimos en esta parte, la mas espinosa y delicada de nuestra obra, que obedece, como todas nuestras humildes observaciones, ai. propósito decidido de 
fomentar la producción nacional, y muy singularmente la riqueza agricola, que es hoy la más abatida y necesitada de urgentes y eficaces remedios, siguiendo para ello los impulsos de nuestra conciencia; pero sin ánimo el más remoto de herir susceptibilidad alguna, ni de perjudicar intereses de ningún género, como tampoco de hacer de mejor condición los de una clase que los de otra; pues anhelamos que todos se desarrollen y prosperen, á fin de que en todo caso pueda excogitarse lo bueno, si lo hubiere, para que el Erario encuentre compensación sobrada, como ya hemos dicho, por lo corespondiente á las recompensas propuestas, y al impuesto sobre los vinos, de cuya supresión nos hemos ocupado con algún detenimiento (1), por considerarla absolutamente necesaria en las circunstancias actuales para evitar la completa ruina de tan importante ramo de nuestra riqueza pública.

Asi, pues, á continuación detallamos los elementos que entendemos deben aportará la tributación su parte proporcional, conforme á la masa de utilidades que los mismos representan; y la parte que estimamos pre. cisa para contener, ya que no evitar en absoluto, lamentables errores y abusos, dando principio por el

(1) En la Parte 2.', cap. I. 


\section{Impuesto sobre la renta.}

El ideal de la ciencia económica es que la atributación grave por igual todas las manifestaciones de riqueza.

La Constitución de la Monarquia, en su art. $30^{\circ}$ preceptúa que todo español está obligado à contribuir en proporción de sus haberes. Fundamento sublime, precepto sábio, principio sólido y equitativo, por todos reconocido, sin que hasta ahora haya llegado á tener cumplimiento.

Sabido es, que hay muchas fincas rústicas hipotecadas para pago de deudas, y otras embargadas y vendidas por el Estado por débitos de contribuciones; pues à los agricultores tengan ó no recursos, se los pone en el duro trance de pagar sus cuotas por trimestres y en dias tijos; y hoy que la agriculcultura agoniza, el comercio sucumbe, la industria perece, el jornalero emigra por carecer de trabajo, y que una miseria espantosa reina en algunas comarcas españolas, no vemos otro remedio mejor para aliviar y contener los muchos males que el país lamenta, que cumplir el precepto constitucional, á fin de que cada español contribuya en proporción á las rentas que disfrute.

El Sr. D. Juan de Dios Blas, tan competente en estas materias, en un articulo interesante, como todos los suyos, después de 
demostrar que la propiedad ha perdido 9.600 millones de pesetas desde 1882 , mientras. que los tenedores de la Deuda han ganado desde 1876 la enorme suma de 3.144 millones. efectivos, y de reconocer que es necesario y justo el impuesto sobre los intereses de la Deuda, y la primera y principal solución para nivelar el presupuesto de la nación y el del Estado, dice: "Y tenga en cuenta el Gobierno y los tenedores de la Deuda, que esta solución vendrá, pero que si tarda, causará los mismosefectos que en Portugal, y perderá la nación y los mismos tenedores. Con impuesto á los intereses de la Deuda interior y exterior y el pago de ésta en moneda circulante en la nación, hay probabilidades de que podamos conjurar la crísis, y sin ello es. imposible, y segura la ruina del pais y de la misma Deuda... Tal vez habrá algunos que extrañen no presentemos más soluciones. principales que el impuesto sobre la Deuda para nivelar el presupuesto del Estado, y la protección á la industria y gricultura para nivelar el presupuesto de la nación; pero á los que esto digan les contestaremos por adelantado, que nos citen á muchos economistas que creen arreglar la Hacienda con un discurso optimista, ó con un artículo encomiástico de lo que ha hecho ó va á hacer el Gobierno, de los muchos que aparecen en los periódicos ministeriales». 
En verdad que hoy son necesarias leyes más que discursos, y hechos más que palabras; porque el agricultor como el industrial, comerciante y el pais entero, desea obras más que promesas, pero obras generadoras que salven á España de la ruina que le amenaza; y nada más justo, equitativo y razonable que llamar á tributar los intereses de la Deuda, particularmente los de los titulos que están en manos de españoles; pues en cuanto à los acreedores de la Deuda exterior, como no disfrutan de ningún servicio de nuestra nación, el Estado juzgará conducente respetar las obligacinnes que tenga contraidas, que por ningún concepto pueden existir tratándose de la Deuda intericr, por más que una y otra se hallen, en su casi totalidad, en poder de capitalistas españoles.

Ya se adopte en definitiva el sistema prusiano, estableciendo como base el total de las rentas que disfrute el contribuyente, ya el sistema inglés en que cada clase de renta es objeto de una imposición especial, lo conveniente, y más aún lo indispensable y preciso es establecer desde luego un impuesto verdad (I), sobre los intereses ó dividendos

(I) Pues en nuestro cencepto no lo es el de 1'25 por 100 creado por el art. 56 de la ley de 30 de 'Junio de 1895 , en equivalencia del establecido por el artículo 43 de la ley de 5 de Agosto de 1893, para la 
anuales de todas las Deudas y valores nacionales; cuyo tipo podria alterarse en alza ó en baja, según las circunstancias lo requieran y demanden, pero siempre en harmonía con lo que en su caso se aumente ó disminuya á la propiedad territorial, à las industrias y profesiones (tanto del órden ciril como judicial), à las artes y oficios, y à cualquier otro signo ó elemento de riqueza contributiva.

No es que propongamos un tipo de imposición elerado como el establecido en Grecia y Portugal; pero si un quebranto ó impues. to análogo al que en la actualidad se paga en Italia, que no llega al I 4 por Ioo(1), y que

circulación de los títalos de la Deada perpétuz interior y amortizable y sobre los valores mercantiles é industriales $y$ de Corporaciones; como tampoco seria gravámen rerdad sobre la riqueza rústica, pecuaria y urbana si solo se las impusiere el referido tipo de 1625 por 100 de sus rerdaderos rendimientos.

(1) Jayor es el tipo señalado á la riqueza rústica y peruaria, que ya es sabido asciende á $15 ' 50$ por 100 para los pueblos conrenidos y á $20 \cdot 25$ para los demás. La riqueza urbana á 17 ‘0 y 23 por 100 respectivamente, según sean ó no conrenidos; mientras que en Francia, es solo de 3'20 por 100 sobre la renta de la propiedad agrícola, y 4 por la arbana. En Prúsia los pequeños propietarios contribugen sólamente á razón de un 3 por 100 de sus rentas, y de 4 por 100 los que disfrutan de 11.000 marcos de renta en adelante. 
guarde la debida proporción con lo que pagan los demás elementos ó manifestaciones de riqueza, pues asi lo requieren de consuno la equidad y la justicia y lo demanda con insistencia imperiosa la opinión pública.

El gravamen impuesto á la riqueza rústica, pecuaria, y urbana, à la industria y al comercio, á las profesiones, artes y oficios; cupos de consumos, derechos reales, descuentos sobre sucldos y haberes, etc., etcétera, se ha elevado hasta la mayor presión del vapor Hacienda, y ya no es posible elevarle un grado más, ni aún sostenerle mucho tiempo en tan candente y peligroso estado, sin exponerse à que estalle la caldera y produzca una terrible catástrofe.

La riqueza mobiliaria, es la úniça que hoy se sustrae al precepto constitucional, la única que disfruta de un privilegio tan injusto é irritante y la única que goza de una excepción que se convierte en carga abrumadora para cuantos elementos contribuyen á levantar las cargas del Estado, con notorio perjuicio de los mismos y singularmente de la agricultura; pues faltando en ésta colocación á los capitales, por ser la que menos produce, es lógico que se tienda la vista hácia los

La inversa sucede en las rentas de los valores públicos: en España los intereses de la Deuda producen un 6 por 100, y en Francia, Inglaterra y otras naciones no producen más del 3. 
valores que rindan mayor interés y ofezcan más seguridades.

Si al que después de dos años de continuos afanes y trabajos, de sostener numerosos jornaleros y prestar infinidad de servicios logra obtener un rendimiento insignificante (y aun sin obtenerle, como sucede muchosaños que en vez de beneficios notienen más que pérdidas), se les impone una tributación excesiva, no hay, no puede haber razón alguna para que se le exima de ella al que libre de gastos de cultivo, de plagas, sequías, inundaciones y demás calamidades que arrebatan los frutos del campo, causando la ruina del agricultor, le garantiza el Estado un interés crecido para que le perciba sin molestias ni obligaciones.

Los hombres que viven rodeados de lujo, de ostentación y comodidades, deben contribuir en igual porción, por lo menos, que aquellos que trabajan y ganan el sustento con el sudor de su frente; pues más licito es que pague el que mucho percibe, que el pobre que apenas tiene el triste bocado de pan con que alimentarse.

En vano se recurre á los más ingeniosos sofismas para sostener una desigualdad tan notoria, una preferencia tan injustificada, una excepción que se aparta en absoluto de la verdadera equidad, un privilegio tan en pugna con los principios elementales de 
justicia, y que, si la leyle sanciona, la conciencia le rechaza.

Más de esperar es, que los mismos tenedores de la Deuda pública se persuadan también de que los interesa la adopción del mencionado impuesto para evitarse perjuicios seguros y consolidar su crédito en el porvenir; y que no habrá de faltarles patriotismo, ni han de ser tan egoistas que se oponganá lo que exigen la razón, la equidad y la justicia, y á lo que se halla establecido en otras naciones, ya sea su respectiva situación económica màs próspera ó más comprometida que la nuestra.

Cuando de los 767 millones del total general del presupuesto de gastos del Estado, paga éste 318 por intereses de lá Deuda pública, muy cerca de la mitad del presupuesto de la nación, y viendo el ejemplo de S. M. la Reina, que contribuye con su donativo de un millón de pesetas; el Clero y Monjas con otro donativo de más de 3 millones; que se ha establecido un impuesto sobre todos los sueldos y asignaciones de los empleados del Estado, provinciales y municipales, aún cuando aquéllos sean tan mezquinos como los inferiores à mil pesetas al año; los contribuyentes por territorial é industrial apremiados por la fuerza armada para el pago de las cantidades porque aparecen en descubierto, no por falta de buenos propósitos, 
sino por carecer de recursos, hasta los mejor acomodados; los cambios en ruina permanente; y los jornaleros sin trabajo para ganar el sustento diario, no habrán de estar, repetimos, los poseedores de títulos rentisticos tan faltos de patriotismo que, en vez de facilitar por su parte la regeneración económica del pais, vayan á imitar á Sansónal derribar las columnas del templo para perecer entre sus ruinas con todos los filisteos.

Por otra parte, la adopción del impuesto directo sobre la renta, pudiera contribuir para dentro de un plazo más ó menos inmediato á encauzar alguna parte de esos enormes capitales á la explotación de fincas agrícolas, á establecer nuevas industrias y á importantes mejoras para el fomento y desarrollo de la producción nacional.

\section{$\mathrm{El}$ interés sobre el préstamo.}

Lo propio que respecto al impuesto sobre los valores públicos, decimos de los préstamos: todo lo que produce debe contribuir.

Los préstamos constituyen otro elemento de riqueza y producción para los prestamistas, sustraidos hoy, en su inmensa mayoria, à la tributación.

Los prestamistas con establecimiento abierto al público, los que prestan con hipoteca, $y$ los que en escritura pública consignan los 
intereses convenidos (muy pocos por cierto), son los únicos que no pueden sustraerse á la acción del Fisco. Todos los demás utilizan pagarés ó recibos, evitándose por tal medio gastos de papel sellado, de Notario, y muy principalmente el impuesto debido á la Hacienda. La mayor parte de los contratos de esta indole carecen de publicidad, y en ellos se acumulan al capital los intereses estipulados; por cuyo sencillo medio eluden el pago de los derechos establecidos.

Prestamistas sobre granos, caldos y frutos hay muchos; son los que hacen las cosechas más crecidas y seguras; y sin embargo no sabemos de ninguno que figure en las matriculas de la contribución industrial.

Por la ley de 14 de Marzo de 1856 quedó abolida toda tasa sobre el interés del capital en numerario dado en préstamo, y desde entónces puede ya pactarse libremente en los préstamos el interés que estipulen las partes contratantes.

«El ocho ó el diez por ciento se tienen por rigorismo en la observancia de la justicia. Interés tan bajo no le suelen llevar sinó los que se proponen negociar con sus ahorros, y no han sido presa aún de la avaricia, ni llegado hasta la profesión de usereros (1)).

(1) Martínez y González, en su mencionada obra. 
Entendemos que cuando el que tiene dinero lo arriesga y aventura para que le produzca, favoreciendo á la vez, al amigo, vecino ó extraño, nada más justo, lógico y procedente que perciba el interés módico, equitativo y razonable que permita la moral cristiana, y que también le produciria en la explotación de una industria, en fincas, frutos ó valores públicos; pero no así los préstamos escandalosos al 15, 20 y aún al 30 por ioo anual, ya sean en granos, caldos ó metálico que huyen de la luz pública, buscando en el pagaré, ó en el recibo las tinieblas que encubran tamaños abusos (r).

Gallo que no canta, algo tiene en la garganta, dice un antiguo adagio; y otro, el que quiera andar librey seguro pague al rey lo que sea suyo. Pues si entre dos males hemos de optar por el más pequeño, ya que las leyes civiles autoricen y sancionen los pactos mencionados, los que se lucran'de tan crecidos intereses, que paguen siquiera á la Hacienda el impuesto correspondiente.

Para ello conceptuamos necesario:

1. Establecer un tipo prudencial de tributación para los préstamos de cualquier clase, no expresados en el reglamento de la contribución industrial.

(1) Para evitarlos en parte, hemos propuesto la creación de Bancos agrícolas. 
2. Señalar un plazo para renovar, en el papel sellado correspondiente, toda clase de contratos sobre préstamos, y en cuyos documentos no conste el interés estipulado.

$30^{\circ}$ Disponer que una vez transcurrido el plazo establecido, sean presentados los documentos insinuados en la oficina liquidadora para el pago de los derechos à la Hacienda.

$4^{\circ}$ El acreedor que no presente los documentos que obren en su poder á la liquidación y pago dentro de los 30 días siguientes al de su otorgamiento, incurrirá en el recargo de un 50 por $100, y$ si demora la presentación, hasta los 90 dias, en el de un 100 por 100.

5. Trascurrido el plazo últimamente referido sin haber satisfecho los derechos á la Hacienda, se considerará caducado y sin ningún valor ni efecto el documento que acredite el préstamo realizado.

6. En los documentos que se consigne ser el préstamo sin interés alguno, satisfarán también los acreedores el impuesto que corresponda al interés del doble tipo legal (I) para cuando no medie estipulación alguna, ó sea à razón de un 12 por Ioo (2); sin cuyo

(1) Art. 11 (18 del Código Civil.

(2) Que algo más aún suelen percibir los que no hacen constar por escrito el interés estipulado.

Crisis agrícola. 
requisito no tendrán derecho á reclamar la devolución de los préstamos efectuados (I).

$7 .^{\circ}$ Los Jueces y Tribunales no admitirán. demanda alguna en reclamación de cantidades prestadas, sin que los interesados just:fiquen préviamente haber satisfecho los derechos à la Hacienda.

\section{De los empleados y funcionarios públicos.}

Los expedientes y reclamaciones de cualquier clase y condición que sean, deben despacharse por turno rigoroso, sin necesidad de seguirles como la sombra al cuerpo y el galgo à la liebre, ni obligar à que los reclamantes tengan que valerse de los Diputados ú otras personas intermediarias para que recomienden y recaben su pronta y justa resolución, cual si trataran de cunseguir una gracia de excepcional importancia.

(1) Bien quisiéramos poder proponer excepción del pago de derechos para los préstamos sin interés (si es que así se efectuare alguno, que será muy raro) como también para los que se realicen en metálico ó. valores de menos de 100 pesetas, pero entónces se expresaría en los contratos que todos los préstamos se hacían sin interés de ningún género, por más que éste sea elevado, y aun cuando fuesen de cantidades. considerables se fraccionarían en partidas menores á las que se exceptuasen del pago, con lo que resultaría completamente ilusorio el impuesto que llegara á establecerse. 
Suele ser frecuente tâmbién preguntar por el estado de un expediente cualquiera, sin que nadie dé razón de él, y después de muchas vueltas, si llega a parecer, lo es lleno de polvo, pues no es el primero que ha sufrido extravio.

Para evitar tan graves inconvenientes, en todas las oficinas municipales, provinciales y del Estado, se llevará un libro-registro de entrada de documentos, en el que se anotará por turno y con numeración correlativa el expediente, reclamación ó documento que ingrese en la oficina, expresándose el nombre del reclamante, persona ó autoridad que le presente ó remita, negociado á que pertenece, Jefe del respectivo servicio que de aquel se haya hecho entrega para la tramitación correspondiente, debiendo firmar el recibi del mismo en un indice por duplicado que conservará el encargado del registro para que le sirva de resguardo.

El registro y entrega de documentos deberán hacerse en el mismo día que aquellos sean entregados al encargado de dicho trabajo, cuidando de marcar con el sello del registro todos los documentos que haya de registrar, anotando además en la cabeza ó parte superior de los mismos el libro y fólio en que han sido registrados.

El registro general tendrá el carácter de documento público, y podrá ser examinado 
libremente por cuantas personas lo deseen; debiéndose facilitar lns datos, informes ó certificaciones que con referencia al mismo soliciten los interesados.

Recibidos los documentos, el funcionariu respectivo evacuará sin levantar mano todas las diligencias y preceptos reglamentarios para la tramitación debida, á cuyo efecto informará proponiendo la resolución que estime procedente, fundándola en la doctrina legal que corresponda, y citando las disposiciones que sean aplicables á cada caso con todos los detalles precisos, para que sin dificultades puedan llevarse aquellas á completo término, con lo cual quedará á salvo su responsabilidad.

Los ordenadores de pagos no acordarán los de las nóminas ó libramientos de empleados y funcionarios públicos, si no justifican préviamente tener informados, resueltos y ejecutados, en la parte que á cada uno corresponda, todos los asuntos propios de su respectivo cargo; y si alguno hubiere pendiente de resolución ó despacho, habiendo transcurrido el término reglamentario para ello, por esta sola circunstancia el sueldo que cada uno de aquellos deba percibir, quedará en beneficio del Erario.

Si algún ordenador de pagos faltare al requisito mencionado, incurrirá por cada caso en la multa de mil pesetas, que satisfará 
en papel de pagos al Estado; y otra multa igual en efectivo metalico para la parte denunciante, si debido à ésta se descubre la infracción cometida.

A los Tesoreros ó Depositarios-pagadores no les servirá de abono en sus cuentas los pagos que realicen sin la formalidad expresada.

Los Alcaldes, Concejales, Diputados provinciales y vocales de las Juntas que desempeñan cargos honorificos y gratuitos incurrirán en la multa de 100 pesetas por cada asunto, reclamación ó expediente que no resuelvan dentro de los plazos legales.

Los empleados y funcionarios de cualquier clase y condición ya desempeñen cargos retribuidos ó gratuitos que reincidan por tercera vez en las faltas insinuadas ó en la comisión de algún abuso ó trasgresión, además de las referidas multas, quedarán inhabilitados absolutamente para el ejercicio de cargos públicos; sin perjuicio de las demás responsabilidades que procedan, y de la indemnización de daños ocasionados, cuyo derecho podrán ejercer los que resulten perjudicados.

El impuesto de cédulas personales.

Los documentos que hoy conocemos con el nombre de cédulas personales, fueron en su origen de vecindad, pues desde 1854 sus. tituyeron a los suprimidos pasaportes para 
el interior, y de documentos de seguridad y de vigilancia en los que se hacian constar las señas generales y particulares de cada interesado, á fin de identificar su personalidad en el momento que fuere preciso, han pasado á ser documentos de carácter casi exclusivamente fiscal ó de impuesto; y ya es sabido que su objeto principal y pudiéramos decir que único, es el de acrecentar los ingresos del Tesoro público.

La instrucción vigente de 27 de Mayo de 1884 para la administración y cobranza del impuesto de cédulas personales, urge reformar á fin de que desaparezcan las muchas incoherencias y discordancias que contiene, y para establecer en este impuesto (ya que es uno de los más odiosos y desiguales, que afecta á la inmensa mayoría de los españoles, y que, por lo tanto, más se trata de eludir), el principio de una verdadera equidad tributaria, con el objeto de exigir un mismo tanto por 100 sobre las utilidades de los obligados á contribuir por el mencionado concepto.

La escala gradual que hoy rige es harto limitada y muy desproporcional, y por consiguiente es necesario ampliar á otra más extensa y variada para acomodarla con la debida equidad y de un modo más uniforme á las distintas fortunas, á los diversos haberes, utilidades y conceptos de las diferentes 
clases de contribuyentes sujetos al expresado impuesto.

La tarifa núm. I, para la exacción de este impuesto, establece que los que paguen anualmente por una ó varias cuotas de contribución directa 25 pesetas, están obligados á proveerse de cédula personal de 2 '50 pesetas, y de igual clase los que pagan 1300 pesetas! cuya desproporción no puede ser más absurda, depresiva é irritante para los muchos contribuyentes de clase inferior que por los ganados de labor ó por los reducidos predios que cultivan en renta pagan de 25 á 5o pesetas, y se les obliga á adquirir cédula de igual clase que á los propietarios que pagan 300: observandose análoga desproporción en las demás escalas, lo mismo en las relativas á contribuciones, que en las de sueldos é inquilinatos.

Es, pues, indispensable que desaparezcan las enormes desigualdades de las categorias y precios de las cédulas entre las diversas clases sociales obligadas á contribuir por tal medio y ampliar á 20 clases por lo menos las II hoy existentes para elevar el valor de las cédulas correspondientes á la categoria $\mathbf{I}_{0}$ "á 500 pesetas, y en idéntica proporción las demás clases subsiguientes, siquiera hasta las ocho primeras, relativas á las clases mejor acomodadas que son las que más beneficiadas se hallan por las tarifas vigentes. Pero 
todavía más equitativo y de mejores resultados para el Estado y los Ayuntamientos, y para que no falte esa igualdad niveladora que aconseja el principio fundamental de que cada cual contribuya con arreglo á sus haberes, será establecer una escala que señale:

En contribuciones directas, el 4 por 100 sobre las cuotas del Tesoro.

En los sueldos y en los haberes ó utilidades de todas clases el 1 por 100.

Por alquileres: en Madrid el I'75 por 100.

En las demás capitales de $10^{2}$ clase, el 2.

En poblaciones de más de 30.000 habitantes, el 2'50.

En las de 15 á 30.000 , el 3 .

En las de 6 á 15.000, el 3'50.

En las de 2 á 6.000 , el 3'75.

En las restantes, el 4 .

Si además los arriendos se hicieren por partidos judiciales, y si posible fuere, por Ayuntamientos ó distritos municipales, mejor que por provincias; el impuesto que compreńda á los mayores de 12 años; y que todos los cabezas de familia se provean para sus mujeres é hijos de cédula personal, sinó de igual clase, por lo menos de otra algo aproximada y más en harmonia a la posición social de cada uno (1), no vacilamos el ase-

(1) Pues el exigir á la señora de un fuerte hacendado ó rentista en gran escala cédula de igual c'ase 
gurar, sin temor a que se nos tache de exagerados, que tanto el Tesoro público como los Municipios obtendrán doble producto que el que hoy obtienen del impuesto de cédulas personales.

Faltas de asistencia á las escuelas de instrucción primaria.

Para corregir las faltas de que se trata, los Alcaldes constitucionales con referencia al padrón de habitantes, remitirán á los profesores de instrucción pública en los primeros días del mes de Enero de cada año, una lista detallada de los niños que tengan cinco á diez años de edad, con expresión del dia de su nacimiento. En las poblaciones de más de diez mil habitantes será cargo de los Alcaldes de barrio respectivos la remisión de la lista indicada.

Los profesores de enseñanza primaria incluirán en el libro de matricula á todos los niños comprendidos en la lista referida; y si tuvieren noticia de haberse omitido alguno

que á su criada, nos parece un privilegio en favor de la fortuna, y tan poco equitativo como el obligar á los jornaleros á proveerse para sus hijos de cédula de igual clase que á los grandes potentados para los suyos. 
le incluirán también en matrícula, comunicándolo asi al que hubiere expedido aquella para la adición correspondiente.

Los padres de familia están obligados à mandar á la escuela de enseñanza primaria todos los hijos que tuvieren comprendidos en la edad de seis á diez años ambos inclusive. Cada día ó falta de asistencia será corregida con una peseta de multa, de cuyo pago serán responsables los padres respectivos.

Los padres que tengan sus hijos cursando en otro colegio ó centro docente del que corresponda à su pueblo ó distrito, ó bien en su propia casa al cargo de preceptor, lo acreditarán el último día de cada mes, con certificación expedida por el director ó preceptor respectivo. Los que se hallaren enfermos serán dispensados de las faltas de asistencia, siempre que asi lo acrediten sus padres ó encargados también el último día de cada mes, con certificación expedida por"el médico que le asista ó haya asistido en su enfermedad.

Hechas las alteraciones que correspondan por el resultado de las certificaciones recibidas, y de las altas ó bajas que, por traslado de vecindad j fallecimiento le fueren comunicadas, ó le constaren de ciencia propia, los profesores remitirán á la Junta provincial de instrucción pública respectiva el día primero de cada mes una lista duplicada del número 
de faltas de asistencia de los niños matriculados en la escuela de su cargo, durante el mes anterior.

Dentro de los cinco dias siguientes al dé su recibo, los Gobernadores de provincia remitirán un duplicado de la lista recibida á los Alcaldes respectivos, previniéndoles que dentro del propio mes, y con cargo á los fondos municipales acrediten haber ingresado, á disposición de la Hacienda, la cantidad total á que asciendan las multas por las faltas expresadas; y si no lo hicieren serán apremiados sin consideración de ningún género.

De las cantidades satisfechas por el mencionado concepto, los Ayuntamientos podrán reintegrarse de los padres, cuyos hijos hubieren cometido las faltas de asistencia á la escuela. Si algún padre ó encargado de familia resultare insolvente, para indemnizarse los Municipios tendrán derecho á imponerle un dia de trabajo en las calles y caminos del término, por cada dos de las citadas faltas. Asi se conseguirá además arreglar las vías públicas y evitar en parte los crecidos gastos que, con tal motivo (y en algunos casos pretextos) merman los presupuestos municipales.

Los Ayuntamientos que no tengan cantidad consignada en su presupuesto ordinario para el pago de las supradichas multas, 
podrán acordar las trasferencias que estimen necesarias, y si no fueren suficientes, formarán, por los trámites legales un presupuesto extraordinario.

Matrículas y títulos académicos.

Son tantos los títulos expedidos por el ministerio de Fomento en pocos años, que, de continuar asi algunos más, vamos á tener que contar más abogados que litigantes, médicos que enfermos, y otros muchos hombres titulados, sin más porvenir que los destinos públicos à que necesariamente habrán de apelar, quiza con la sana intención de que estén mejor servidos; pero la experiencia nos enseña que muchos de los que ván desde las universidades á desempeñar destinos en las oficinas, carecen de los conocimientos más interesantes acerca de la organización administrativa del pais, y que necesitan casi otros tantos años como los invertidos en la carrera para desempeñarlos con acierto.

¡Y cuanto mayor bien se harian asi mismos, á sus familias y à la sociedad, si la inmensa mayoría dedicara su poderosa iniciativa y su inteligencia al estudio de la agricultura, á la noble profesión de cultivar los campos!

Como uno de los medios de cohibir en parte uno de los mayores errores de nuestros labriegos, en perjuicio de la agriculturd, y de 
facilitar, al propio tiempo recursos para el Tesoro, convendrá aumentar el doble de la cantidad que hoy pagan por derechos de matricula de asignaturas y títulos académicos todas las profesiones y facultades, con excepción de la de Ingenieros agrónomos, peritos y capataces agrícolas, y cualquier otra relacionada de un modo directo con la agricultura.

Las nuevas plantaciones de vides.

No es que esperemos por ahora grandes rendimientos en favordel Tesoro público por el aumento de tributación á las nuevas ó futuras plantaciones de vides, porque los agricultores van persuadiéndose y tocando prácticamente las funestas consecuencias del grave error que cometieron; pero como todas las zonas ó regiones no se encuentran en igualdad de circunstancias, y si bien en muchas hay verdadera plétora de producción, en otras no sucede lo mismo y es probable que continúen las nuevas plantaciones, con grave detrimento de las demás comarcas y del equilibrio que debe resultar en la producción, ya que no se establezca una prohibición absoluta como quiza fuese conveniente (I),

(1) Como ya la decretaron Licurgo y Domiciano; cuya prohibición subsistió mucho tiempo en Italia, Francia, Hungría y particularmente en Espaía cuando 
que contribuyan por aquellas que las realicen con mayor cuota ó tipo de gravamen, que además de lo que satisfacen en la actualidad, podría consistir en 100 pesetas anuales por cada hectárea de terreno que plantasen en lo sucesivo.

Falsificadores y adulteradores de vinos.

Ya hemos demostrado (I) que la grave crisis porque atraviesa la riqueza vinicola, consiste en primer lugar en el exceso de producción de tan importante artículo de consumo, y que éste exceso resulta considerablemente aumentado por consecuencia de la escandalosa fabricación de vinos artificiales y la adulteración de los naturales, lo cual origina además la desconfianza del público y hace disminuir el consumo de una bebida tan sana y confortante como es el vino puro.

Tanto se ha generalizado la sofisticacion de los vinos que es muy raro el natural ó puro que se expende al público. En proporciones increibles está almacenado en los grandes centros, en las pequeñas aldeas, y hasta

nuestra pátria fué una de las provincias del Imperio romano.

Los reyes Católicos, después de la conquista de Granada á los moros, prohibieron que en ella se plantasen viñas.

(1) En la Parte 2." cap. I. 
en los simples ventorrillos. Ya nadie necesita estudiar quimica para confeccionar mixturas colorantes y dañinas, y venderlas después con el nombre de vinos en detrimento de los consumidores y de la viticultura.

El agiotista no paga contribución Territorial, ni Consumos. Cuando figura en matrícula como industrial, lo es por otro concepto y por una cuota insignificante, mas nunca por las utilidades positivas que le resultan. Con su tráfico ilegal ocasiona también la escasez de jornales, perjudicando así á multitud de obreros, y privandolos del sustento. diario que necesitan para si y sus familias.

Desde el 24 de Agosto de 1894 ha comenzado á regir en Francia la titulada ley del movillage, con el objeto de evitar las muchas adulteraciones de vino tan perjudiciales á la salud pública, como á los agricultores de buena fe, procediendo con el mayor rigor contra los fabricantes y expendedores de vinos sofisticados.

Es, pues, necesario emprender en España una activa é incesante persecución contra los sofisticadores de vinos, á fin de que renazca la confianza en los mercados nacionales y extranjeros, y evitar los casos de envenenamiento y de locura que aquellos producen con su venenoso secreto y seguro, causando en la sombras numerosas victimas.

Salus populi suprema lex. 
Pues bien, la salud pública y la riqueza vitícola exigen de consuno la adopción inmediata de medidas enérgicas encaminadas á evitar en lo posible, y corregir los funestos extragos que ocasionan. los agiotistas de vinos.

La ley de 27 de Julio de 1895 prohibe la fabricación de vinos artificiales y dispone en su art. $20^{\circ}$ que se apliquen las penas establecidas en el art. 356 del Código penal para todas las alteraciones nocivas á la salud, á todo f.echo de fabricación artificial; cuya plausible medida venian reclamando con insistencia imperiosa la salubridad pública y la producción vinícolà. Pero no basta el sabio precepto de la ley, sinó que es preciso se observe con el mayor rigor, y que á los infractores se aplique el Código penal sin consideración alguna (I).

(1) El Real decreto de 11 de Marzo de 1892, refrendado por el Sr. Linares Rivas como Mlinistro de Fomento, prohibió designar con el nombre de vino cualquier otro producto que no fuese el líquido resultante de la fermentación del zumo de la uva, sin adición de sustancias extrañas á las componentes de la misma, así como la fabricación artificial y la adulteración de los vinos naturales, con otros varios preceptos referentes á la elaboración y conservación de los vinos, visitas de inspección, etc., y sin embargo no fueron cumplidas tan atinadas y previsoras disposiciones, cuya inobservancia cansó perjuicios enormes 
Es necesario además proseguir sin trégua ni descanso la adulteración de los vinos naturales, pues con el aditamento de agua, alcohol y componentes extraños al zumo y fermentación directa de la uva, se expenden aquellos al público en muy escandalosas proporciones, siendo aquella más difícil de corregir que la falsificación; y ya que el art. $4 .^{2}$ de la referida ley parece comprender también la adulteración, será conveniente conceder facultad á los cosecheros de vinos (y aún á los que no lo sean) para que asociados ó individualmente, sin perjuicio y con independencia de la acción judicial puedan fiscalizar y perseguir todos y cada uno de los casos tanto de falsificación como de adulteración, y con derecho á percibir un premio ó recompensa de 125 à 1.250 pesetas por primera vez y doble en caso de reincidencia que, como multa, pagarán los infractores.

Para que los procedimientos resulten breves, sencillos y eficaces, las denuncias deberán sustanciarse en cada localidad ante una Junta administrativa compuesta del Alcalde, Regidor-Sindico, Secretario del Ayuntamiento, el denunciante, denunciado y un

a la riqueza vinícola; por lo que mucho tememos suceda lo propio respecto de la ley ya citada y la Real órden del Ministerio de la Gobernación de 23 de Diciembre de 1895 dictada para el cumplimiento de aquélla. 
vecino designado por cada parte. Después que los interesados hayan expuesto lo que juzguen conveniente à su derecho, se retirarán del local, y la Junta, prévios los informes, pruebas y documentos que estime necesarios, dictará por mayoría de votos la resolución que corresponda. Los que se consideren perjudicados podrán interponer recurso de alzada para ante el Delegado de Hacienda dentro del preciso término de seis dias; pero los denunciados consignarán préviamente en la Depositaria municipal respectiva ó en las Cajas del Tesoro el importe total de las multas que les hayan sido impuestas. En caso de reincidencia se acordará también el cierre inmediato del establecimiento, fijando á la puerta del mismo una muestra ó cartel que diga: Cerrado por expender vinos aguados, (falsificados ó lo que fuere); publicando además la resolución en los periódicos locales y en el Boletin Oficial de la provincia á costa de los delincuertes.

En todas las capitales de provincia se conservarán los Laboratorios quimicos existentes y se establecerán donde no los haya con el personal y recursos necesarios para girar visitas á los establecimientos de la capital y pueblos de la provincia en que se expendan, elaboren ó almacenen vinos, y para practicar los análisis de los vinos, que remitan las autoridades administrativas y 
judiciales ó los particulares. Para los gastos que ocasione la instalación y sostenimiento de los expresados Labarotorios, los Ayuntamientos respectivos podrán formar un presupuesto especial que comprenda à los demás de la provincia, conforme á las circunstancias de cada localidad; ó de idéntica manera que con intervención de un Capitular por cada pueblo, lo verifican los alcaldes de la cabeza de partido judicial para los gastos relativos á corrección pública.

En Alemania se castiga severamente la adulteración, á cuyo fin se han creado agentes especiales de policia que vigilan constantemente los establecimientos en que se ejerce el tráfico de substancias alimenticias. En Austria se prohibe el empleo de materias colorantes en los vinos, $y$ en Inglaterra se prohibe el fraude y el engaño de vender un producto diferente del que el expendedor anuncia ó le atribuye, aún cuando el producto no sea nocivo.

En España es muy necesaria una asidua y escrupulosa vigilancia contra la adulteración por los muchos fraudes y abusos que se cometen, en perjuicio del público y de los vendedores de buena fé; y así como se castiga á los fabricantes y expendedores de moneda falsa, es necesario que se castigue también y con mayor rigor á los falsificadores y adulteradores de vinos, puesto que ocasionan 
perjuicios más enormes y de más difícil reparación que los falsificadores de moneda, billetes de Banco y documentos de crédito.

Corridas de toros, becerros, novillos

\section{$y$ vacas.}

Mucha es la afición que se ha desarrollado en España por la titulada Fiesta nacional, en la cual domina con frecuencia el desórden que se acomoda al vocerio, á las imprecaciones y á la fiebre delirante que se respira en aquella atmósfera insana que marchita la sensibilidad aún en las personas más finas y delicadas al observar á un pueblo que en el siglo de la civilización recibe placer en ver y hacer sufrir a séres inocentes. $\dot{e}$ indefensos.

Tristes reflexiones sugieren, en verdad, al contemplar un espectáculo tan poco edificante, particularmente las novilladas de los pueblos, en cuyas plazas, desnivelado el piso, sin barreras ni burladeros, sinó con carros llenos de gente se presentan á la lidia multitud de personas, aunque no sean diestras en el arte; originándose con tan lamentable circunstancia, derramamiento de sangre, la muerte ó lesión de varios de los que en aquella tomaron parte, y lo que es más doloroso, de algún pacífico espectador ó transeunte que por las malas condiciones de las vallas, 
ha tenido que sufrir también las consecuencias de la lidia. Cuantos más muertos y heridos resultan, más mérito tiene ésta; entregándose muchos espectadores á todo género de excesosque, para comprender su alcance, es necesario buscar en la historia la descripción de los espectáculos del antiguo circo romano.

Ya que están autorizadas en España las corridas de toros, vacas y novillos, no hemos de proponer la inmediata supresión de las mismas (I) persuadidos como lo estamos que las costumbres de los pueblos no se modifican de una plumada, sinó que es más conveniente dulcificarlas por medio del saludable espiritu de la tolerancia, procurando á la vez infiltrar en ellas la savia fecundante de la persuasión para elevarlas lentamente al mayor grado de cultura y perfección que sea posible. Por otra parte, no somos partidarios de gravar los espectáculos, ni aun los objetos de lujo, sinó las utilidades de todos y cada uno de los españoles al mismo ó por lo menos á un tipo aproximado de imposición; y atendiendo à que los lidiadores suelen obtener en breves dias considerables ganancias, como tambien los empresarios, estimamos

(1) Como en tal sentido se presentó en el Congreso de los Diputados una proposición de ley, con fecha 31 de Mayo de 1894. 
necesaria, equitativa y razonable una disposición que preceptúe lo siguiente:

"Por las corridas ó funciones de toros de muerte, las de novillos ó becerros, sean ó no de muerte, y las de vacas, se pagará por cada una triple cantidad de la 'establecida en la Tarifa $20^{\circ}$ núms. Io8 al Iro inclusive del reglamento para la imposición y cobranza de la contribución industrial de 11 de Abril de 1893 .

"No se autorizará ninguna corrida ó función de la indole expresada, sin que los Ayuntamientos respectivos acrediten haber consignado en su presupuesto de gastos la cantidad minima de 300 pesetas para el sostenimiento de una clase nocturna de adultos durante los meses del invierno, y sin que se hallen al corriente en el pago de esta deuda preferente, á fin de que los mismos adultos puedan recibir enseñanza gratuita. Con el propio objeto se aumentará igual cartidad por cada 2.000 habitantes en las localidades, cuya población exceda de éste número».

Tal vez á algunos les parezcan excesivas las cuotas prefijadas, pero á nosotros nos parecen, en uno y otro caso, bastante módicas; pues de una estadistica que tenemos á la vista aparece que en 1893 se celebraron en nuestra nación 581 corridas de toros, resultando un beneficio de 13 millones, y para 
los espadas y sus cuadrillas la considerable suma 1.420 .000 pesetas; beneficio que seguramente no han obtenido entre la mitad de los agricultores de España, después de dos años de incesantes afanes y'trabajos.

No esperamos, ni nos proponemos (por que nos agrada respetar los gustos, aficiones y costumbres de los pueblos) que con la adopción de tales medidas disminuya el número de espectáculos de la clase indicada, puesto que es una afición ya muy arraigada en muchisimos españoles; pero elevarán seguramente los derechos del Tesoro y se obtendrán mayores adelantos en la enseñanza, de la que es de esperar más provechosos resultados.

\section{Los velocípedos.}

El sport velocipédico vá extendiéndose en España, como se ha extendido en Francia, Austria, Inglaterra, Italia y singularmente en Bélgica.

El velocipedo que apareció en forma de juguete de niño, es hoy la máquina útil y puesta en moda con la que los aficionados recorren largas distancias eu breves horas (I) y obtienen premios honorificos, en

(1) Huret, recorrió en Julio de 1895 durante las 24 horas que duró la carrera en el velodromo Búffalo de 
metálico y en objetos de valor (I). No ya solamente los hombres, sinó hasta las señoras y señoritas más distinguidas y aristocráticas, después de vencidos ligeros escrúpulos y persuadidas de que el uso de la bicicleta en nada se opone á lo que exigen el decoro y las reglas de una esmerada educación, se dedican con verdádero entusiasmo á los higiénicos ejercicios del velocípedo.

Reconocida su mucha utilidad se aplica con el mejor éxito para la conducción de la correspondencia pública, y para ello puede

París, la enorme distancia de 829 kilómetros; y 851 en Burdeos el 15 de Septiembre del propio año, en igual tiempo, y con un calor de 40 grados.

(1) Zimmermam, famoso corredor americano, célebre volador como le llaman los ciclistas, los premios que ganó en Julio de 1894 en la carrera de París-Spá excedieron de 12.000 francos.

En la carrera del Campeonato de España verificada en Nadrid el 30 de Septiembre del referido año, el premio de 1.000 pesetas que ganó $D$. Manuel Lacasa le fué entregado dentro de una artística cartera con una corona y dedicatoria de plata. El que ganó el mismo Sr. Lacasa el 6 de Octubre de 1895 consistió en Medalla de oro.

Además han ganado premios, también en honrosa lid, los afamados corredores Pedrós, Campo, Lapuente, Gomila, Minué, Lozano y otros distinguidos ciclistas españoles. 
competir nada menos que con el ferrocarril (I): se usa también en el Ejército, reemplazando ventajosamente al caballo, y los velocipedistas militares lucen sus vistosos uniformes (2).

Mucho se ha generalizado y tiende á generalizarse cada vez más el uso de una máqui na tan útil para el buen servicio público y el de los particulares, y cuanto más se perfeccione aquella en seguridad y comodidad, más aplicación habrá de hacerse de la misma, ya que tanto se impone también por sus condiciones higiénicas (3).

(1) Dando excelente resultado, como lo patentizó la carrera-estafeta de Valladolid á Madrid verificada el 23 de Septiembre de 1894; pues los pliegos oficiales de las autoridades de Valladolid llegaron a Madrid en bicicleta tres horas antes que el tren.

(2) Los ingleses pueden presentar en línea un regimiento completo de triciclistas que maniobran como una verdadera unidad de combate.

Francia y Alemania estudian y reglamentan lo referente al ciclismo militar, y cuidan con el mayor interẻs de difundir la enseñanza velocipédica.

(3) El ilustrado periódico Le Monde Medical considera las moderadas excursiones ciclistas como el más higiénico ejercicio; y según el Australian Cyclist la bicicleta es utilisima para cuando hay tempestad porque constituye el mejor pararrayos, en razón á que el caoutchouc es malísimo conductor de la electricidad, y el ciclista montado sobre aquella se encuentra por tar sencillo medio aislado de la tierra. 
Por más que en España el uso de la bicicleta no se ha extendido como en otras naciones, algunos ciclistas españoles pueden, sin embargo competir con los extranjeros (1); las distancias que recorren en breve tiempo son considerables, y lo serán cada vez mayores á medida que el uso se generalice, las excursiones sean más frecuentes $y$ muy en particular si se mejora el deplorable estado de muchas de nuestras carreteras y caminos vecinales.

El velódromo ha sustituido al hipódromo y los records de los ciclistas despiertan cada dia mayor interés; pues la bicicleta además de los buenos servicios que presta para recorrer con brevedad largos trayectos, es muy conveniente para desarrollar las fuerzas musculares, y de esperar es que en lo

(I) El corredor extranjero $\mathrm{Mr}$. Smts dirigió un reto á los españoles en Agosto de 1894, por el que apostaba el honor $\delta 500$ á 1.000 pesetas para el match de 5 kilómetros: cuyo reto fué aceptado por el señor Periquet, no habiéndose llevado á efecto porque M. Smts no consignó en el plazo marcado las 1.000 pesetas convenidas como apuesta.

En las carreras verificadas en e! año siguiente en la pista de las Delicias, los afamados ciclistas señores Campo y Lacasa triunfaron sobre los corredores franceses. 
sucesivo harán uso de tan importante medio de locomoción todas las clases sociales (I).

Restablecido por el art. 40 de la ley de Presupuestos de 5 de Agosto de 1893 , el impuesto sobre los carruajes de lujo que creó el decreto de 2 de Octubre de $18 / 3$ (y que habia derogado la ley de 11 de Julio de 1877 ), la equidad aconseja adoptar igual medida respecto á las máquinas expresadas, puesto que constituyen medios de locomoción más breves, higiénicos y económicos que los mencionados carruajes de lujo; si bien deberá rebajarse proporcionalmente el tipo de imposición ó gravámen en relación al número de personas que las utilicer, y teniendo en cuenta que de las que se usan en la actualidad no puede servirse à la vez de cada una de ellas más que una sola persona.

Por los titulados carruajes de lujo (aun cuando no tengan la ostentación y las condiciones de verdadero lujo) pagan los dueños respectivos las cuotas prefijadas por el articulo 46 de la ley de 30 de Junio de 1895 , con arreglo á la base ó categoría de la población

(1) El Rey de Bélgica ha reemplazado por bicicletas los briosos caballos que hacían servicio entre su palacio de Laeken y el de Bruselas.

En la Cámara de Diputados de la expresada nación se ha habilitado una galería-colgadero para el depósito de bicicletas de los representantes que prefieren este medio de locomoción para ir á la Cámara. 
en que resida el contribuyente, y además el recargo municipal de un roo por 100 que los Ayuntamientos pueden imponer para cubrir sus atenciones, conforme á lo preceptuado en el art. 40 de la referida ley de 15 de Agosto de 1893 y en el art. $80^{\circ}$ de la instrucción provisional de $1 .{ }^{\circ}$ de Julio de 1895 ; mientras que ni los dueños de los velocípedos, ni los que se sirven de los mismos contribuyen por ningún concepto, à no ser las cuotas impuestas por algunos Ayuntamientos; y no vemos la razón del porqué se ha de privar el Estado de un ingreso, á que tiene tanto derecho, por lo menos, como los Municipios.

El número de los velocípedos es ya más considerable que los de los carruajes sujetos á impuesto, y creemos no será aventurado asegurar que aumentará mucho más en lo sucesivo, á medida que el público se persuada de la mucha utilidad que el uso de aquellos reporta y el precio de los mismos sea más reducido; pues el entusiasmo por la bicicleta es mayor cada día en todos los países civilizados, por ser un medio de locomoción higiénico y recreativo, no requiere muchos cuidados, y economiza gastos y un tiempo precioso, particularmente en los trayectos largos, pues como dice el Sr. Echegaray es un triunfo de la ciencia: un sistema de locomoción individualista como ninguno: un medio de salvar el espacio, comparable al 
de los trenes de las vias férreas, una economia de fuerzas verdaderamente admirable».

Es además necesario para organizar solaces giras ó excursiones campestres, y agradables fiestas populares, habiendo llegado á constituir un nuevo elemento de la sociedad moderna y en el que nuestros insignes dramaturgos encuentran ocasión propicia para conquistar mayor gloria y renombre con sus nuevas é inspiradas producciones, por las cuales los lindos coliseos se ven favorecidos por distinguida y numerosa concurrencia. Por tanto, nada, pues, màs lógico, equitativo y procedente que, en la denominación de los susodichos carruajes (1) y para los efectos del impuesto, se comprenda también toda clase de velocipedos que se destinen al sport, pero cuidando de guardar la relación antes indicada; y cuyo impuesto una vez establecido, habrá de prestar no despreciables rendimientos en favor del exhausto Tesoro nacional (2).

(1) Conforme á lo establecido en el art. 2.0 de la instrucción de 1.० de Julio de 1895 se consideran carruajes de lujo y por consiguiente suietos a impuesto, todos los que sirvan para la comodidad, recreo ú ostentación de sus poseedores.

(2) Según datos que hemos consultado resulta que los 149.080 velocipedos declarados en Francia en 1894 han dado al Tesoro un rendimiento de 1.501 .000 
La blasfemia.

La blasfemia, ese lenguaje impúdico y soez que constituye una ofensa grave á los más sanos principios de la moral cristiana, que degrada à los mismos que la pronuncian, y que demuestra una lamentable falta de cultura y educación social, ha llegado á extenderse tanto por todas partes, que nada más común, por desgracia, que oir a todas horas y en medio de las calles y sitios públicos, y hasta en las inmediaciones de los, templos, palabras obscenas y repugnantes blasfemias que ofenden el sentimiento religioso, escandalizan á la infancia y lastiman el pudor de las personas bien educadas.

Es, pues, necesario prohibir de una manera absoluta y terminante la blasfemia, y adoptar medidas enérgicas para reprimir ese vicio hediondo, afrenta y oprobio de toda sociedad civilizada; ese carbón encendido que abrasa los ácidos lábios de quienes la pronuncian, y hiere los oidos de todas las personas cultas que las oyen.

Por tanto, conreniente será corregir tan nefando y repugnante vicio con una multa de 10 pesetas por la primera vez, 20 por la

francos; los 198.286 en el siguiente 1.9S2.686; y lo consignado en presupuesto para 1896 por impuesto velocipédico asciende á 2.600 .000 francos. 
segunda y 30 por las sucesivas; sin perjuicio de las demás responsabilidades que procedan cuando el caso llegare á constituir un delito de los comprendidos en el Código penal.

La acción para denunciar la blasfemia será pública. Las denuncias se sustanciarán en juicio verbal de faltas, dentro de los seis dias siguientes después de presentadas, oyendo al denunciador, al Fiscal y al denunciado si asistiere, y presentando las demás pruebas que se soliciten y el Juez estime pertinentes. Cuando la sentencia sea condenatoria se impondrán las costas al acusado.

Los que resulten insolventes en el pago de estas multas, sufrirán un dia de arresto por cada 2 pesetas y 50 céntimos que dejen de satisfacer. El arresto le cumplirán en los depósitos municipales, sin opción á otro socorro, ni á otra clase de alimentos, aunque sea á sus expensas, que agua y medio kilógramo de pan por cada día; á no ser que se encontraren enfermos y el médico forense ó titular respectivo dispusiere otra cosa, por exigirlo la enfermedad ó dolencia de aquellos.

Sin perjuicio de esto, serán responsables civil y subsidiariamente de los hijos menores de edad, los padres, tutores ó encargados, los amos por sus dependientes ú obreros; los dueños de cafés, cantinas y demás establecimientos públicos, por las infracciones que se cometan dentro de éstos. 
No esperamos que por tal procedimiento habrá de cortarse radicalmente el repugnante vicio de la blasfemia, pues desgraciadamente se halla tan arraigado en nuestro pais que blasfema el jóven y el viejo; los pobres y muchos que no lo son en intereses materiales; los que carecen de principios de educación, y algunos que, habiéndolos conocido, no los observan; el jornalero y el estudiante, el que gasta blusa y aun el que gasta levita. Creemos, si, que aumentará los ingresos del Tesoro público, y que si los blasfemos solventaren todas las multas mencionadas, no haria falta otro tributo para nivelar el presupuesto del Estado. Confiamos tambien que cohibirá en gran parte, tan detestable vicio, y que habrá de contribuir á moralizar las costumbres, porque como el loco por la pena es cuerdo, algun padre de familia quizà prefiera amordazar los lábios de sus hijos antes que pagar multas y costas por ellos; lo propio que los amos por los criados; y los que no quisieren tener en sus haciendas, casas ó establecimientos personas blasfemas, ni pagar por ellas, pudieran despedirlas, y por doquiera que fueren, llevarian consigo el estigma de blasfemas.

$\mathrm{Si}$, lo que no es de esperar, se llegare por el procedimiento indicado à extirpar de raiz tan execrable vicio ¿qué máśs podriamos desear? En tan anhélado caso, como no solo de 
pan vive el hombre (I) de buen grado se perdonaría el tributo á trueque de evitarse procedimientos enojosos, y sobre todo, para ver colocada á nuestra nación no ya al nivel, la primera entre todas las del globo terráqueo en civilización y cultura, que no otra cosa significa el bien hablar, el respeto á las cosas sagradas, y la separación del castizo idioma castellano de toda palabra malsonante.

¿Qué espectáculo tan hermoso ofrecería nuestra patria el día que pudiera decirse: en España no se conoce la blasfemia!

La prensa mercantil.-Lances de honor. crímenes, suicidios.

La prensa, ese poder, al que muchos llaman Cuarto Estado, por la influencia legitima que ejerce en todas las naciones cultas, es el factor más importante para la propaganda.

Muchos son los males que en la humanidad ocasiona el sistema de información emocional puesto en moda por la prensa mercantil, porque la publicidad que facilita la prensa contribuye mucho al desarrollo de los crimenes que se cometen; y ya dijo Voltaire que la moda impera hasta en los crimenes.

Los desafios ó duelos llamados lances de honor, no son otra cosa que agresiones de

(1) Deuter, VIII.-3.

CRISIS agrícola. 
muy mal gusto que se infieren entre los que se consideran ofensor y ofendido. Más noble, meritorio y sublime es el sufrimiento y la paciencia que tanto recomendaba Platón contra las injurias, calumnias y las persecuciones injustas, ó el perdón que tanto honra y dignifica; y de no perdonar, más propio y razonable recurrir á los Tribunales de justicia en vindicación de las ofensas inferidas, que al sable ó la pistola para derramar sangre humana, causar escándalo y acudir después á la prensa á fin de que publique un suelto en los siguientes ó parecidos términos: Examinando ayer unos sables en los alrededores de Madrid los señores N. y N. en compañia de algunos amigos, tuvo el primero la desgracia de inferirse una herida en el pecho que no parece revestir gravedad.» Con lo cual queda consumado un delito y los contrincantes tan adversarios ó más que antes del duelo; y cuando quedan amigos mediante una herida de mayor ó menor gravedad, prueba este hecho que tan injusto ha sido el uno como el otro al ofenderse reciprocamente ó al admitir un desafío el que se considera honrado como el que califica de un infame (1).

(1) En Inglaterra se consideran los duelos 6 desafíos como verdaderos crímenes, y los que en aquellos toman parte son castigados con la mayor severidad. 
Lo propio decimos de los suicidios. Sólo à Dios pertenece la vida y las contrariedades de la misma, es preferible soportarlas con resignación cristiana que sustraerse á ellas por medio de un crimen como el suicidio, que tanto desdora sin que nada purifique.

El que se suicida, ya sea por la perturbación de sus facultades intelectuales que le priva de la razón y de la conciencia de sús actos en el momento de atentar contra la vida; ya por la falta de creencias religiosas, ó ya por cobardía como opina el célebre Monlau y el insigne Descuret, no merece otra cosa que el desprecio en el último caso y la consideración cristiana en los demás; como quizá también la merezca en el momento de apliacarle el rigor de la ley por el crímen cometido, el miserable que vilmente incendia, destruye ó asesina; pero nunca elogiar el mal, enaltecer al que lo haya consumado, ni detallar los medios puestos en práctica para llevarle á efecto. .

El inusitado afán de la notoriedad, desarrolla al fanatismo en los ignorantes, y los precipita en la corriente del crimen, pues alguno porque se ocupe la prensa de sus nombres y relaten sus biografias que nadie conoce, ni al público interesa, ó contagiados por las malas lecturas (que no debieran ser consentidas, puesto que no son culpables solamente los que hacen el mal, sinó también 
los que han permitido sembrar la mala semilla, y los que después de nacida, en vez de arrancarla, han tolerado su desarrollo y crecimiento) cometen los crimenes más horrendos, con lo que se consideran ya unos héroes; pues la publicidad como dice Bonafoux, es contagiosa y se trasmite como la hidrofobia.

Así lo reconoció Napoleón I cuando en 6 de Mayo de 1806 escribióá Mr. Jouche diciéndole: "Si se incurre en la necedad de seguir dando celebridad á los bandidos en periódicos y proclamas, pronto aumentará sin número con otros fanáticos estúpidos. El instinto del crimen no debe ser estimulado con el amor á la celebridad. Recomendad, pues, á los gendarmes que tiendan emboscadas á esos asesinos; pero que no canten sus éxitos con grandes victorias».

Como medida preventiva, conviene evitar la publicidad romántica de los crimenes y de los suicidios que se cometan, pues influye notoriamente, y es el gérmen prapagador de la epidemia en los corazones predispuestos al contagio del suicidio ò del crimen, é imponer por tanto en juicio de faltas una multa de 500 pesetas por la primera vez y r.000 en caso de reincidencia à los que concierten y efectúen un duelo ó desafío; sin perjuicio de las demás responsabilidades que procedan conforme al Código penal. 
En la propia multa incurrirán las personas que acudan á presenciar tales actos, bien en clase de padrinos, testigos ó espectadores, como igualmente el que incitare á otro á provocar ó aceptar un duelo, ó le demostrare por haberle rehusado.

Asi bien, incurrirá en la multa expresada todo libro, revista periódico ú hoja suelta que, de un modo más ó menos directo publique alguna noticia relativa á los duelos, crimenes y suicidios; siendo responsables del pago de estas multas los autores, y, por su insolvencia los editores ó impresores de tales publicaciones.

De todos los ingresos propuestos esperamos que el que menos rendimientos dará al Erario, es el que atañe á la prensa, teniendo en cuenta la sensatez, ilustración y patriotismo que distingue á la inmensa mayoría de los periodistas, y porque persuadidos de la noble é importante misión que deben ejercer en la sociedad, no habrán de dar lugar al menor correctivo.

\section{Insinuación de otros diversos.}

Con los ingresos anteriormente detalla- . dos abrigamos la confianza que se habrá de compensar con holgura el impuesto relativo a los vinos y además arbitrar recursos para las recompensas y propuestas; y sin perjuicio de los aumentos que pueden obtenerse y 
de que es susceptible la renta del timbre, á poco que se esmere la inspección en los diversos ramos que aquella abraza; en los beneficios que resultan de ciertas industrias: particularmente de las comprendidas en la Tarifa $2{ }^{2}$ del reglamento vigente de la contribución industrial; de los que también pueden conseguirse en el monopolio de tabacos con la reforma de labores y tarifas que de acuerdo con la Compañia arrendataria pudiera llevarse á efecto; como asi mismo en los alcoholes, aguardientes, licores y cervezas; en los bienes que constituyen el patrimonio del Estado, y de todos los demás medios ó elementos que puedan y deban aprontar su parte proporcional para levantar las cargas y servicios de la nación, indicamos, sin embargo, con la mayor brevedad, para no bacer demasiado largo este capitulo, otros diversos, por si se estimare conducente ó de aplicación práctica alguno de ellos.

Las recomendaciones, ó sea à todo el que recomiende el favorable ó adverso despacho de cualquier asunto pendiente de resolución en los Tribunales ú oficinas; y por más que suponemos sucederá lo que con la penalidad establecida en la ley Electoral que, á pesar de lo mucho que se falta á ella, rara vez es la que se aplica, y nunca al más fuerte, convendrá no obstante imponer en juicio de faltas una multa de 1.000 pesetas por la 
primera vez, 2.000 por la segunda, y 4.000 por cada una de las sucesivas que el infractor satisfará en papel de pagos al Estado, y además otra cantidad igual en efectivo metálico para el denunciante, una vez que éste justifique el hecho imputado, ya sea funcionario público ó simple particular. En el primer caso será declarado inamovible en el cargo que el funcionario denunciante desempeñe, y no podrá ser separado del mismo sino en virtud de sentencia firme en que así lo declaren los tribunales de justicia.

La loteria, (ese juego de azar ó timba nacional como muchos le denominan, y que constituye un acto tan inmoral como todo el que sea adquirir pingües ganancias en breve tiempo y con muy poco trabajo) establecida en 1763 para atender con sus productos à objetos piadosos, es hoy uno de los recursos del Erario y el tributo que se paga con mayor gusto en Epaña, á pesar de ser voluntario y de los más gravosos y perjudiciales; $y$ ya que las necesidades del Tesoro no permitan la completa supresión de aquella, con lo cual ganarian las buenas costumbres y el estimulo al ahorro y al trabajo, podria aumentarse el número de billetes, ó elevarse el descuento en los premios, pues la reforma establecida por el art. 17 de la ley de Presupuestos de 30 de Junio de 1892 , dió un aumento de 5 millones de pesetas en el 
ejercicio de $1892-93 ; y$ antes del 15 de Diciembre de cada año ya suele telegrafiar la Dirección general del Tesoro, á las Administraciones de loterias por haberse agotadc. en aquel Centro las existencias de billetes para el sorteo extraordinario titulado de Navidad.

No obstante hallase casi todas las ventajas de una parte y las desventajas de otra, el público no quiere persuadirse que el bienestar y la fortuna solo se adquieren mediante el trabajo y la economia, por cuyas vias. tan accesibles y exentas de peligros para los hombres de buena voluntad puede llegarse al mejor medio de hacer frente à cualquier enfermedad, ó á una desgracia y en las que se halla la satisfacción más íntima y halagüeña, la cual no puede existir cuando se ha ganado la victoria sin combate ú obtenido. el premio sin mereçimientos.

La supresión de las mencionadas Administraciones de loterias para que los billetes. se expendan en los estancos ó en determinados establecimientos industriales, sería más económico para la Hacienda y más cómodo para el público aficionado.

También seria más conveniente para los. intereses del Tesoro, rebajar la importancia de los premios mayores y aumentar los pequeños, pues si bien desaparecería la ilusión de obtener cuantiosas cantidades en un 
momento dado, en cambio le sustituirian con ventaja las mayores probabilidades de conseguir moderadas ganancias que demostrasen con numerosos y repetidos ejemplos los que se viesen favorecidos por la suerte, y al persuadirse el público que lo que antes era solo debido al azar ó á la casualidad, obedecía ya á un bien meditado cálculo y á una ámplia base de probabilidad.

Los perros de lijo, pues la raza canina es un peligro permanente para los pacíficos transeuntes, en particular durante la época de los fuertes calores en que la hidrofobia adquiere mayor desarrollo, ocasionando víctimas todos los años, como así lo atestiguan multitud de ejemplos; y si en algún caso constituye aquélla una defensa, también lo es un arma de fuego, y sin embargo el que tiene precisión de ella para usarla, tiene que pagar préviamente el importe de la licencia correspondiente; asi que solo exceptuariamos del impuesto los perros de que se sirven los ciegos, los pastores, y los que habitan constantemente en las casas aisladas del campo (I).

La recogida del oro, de la propia manera que lo fué la de la plata y calderilla de acuñaciones anteriores al ig de Octubre de 1868 ,

(1) El impresto establecido en Francia sobre los perros, dí al Tesoro en 1893 un ingreso de 8.700 .000 francos. 
en que se implantó el nuevo sistema monetario en harmonía con el métrico decimal; cuya circulación constituye un comercio entre los tenedores de tan codiciado metal, los cuales no hacen cambio alguno á la par, sinó que exigen premios elevados, sin que satisfagan al Erario contribución de ningún género, y los que lo tienen almacenado sin aplicación alguna, originan la escasez del expresado metal, en perjuicio de sus mismos poseedores y del comercio en general.

El absenteismo, á fin de estimular á los propietarios á labrar por sí mismos sus fincas y permanecer en ellas una gran parte del àño, como uno de los medios más efica. ces para poder introducir en el cultivo toda clase de mejoras; pues son pocos los propietarios acaudalados que hacen vida de campo, porque la mayor parte prefieren vivir en las ciudades populosas ó en la Corte entre el lujo y ostentación; separando asi à la familia de las ocupaciones campesinas y del espiritu rural necesario para sacar à la agricultura del estado de postración y abatimie to á que la conduce el absenteismo.

El celibalo, sobre el que pudierä recáer un impuesto, y á imitación del establecido en otras naciones, imponer un tributo a los que excediendo de 30 años, sin pertenecer al estado secular, permanezcan solteros, y á los viudos sin familia que no vuelvan á 
contraer matrimonio antes de cumplir la edad de 50 años.

Los matadores de animales útiles à la agricultura, pues así como perciben alguna recompensa los que matan à los animales dañinos, merecen aquéllos la imposición de una multa, aunque sea solamente de 2 á Io pesetas, según los casos y circunstancias; pero después que la primera clase de animales haya sido detallada minuciosamente en un reglamento especial y dádole la debida publicidad, à fin de que nadie pueda alegar ignorancia.

La defraudación en el peso ó en la medida, en cuyo tráfico ilicito tanto se abusa en perjuicio del público, haciendo, por tal medio, más elevados los precios de los artículos de consumo. En el pan, es generalmente el artículo en que más se abusa. La falta de un gramo ó dos solamente, pudiera dispensarse, puesto que puede consistir en que esté el pan en el horno un poco más del necesario, ó de que un añadido se agregue por equivocación involuntaria á otra pieza; más no así las faltas que exceden de 80 y 100 gramos en cada pieza de un kilógramo; y ya que el precio del pan no suele guardar relación con el del trigo, (ni el de la carne con el valor de las reses), sino que es mucho más alto, y que los vendedores no admiten ni un solo céntimo menos del precio establecido, la razón y la equidad aconsejan que el peso sea también 
justo. Por tanto, y sin perjuicio de las demás responsabilidades consignadas en el Código penal, convendrá establecer y exigir con todo rigor fuertes multas á los expendedores que defrauden en el peso ó en la medida, con pérdida en todo caso, de la mercancia en favor de los pobres ó establecimientos benéficos.

Las vias pecunrias, ó sean las intrusiones y usurpaciones de las cañadas, descansaderos, veredas y demás servidumbres de la ganadería, por las cuales deberán pagar los poseedores el valor de los terrenos usurpados, yademás la renta ó interés correspondiente al tiempo del disfrute, todo según tasación pericial y deslindes que á tal fin deberán practicarse por los datos que facilite la Asociación general de ganaderos y el Instituto geográfico y estadístico; y por cuyo medio logrará el Tesoro considerables rendimientos, ya los pagos se efectúen al contado ó bien à plazos, como se estableció para los roturadores de terrenos desamortizables no exceptuados de la venta.

\section{Advertencia ó disposición final.}

Para cubrir el déficit que resulte en los presupuestos municipales por el impuesto sobre los vinos, en su equivalencia ó compensación, los Ayuntamientos podrán utilizar el 
recargo máximo de un 100 por 100 sobre todos y cada uno de los ingresos propuestos, á excepción de los relativos á los intereses de la Deuda pública y titulos académicos, sobre los cuales no se podrá imponer recargo municipal alguno. A los que deban figurar en los repartimientos de la contribución territorial y matrículas de industrial, deberá imponerse solamente el recargo del i6 por. I00 autorizado en la actualidad sobre las cuotas del Tesoro, ó el que en lo sucesivo autoricen las leyes, sobre las referidas contribuciones.

Con el indicado objeto podrán asimismo imponer las Corporaciones municipales un recargo sobre la sal común hasta un 100 por roo sobre los derechos del Tesoro, y elevar á igual tipo de el 50 por Ioo permitido hoy sobre el valor de las cédulas personales. 

mejor solución del interesante problema agrícola, y de las que esperamos resultados provechosos, tangibles é inmediatos, confiando en la más prudente y acertada aplicación de las mismas.

No se nos oculta la serie de dificultades con que habrá de tropezarse para llevar á la práctica algunas de las reformas propuestas, pues cuando los males son crónicos y múltiples dificultan más los remedios y el tratamiento curativo tiene que ser más largo y complicado, pero que si se logra la curación aparecerá ésta más meritoria, de la propia manera que resaltará más el patriotismo, abnegación ỳ sacrificios del Gobierno y de todos los buenos españoles que logren vencer la multitud de obstáculos que se opondrán seguramente al desarrollo de los medios indicados, y al de todos los demás que fueren adecuados para conseguir el importantísimo fin apetecido.

Dificultad de harmonizar inteseses generales.

Por más que en España debe atenderse con mayor predilección à los asuntos agricolas que á todos los demás intereses, porque la inmensa mayoria de los españoles viven exclusivamente de la agricultura, no pedimos rebajas de tributos para la riqueza rústica y 
pecuaria á fin de no menoscabar la fortuna pública, ni tampoco privilegios que redunden en perjuicio de otras clases, sino la aplicación de las reformas que conceptuamos indispensables para el fomento de la agricultura y ganadería, sin olvidar el interés público, en el que deben aunarse y confundirse todos los intereses parciales.

Pero el harmonizar intereses generales es muy difícil, como lo es también harmonizar los pareceres humanos. Así lo reconocio el poderoso monarca Carlos I, en su retiro del monasterio de Yuste al pretender igualar la marcha de dos relojes, sin conseguir su deseo; comprediendo entónces lo muy difíciles que de realizar fueron sus propósitos cuando aspiraba à la monarquía universal.

Y en efecto, si á un buen rolojerole es dificil igualar la marcha de dos relojes solamente, y cuando lo consigue se desigualan al muy poco tiempo y no marcan la misma hora, no será extraño que los Gobiernos no logren harmonizar todos los intereses, ni todas las voluntades (I): sus aspiraciones

(1) Ya lo dijo el insigne Calderón de la Barca cuando a!udiendo á lo muy dificil que es la unión de pareceres exclamó:

"Busca Lisardo otros modos

si fama quieres ganar que es difícil de cortar vestido que venga á todos».

Crisis agrícola. 
tendrán que limitarse á llevar á la práctica todo aquello que estimen justo, equitativo $\mathrm{y}$ conveniente á la generalidad de los intereses del pais, en particular de los más útiles á la humanidad, de los más necesitados de protección, y de los que más contribuyen al sostenimiento de los servicios públicos; y cuando procedan de tal manera bien pueden tener su conciencia tranquila, nada debe arredrarlos y menos el temor de la critica, puesto. que según Quintiliano, el testimonio de la conciencia vale más que el de mil trigos. Pero si el mérito no está en gozar sinó en sufrir y padecer por las causas justas y simpáticas, ninguna ocasión más propicia que la actual a fin de parodiar al héroe de Villalar para decir, con propósito firme de traducir en hechos que permanezcan más indélebles que los pórfidos y bronces que, si ayer fué dia de luchar briosamente por las reformas politicas, hoy lo es de pelear con denuedo y en campos más fructiferos por la consecución de las reformas agrarias; de acudir en defensa de la agricultura, de esa fuente tan importante de nuestra riqueza pública, la más útil á la pátria, fundamento sólido de los Estados, base de la riqueza pública, y del porvenir de los pueblos, sontén de la humanidad, que hace al hombre anhelar la paz del alma, ser laborioso, amante de la tranquilidad del hogar, inclinado al orden y modesto 
en sus aspiraciones, y sin embargo se encuentra hoy muy sedienta y necesitada de protección y amparo por parte de nuestros gobernantes.

Aun cuando en España agrada mucho lo exótico, y la novedad y originalidad, hemos procurado adoptar todas las soluciones propuestas á las necesidades y conveniencias de nuestra patria; sin que tampoco abriguemos ilusión alguna por establecer nada nuevo más que lo absolutamente preciso, y de lo que esperamos lisonjeros resultados, pues demasiado sabemos que no hay nada nuevo debajo del sol; nihil novum sub sole. Tampoco se nos oculta que para llevar á la práctica algunos de los medios indicados, será necesario adoptar procedimientos enérgicos, en particular los concernientes à moralizar la Politica y la Administración, corregir errores y abusos, restablecer el imperio de la justicia y el exacto cumplimiento de las leyes, en cuyas bases se fundan todos los demás propuestos para llegar á la regeneración de nuestra abatida y agonizante agricultura y ganaderia; pues los muchos y graves males que el pais lamenta, sólo pueden ceder a grandes y poderosos remedios. Para ello es necesario acometer tan árdua y patriótica empresa sin vacilaciones y sin temor de ningún género, porque el temor del mal, según Galeno, engendra el mal; y sin ceder à ruegos, 
conveniencias ó imposiciones de políticos y amigos, porque entónces no tendría remedio lo que hoy todovia le tiene; sino única y exclusivamente a la conveniencia pública, á lo equitativo y razonable; que nucca fué cobardia ceder ante la razón ni temeridad el defecderla sin intransigencias y debilidades, posponiendo los intereses de partido al interés general, aplicando los sábios preceptos de Hipócrates uso y no abuso; evilad los excesos en todo, hasta en la sobriedad; y en algunos casos el conocido axioma in medio consistit virtus.

El Estado no debe desatender, sinó escudarse en el valioso y eficaz apoyo de las clases productoras.

La opinión pública, reina de un poder incontrastable, particularmente la opinión del país, que trabaja, produce, paga, fomenta $y$ engrandece los intereses públicos, no habrá de escatimar su más firme y valioso apoyo al Gobierno, que se proponga llevar á la práctica los medios propuestos y todos los demás que fueren conducente para mejorar la aflictiva situación de la agricultura, pues las grandes evoluciones sociológicas, siempre se han apoyado en el concurso de los pueblos, acosados por idénticas necesidades, $y$ por el deseo legitimo del mayor bienestar 
posible; y el bienestar moral y material de nuestra nación debe medirse principalmente por el progreso y desarrollo de su agricultura, cuyo malestar es cada dia más hondo y alarmente, del cual también se resiente la industria y el comercio; por lo cual el Gobierno no debe desatender, sinó escudarse en el valioso y eficaz apoyo de las clases agricolas, y aún adelantarse á sus deseos. El sábio Cardenal Cisneros no habria podido decir á los nobles la famosa frase: He ahi mis poderes, si detrás de los cañones y soldados que tenia à su servicio, no hubiese contado además con el apoyo decidido del pueblo español, dispuesto a secundarle y sostenerle en sus sanos propósitos.

\section{El fomento de la riqueza agrícola} y pecuaria, origina el de todos los intereses morales y materiales del país.

El Gobierno que se dedique con verdadero afán al fomento de los intereses agrarios, grandemente comprometidos y necesitados de remedios, alcanzará gratitud eterna y gloria imperecedera; conquistará la diadema de la inmortalidad, y el mejor galardón y la más preciosa corona que puede ceñir la frente de un Gobjerno; hará renacer la esperanza en el corazón de todos los buenos españoles, por ser el mejor legado que 
puede trasmitirles, y borrará en las cristalinas aguas del Jordán las caóticas huellas de pasados errores.

Todo esto podrá parecer á alguien un sueño, una ligera nubecilla que se disipará al contacto de la realidad, ó que es vana ilusión y quimérica esperanza nuestra; pero tenemos la convicción que si se logra implantar las reformas propuestas y cualquier otra conducente para salvar los intereses generales de la nación, habremos de tocar en breve los resultados, y aun cuando solo se apliquen en parte ó paulatinamente, creemos dará ocasión para confirmar una vez más el aforismo hipocrático lo que empezando alivia, continuando sana.

"Jamás debe olvidarse que cuanto se haga en pro de la clase agricola, ha de redundar en beneficio de la generalidad, y ha de contribuir al aumento de la riqueza y prosperidad de todo el pueblo (I).

No por eso tendrán completo remedio todos nuestros males, aún cuando en todo caso se excogite lo útil de lo perjudicial, lo quimérico de lo práctico; como el individuo que observe un severo régimen higiénico, tampoco por eso estará exento de dolencias, porque el dolor humano nunca perece; y del propio modo que al Gobierno y á cuantos se

(I) Aragó. (Diccionario enciclopédico citado T. I). 
sacrifiquen en aras del pais no habrán de faltarle ingratitudes y aún detractores, como nunca han faltado á toda obra é idea redentora, pues las grandes ideas han tenido siempre sus contrariedades al principio. La historia con su pluma inexorable y con su imparcialidad asi nos lo demuestra en todas sus páginas. Buen ejemplo tenemos en el inmortal Colón, tratado de loco y visionario; y cuando después de muchos sinsabores, ultrajes y penalidades ofrece un nuevo mundo, en premio á su talento, en recompensa al valiosísimo servicio prestado à la humanidad, particularmente à España, se le aprisiona con fuertes cadenas, confíscansele sus bienes y muere en el mayor olvido, pobre, necesitado y calumniado, imitando en paciencia y mansedumbre al santo Job. Pero el tiempo marcha, y en su vertiginosa carrera (aun cuando en muchos casos nos parezca lenta) descubre todos los secretos de lo pasado, y entónces la historia ensalza á los mártires del progreso, como ensalza también á los que se sacrifican por el bien público, no tardando la opinión en pronunciarse en favor de aquedlos que han pasado por el crisol de amarguras y duras pruebas, y de reconocer que la adversidad fué siempre alta escuela de virtud.

Triste debe ser para el ciego de nacimiento no poder apreciar las inmensas ventajas 
de la luz, distinguir las personas de su cariño, el suelo que pisa, las viandas que le sirven de alimento, las vestiduras que cubren su cuerpo, ni los objetos que le rodean; pero. indudablemente debe ser mucho más triste aún para el que tenía buena vista, y por excesos ó descuidos ha perdido tan importante sentido, sin que logre recuperarle. El primero como no ha conocido el bienestar que proporciona la vista no tendrá tantos deseos de poseerla; más no así el segundo. que no podra menos de acordarse á cada paso y en todo momento de la comodidad y. bienestar que antes disfrutaba; porque el bien no suele ser muy conucido, sinó hasta después que se ha perdido.

Pues en este último caso preciso es reconocer que nos hallamos los españoles; porque de aquel antiguo esplendor, de aquel inmenso poderio, cuyas conquistas y cuyos triunfos llegaron $\dot{a}$ donde alcanzaban las lanzas cordobesas; de aquella gloriosa nación àrbitra. de los destinos de Europa y dueña de las. Américas, en cuyos dominios no se ocultaba jamás la luz solar ¿qué nos queda? Los recuerdos de aquellos más felices tiempos; pero el pueblo español, que es tanto más enérgico cuando aparece más abatido, y que no inclina su frente a las circunstancias. más difíciles y azarosas, conserva aún incólumes la fé, la abnegación, el entusiasmo y el 
patriotismodesus mayores parı reconquistar palmo á palmo ya que nolos territorios que poseia, sus antiguos laureles, la justicia y la gloria à que es acreedor; porque la pátria heróica, la pátria predilecta, la gloriosa nación española, la cuna de los A!funsos, Fernandos, Cárlos y Felipes, de Columela, Cisneros, Herrera, Jovellanos, Ensenada y Campomanes, y de muchos génios, màrtires, héroes é hijos ilustres ni puede, ni debe perecer; y si de los escarmentados nacen los avisados, nuestras pasadas glorias, nunca por nadie igualadas, más que para envanecernos en ellas, deben servirnos para pensar en el porvenir y proceder en todo con la mayor previsión, sin olvidar que las convalecencias de enfermedades graves suelen ser largas y penosas, y que el menor descuido puede ocasionar recaidas de consecuencias fatales.

Otras muchas reflexiones pudiéramos exponer, las cuales omitimos en obsequio à la brevedad, y porque demostrado queda (como asi suponemos que está reconocido por todos), que la agricultura es la base del progreso moral y material de las naciones, principalmente de la nuestra en que la casi totalidad de sus moradores se dedican al cultivo de los campos, y que cuandoaquella prospera, el comercio y la industria se desarrollan prodigiosamente. 
Por tanto; creemos no se nos tachará de optimistas porque abriguemos una esperanza consoladora, si nuestros gobernantes y demás hombres de valia dedican su atención preferente al fomento de los intereses agricolas y pecuarios, y veamos en el desarrollo y prosperidad de la agricultura y en el de las reformas indicadas, el progreso y bienestar de todas las clases sociales; el crepúsculo matutino que sigue á la tenebrosa noche para anunciar el sol de venturoso dia; la palanca poderosa anhelada por Arquimedes que remueva los grandes obstáculos que se oponen al engrandecimiento de nuestra pátria; el apostolado de la buena nueva, el faro luminoso, la antorcha radiante, el astro refulgente en el que brillará el sol de nuestra redención, para que á la diáfana luz de sus purísimos destellos podamos lograr que nuestra querida España sea una de las naciones más prósperas y felices del mundo.

No es que vayamos á tener por eso la felicidad consumada, ni tampoco grandes territorios y dominios, pero lograremos siquiera una administración esencialmente moraliza. dora; una política subordinada á la administración; unos presupuestos verdad; crédito firme; exacto cumplimiento de las leyes; respeto à la propiedad; verdadera equidad tributaria con la cual se evitarán privilegios absurdos, desigualdades irritantes y notorias 
injusticias; órden, necesario para el desarrollo de la riqueza pública y bienestar de los pueblos; trabajo, preciado venero, fuente de prosperidad y grandeza; paz, colmo de todo bien, sin la cual no fructifica el trabajo; y que el progreso moral forme base del progreso material. Además, la clase obrera hallará ocupación constante debidamente remunerada; florecerán las ciencias y las artes, la industria $\mathrm{y}$ el comercio, y muy en particular la abatida riqueza agraria: se remediarán por último, ó al menos aliviarán en gran parte, muchos de los hondos y graves males que el pais lamenta, y muy particularmente la pavorosa y trascendental crisis que hoy sufre la riqueza agrícola y pecuaria. 



\section{INDIGE.}

INTRODUCCION.

Páginas.

1. Causas de la crisis agraria.-Esta requiere remedios eficaces y urgentes.. xIV

2. Deberes que la pátria impone á todos sus hijos.. . . . . . . . . $x \nabla \mathrm{I}$

PARTE PRIMERA.

Medios generales.

CAP. I. Importancia capital del problema agricola.. . . . . . . . 1

I. Las naciones más florecientes son las que más protección dispensan á la agricultura. . . . . . 5

2. En España se ha llegado al summum de los derechos políticos.-Los problemas agrícolas son los que requieren mayor interés y el concurso de todos los buenos españoles. . . . . . . . 8

CAP. II. La buena Administración pública. I3

1. En qué consiste. . . . . . I6

2. Ha de ser extensiva á la Provincia

y Municipio. . . . . . 20 Recompensa que merece. . . . 26 
CAP. III. Deberes reciprocos entre gobernantes y gobernados.. . . . . 29

I. Derechos y deberes. . . . . 29

2. Los tributos son una consecuencia de la necesidad del Estado. . . 33

3. Deberes de las clases productoras. . 37

4. Lamentable ligereza ó parcialidad al juzgar los actos de los Gobiernos. • • . . . • • $4 \mathrm{I}$

5. Acción que incumbe al Estado. . . 45 Verdadera clase para la mejor solución del tema. . . . . 68

CAP. IV. La enseñanza agricola. . . • . 77

I. Ventajas de la ciencia.. . . . 78

A la ciencia debemos los inventos y las comodidades que disfrutamos. . . . . . • . $8 \mathrm{r}$

2. La ley de enseñanza agrícola.--Debe exigirse el cumplimiento de la misma.-Las conferencias dominicales. . . . , . . 89

La propaganda agrícola. . . . 92

3. La enseñanza primaria.-Debe hacerse obligatoria._Una medida sencilla que pudiera dar resultados.

4. Error funestísimo de muchos labradores. . . . . . . . . 97

La vida en el campo. . . . . 99

Acción que conviene ejercite el estado.

CAP. V. Los Tratados de comercio y los Cambios. . . . . . . 105 
Pág.

I. La cuestión arancelarìa es un factor esencial para la mejor solución del interesante problema agrícola. 105

2. La protección racional es un medio necesario para el fomento de los intereses nacionales. . . . 1 10

Es así mismo necesaria para harmonizar el capital y el trabajo. . Irg

3. Los cambios internacionales. . 123

El régimen arancelario es el mejor correctivo de los cambios. . . - 127

CAP. VI. De la contribución Territorial. - 135

I. Necesidad apremiante de rectificar los amillaramientos actuales. .

2. Diversos medios de ocultar riqueza. - Desigualdades irritantes en la tributación.-El catastro. . . .

3. Las cartillas evaluatorias.-Cómo y quiénes deben formarlas. . . 150

4. Comisiones especiales para efcctuar la calificación de cultivos y la clasificación de fincas. . . . 153 Reformas indispensables. . . 155

5. Las heladas y las sequías deben ser consideradas comocalamidad para obtener el perdón de la contribución Territorial. . . . . 158

6. Conveniencia de una Caja nacional de calamidades. . . . . . . 162

$\mathrm{C}_{\mathrm{AP}}$. VII. Asociación de las clases productoras.

I. Necesidad de una bien entendida asociación agraria. . . . . . 172 
2. La vida del labrador. . . . . $\frac{\text { Pág. }}{\mathbf{I} 8 \mathrm{I}}$ El vinicultor. . . . . . . . . rgr

3. El Partido Nacional Agrícola. . . 197 Quiénes deben constituirle. . . $20 \mathrm{r}$

Fines elevados del mismo. . . . 207

4. Conveniencia de su organización inmediata para obtener las reformas que tanto interesan á las fuerzas productoras. . . . 2 ro

5. Al gran partido corresponde designar los que hayan de representarle en el Parlamento. . . . 217 Disposición transitotia. . . . 234

\section{PARTE SEGUNDA.}

\section{Medios particular'es.}

CAF. I. La riqueza vinicola. . . . . 236

I. La aflictiva situación porque atraviesa la riqueza vinícola, requiere urgentes y eficaces remedios.. • 238

2. El exceso de producción vinícola origina en primer lugar la grave crisis porque atraviesa tan importante riqueza.. . . • . . 242

Error lamentable de muchos viticultores.. . . . . . . . 243

3. Para facilitar el consumo y venta del vino es necesario elaborar buenas clases.--Los vinicultores deben atender más á la calidad 


\section{Pág.}

que á la cantidad, por ser más difícil vender que producir.-Primas á los que elaboren -buenas clases de vinos. . . . . . $2 f^{6}$

4. La escandalosa fabricación de vinos artificiales y la adulteración de los naturales hacen aumentar el exceso de producción y disminuir el consumo.--Penas severas á los fabricantes y expendedores de vinos artificiales ó adulterados. . . . . . . . 250

5. Conveniencia de acrecentar el consumo interior en España.-Medios eficaces para ello. . . . 254

6. Mercados extranjeros. - Apesar de los medios propuestos, es de necesidad, por ahora, abrir nuevos mercados y consolidar los antiguos.-Sitios á tal fin indicados. Primas á los que exporten vinos en proporción á la cantidad y clase del producto.-Sindicatos de exportación, estaciones enotécnicas, agencias consulares y exposiciones. . . . . . 279

CAP. 11. De los cereales y sus harinas. . . 291

1. El cultivo de cereales es insustituible $y$ el que ofrece más seguro porvenir. . . . . . . 292

2. El aumento en la producción de cereales es un factor importante para que los productos puedan

Crisis agrígola. 



\section{ERRATAS MÁS NOTABLES}

Páginas. Linea.

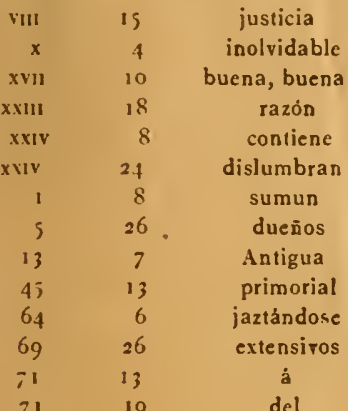

Dice.

$84 \quad 6$

$84 \quad 13$

$8-$

106

125

126

130

133

172

205

229

230

245

285

345

382

421

489

491

499

so4 asi la física

con vertiginosa

utilizan

otorguen

regula

el

mandarlas

persecución

sueltas

el

provincial

ejecutiro

3 ños

se paga en otras

suscrita

$\sin$

alconesazores

apliacarle

demostrare

de el

trigos
Debe decir.

ficticia

indomable

buena fe

sazón

continuo

vislumbran

summum

đuอก๊o

Ambigua

primordial

jactándose

extensivo

al

a)

la fisica

con la vertiginosa

se utilizan

se otorguen

regulan

él

mandarlos

persuasiỏa

nuevas

al

provisional

equitativo

lustros

pagan otras

sucinta

sino

alcones, azores

aplicarle

denostare

el de

testigos 


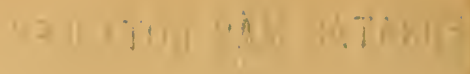
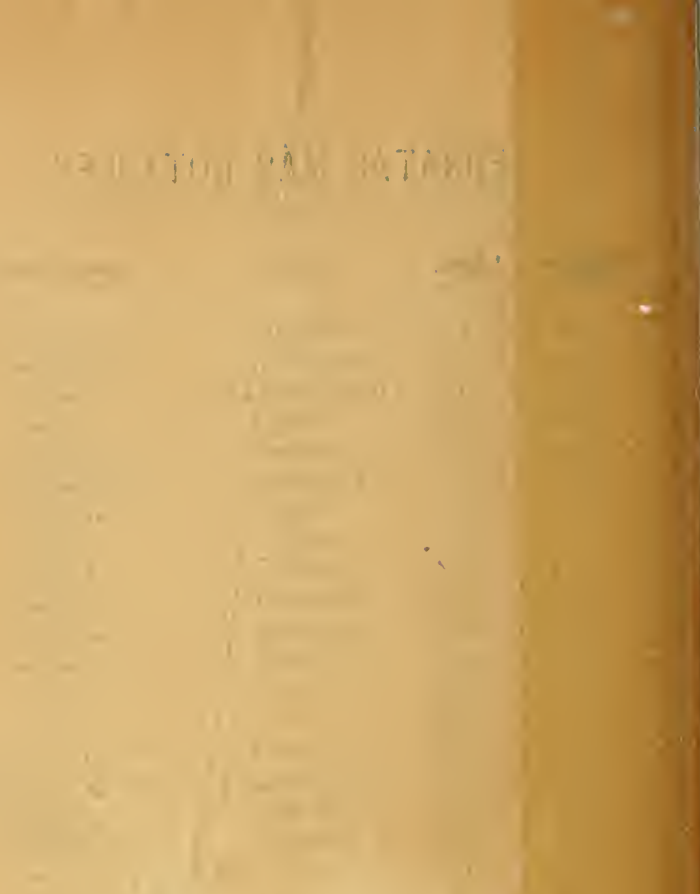


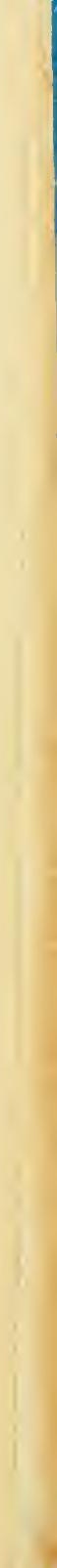



Kartinez liaroto, Santiago pecuaria en Espana $\mathrm{y}$ sus verdaderos remedios

\author{
PLEASE DO NOT REMOVE
}

CARDS OR SLIPS FROM THIS POCKET

UNIVERSITY OF TORONTO LIBRARY 
